POLONIA UNIVERSITY IN CZESTOCHOWA CHERKASY STATE TECHNOLOGICAL UNIVERSITY

KRYVYJ RIH ECONOMIC INSTITUTE OF KYIV NATIONAL ECONOMIC UNIVERSITY NAMED AFTER VADYM HETMAN

\title{
GLOBAL PARTNERSHIP FOR LOCAL SUSTAINABLE DEVELOPMENT: MODERN TRENDS AND BEST PRACTICES
}


АКАДЕМІЯ ПОЛОНІЙНА В ЧЕНСТОХОВІ

ЧЕРКАСЬКИЙ ДЕРЖАВНИЙ ТЕХНОЛОГІЧНИЙ УНІВЕРСИТЕТ КРИВОРІЗЬКИЙ ЕКОНОМІЧНИЙ ІНСТИТУТ ДВНЗ «КИЇВСЬКИЙ НАЦІОНАЛЬНИЙ ЕКОНОМІЧНИЙ УНІВЕРСИТЕТ ІМЕНІ ВАДИМА ГЕТЬМАНА»

\section{ГЛОБАЛЬНЕ ПАРТНЕРСТВО ДЛЯ МІСЦЕВОГО СТАЛОГО РОЗВИТКУ: СУЧАСНІ ТРЕНДИ ТА КРАЩІ ПРАКТИКИ}


BBC 65.04:65.5

G 54

\section{Reviewers:}

A. O. Khodjayan, Doctor of Economics, Professor, Professor of the International Economic Relations Department, Kyiv National Trade and Economic University;

I. M. Budnikevich, Doctor of Economics, Professor, Head of the Marketing, Innovation and Regional Development Department Chernivtsi National University of Yuri Fedkovich.

The team of authors: Dr., Professor L. O. Petkova; Dr., Professor A. I. Boyko; Dr., Professor V. Ya. Galchenko; Dr., Professor I. G. Goncharenko; Dr., Professor O. V. Kolomytseva; Dr., Professor V. V. Kulishov; Dr., Professor V. I. Kunchenko-Harchenko; Dr., Professor I. P. Vasylchuk; Ph. D., Professor O. Yu. Berezina; Ph. D., Professor O. M. Khomenko; Ph. D., Associate Professor O. O. Grigor; Ph. D., Associate Professor V. O. Vedeneev; Ph. D., Associate Professor I. G. Egorova; Ph. D., Associate Professor Ya. O. Izmaylov; Ph. D., Associate Professor M. M. Leshchenko; Ph. D., Associate Professor Yu. G. Makarenko; Ph. D., Associate Professor V. M. Pasenko; Ph. D., Associate Professor K. V. Slusarenko; Ph. D., Associate Professor Yu. V. Tkachenko; Ph. D., Associate Professor R. V. Trembovetska; Ph. D., Associate Professor Yu. V. Vdovychenko; Ph. D., Associate Professor N. V. Zagoruiko; Professor Kala; Ph. D. Ya. O. Kovalchuk; Prof. Ph.D. Andrzej Kryński; Ph. D., Associate Professor I. I. Maksimova; Ph. D. D. Yu. Marushchak; Ph. D., Associate Professor G. V. Puriy; Ph. D. V. V. Tychkov; Yu. S. Kulik; M. V. Ryabokon; Y. V. Pikalov; Ye. V. Shatalov; MA Jowita Ziołek-Barczak.

Recommended for publication by the Scientific Council of Cherkasy State Technological University (protocol No. 12, $18^{\text {th }}$ June, 2018).

Global Partnership for Local Sustainable Development: Modern Trends and Best Practices: monograph / [ed. by L. O Petkova, O. Yu. Berezina, Andrzej Kryński] Czestochowa, 2018. - 207 p.

The collective monograph covers theoretical and methodological ideas and practical experience of the global partnership for local sustainable development, as well as best practices for solving sustainable development problems at the local, regional and global levels and practical recommendations for the balanced implementation of all components of sustainable development.

The publication is available in the online version on: main.nuife.org/en/educator. The publication is assigned a DOI number: dx.doi.org/10.23856/W1708

(C) The team of authors, 2018

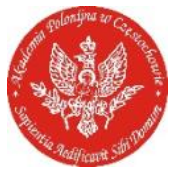

"Educator" Wydawnictwo Akademii Polonijnej

ul.Pułaskiego 4/6 42-200 Częstochowa

tel: +48343684215, fax +48343249662

www.pnap.ap.edu.pl e-mail:wydawnictwo@ap.edu.pl 


\section{ББК 65.04:65.5}

Г 54

\section{Рецензенти:}

А. О. Ходжаян, д.е.н., проф., професор кафедри міжнародних економічних відносин, Київський національний торговельно-економічний університет;

І. М. Буднікевич, д.е.н., проф., завідувач кафедри маркетингу, інновацій та регіонального розвитку, Чернівецький національний університет імені Юрія Федьковича.

Авторський колектив: д. е. н., проф. Л. О. Петкова; д. ф. н., проф. А. І. Бойко; д. е. н., доц. І І. П. Васильчук; д. т. н., проф. В. Я. Гальченко; д. н. держ. упр., проф. I. Г. Гончаренко; д. е. н., проф. О.В.Коломицева;заслужений працівник освіти України, д. пед. н., к. е. н., проф. В. В. Кулішов; д.т.н., проф. В. І. Кунченко-Харченко; к. е. н., проф. О. Ю. Березіна; к. х. н., проф. О. М. Хоменко; к. н. держ. упр., доц. О. О. Григор; к. п. н., доц. В. О. Веденєєв;к. е. н., доц. Ю. В. Вдовиченко; к. е. н., доц. І. Г. Єгорова; к. е. н., доц. Я. О. Ізмайлов; к. б. н., доц. Н. В. Загоруйко; к. е. н., доц. М.М. Лещенко; к. філол. н., доц. Ю. Г. Макаренко; к. е. н., доц. В. М. Пасенко; к. е. н., доц. К. В. Слюсаренко; к. е. н., доц. Ю. В. Ткаченко; к. т. н., доц. Р. В. Трембовецька; проф. Кала; к. е. н. Я. О. Ковальчук; проф. Анджей Кринські; к. е.н. І.І.Максимова; к.е.н.Д.Ю.Марущак; к. е. н. Г.В.Пурій, к. т. н. В.В.Тичков; Ю. С. Кулик; М. В.Рябоконь; Ю. В. Пікалов; С. В. Шаталов; МА Йовита Зелок-Барчак.

Рекомендовано до друку Вченою радою Черкаського державного технологічного університету (протокол № 12 від 18 червня 2018 р.).

Глобальне партнерство для місцевого сталого розвитку: сучасні тренди та кращі практики: монографія / [за заг. ред. Л.О. Петкової, О.Ю. Березіної, Анджей Кринські] - Ченстохова, 2018. - 207 с.

У колективній монографії висвітлено теоретико-методологічні ідеї та практичний досвід глобального партнерства для місцевого сталого розвитку, кращі практики вирішення проблем сталого розвитку на локальному, регіональному та глобальному рівнях, практичні рекомендації щодо збалансованої реалізації всіх компонент сталого розвитку.

Рукопис доступний в онлайн-версії за адресою main.nuife.org/en/educator. Рукопису присвоєно номер DOI: dx.doi.org/10.23856/W1708

(C) The team of authors, 2018

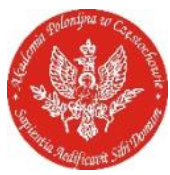

"Educator" Wydawnictwo Akademii Polonijnej

ul.Pułaskiego 4/6 42-200 Częstochowa

tel: +48 3436842 15, fax +48343249662

www.pnap.ap.edu.pl e-mail: wydawnictwo@ap.edu.pl 


\section{CONTENT}

Chapter 1. Interregional cooperation and cross-border partnership for sustainable development

1.1. Conceptual platform for global partnership and sustainable development 10

1.2. Global partnership: trans-border dimension $\quad 23$

1.3. Financial unity as the framework for global partnership 36

1.4. European experience of interregional cooperation and cross-border partnership 42

Chapter 2. Decentralization and territorial consolidation in Ukraine as new trends in global partnership

2.1. Global partnership for local economic development

2.2. Decentralization in the system of prerequisites for sustainable economic growth:

European experience for Ukraine

2.3. Policy of socio-economic development of Ukrainian regions under the conditions of decentralization

2.4. Decentralization reform in Ukraine: regulatory and organizational aspects

74

2.5. Interim results and consequences of decentralization reform: the regional experience

Chapter 3. Social and humanitarian content of the global partnership for local sustainable development

3.1. A mass consumption society in the context of sustainable development 89

3.2. Social-integrative paradigm of global partnership

3.3. Information challenges for sustainable development in the context of forming international competitiveness

3.4. Local community safety and global security policy

Chapter 4. Global partnership in action: implementation of international projects in Ukraine

4.1. Features of interregional interaction in the context of implementation of international projects

4.2. Horizons of implementation of the successful practicesof capital mobilization

4.3. Approaches in positioning of international institutions of startup acceleration and incubation

4.4. Evaluation of the effectiveness of phases I and II of the EU / UNDP Project

"Community Based Approach for Local Development": the regional interpretation

4.5. Sustainable development of communities on the basis of global partnership: evaluation of the results of phase III of the EU / UNDP project "Community Based Approach to Local Development"

Chapter 5. Environmental, Energy and Innovation Components of the Global Partnership for Sustainable Development

5.1. Technical and technological bases for achieving environmental safety of sustainable development 
5.2. International competitiveness of secondary mineral resources due to globalization of ecological and economic problems

5.3. Environmental aspects of the energy component for the sustainable development of Ukraine's regions

5.4. Financial and integrated reporting as a tool for displaying information about the results of investment and innovation development of enterprises in the national and global business environment 
Розділ 1. Міжрегіональна кооперація та транскордонне співробітництво для сталого розвитку

1.1 Концептуальна платформа глобального партнерства та сталого розвитку 10

1.2. Глобальне партнерство: транскордонний вимір

1.3. Фінансова єдність як рамкова умова глобального партнерства

1.4. Європейський досвід міжрегіональної кооперації та транскордонного

співробітництва

\section{Розділ 2. Децентралізація і територіальна консолідація в Україні як новітні} тренди глобального партнерства

2.1. Глобальне партнерство для сталого місцевого розвитку

2.2. Децентралізація в системі передумов стійкого економічного зростання: європейський досвід для України

2.3. Політика соціально-економічного розвитку регіонів України в умовах децентралізації

66

2.4. Реформа децентралізації в Україні: нормативно-правове та організаційне

забезпечення

2.5. Проміжні результати та наслідки реформи децентралізації: регіональний досвід

Розділ 3. Соціально-гуманітарний контент глобального партнерства для місцевого сталого розвитку

3.1. Суспільство масового споживання в контексті проблем сталого розвитку 89

3.2. Соціально-інтеграційна парадигма глобального партнерства

3.3. Інформаційні виклики сталого розвитку в контексті формування міжнародної конкурентоспроможності

3.4. Безпека локальних територіальних громад та глобальна політика безпеки

Розділ 4. Глобальне партнерство в дії: реалізація міжнародних проектів в Україні

4.1. Особливості міжрегіональної взаємодії в контексті реалізації міжнародних проектів

4.2. Горизонти імплементації успішних практик мобілізації капіталу

4.3. Підходи до позиціонування міжнародних інституцій 3 прискорення та інкубації стартапів

4.4. Оцінка результативності I та II фази Проекту СС/ПРООН «Місцевий розвиток, орієнтований на громаду»: регіональний розріз

4.5 Сталий розвиток громад на засадах глобального партнерства: оцінка результатів III Фази Проекту СС/ПРООН «Місцевий розвиток, орієнтований на громаду» 
Розділ 5. Екологічна, енергетична та інноваційна компоненти глобального партнерства для сталого розвитку

5.1. Техніко-технологічні засади забезпечення безпеки навколишнього середовища та сталого розвитку

5.2. Міжнародна конкурентоспроможність вторинних мінеральних ресурсів в умовах глобалізації екологічних та економічних проблем

5.3. Екологічні аспекти енергетичної компоненти для сталого розвитку регіонів України

5.4. Фінансова та інтегрована звітність як інструмент відображення інформації про результати інвестиційно-інноваційного розвитку підприємств в національному та глобальному бізнес-середовищі

Колектив авторів 


\section{INTRODUCTION}

Global economic growth stipulates the unity of economic, environmental and social aspects of the world economy development. A growing understanding and deepening of the implementation policy of Global sustainable development goals have become widespread. The role of science, technology and innovation are the main tools for the implementation of a new agenda for global development since they can enhance the efficiency in both economic and environmental components of development, invent novel and more comfortable satisfaction of human needs, the empowerment of people in their own future.

The inter-state and inter-regional changes are intensifying, which requires new approaches to the integration and cooperation on the basis of the global partnership concept. The decentralization reform in Ukraine contributes to the modernization of public administration, effective local governance, extensive engagement of a civil society in the monitoring and direct participation in the implementation of the state socio-economic policy.

The issue of global partnership, implementation of this concept in public policy for the sustainable development of regions of Ukraine has long been topical in scientific studies. Civil society institutions, and above all, international organizations, educational and research establishments play a key role in the development and implementation of mechanisms and instruments of the global partnership for the sustainable social development.

The monographers consider various aspects of the global partnership to enhance local sustainable development, necessary conditions to improve the level and quality of life in the society, the strengthening of international competitiveness of the country's economy and its regions. The monograph is aimed at sharing the results of scientific findings about modern trends in global partnerships and opportunities and prospects for replication of best practices for the sustainable development of the society. 


\title{
CHAPTER 1
}

\section{INTERREGIONAL COOPERATION AND CROSS-BORDER PARTNERSHIP FOR SUSTAINABLE DEVELOPMENT}

\subsection{CONCEPTUAL PLATFORM OF THE GLOBAL PARTNERSHIP AND SUSTAINABLE DEVELOPMENT}

\author{
Yuliia Tkachenko \\ PhD (Economics), Associate Professor, \\ Associate Professorof the Finance Department, \\ Cherkasy State Technological University, Cherkasy, Ukraine
}

Global shifts in the legal, institutional, structural, financial, technological, communication conditions of the international labor division have strengthened the role of local factors in the development of the world community and increase of the dynamism of the regionalization process in the world economy. The regionalization in terms of its content and results transforms in a new form of "localization", which involves separate national territories in the process of globalization.

Subjects of economic regionalization in the modern world economy are not only the countries included in the various territorial associations and their subsystems, the regional economic integration of the national economy and the regions within the country.

Now the attraction of the country's regions in integration processes has become a critical factor stimulating socio-economic development through free movement of goods, services, capital, technology, and labor between the internal and external markets. The increasing economic interconnectedness of the country's regions with foreign regions and the elaboration of interregional cooperation are due to the need for the development of new, more flexible forms of relationships.

The ratio of globalization and regionalization processes in the world economy by various schools is ambiguous, which indicates the complexity of understanding of the nature and content of the process of regionalization in the world economy.

There are several points of view on the processes of globalization and regionalization. The first involves their opposition, the second one is based on parallelism, however, the modern scientific school implies the understanding of these two processes: globalization and regionalization as two complementary characteristics of a single, comprehensive process of the global partnership.

In this context the study of the categories of "globalization", "regionalization", "integration", their relationship, identification of the forms and levels of regionalization in the world economy, understanding the essence of concepts "region", "international region", "border region", "cross-border region" become of particular importance from the point of view of scientific knowledge.

When defining globalization in the context of the research logic, in our opinion, the most comprehensive approach is according to which the globalization is a systematic process of qualitative changes of the world economy, which is formed on the basis of internationalization of economic life, liberalization of foreign economic relations of most countries of the world, intensification of the processes of regional economic integration, transnationalization of capital and production, the harmonization of rules of world economic 
engagement, resulting in the creation of global markets for goods, services, factors of production on the basis of common information, infrastructure, and institutional platforms.

In this formulation, internationalization, liberalization, transnationalization are the background and modern elements of globalization of the world economy (transformation subsystem). Thus, in particular, the internationalization of the economic system of a country is determined by the tendency of the intersection of national reproduction processes, now covering all stages of production, distribution, exchange and consumption, which leads to the creation of global markets for factors and results of production.

Liberalization of foreign economic relations implies an increase in the degree of openness of national economic systems to both internal and external participants of world economic relations, creates favorable conditions for the functioning of global markets.

Transnationalization of the capital leads to the creation of a globalized production, which involves the formation of a single world financial and economic system and the process to efficiently move capital to stimulate less developed areas and countries as a whole and reduce the spatial imbalances in the world.

Regional economic integration, in our opinion, is a part of the larger system process that is regionalization.

One of the most prominent representatives of the institutionalism and a new institutionalism in the western science is Guy Peters (Peters, 1998). In his work "The New Institutionalism in Political Science" differences between "old" and "new" institutsionalism, indicators and main characteristics of neo-institutionalism are analyzed. James March and Johan Olsen have given impetus and formed the basic tenets of the "new institutionalism" (March and Olsen, 1984). In political work "American Political Science Review" (March and Olsen, 1984) they justify that the development of society depends not only on the state of the economy, the existing social conditions, but also from the "composition of political institutions", which have a certain level of autonomy (March and Olsen, 1996).

The institutionalists believe that the process of regionalization is determined by the limits of political institutions, the effectiveness of which is limited by the complexity of the organizational environment, which is formed by a large number of actors (agents), including authorities and management (different hierarchical levels), economic agents (subjects financial, economic and business relations), public and non-governmental organizations. At the same time, according to D. North, institutions tend "to strengthen their positions for survival in the context of widespread resource constraints and competition and, accordingly, can obtain certain benefits from potential exchange"(North, 2005). In this approach, the main objectives of regionalization are: reduction in transaction costs; formation of a system of mutual guarantees for all participants; creation of favorable conditions and benefits for participation in the integration process.

Institutionalism has an important practical value in the framework of regional integration groupings. In the same context the process of regionalization as the one of economic integration of states and their amalgamation into blocks (groups) according to the criterion of geographical proximity and the commonality of material, financial and commercial interests is considered by the neo-marxists.

The concept of "peaceful coexistence", which remains popular in contemporary international politics is characteristic for neo-Marxism. As Kryvets (2004) indicated, it was first proposed in the early 20-ies at the Genoa conference, by Soviet Russia and was manifested in the Rapallsky Peace Treaty of the bolsheviks with Weimar Germany on April, 16, 1921. Based on some concepts of classical Marxism, neo-marxists, in particular, Wallerstein (2005) depicts the space of international relations in a form of a global empire, 
the periphery of which remains under the dominance of the center even after gaining of independence by colonial states.

According to neo-marxist approach (Wallerstein, 2005) the formation of such groups is the reaction of participants to the challenges and threats of globalization and consequently leads to the fragmentation of the global economic space and enhancing the competition between the organized regional blocs.

Functionalism is directed against the destructive selfishness of the states and is based on the fact that conflicts and wars are not a characteristic human trait (D. Mitrani, B. Russell, G. Wells, et al.). Functionalists consider "region building" to be the basic concept. In their view, the regionalization process is passive, but "region building" involves active purposeful actions of state and non-state actors for the development of the spatial environment. Powerful "poles" of the integration structures are formed on the territories, which "blur the boundaries of state borders". According to functionalists, a social development and configuration of major business processes have to determine not state borders but common interests.

Functionalists and neo-functionalists (Mykoliuk, 2012) emphasize the fact that the integration should start from the individual sectors of the economy, creating general governing bodies which obtain a part of national sovereignty in the relevant field/

Integration centers arise when combining cultural, ethnic and religious views and with the availability of resources (institutional, organizational, informational, intellectual, financial, etc.) in compliance with the principle of political solidarity.

The researchers of postmodernism such as A. Toynbee, A. Etzioni, G. Inglehart, J.-F. Liotard, C. Jenks, Of. Bauman, D. Bell, M. Heideger, Gab Hassan, W. Welsh, P. Kozlowski, A. Panarin, V. Voronkova, V. Gorbatenko, D. Zatonsky, N. Tereshchenko, T. Shatunova et al. contemplate the territorial development from different perspectives. Postmodernists take the position that the local community loses its independence due to the growing internal differentiation and interdependence in the process of solving of socio-economic problems. They are certain that the importance of belonging to a particular territorial unit loses value for the developed countries. A territorial feature loses its importance when there are some activities within a system (Postol,2010). Communities, according to the postmodernist school, are united primarily by the interest principle (political, cultural, religious, professional, spiritual, etc.) or within the global problems that are much more significant than the units themselves or even the state level. Modern models and methods of organization of human activity, in accordance with the logic of postmodern trends, do not correspond to the current spatial and political-legal boundaries of states. This leads to the expansion of trans-regional, inter-state, and out-territorial forms of generation and structuring of social, political, economic and other processes. A new form of civil society does not have clearly defined spatial boundaries.

The theory of transnationalism is developing along with the postmodern. According to their views (Keohane and Nye, 1997) the interaction between the various elements of the social system is based on cross-border exchanges and is not a subject to the state regulation. Managing subjects of various activities (to the greatest extent, trade, transport and logistics network, tourism) tend to expansion possible only in the framework of relations "beyond the boundaries". Thus, it stipulates an increas in susceptibility to variations and interaction of the systems within which these non-state actors function, to reduce which is possible only by achieving the effect of sharing the benefits (Rudenko-Sudarieva, 2010).

The theory of constructivism (Griffiths, O'callaghan, Roach, 2008) attaches particular importance to the social (or intersubject) issue of regional development. 
Regionalization from the point of the constructivist approach is considered as a form of social reflection, which is dominant at a particular time due to the perceptions of identity of the local community and has the ability to change under the influence of mutual adaptation.

As a reaction to the theory of constructivist approach in Western Europe, the concept of "emerging regionalism" originates and extends in Western Europe. The destruction of the bipolar world model of development caused the emergence of new models of regionalism such as the Pacific economic cooperation (APEC), black sea economic cooperation etc.

Subsequent to the results of the examination of the conceptual approaches regarding the understanding of the process of regionalization from the point of modern trends, it is worth to mention the following. The introduced views, despite having specific and distinctive features, are complementary, rather than opposite, with a focus on achieving a balanced spatial development and a balance of interests of the world community. At the same time, it should be noted that the presented scientific paradigms and conceptual representations do not fully present the content of the concept of regionalization, particularly in the process of building a new structure of world economic relations and building of a new agenda.

Summarizing the characteristics and peculiarities of modern approaches to the regionalization process, it should be considered as a complex process of amplification within a certain area of the whole set of parameters of mutual dependence, defined in political, economic, social and cultural categories. This process may not be deprived of the subjective characteristics. In a sense it can be compared with the historical process of formation, the socalled regionbuilding, which is not expected to have a single center of power at the same time and has the ability to develop in a non-violent way on the basis of consensus of interests.

Thus, due to the influence of processes of internationalization, liberalization, transnationalization and regionalization modern processes of the universe building take place, where separate national economies are transformed into complex global economic systems in which the boundaries of a national economic space become dynamic and no longer coincide with the boundaries of the geographical space of individual countries, which encourages involvement in global processes of world economic relations not only of state agents but also of other actors on the principles of partnership. A new form of regionalisation that is a global partnership as a precondition for achieving sustainable development is developing, which implies a corresponding transformation of the world system, within which there is a gradual integration of countries into a new global reality. As a result, the world is a global unity, the elements of which are interrelated, as a certain unity in the variety of contradictions. This, in its turn, suggests a new reconstruction of the global geostrategic space and a new vector of sustainable development, where a new system of relations and geopolitical spaces is created.

A new paradigm of regional development suggests the need to clarify the conceptual content of the concepts "region", "international region", "cross-border region, a globalized region, transnational region". Foreign and domestic scholars present different approaches to the the category "region". However, the dominant approach, common in the international and Ukrainian practice, is the spatial one. Since the basis for the formation of the region is the territory on which it is located, the geographical location is important. Any region is the territory, however, exclusively the territorial component is not enough to claim the territory to be a region.

Economic and organizational components are essential for the region formation providing there are the following characteristics:

- complexity and balance of social, economic and environmental development;

- features of development of production and social infrastructures, the specificity of the system of settlements; 
- the ability to create conditions for a harmonious life;

- the ability to produce the amount of goods and services to meet not only their own needs but also the needs of other regions.

Besides the reproductive specificity for the formation of the region it is important to provide its positioning, which requires an effective regional management and the practical identity of the community.

Positioning of the region essence must be implemented on the basis of a "territory playback - system relations - governance" principle.

E. Hurrell (1995) gives the following definition of a region: "a region is a natural, organic principle of a territorial organization of social, political, economic and cultural aspects of life of human communities". In this sense, the region is considered in the domestic aspect as a part of a state. In this case, the development of the country is organically connected with the decision of both national and regional socio-economic problems, in particular, with the regulation of the structure of the economy and solution of specific social problems, including geopolitical, natural, economic and national peculiarities of development of individual countries and regions.

From the perspective of the international community, the region definition must take into account the factor of international specialization and a system of internally regional and interregional relationships.

The concept of "region" at the national level corresponds to the concept of "crossborder region" and "international region" at the global level.

An international region is defined by most authors as a qualitatively new type of community, which may simultaneously include a single region at the national level, their associations, and in the whole states, which reflects the heterogeneity of the internal content and structural fullness of the concept. The region emergence may be both "natural" (defined by the geographical parameters) and "artificial" (created as a political object with a certain well-defined objective, in the future, acquiring new lines in development of relationships and implementation of the scenarios elaborated by international societies). The formation of an international region is also possible on the basis of the common problem or an economic interest in one or another sphere of public life, which is the starting point for cooperation and building of a network of relationships. In most cases, the economic interest, which provides for the mutual benefit of the territories belonging to it is the catalyst for the creation of international and regional structures. Phased construction of an international region is based on the emergence of supranational and regional economic and political institutions. Regional international economic institutions are a specific platform for regular meetings and adoption of joint solutions. The level of integration of territories into an international region depends on the availability, the level of development and stability of economic governance institutions.

M. Muntean (2009) distinguishes three groups of factors and, accordingly, three levels of formation and development of international regions. The first group is the factorspreconditions - geographical, socio-psychological, cultural fators, and so forth. The second group of factors is the factors-basis - economic factors. The third group is the factors-add-in with any configuration of the regional structure possess a subjective-strong-willed character, political factors. The absence of the first group of factors significantly weakens the regional order, and the absence of the second or third group results in its destruction.

New regions, appearing as an international integrated formation, can be divided into two large groups. Firstly, they are so-called "homogeneous" regions, subdivided into three subtypes: 
a) natural regions, the boundaries of which are defined by general topographic, climatic and other natural characteristics;

b) regions with a strong sense of shared cultural and historical identity;

c) economically self-sufficient regions with a common type of industrial production.

The second group is the so-called functional regions, parts of which initially are not necessarily similar to each other. The concept of creating functional regions involves internal interaction and integration to achieve mutual complementarity and association of local components.

The above characteristics make it possible to define an international region as a region of the world economy with dynamic and often set territorial boundaries and parameters of economic, social, political and cultural interaction, which integrates (totally or partially) the reproductive processes of several countries, based on the specificity of territorial structure of economy, natural and human resources to jointly address common problems and ensure economic growth and welfare of member countries.

Thus, an international region appears as a certain system of countries, formed in the process of historical development and influences the international community through its economic power, cultural and scientific-technical potential (e.g., the triad USA-EU - Japan); or it can be viewed as a homogeneous group of countries with territorial unity, proximity, levels of economic development, the presence of common problems and tasks, that is, as a regional economic integration group (e.g., European Union).

The establishment of coherent mechanisms and structures of reproduction in the development process gives rise to regions of different levels of complexity, which can be localized on certain parts of the territory, attach to them and to rely on certain complexes of natural resources. The presence of the international region and its boundaries are determined by the nature of the programs of economic cooperation and real economic practice.

Cross-border regions can be named along with international regions in the world economy in the process of regionalization - local groups, regions, individual states with closer ties and specific characteristics in relation to the entire region. As a rule, the dimensions, the extent and nature of identity of the community, prevent it from becoming a self-sufficient structure, so the external connections to it are more significant than internal ones.

In the course of formation of transboundary regions the process of integration with other or the same subjects takes place on a new basis and new non-state actors that is cross border institutions are created, and are defined by the relationships implemented across the border and are of public nature. It can be both the relationships on the basis of intergovernmental agreements, and direct ties that unite groups of people on both sides of the border.

The most important component of the cross-border region is a network of internal channels and connections. The links between similar actors and between actors at different levels are possible. Transnational communication channels and network ties are formed not only between regions but also between individual enterprises, firms, educational institutions, non-governmental organizations, that is, those who fill the cross-border cooperation with concrete content.

It is natural for the region to rely on various competitive advantages. The role of the states in this process is to create conditions that promote these relationships, to empower micro-regions with a greater autonomy in the international sphere.

The mentioned above information determines the cross-border region as a region of the world economy, emerging on the basis of strengthening of mutual foreign economic activity of regions of different countries and their business structures with the purpose of obtaining the 
benefits of international division of labor within the framework of interstate and interregional agreements.

L. Yaremko (2007) introduces the concept of a globalized region, which is defined as "... an economic area, carrying out regular economic relations with foreign countries, which become a significant factor in its socio-economic development. This tpe of region becomes an independent geo-economic entity". In terms of socio-economic and political instability in the world, including in relations between Russia and Ukraine, questions of development of integration processes and transboundary cooperation come to the fore. Under the circumstances, the establishment and development of scientific, business contacts, contacts, "people-to-people", etc will provide not only the revitalization of the peripheral, border areas, maximize their potential, improve living standards and competitiveness of the region as a whole, but also the formation of friendly relations between the nations.

Given the deep-rooted traditions, a long stay as a part of the USSR, the specific relations of Ukraine and Russia, as well as their regions, the automatic transfer of experience of European countries with cross-border cooperation and creation of Euro regions will not provide the expected result. However, considering the practical aspects of cross-border cooperation, we should first turn to the theoretical foundations of the study, in particular, $i$ the notions of cross-border cooperation and its meaning are insufficiently studied.

The problems of border cooperation are of great interest in the scientific community, given the relative "novelty" and a relevant perspective of the issue. Despite a rather short (actually since the late 90-ies of the last century) period of study of cross-border cooperation there is a significant research material, a deep contribution in the formation of which was made by: R. Hertzog, Zh. Mrku, G. Gabbe, L. Abalkin, Yu. Belokin' Yu., A. Gritsai, V. Polterovich, S. Romanov, L. Vardomsky, I. Zverev, ]A. Amosha, P. Belenky, I. Burakovsky, B. Burkinsky, N. Vnukova, S. Hakman, R. Horbluk, B. Danylyshyn, M. Dolishniy, I. Kish, M. Maksimchuk, N. Mikula, S. Pysarenko, S. Studennikov, R. Fedan et al.

However, despite the increased interest and urgency of the problem of cross-border cooperation, most of the issues of theoretical-methodological and a practical nature remain unresolved.

Before presenting author's position, the experience of European countries and presently available definitions should be discussed. To refer to the cooperation between the two countries and on the territories close to the borders, different terms are offered: cross-border cooperation, interregional cooperation, international cooperation, transnational cooperation.

The Madrid Convention (1980) transborder cooperation is defined as "... any joint actions aimed at strengthening and deepening of neighborly relations between territorial communities or authorities under the jurisdiction of two or more contractual parties, as well as the conclusion with this purpose of all necessary agreements or arrangements". The Charter of the Assembly of European regions indicates the term as "interregional cooperation", which refers to any connection established between regions that belong to different countries.

However, it was necessary to improve the categorical apparatus of the concept of an inter-territorial cooperation, which was introduced in Protocol No. 2 of the Framework Convention (1998). This is due to the fact that international relations can join, depending on national legislation, not only the regions of the sub-national level, but also other territorial entities and public authorities and not necessarily the adjacent territory (transborder cooperation).

Regarding to Mikula and Tolkovanov (2011), "international collaboration" means a mutually agreed activity aimed at relations between territorial communities or authorities of two or more contracting parties. Thus, the broadest concept is an interterritorial cooperation, 
which determines the right of any territorial authority to cooperate with any relevant territorial authorities of other states (regions, districts, cities, etc.).

In the framework of European integration processes Ukraine should use terminology that is already widespread in Europe. So, for a long period the term "border cooperation" has been used for a long time in Ukraine, and only in the last 10 years the concept of "crossborder cooperation" has been applied. Therefore, it is advisable to define these terms.

Generalized conceptual-categorical apparatus was introduced by Hans-Martin Tschudi (Switzerland) at the IX meeting of the Congress of local and regional authorities in Europe (Strasbourg, 4-6 June 2002) in the report "Promotion of transboundary cooperation: an important factor of democratic stability in Europe" (Tschudi, 2002). To define all forms of cooperation, taken together, the term "trans-European cooperation" is used.

Differences in concepts can be caused when defining cooperation in the following cases:

- cross-border cooperation - under two-, three - or multilateral cooperation between local and regional authorities (public and private entities can also be included in this context), that is performed in geographically adjacent territories. This also applies to territories separated by the sea;

- international cooperation (inter-territorial cooperation) two, three or multilateral cooperation between local and regional authorities (public and private entities can also be included in this context) that takes place between territories that do not have common borders;

- transnational cooperation - cooperation between national, regional and local authorities programs and projects. This form of cooperation covers large contiguous areas and includes the subjects of at least two member states of the European Union and / or countries that are not members of the European Union" (Tschudi, 2002).

Thus, according to "Practical Guide to Cross-border Cooperation" (2002) in the conventional sense, cross-border cooperation is carried out between adjacent territories. In other words, cross-border cooperation is a specific sphere of foreign economic, political, environmental, cultural, educational and other types of international activities that are undertaken at the regional level and are characterized by the need and possibilities for more active use of the potential of adjacent lands, as well as a number of features, namely the presence of boundaries and the need for its arrangement, the joint use of natural resources and, consequently, the general solution of problems of ecological safety, the wider relationships of the population of neighboring states and the private contacts of people.

According to the current legislation of Ukraine (Law of Ukraine "About the Accession of Russia to the European Convention about the main prinsiples on Transfrontier Cooperation between Territorial Communities or Authorities of 1980" and "About the ratification of the Additional Protocol to the European Outline Convention on Transfrontier Cooperation between Territorial Communities or Authorities № 1879-IV of 24. Jun. 2004About the Changes to the Resolution of the Verkhovna Rada of Ukraine", 2004) the concept of transboundary cooperation is defined as the total actions aimed at the creation and deepeningo f economic, social, technological, environmental, cultural and other relations between territorial communities, their representative bodies, local executive authorities of Ukraine and territorial communities, the relevant authorities of other States within their competence, which is defined by national law (Law of Ukraine "About the cross-border cooperation", № 1861-IV of June 24, 2004, Resolution of the Verkhovna Rada of Ukraine "About Ukraine's Accession to the European Convention on Transfrontier Cooperation between Territorial Communities or Authorities of 1980" No. 3384-XII July 14, 1993). However, this definition does not give a clear understanding on the subjects of cross-border cooperation, focusing on the authorities 
and communities, without considering the business and the population as potential participants. In addition, not formed territorial borders of a cross-border cooperation, this method does not distinguish the concept from inter-ethnic or inter-regional cooperation.

Cross-border cooperation, in accordance with the generally accepted approach (Studennikov, 2000) means the cooperation of adjacent territories of neighbouring states, that is, the determining factor is the boundary between the cooperating territories. In this context, it is possible to use the term "interterritorial cross-border cooperation", when border regions or cities cooperate, but the cross-border cooperation of countries that are not neighbours is impossible.

According to Ukrainian scientists N. Mikula (2004), there are some differences in the interpretation of article 1 of the Additional Protocol to the European outline Convention, when conclusions are made about the unreliability of the availability of the border for crossborder cooperation (Additional Protocol to the European Outline Convention on Transfrontier Cooperation between Territorial Communities or Authorities on November 9, 1995). However, the preamble to Protocol No. 2 to the Convention indicates that cross-border cooperation takes place between authorities of neighbouring territories, and between foreign authorities that are not neighbours that is interterritorial (Protocol No. 2 to the European Outline Convention on Transfrontier Cooperation between Territorial Communities or Authorities, 1998).

There are some differences in the definitions of cross-border cooperation given by the researchers. So, P. Bilenky and N. Mikula (2001) define cross-border cooperation as a specific sphere of implementation of international relations at the regional level, which is characterized by the need and the possibility of their active use, a common border, the need to address the problems of environmental safety, broader general communication of the population of the neighbouring countries and a much greater burden on the social and economic infrastructure.

The cooperation of neighboring territories by its nature is defined as both concepts. The first is more usual for Ukraine, as it was used in conditions when the boundary was sufficiently closed to the public exchange. The establishment of cross-border associations (Euroregions) and implementation of projects to solve common problems of the neighbouring territories neither on the interstate or the interregional level, was not discussed (Mikula, 2003). Border territories of each of the bordering countries, common problems were the objects of the research and were not analyzed.

The concept of "cross-border cooperation" began to be used in the 70-ies of the last century to define the cultural and political relations between neighbouring regions on both sides of the border. Also the term was used to define the border trade which started to developed in 1973-75 on the basis of direct agreements between the regional unions of consumer cooperatives in Ukraine and cooperation organizations of Hungary, Czechoslovakia, Poland and Romania, and since 1980 - and between the organs of government commerce of the border regions of these countries (Kucenko,1998).

However, in the conditions of development of interstate relations, strengthening of integration ties, the term "cross-border cooperation" is now more often used ("trans" in translation means to carry, move, etc.). This category corresponds more to the essence of what is happening in the border areas, but, nevertheless, is not full.

In our view, both notions are confined to the territorial boundaries, a priori narrowing down the content of this multidimensional and comprehensive process. In this regard, without claiming to change the conventional categories, we offer to look at the process of cross-border 
cooperation wider, as if "erasing" the boundaries of borders through the prism of global partnership (Fig. 1.1).

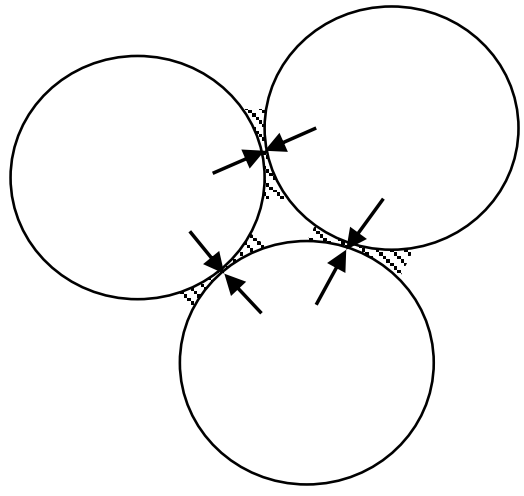

a) near-border cooperation

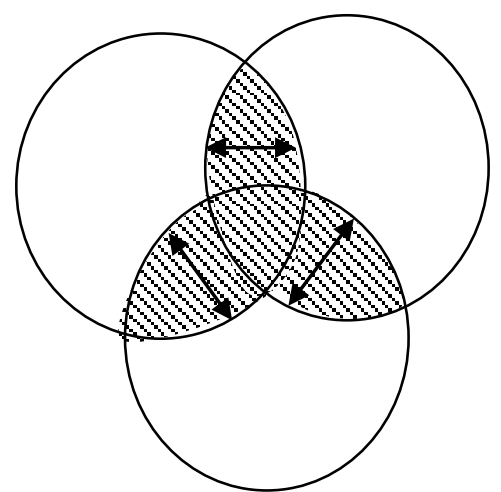

b) cross-border cooperation

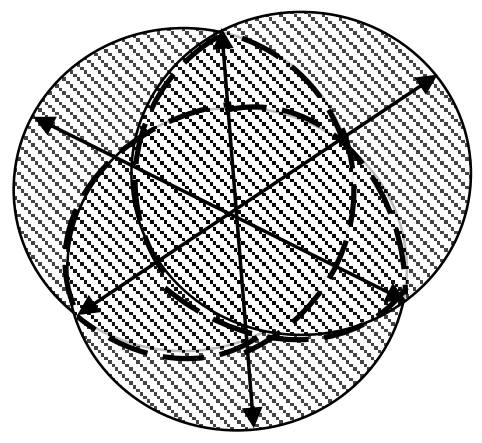

c) global partnership cooperation-without-frontiers

Figure 1.1. The semantic load of the concept of territorial cooperation Sourse: compiled by the author

Not claiming for a change of the standard terminology, we believe that it is necessary to extend the notion of "cross-border cooperation" through the prism of the global partnership that must comply with the pattern) cooperation without frontiers (borders), which provides for mutually agreed shared purposeful activity (authorities, population, business and neighboring countries) to address social, economic, environmental, and other issues of territorial communities in the neighboring countries. With this collaboration the relationship field is broadened to cover not only the surrounding areas but also more remote ones, but which have common problems and joint solutions. The peculiarity of this understanding of cross-border cooperation is the empowerment of problem-solving through mutual assistance of neighbouring countries. The cooperation should cover the greatest possible number of spheres of activity and coordinated actions which will ensure the emergence and strengthening of the synergetic effect of the interaction, which in turn will increase the level of competitiveness of adjacent areas and neighbouring countries in general.

Thus, it is possible to note that transboundary cooperation should be extended to the concept of global partnership "cooperation-without-frontiers" (cooperation without borders). 
In this sense the physical state border between the two countries with the limits of cooperation must not be understood as a barrier, an obstacle, a lack of understanding and unwillingness for joint problem solving.

It is clear that the proposed hierarchy of concepts, like most others in various fields of knowledge, to a certain extent is conditional. However, such an understanding will significantly expand the scope of shared interests and, accordingly, possible solutions to common problems.

In this context under the conditions for the development of a global partnership, we believe that the semantic load of the concept of cross-border cooperation must correspond to the term "cooperation-without-frontiers" (cooperation without borders), which implies a mutually agreed shared purposeful activity (authorities, population, business and neighboring countries) to address the social, economic, environmental and other issues of territorial communities in neighboring countries. With this collaboration the relationship field is broadened to cover not only the surrounding areas but also more remote ones, but which have common problems and joint solutions. The peculiarity of this understanding of cross-border cooperation is the empowerment of problem-solving through mutual assistance of neighbouring countries. The cooperation should cover the greatest possible number of spheres of activity and coordinated actions which will ensure the emergence and strengthening of the synergetic effect of the interaction, which, in turn, will increase the level of competitiveness of adjacent areas and neighbouring countries in general.

In the above context, the level of regionalization in the contemporary world economy can be demonstrated in a diagram (Fig. 1.2).

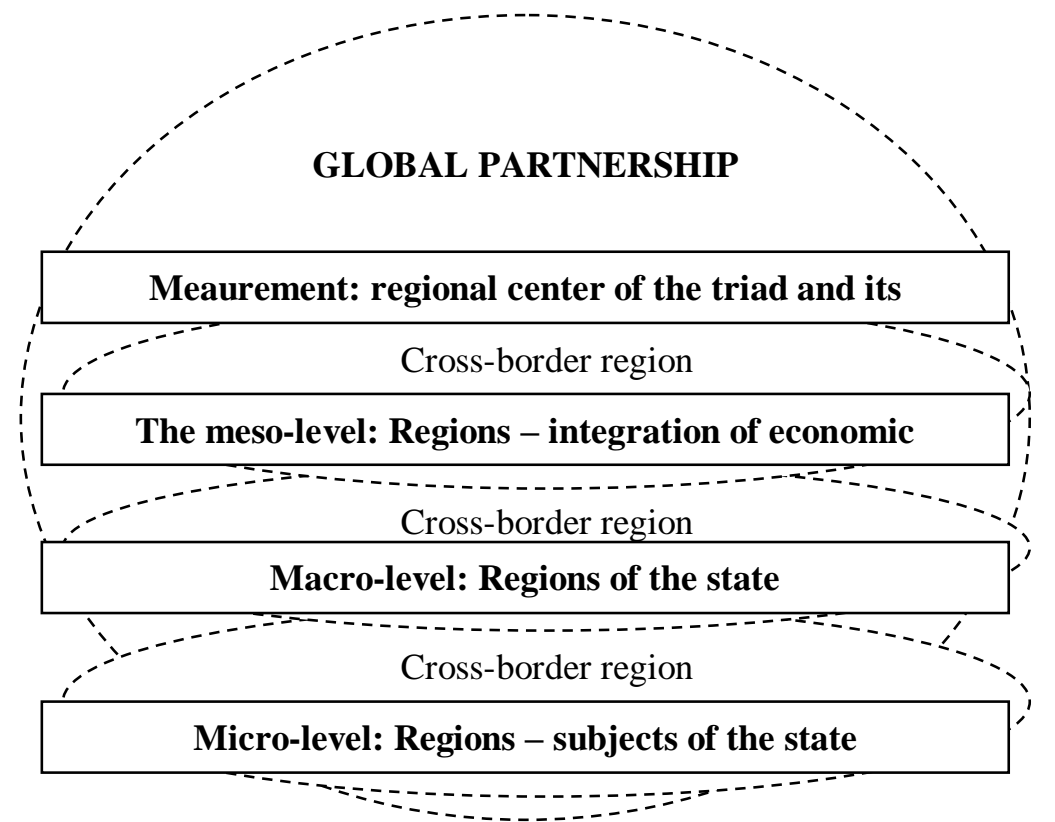

Figure 1.2. Levels of regionalization in the world space

Sourse: compiled by the author

Thus, it can be concluded that the process of regionalization in today's global economy is presented by not only shaped in the process of historical development by region-states and regions of the reinforced effect of the triad, but also purposefully created by the international 
regions (on the basis of cooperation) (based on cross-border cooperation between different countries). As a result, the process of regionalization takes place on four spatial levels: the meta-level of regionalization is determined by the dynamics of the interaction centres of the world economy and their subsystems; the meso level is identified with the process of regional economic integration and operation integration groupings; the macro level covers the area of one country and is associated with the intensification of foreign economic activity of its administrative-territorial units. In the context of global partnerships, cross-border cooperation plays the role of a specific "catalyst" for the creation of regions of higher levels and mediates the relationship between the countries of the world. The global partnership should be seen as a unique complex system of relationships, the inputs of which are different kinds of resources with the emphasis on human resource, the integration serves as a transformative process and regionalization is the result of the system.

The global partnership is a fundamentally new paradigm of building the system of relationship of individual areas, regions, countries and their associations. In accordance with the idea of the study, the global partnership is the highest level of cooperation between different levels of territorial formations on the basis of interregional cooperation, communications and social cross-border cooperation, which is carried out with the aim of achieving the sustainable development goals of the world community. Figure 1.3 shows the author's approach to the transnational relations in the context of this new paradigm.

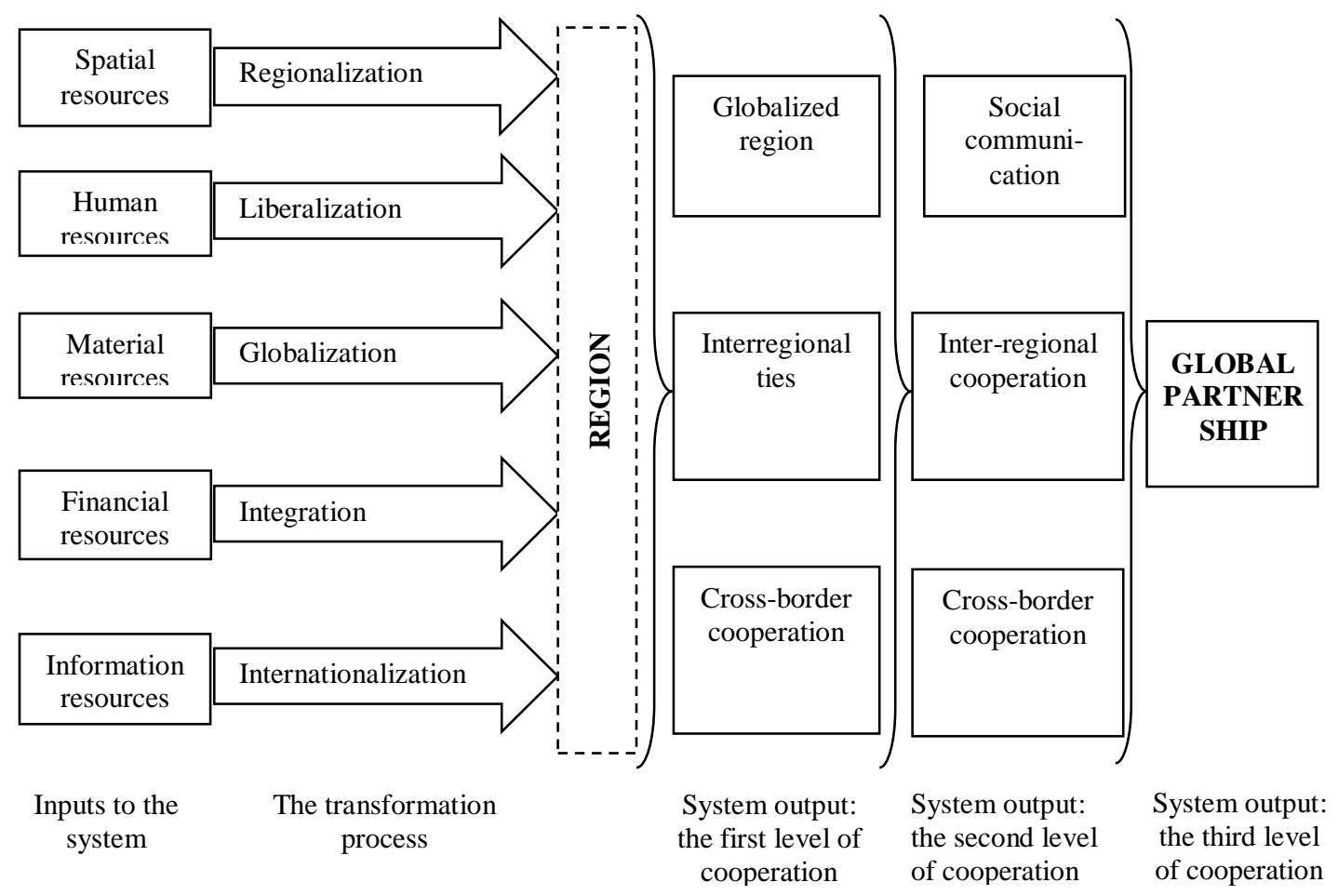

Figure 1.3. The system of transnational relations: a new concept

Sourse: compiled by the author

The global partnership as a new form of social order and a precondition for achieving sustainable development involves the appropriate transformation of the world system, within 
which there is a gradual integration of countries into the a new global reality. As a result, the world is a global unity, the elements of which are interrelated, as a certain unity in the variety of contradictions. This, in its turn, suggests a new reconstruction of the global geostrategic space and a new vector of sustainable development, where a new system of relations and geopolitical spaces is created.

\section{References}

Additional Protocol to the European Outline Convention on Transfrontier Cooperation between Territorial Communities or Authorities on November 9, 1995.

Bielienkyi P. Yu, Mikula, N. (2001). Formation and development of system of interregional and cross-border cooperation in Ukraine.RegionalEconomics. No.3, 61-74.

Charter of the Assembly of European Regions. Available at: http:www.iza.or.

Crawford, G., Ostrom, E. (1995) A Grammar of institutions.American Political Science Review.Vol. 89.No. 3.

European Outline Convention on Transfrontier Cooperation between Territorial Communities or Authorities. May 21, 1980, Madrid: Council of Europe.

Griffiths, M., O'callaghan, T., Roach, S. (2008). Constructivism. International Relations: The Key Concepts (Second Edition). London; New York : Routledge.

Hurrell, A. (1995). Explaining the Resurgence of Regionalism in World Politics.Review of International Studies. Vol. 21, 333.

Keohane, R., Nye, J. (1977). Power and Interdependence: World Politics in Transition. Boston: Little Brown \& Co.

Kryvets, N. V. (25004) The agreement on the dissemination of the Rapallsky Peace Treaty, 1922 between the USSR republics 1922. Encyclopedia of history of Ukraine. Kyiv: Naukova dumka. Vol. 2, 432.

Kucenko, V. (1998). Near-border economic cooperation of foreign countries: the experience for us. Foreign trade. No. 1-3.

Law of Ukraine (2004) About the Changes to the Resolution of the Verkhovna Rada of Ukraine" about the Accession of Ukraine to the European Convention about the main prinsiples on Transfrontier Cooperation between Territorial Communities or Authorities of 1980" and the ratification of the Additional Protocol to the European Outline Convention on Transfrontier Cooperation between Territorial Communities or Authorities. No. 1879-IV of 24. Jun. 2004.

Law of Ukraine (2004) About the cross-border cooperation. No. 1861-IV of June 24, 2004. March, J, G., Olsen, J. P. (1984). The new institutionalism: organization al factors in political life. American Political Science Review.No78 (3), 734-749.

March, J. G., Olsen, J. P. (1996) Institutional Perspectives on Political Institutions. Governance: An International Journal of Policy and Administration. Vol. 9, No. 3, 247-264.

Mikula, N. (2003). The main methodological approaches to the evaluation of European region's activities. Problems of foreign economic relations and attract foreign investments: regional aspect. Collection of Scientific papers. Donec'k: DonDU.

Mikula, N. (2004). Inter-territorial and cross-border cooperation. L'viv: NAN IRD of Ukraine.

Mikula, N. A., Tolkovanov, V. V. (2011). The cross-border cooperation. Kyi'v: Kramar.

Muntean, M. A. (2009). Geopolitics.History and modernity. Moscow: NP "Center of public expertise". 
Mykoliuk, V. A. Conceptual measurement of theory and approaches to the European integration. Ukrainian scientific journal "Education of a region": Access mode: http://socialscience.com.ua/article/82.

North, D. (2005). Understanding the Process of Economic Change. Princeton: Princeton University Press.

Peters, G. (1998) New institutionalism in political science. The New Institutionalism in Political Science. London: Cassell.

Postol, A. A. (2010). Postmodernism as a contemporary socio-political reality.Humanitarian Bulletin of Zaporizhia State Engineering Academy. Vol. 42, 69-79.

Practical Guide to Cross-border Cooperation (2000). Third Edition 2000 Available at: http: www phare/AEBR/EC/216.

Protocol No. 2 to the European Outline Convention on Transfrontier Cooperation between Territorial Communities or Authorities.Strasburg, 1998.

Protocol No.2 to the European Outline Convention on Transfrontier Cooperation between Territorial Communities or Authorities. Strasburg, 1998.

Resolution of the Verkhovna Rada of Ukraine (1993) About Ukraine's Accession to the European Convention on Transfrontier Cooperation between Territorial Communities or Authorities of 1980. No. 3384-XII, July 14, 1993.

Rudenko-Sudarieva, L. (2010). Processes of globalizations and transnationalizations.Journal of Europian Economy. Theoretical and methodological approach to comprehensive evaluation (part 2).: Publication of Ternopil National Economic University. No. 3, 271-296.

Studennikov, I. (2000). Cross-border cooperation and its place in the regional development. Regional policy in Europe: Lessons for Ukraine: ed.by S. Maksymenko. Kyiv: Naukova dumka.

Tschudi, H-M. (2002). Promoting transfrontier cooperation: an important factor of democratic stability in Europe.Strasbourg. 4-6 June 2002.

Wallerstein, I.(2005). Modern World-System in the Longue Duree.Fernand Braudel Center Series.

Yaremko, L. A. (2007). Globalized region and foreign economic security of Ukraine: theoretical and methodological aspect. Lviv : LKA Publishing house.

Yaremko, L. A. (2007). Globalized region.The Economist. No. 5, 54-57.

\title{
1.2. GLOBAL PARTNERSHIP: TRANS-BORDER DIMENSION
}

\author{
YuliiaTkachenko \\ PhD (Economics),Associate Professor \\ Associate Professorof the Finance Department, \\ Cherkasy State Technological University, Cherkasy, Ukraine
}

Successful implementation of the agenda in the field of sustainable development is impossible without establishing of comprehensive partnership on global, regional and local levels between governments, a private sector and a civil society, built on the principles and values, a common vision and common goals aimed at serving the interests of humanity and the planet.

The development of the society and the international community in general in the modern globalised world depends on the achievement of sustainable development, declared in 
the global sustainable development program up to 2030, unanimously adopted on September 25, 2015 by 193 Member States of the United Nations at the Summit on sustainable development in New York City.

New goals of sustainable development (GSD), followed to day by many countries of the world, establish their own development indicators and include 17 goals and 169 specific objectives (Resolution, 2013). The 17th purpose, but not the last one,"Partnership for the purposes of sustainable development" is considered to be one of the most importnat. This objective is based on the idea of unity, cooperation and development of international communications for the purpose of solving global problems of humanity. In our opinion, the specified target is primary towards others, because the global partnership as the philosophy of the world economy relations organization ensures the elimination of inequalities and disparities of areas development and are a prerequisite for solving other vital problems.

The global partnership represents a form of the constructive dialogue between various communities, sometimes in a confrontation. The basis for such a relationship can be a set of factors, which include the difference in the system of religious, political, economic, cultural and even moral values (Wojtowicz, 2015).

According to Report of the high level Group on the agenda development for the period after 2015 "New global partnership: eradication of poverty and transformation of economies through a sustainable development " (2015), the most important transformation is a formation of a new solidarity spirit, cooperation and mutual responsibility - the agenda principles for the period after 2015. A new global partnership should be based on a general understanding of all people's unity and the need for mutual respect and aid. Global partnership should include not only the government activities, but also the participation of all members of the society, international organizations, local governments, business communities, academic institutions, private charities funds, etc. Each priority area of public life must be maintained by a dynamic partner relationship on the basis of new mechanisms and ways of interaction and responsibility of each participant.

Communiqué of the high level Group (March 27, 2013) were mentioned, that the global partnership should be based on the principles of equality, solidarity, respect for the person and general liability.

Mutually beneficial partnerships based on cooperation and the cooperation are necessary for the exchange of innovation, technical skills and resources, to provide support for capacity building at all levels, for mutual support during crises and for the development of transparent world ties.

The partnership between different sectors (e.g., such as health, agriculture, transport, trade, education, defense) is also of great importance for building full-fledged systems, prevention and response, which must resist any threats to public health and, in case of emergencies, to provide the possibility of emergency mobilization of the necessary resources.

Global shift in the legal, institutional, structural, financial, technological, communication conditions in the international division of labour led to the strengthening of the role of local factors in the development of the world community and increased the dynamism of the regionalization process in the world economy. The regionalization by its content and the implications transforms into a new form of "localization" which provides for the involvement of the individual national territories in the globalization process.

The subject of economic regionalization in the modern global economy is not only the countries that are part of various territorial associations and their subsystems, regional economic integration association, national economy but also regions within the country. 
Now the attraction of regions to the integration processes has become an exceptionally important factor stimulating their socio-economic development at the expense of the free movement of goods, services, capital, technology and manpower between internal and external markets. The enhancement of the economic interconnectedness of the country's regions with foreign regions, the development of interregional cooperation due to the need for the development of new, more flexible forms of relationships.

The ratio of globalization and regionalization processes in the world economy is studied ambiguously by various schools which signifies the complexity of understanding of the nature and content of the regionalization process in the world economy.

There are several points of view on the processes of globalization and regionalization. The first one involves their opposition, the second one considers parallelism, however, a modern scientific school implies the understanding of these two processes: globalization and regionalization as two complementary characteristics of a single, comprehensive process of the global partnership in the form of a cross-border cooperation.

In this context under the conditions of the development of a global partnership, we believe that the semantic load of the cross-border cooperation concept must correspond to the term "cooperation-without-frontiers" (cooperation without borders), which implies a mutually agreed shared purposeful activity (authorities, population, business and neighboring countries) to address the social, economic, environmental and other issues of territorial communities in neighboring countries. With this collaboration the relationship field has been broadened to cover not only the surrounding areas but also more distant ones but those that have shared problems and joint solutions. The peculiarity of cross-border cooperation understanding is the empowerment of problem-solving through mutual assistance of neighbouring countries. Cooperation should cover the largest possible number of spheres of activity, coordinated actions which will ensure the emergence and strengthening of the synergetic effect of the interaction which, in turn, will increase the level of competitiveness of adjacent areas and neighbouring countries in general.

Existing disparities between the development regions of the country determine not only changes in their socio-economic characteristics and growth rate but also the development and spread of the cooperation cross-border effect of the border regions. This indicates the influence of cross-border effect not only on the territory of occurrence but its spread to neighboring regions and even geographically distant ones (Levchuk V. Yu., 2015).By extrapolation of the theory of poles growth, François Perroux on the theory of spatial localization of the provision with the benefits in the border areas of N. Mikuly (2004)we support the conclusion that the spatial-analytical coordinates of cross-border cooperation in Ukraine should be formed by the corresponding orientation vector and must cover all regions without exceptions.

Ukraine has a favourable geopolitical location, 19 of 25 are border regions, the external border is the longest in Europe $-1390 \mathrm{~km}$ of the land border with EU countries. At the same time, in our understanding, it is the territories that are not frontiers play a key role in establishing of global mechanisms, because they are "in transit" and unite the East with the West and the South to the North (Fig. 1.4).

Tier 1 covers the cross-border area as well as the territories, grasped by the transboundary effect, tier 2 is formed by a synergetic effect and covers more remote territories under its influence.

In the spatial-analytic coordinate of the cross-border cooperation a localized territory is allocated, covering mainly Cherkasy region and a small area of Kiev, Kirovograd and 
Poltava regions, formed at the intersection of the second tier of the trans-boundary (synergetic) effect and plays the role of a global partnership center.

The global partnership as a new form of social order and a precondition for achieving the sustainable development involves the appropriate transformation of the world system within which a gradual integration of countries into a new global reality occurs. As a result, the world is a global unity the elements of which are interrelated as a certain unity in the variety of contradictions. This, in turn, suggests a new reconstruction of the global geostrategic space and a new vector of the sustainable development with a new system of relations and geopolitical spaces.

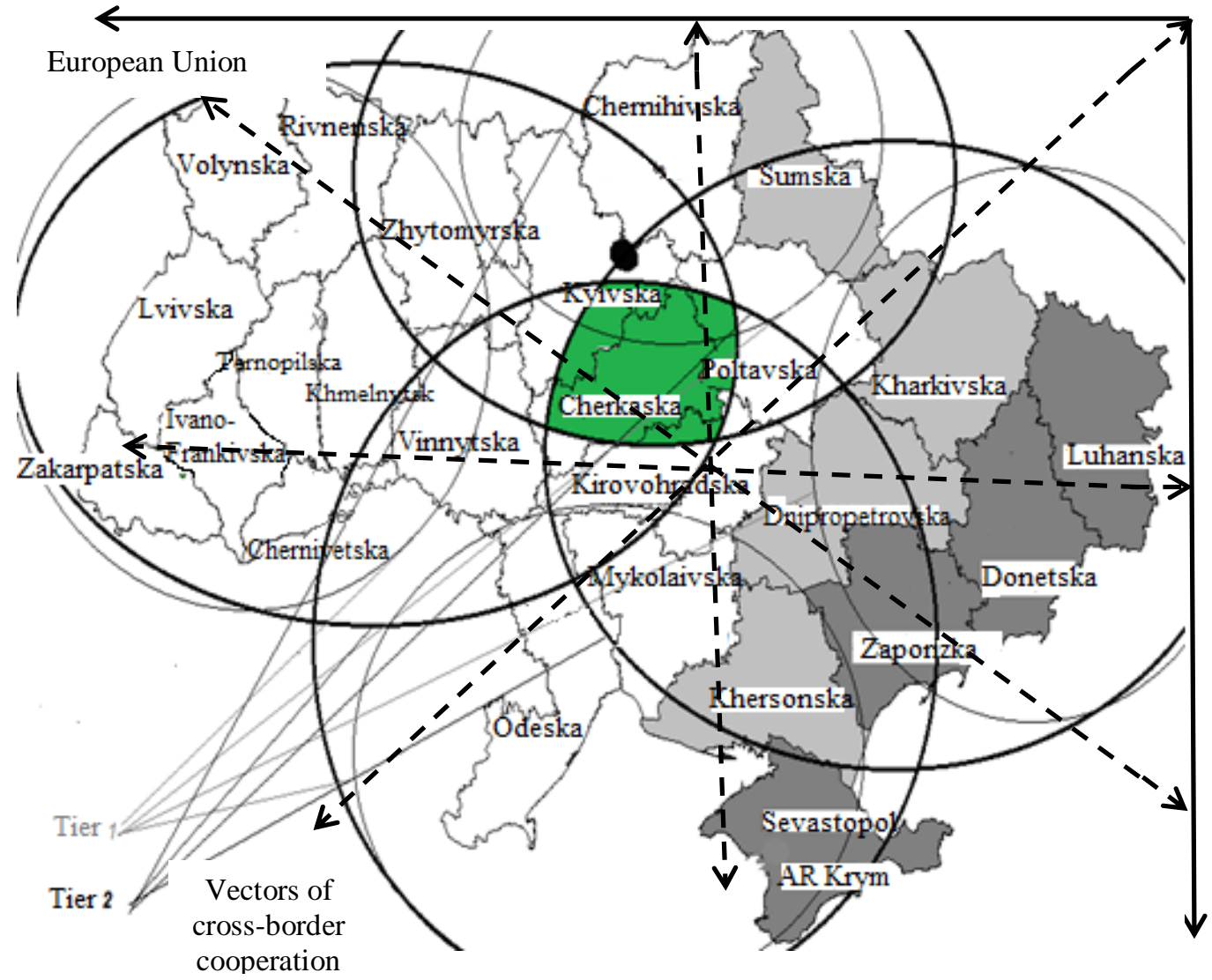

Figure 1.4. Spatially-analytical coordinates of cross-border cooperation in regions of Ukraine

Sourse:compiled by the author

Versatility and absence of the cross-border cooperation concept gives rise to different approaches not only in relation to its definition but also to assess its implementation effectiveness. Despite the unique importance of the issues of the development of the interregional, cross-border and other kinds of cooperation and global partnership the methodological questions are not deeply studied, in particular, there is no single generally accepted methodology for the cooperation effectiveness assessing at any level that narrows the evidence base from the point of view of profitability of participation of regions in this 
kind of partnerships and in terms of the interaction synergetic effect. Scientists made attempts to summarize the methodological approaches to evaluate the effectiveness of cross-border cooperation (Shkola, 2010; Mikula, 2004; Korolchuk, 2008; Tereshchenko, 2006; Shylik, 2007 et al.), most of which are successful, well-developed, fundamental approaches but problematic in the aspect of practical implementation.

Since the cooperation and partnership are complex and multifaceted phenomena of the social development the approaches to their assessment require a systematic and a multi-level structure.

In studies by N. Mikula (2004), the evaluation of cooperation cannot be determined by direct methods. According to her ideas, it is only possible to indirectly estimate the effect of cooperation on the basis of the indirect methods, in particular, using indicators of cross-border trade, mutual foreign trade and investment, amounts of the financial support from international foundations and agencies and public effects of the implementation of measures and cross-border projects etc. In the result the development of cross-border cooperation leads to the improved of the quality of life that is why one more area of indirect assessment includes the quality of life of residents of border areas, as well as the rate of growth in comparison with other regions and the average in the country. efficiency:

Mikula N.A. (2004) offers four directions of assessment of cross-border cooperation

1) the assessment of cross-border trade within the cross-border region;

2) the assessmnet of the development of foreign economic activity development of the border regions participating in cross-border cooperation;

3) the assessmnet of the implementation of joint projects in the border regions, including financial support from the international financial institutions according to the programmes TACIS, PAUCI, from the Carpathian Fund, the DFID (UK);

4) the assessment of communication and border infrastructure in the border regions of neighboring countries.

A different view of the concept of cross-border cooperation results in different approaches to the development of evaluation methods. Accordingly N.A. Mikula (2004) considers only the border area that is the first problem; the second problematic aspect is the lack of baseline data for the analysis (e.g., concerning cross border trade).

Another technique is offered by. T.V. Tereschenko (2006) is based on the multilevel principle and includes an assessment at the micro-, meso- and macro levels. The evaluation of the implementation results of specific projects, programmes, cooperation activities, depending on the scope of activities is assessed on the microlevel. At the meso-level, the collection and unification of the information on the results of the completed projects, the calculation of the indicators, the evaluation of the role of the cross-border cooperation as for the solving of problems of regions, the analysis of the obtained results in dynamics take place. At the macro the cross-border cooperation of border regions as a whole in the state is evaluated in general, determining its place in the solution of regional problems at the national level, the compilation and comparison of the obtained results, decision making support and further development of this cooperation. A set of economic, social, environmental, infrastructural, cultural, educational and other results of border regions is taken as evaluation indicies that show the impact of the projects and programmes implementation in a certain area in a certain period of time. To assess the cooperation it is recommended to determine the parameters in this way: for the absolute ones- as the sum of border administrative-territorial units included in the Euroregion; for the medium parameters - depending on the economic and mathematical content of the indicators. This methodology can conceptual be adapted for the Euro-regional 
cooperation assessment. However, Rogova O.V. (2013) mentioned that the indicators, used within its framework, are quite general and indicate primarily the level of socioeconomic development of border regions, not Euroregional cooperation influence.

Shkola I.M. (2010) proposes to use gradual analysis methods and assessment of the implementation of cross-border cooperation of regions. The first stage involves defining the purpose, object, subject and tasks of the analysis; the second stage is the choice of forms of cross-border cooperation to conduct the study, depending on the development level in the study area. Such forms of cooperation as a basic, institutional, functional and innovative are to be studied. The third stage involves the analysis for each of the investigated cooperation forms on the basis of the appropriate scorecard and information system. At this stage the introduced assessment indicators are classified by groups: general statistics; indicators related to socio-economic and environmental development; - activities (projects) in various areas of cooperation; the border infrastructure. The fourth stage should deal with the study of the direct impact of cross-border cooperation on the socio-economic development of the regions in the selected areas on the interstate, regional, sectoral and social levels. The assessment outcome should determine the the impact to overcome the disparities in the development of border regions (regional aspect), improvement of the public life sectors (sectoral dimension), the provision of priorities of a social nature (social aspect), and the intensification of integration processes between cross-border regions (the integration aspect). The final, fifth stage, on the basis of the identified trends tracks the pinch points of the existing relationships and identifies the areas requiring their activation. The use of the methodology need obtaining and processing of vast data and, as a consequence, the corresponding information support system: information about the regional state administrations, bodies of trans-boundary cooperation management, the main statistical offices in the participating regions, enterprises participating in the cooperation.

All discussed methodical approaches offer a multilevel assessment, which relies on a wide array of information which is difficult to take into account because of the absence of the statistical control and also pays considerable attention to the underlying factors of the regional development, which prevent from distinguishing of their influence on the development of cross-border cooperation (Rogova, 2013).

Global measurement of the closeness of the relationships within the country and abroad, should be determined, in our opinion, on the basis of the correlation analysis for the four indicator groups (Fig. 1.5).To identify objective parameters of involvement of the regions into a single world economic space, given the limitations of statistical data to assess the participation of regions in collaborative projects and initiatives, a rapid method of determining the rate of participation in the global partnership is offered $\left(\boldsymbol{C}_{\boldsymbol{i n}} \boldsymbol{G P}\right)$. On the basis of the available statistical data it is appropriate to determine the proposed ration as the sum of the coefficient of foreign exchange rate of foreign exchange services; the investment exchange coefficient.

$$
C_{i n G P}=C_{G E}+C_{S E}+C_{S E}
$$

where $C_{i n} G P$ - coefficient of participation in the global partnership; $C{ }_{G E}$ - coefficient of the external goods exchange; $C_{S E}$ - coefficient of foreign services exchange; $C_{I E}$ - coefficient of investment exchange.

$$
C_{G E}=\frac{E_{\mathrm{T}}+I_{T}}{G R P}
$$


where $C_{G E}-$ coefficient of the external goods exchange; $E_{T^{-}}$amount of exports, thosand USD USA; $I_{T}-$ amount of imports, thousand USD USA; GRP - gross regional product, thousand USD USA.

$$
C_{S E}=\frac{E_{n}+I_{n}}{G R P}
$$

where $C_{S E}$ - coefficient of foreign services exchange; $E_{S}-$ the amount of exports, thousand USD USA; $I_{S}-$ amount of imports, thousand USD USA; GRP - gross regional product, thousand USD USA

$$
C_{I E}=\frac{D I I_{\text {int heregion }}+D I_{\text {int heregion }}}{G R P}
$$

where $C_{I E}$ - coefficient of investment exchange; $D I I_{\text {in }}$ the region - the amount of foreign direct investment in the region, thousand USD USA; DII in the region - the amount of foreign direct investment from the region, thousand USD USA; GRP gross regional product, thousand USD USA.

According to Report of State Office for Statistics of Ukraine, foreign trade with goods in 2015 Ukraine carried out with the partners from 217 countries around the world. Exported products in 191 countries in the world, imported from 201 countries. The number of enterprises engaged in the foreign trade in exports was 14.7 thousand units, in the import 22.3 thousand units. Exports of goods in 2015 amounted to 38.1 billion. USA and decreased by $29.3 \%$ against the volume of 2014 and $38.8 \%$ against the volume of 2013, the import of goods -37.5 billion USD and decreased by $31.1 \%$ and $50.5 \%$, respectively. The positive balance of foreign trade in goods amounted to 0.6 billion USD (negative in $2013-13.5$ billion USD). The enterprises of Kyiv, Dnipropetrovsk, Donetsk, Kyiv, Zaporizhzhyaand Odessa, Lviv, Kharkiv and Poltava regions were the most active in carrying out import-export operations.

In 2015 foreign trade with goods Ukraine carried out with the partners from 220 countries around the world. Resident enterprises of Ukraine provided services to nonresidents of 214 countries in the world, received from the non-residents of 191 countries. The number of enterprises engaged in the foreign trade in exports was 14.7 thousand units, in the import constituted 22.3 thousand units. Exports of goods in 2015 amounted to 38.1 billion. USA and was reduced by $15.5 \%$ vs the volume of 2014 and $31.6 \%$ vs volume 2013 , imports of services -5.5 billionUSD, and decreased by $13.3 \%$ and $26.6 \%$, respectively. The positive balance of foreign trade in services amounted to 4.2 billionUSD (in 2013. also the positive balance was 6.7 billion USD).

The transactions with the enterprise services in Kyiv, Kiev, Odessa, Dnipropetrovsk, Donetsk, Mykolaiv, Lviv and Kyiv regions were the most active. In 2015 investments were received from 133 countries. EU countries since the beginning of the year made 33154,9 million USD investments (77.4\% of the total share capital), from other countries -9696.4 million USD (22.6\%). Direct investments from Ukraine were carried out in 46 countries, the overwhelming proportion of which was directed to Cyprus (93.0\%). The volume of foreign 
direct investment in Ukraine had significant interregional disparities in 2015, more than 52\% of investments were made in Kyiv The highest income was in Dnipropetrovsk (16.6\%), Donetsk (4.2 \%), Zaporizhzhya (2.1 \%), Ivano-Frankivsk (1.9 \%), Kyiv (3.8 percent), Luhansk (1.3\%), Lviv (2.9 percent), Odessa (3.1 percent), Poltava (2.3\%), Kharkiv (3.6\%) regions. Less than $1 \%$ of the investment was directed in other regions of Ukraine.

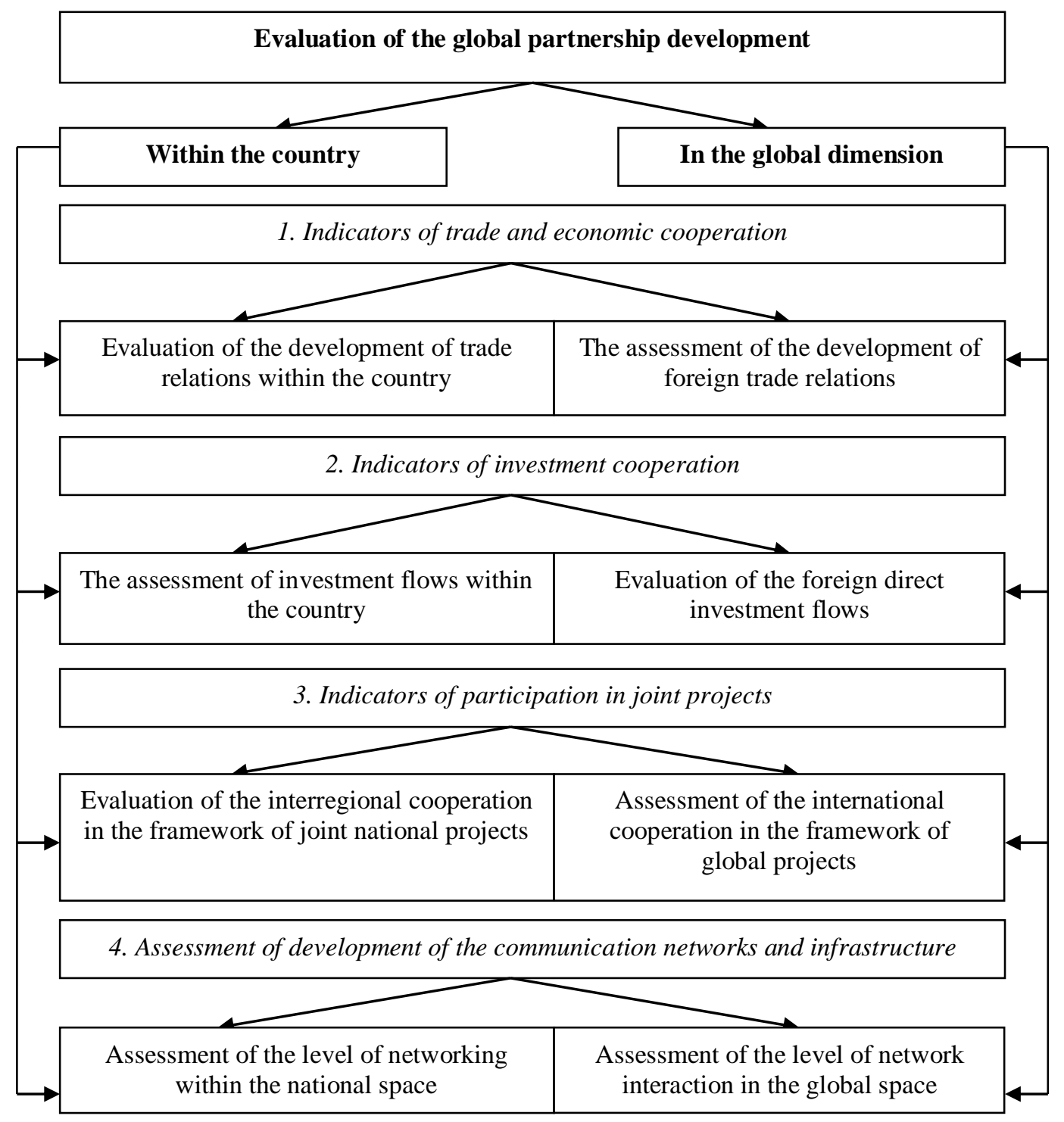

Figure 1.5. Groups of indicators to measure the global partnership development Sourse: compiled by the author

The consideration of international financial assistance is also very important, although in this context mostly the unilateral nature of the cooperation is taken into account and 
therefore it is inappropriate to consider this indicator as a criterion for participation in the global partnership.

The international technical aid, funds aimed at the liquidation of the Chernobyl catastrophe consequences, is unequally distributed on the territory of Ukraine. Significant resources are aimed at improving the institutional capacity of Central bodies of Executive power and are concentrated in Kiev. At the same time, considerable funds are allocated to the Western regions (Lviv, Transcarpathian, Volyn region) and Eastern regions (Dnipropetrovsk, Kharkiv region). The main differences of the projects, implemented in the Western regions, are their lower cost and at the same time a larger number. In particular, in Lviv region there are 54 projects, in the Carpathian there are 46, in Volyn there are 35. This is largely due to the introduction of cross-border cooperation programmes of the European instrument of neighbourhood and partnership (Fig. 1.6).

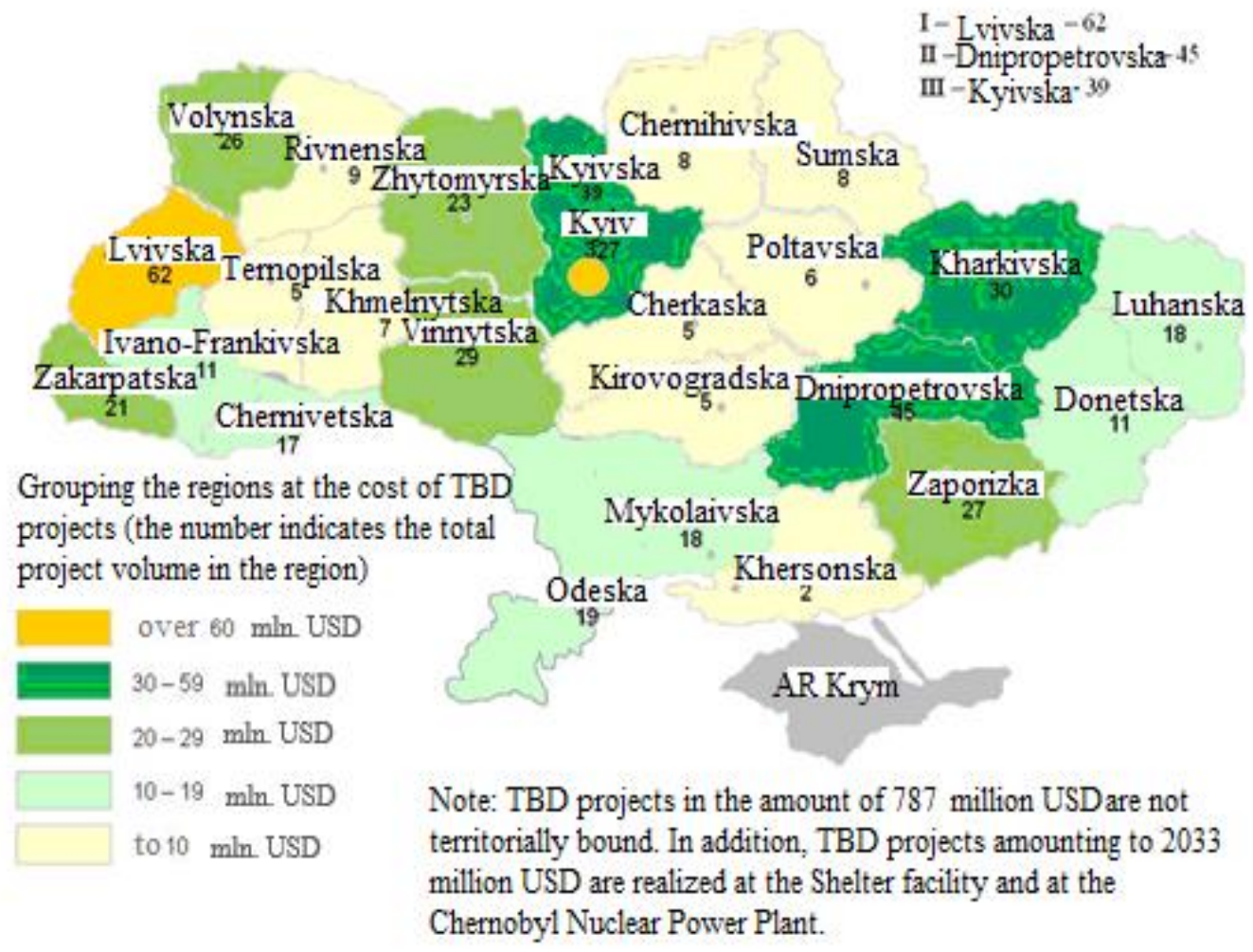

\section{Figure 1.6. Current projects of the international technical assistance during July- December 2014}

Sourse:compiled by the author based on report "Investment of foreign economic activity of Ukraine" by State Office for Statistics of Ukraine

The calculation results of the proposed indicators according to the State statistics service of Ukraine (2015) the coefficient value of participation in the global partnership was defined at the table 1.1 . 
For convenience of calculations it is proposed to use a graphical modeling and represent the level of sectoral participation in the global partnership in a form of a pie chart, the radius of which is equal to the numerical score received. In this case it is possible to determine the coefficient of the region participation in the global partnership according to the formula of the area of the resulting circle:

$$
S=\pi R^{2}
$$

Table 1.1Evaluation of the involvement of regions in the global partnership

\begin{tabular}{|l|c|c|c|c|c|}
\hline Regions Of Ukraine & $\mathrm{C}_{\mathrm{GE}}$ & $\mathrm{C}_{\mathrm{SE}}$ & $\mathrm{C}_{\mathrm{IE}}$ & $\mathrm{C}_{\mathrm{GP}}$ & $\mathrm{S}\left(\mathrm{K}_{\text {in GP }}\right.$ \\
\hline Vinnytsia & 0.528274 & 0.035471 & 0.089238 & 0.652983 & 2.050366 \\
\hline Volyn & 1.081458 & 0.059099 & 0.214 & 1.354557 & 4.25331 \\
\hline Dnipropetrovsk & 1.137723 & 0.082333 & 0.857622 & 2.077678 & 6.523909 \\
\hline Donetsk & 0.851939 & 0.100149 & 1.255639 & 2.207727 & 6.932264 \\
\hline Zhytomyr & 0.481366 & 0.028903 & 0.174502 & 0.684771 & 2.150182 \\
\hline Transcarpathian & 1.822095 & 0.181452 & 0.269522 & 2.273069 & 7.137436 \\
\hline Zaporizhzhya & 1.270649 & 0.066357 & 0.302661 & 1.639667 & 5.148553 \\
\hline Ivano-Frankivsk & 0.370066 & 0.032507 & 0.463817 & 0.86639 & 2.720466 \\
\hline Kiev & 1.122022 & 0.096232 & 0.427039 & 1.645293 & 5.16622 \\
\hline Kirovohrad & 0.371536 & 0.036615 & 0.046735 & 0.454886 & 1.428342 \\
\hline Lugansk & 0.383047 & 0.073709 & 0.393419 & 0.850175 & 2.669551 \\
\hline Lviv & 0.759616 & 0.120166 & 0.367063 & 1.246845 & 3.915092 \\
\hline Mykolaiv & 1.283604 & 0.292949 & 0.125837 & 1.70239 & 5.345504 \\
\hline Odesa & 0.750506 & 0.286684 & 0.377682 & 1.414871 & 4.442696 \\
\hline Poltava & 0.68605 & 0.062477 & 0.299725 & 1.048252 & 3.29151 \\
\hline Rivne & 0.421856 & 0.026875 & 0.159987 & 0.608719 & 1.911377 \\
\hline Sumy & 0.693537 & 0.071582 & 0.139579 & 0.904698 & 2.840752 \\
\hline Ternopil & 0.529938 & 0.051864 & 0.048236 & 0.630038 & 1.97832 \\
\hline Kharkiv & 0.560981 & 0.078937 & 0.341316 & 0.981234 & 3.081075 \\
\hline Kherson & 0.340503 & 0.03082 & 0.189128 & 0.560451 & 1.759815 \\
\hline Khmelnitsky & 0.428845 & 0.021194 & 0.108235 & 0.558273 & 1.752979 \\
\hline Cherkasy & 0.35932 & 0.021023 & 0.191464 & 0.571806 & 1.795472 \\
\hline Chernivtsi & 0.258881 & 0.030896 & 0.082236 & 0.372013 & 1.168121 \\
\hline Chernihiv & 0.690494 & 0.023434 & 0.06834 & 0.782267 & 2.456319 \\
\hline Kyiv & 1.357035 & 0.296433 & 1.356778 & 3.010247 & 9.452174 \\
\hline
\end{tabular}

Source: compiled and calculated by author according to the data of State Statistics Service of Ukraine

The largest area of the sector showing the level of participation of the region in the global partnership, belongs to the city of Kyiv, Dnipropetrovsk, Donetsk, Zakarpattya, Zaporizhzhya, Kyiv and Volyn regions (Fig. 1.7).

The total area of the circle that falls on the border regions is of 86.2 relative units, and 5.2 relative units per transit regions. According to the criterion of regions participation in the global partnership it is necessary to do the following grouping:

Group 1 - the regions poorly engaged in the global partnership (the coefficient of participation in the global partnership in the interval from 0 to 1 , inclusive);

Group 2 - the regions characterized by a medium level of engagement in the global partnership (coefficient value in the range from 1 to 2 , inclusive); 
Group 3 - the tregions characterized by a sufficient level of involvement in the global partnership (coefficient value in the range from 2 to 3 );

Group 4 - the regions characterized by a high level of engagement in the global partnership (coefficient 3 and above).

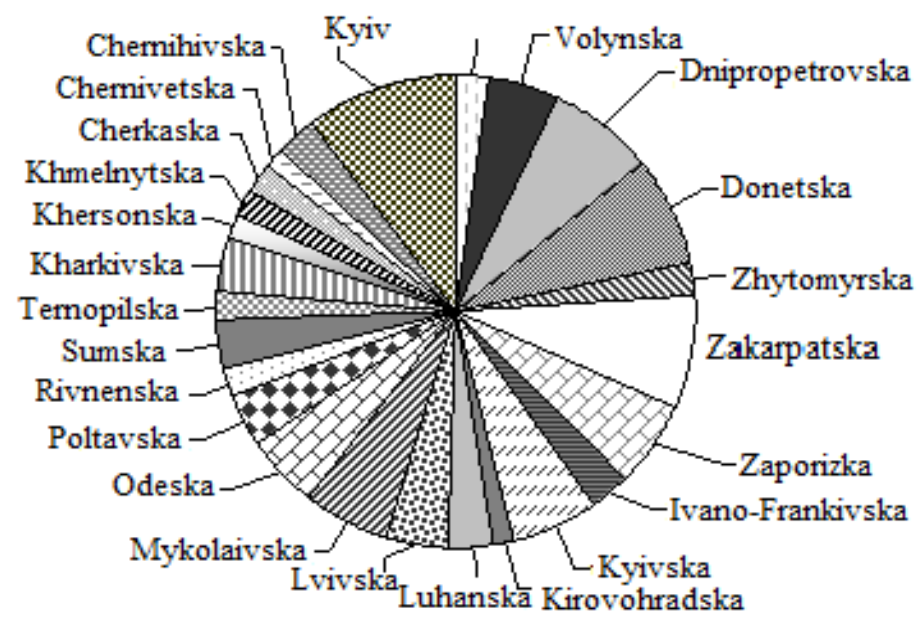

Figure 1.7. The sectoral structure of the regional input into the global partnership Sourse: compiled by the authors

Table 1.2 shows the division into groups. It is to some extent conditional and proportionate in relation to Ukraine, since all regions of the country comparatively to other countries of the world are characterized by a low activity in relation to participation in the system of world economic relations.

Table 1.2. The grouping of regions by the level of participation in the global partnership

\begin{tabular}{|c|c|l|}
\hline Group & Value Of KuGP & \multicolumn{1}{|c|}{ Regions } \\
\hline Group 1 & {$[0 ; 1]$} & $\begin{array}{l}\text { Vinnytsia, Zhytomyr, Ivano-Frankivsk, Kirovohrad, Luhansk, } \\
\text { Rivne, Sumy, Ternopil, Kharkiv, Kherson, Khmelnytsky, } \\
\text { Cherkasy, Chernivtsi }\end{array}$ \\
\hline Group 2 & $(1 ; 2]$ & Volynsky, Zaporozhye, Kyiv, Lviv, Mykolayiv, Odesa, Poltava \\
\hline Group 3 & $(2 ; 3]$ & Dnipropetrovsk, Donetsk, Zakarpatsky \\
\hline Group 4 & $(3$ and more) & Kyiv \\
\hline
\end{tabular}

Source: compiled by the author

In accordance with the proposed approach, based on the available statistical data, it is possible to draw a conclusion about a low level of involvement of most regions of Ukraine, in particular, in cross-border implementation of joint projects and the joint solution of global problems of the mankind.

The suggested express-method is oriented to determine the level of cooperation of the Ukrainian regions with other countries, it can make comparative sectoral analysis in the inner regional context and differentiate regions. In further studies the methodology will be supplemented by the evaluation of the interregional interaction effectiveness.

The problem of cross-border cooperation in the conditions of deepening of integration processes and interregional conflict in Ukraine takes on exceptional significance, the 
successful solution of which depends not only on the level of socio-economic development of the regions, the integrity and unity of the country but also the state of the border territories of other countries Ukraine borders with.

However, in according to the opinion of scientists of the Regional Branch of NISS in Lviv (2015) when there are unconditional benefits of trans-boundary cooperation, the areas involved in it, are exposed to numerous internal and external factors of a subjective and objective nature which have to be thoroughly analyzed from the point of view of possibility to correct the influence of the form and to send it in a positive direction (Fig. 1.8).

A common approach to risk assessment involves the use of two criteria: probability of a risk event occurrence and the scale of the impact factor (Identification of factors and development of cross-border cooperation of border regions of Ukraine on the basis of public opinion research, 2015).

\begin{tabular}{|c|c|c|}
\hline & $\begin{array}{c}\text { The objective } \\
\text { factor }\end{array}$ & $\begin{array}{c}\text { The subjective } \\
\text { factor }\end{array}$ \\
\hline $\begin{array}{l}\text { External } \\
\text { factor }\end{array}$ & $\begin{array}{l}\text { Difficult to } \\
\text { influence }\end{array}$ & $\begin{array}{l}\text { Difficult to } \\
\text { influence }\end{array}$ \\
\hline $\begin{array}{l}\text { External } \\
\text { factor }\end{array}$ & $\begin{array}{l}\text { Difficult to } \\
\text { influence }\end{array}$ & $\begin{array}{c}\text { Can be easily } \\
\text { corrected }\end{array}$ \\
\hline
\end{tabular}

Can be easily corrected

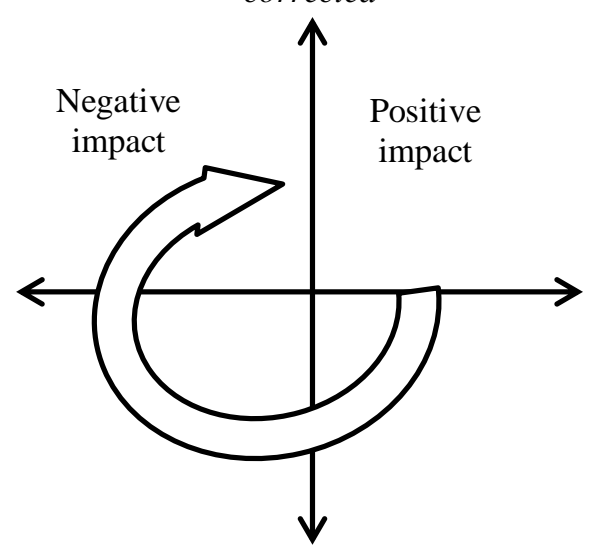

Difficult

to correct

Figure 1.8. Vectors of cross-border cooperation

Sourse:compiled by the author based on report"Identification of factors and development of cross-border cooperation of border regions of Ukraine on the basis of public opinion research", av.at www.niss.lviv.ua/analytics/111.htm)

In our opinion, another factor must be introduced in the three-dimensional risk assessment coordinate system of the cross-border cooperation - the influence of the factor (Fig. 1.9).

Mikula N. A., ZasadkoV. V. (2014) determined the main factors influencing the crossborder cooperation: complex geopolitical situation in the East of the country; the disparity in the development of border territories; the absence of a unified legal framework and mechanisms of cooperation of border territories; the lack of a unified model of cross-border cooperation; the lack of financial resources; the existence of ethnic and cultural barriers; problems of customs and visa character.

Thus, given the complex geopolitical situation in the country, the lack of a unified approach and methodology for the trans-boundary cooperation, its efficiency and development are determined by the influence of the endogenous and exogenous factors, both objective and subjective, which, in our opinion, should be evaluated according to the three- 
dimensional model that can identify the riskiness of the situation, the influence factor and the scale of the of risk occurrence consequences.

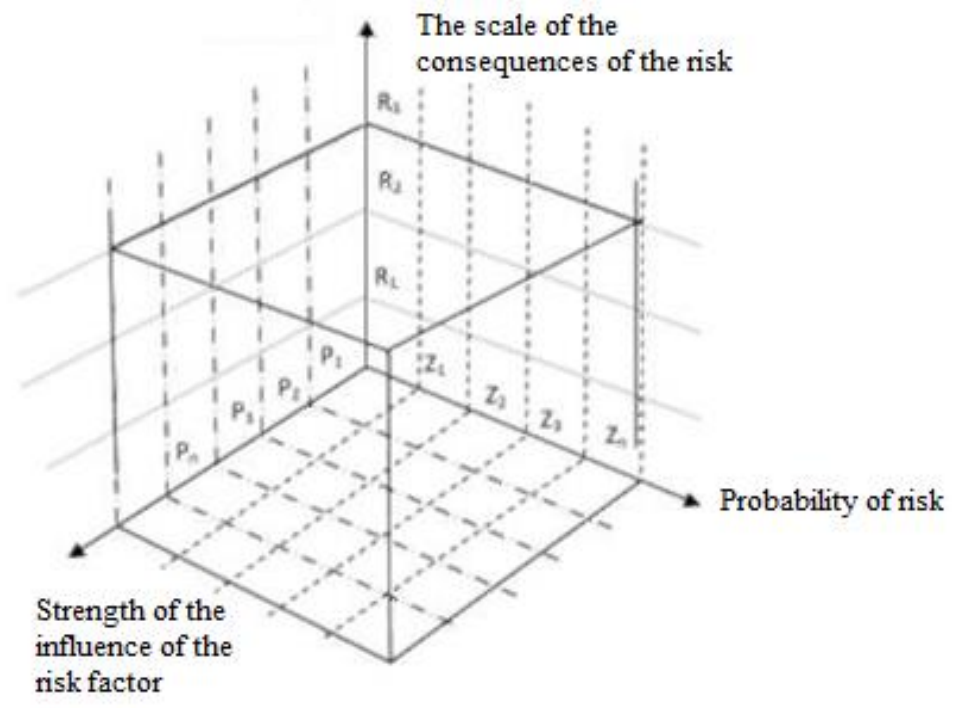

Figure 1.9. A three-dimensional model of the risk factors assessment

Sourse:compiled by the author

Sustainable development in the world, in our deep conviction, is possible only at the expense of the unity of efforts within the country and the principles of trans-boundary cooperation. It should be emphasized that the cross-border cooperation is understood in the context of the global partnership. However, the current situation in the country is an example showing that if to ignore a number of factors and risks, it will result in conflicts, problems of communication and, in general, in disastrous consequences. Therefore, the choice of cooperation mechanisms should be based on the sound risk research methodology with a view to their elimination, mitigation of consequences and in a civilized society, to direct in a positive manner.

Establishing stable friendly partnership relations between neighbours and in the world economy is a key to achieving the goals of sustainable development of the world community and, accordingly, ensuring a high quality of life for present and future generations.

\section{References}

Communiqué of the high level Group, Bali, March 27, 2013 . Available at: http://www.post2015hlp.org/wp-content/uploads/2013/03/FinalCommunique-Bali.pdf

Identification of factors and development of cross-border cooperation of border regions of Ukraine on the basis of public opinion research. Official report of the Regional Branch of NISS in Lviv. Available at: http://www.niss.lviv.ua/analytics/111.htm,

Investment of foreign economic activity of Ukraine (2016) The statistical report. State Office for Statistics of Ukraine. Kyiv: Avrstat. Avable http://www.ukrstat.gov.ua/druk/publicat/kat_u/publ10_u.htm.

Korolchuk, L. V. (2008). Intensification of cross-border cooperation of regions: dissertation for obtain the scientific degree of candidate of economnic sciences, speciality 08.00.08. Lutsk: Les. 
Levchuk, V. Yu. (2015). The cross-border cooperation effect of the border regions. Efficient economy.No. 4. Available at: http: www.economy.nayka.com.ua/?op=1\&z=3991

Mikula, N. (2004). Interterritorial and cross-border cooperation. Lviv: IRR of NAS of Ukraine.

Mikula, N. A., Zasadko, V. V. (2014). Cross-border cooperation of Ukraine in the context of European integration.Kyiv : NISS.

Report of the high level Group on the agenda development for the period after 2015 New global partnership: eradication of poverty and transformation of economies through a sustainable development (2013). Available at:http://www.un.org/ru/sg/management/hlp_report_ru.pdf.

Resolution adopted by the General Assembly on 25 September 2015 / A/RES/70/1 Available at:https://documents-dds-ny.un.org/doc/UNDOC/GEN/N15/291/89/PDF/N1529189.pdf.

Rogova, O.V. (2013). Simulation of Euro-regional effectveness cooperation for adjustment of economic growth rates.Effective economy. No. 3 Available at: http://www.economy.nayka.com.ua/?op $=1 \& z=1897$.

Shkola, I. M. (2010). Methodological approaches to evaluating the effectiveness of cross-border cooperation. Available at: http://www.nbuv.gov.ua/portal/soc_gum/znpen/2010_6/17_MetP.pdf. Shylyk, L. V. (2007). Method of estimation of cross-border cooperation of regions on a local level.Regional policy and cross-border cooperation in the Eurointegrational strategy of Ukraine.Collected papers of the international conference. Uzhgorod, 24-25 May 2007. Educational-scientific Institute of Philosophy and Euro-integration studies edited by: Uzhhorod: Lira.

Tereshchenko, T. V. (2006). Methodical approaches to the evaluation of the results of crossborder cooperation in border regions of Ukraine. Bulletin of Khmelnytsky Institute of Regional Management and Law.No. 6.

Ukraine's foreign trade in goods and services (2015).The statistical report.State Office for Statistics of Kkraine. Ukrstat. Available at: http://www.ukrstat.gov.ua/druk/publicat/kat_u/publ10_u.htm.

Wojtowicz, R. V. (2013). New contexts of global political restructuring of the world: axiological analysis. Scientific notes of the Institute of Political and Ethnic Studies named after I. F. Kuras. Vol. 2, 520-539. Available at: http://nbuv.gov.ua/UJRN/Nzipiend_2013_2_36.

\subsection{FINANCIAL UNITY AS THE FRAMEWORK FOR GLOBAL PARTNERSHIP}

\section{Iryna Goncharenko}

Doctor of Sciences in State Management, Professor,

Head of the Finance Department,

Cherkasy State Technological University, Cherkasy, Ukraine

\section{Olena Berezina}

PhD (Economics), Professor,

Professorof the Finance Department,

Cherkasy State Technological University, Cherkasy, Ukraine

The essential features of the development of modern financial systems of different countries is their tendency to unite in the framework of international financial flows, development of common approaches to the allocation of financial resources, the emergence of supranational forms of financial intermediation etc. All these factors are integral element of 
globalization, which has different manifestations in the economic sphere, and now it is found in the convergence of the economies of many states. Financial globalization is triggered by the growth of financial flows that can have negative consequences, which were manifested in the global financial crises destroying the financial architecture of the world. Thus, it helped it recover in new, more viable forms. The development of globalization processes need further studying of processes of the fiscal unity formation on a global scale, as a phenomenon that can have both positive and negative consequences.

In general, the effects of financial globalization have not been fully defined yet. Virtually there is no formal empirical information confirming the often quoted assertion that the financial globalization was a cause of the financial crises that occurred in the world in the last three decades. However, reliable evidence on the macroeconomic benefits of financial liberalization has not been obtained. Therefore, it is necessary to designate the positive and negative effects of the financial unity and financial globalization, as its manifestation in the global economic system in the form of the important characteristics of the evolution and current state of the global financial architecture.

The issue of globalization, and, in particular, the financial aspect contained in the basis of the fiscal unity of the world, is revealed in the works of many local researchers, such as D. Y. Mamotenko (2009), that explores the globalization of international financial markets, V. V. Kulishov (2013), who specifies the nature and implications of financial globalization, V.S. Lukyanov (2013), that defines the basic imperatives and the crisis management mechanisms of the globalization of national financial systems, N. M. Ukhnal (2015) that studies the specific features of development of international financial centres in conditions of globalization of the financial system, V.V. Zhuravel (2010) that underlines the features of globalization of the world financial system et al. In foreign publications issues of the studied subjects in certain aspects are investigated in sources (Sheffield J., Korotayev A. \& Grinin L., 2013; Schmukler S. L., 2004; Rousseau P. L. \& Sylla R., 2001; Prasad K. R., Shang-Jin W. \& Kose M. A., 2003). Due to the analysis of the mentioned above works including the author's works (Honcharenko I. \&Berezina O., 2016; Berezina O. Y., Tkachenko Y.V., 2017) it is possible to make a conclusion that contemporary manifestations of the world financial unity, such as the emergence of digital currencies, some of which tend to get the status of the future single currency with both advantages and life-threatening impacts on economic security on a global scale are still remain unexplored. Globalization accompanies the development of all spheres of modern life and is traced in the evolution in different directions. The convergence of cultures, political trends and attitudes, completion of construction of a sole information space on the basis of the newest technologies of storage and data access, intensification of educational and scientific exchange, the high mobility of the inhabitants of the planet, and the formation of a single world economic system proves conclusively that the world is transforming into the area, where goods, services, information, capital and other resources are transferred and new ideas circulate freely together with their carriers and proponents, providing the necessary conditions for the development of supranational structures and international institutions, as well as establishing their close collaboration. Globalization involves the formation of a unified international legal, cultural, informational, economic, and hence financial space. Undoubtedly, the process of financial unity will play a vital role in the global economy of our time, providing a sufficiently powerful impetus to the creation of an entirely new system of financial relations. Let us consider the stages according to which the financial unity of the world occurs, table. 1. 3.

The financial unity of the world is manifested in the formation of a single financial system, characterized by common dominant sources of financial resources, high level of interconnection of financial flows, redistribution of funds between states, unions of states, 
regions, industries to provide the necessary financial support and as a consequence, economic development. The principle of unity of the financial system is implemented in the mechanism of integration of financial plans and balance sheets developed at all levels of governance of the global economy.

Table 1.3. The stages of development of the world financial unity

\begin{tabular}{|c|l|}
\hline Stages & \multicolumn{1}{|c|}{ Specific features of the stage } \\
\hline $\begin{array}{c}\text { Stage } \\
1\end{array}$ & $\begin{array}{l}\text { Establishing of currency exchange rates, the formation of currency baskets, making } \\
\text { monetary exchange, the establishment of financial relations between states }\end{array}$ \\
\hline $\begin{array}{c}\text { Stage } \\
2\end{array}$ & $\begin{array}{l}\text { The rate to the convergence of financial markets; the financial institutions from different } \\
\text { countries such product lines, which allowed financial intermediaries of some state series; } \\
\text { penetration of foreign capital in the regional financial markets }\end{array}$ \\
\hline $\begin{array}{c}\text { Stage } \\
3\end{array}$ & $\begin{array}{l}\text { The creation of international financial companies, expanding their branch networks around } \\
\text { the world, creating a system of supranational regulators of the financial relations, the } \\
\text { origins of the global financial market }\end{array}$ \\
\hline $\begin{array}{c}\text { Stage } \\
4\end{array}$ & $\begin{array}{l}\text { Enhancing the authority of international financial organizations, granting them the right to } \\
\text { solve the financial problems of the global scale and influence on the national financial } \\
\text { system }\end{array}$ \\
\hline $\begin{array}{c}\text { Stage } \\
5\end{array}$ & $\begin{array}{l}\text { The development of payments using on the basis of electronic systems, facilitation of the } \\
\text { access to financial products and services, increase in demand through international } \\
\text { programs for improvement of financial literacy of the population }\end{array}$ \\
\hline 6 & $\begin{array}{l}\text { (Current status) the Gradual leveling of the status of national currencies, distinguishing of } \\
\text { several currencies accepted for calculation in most countries and can claim the status of } \\
\text { global currency; the emergence of virtual, digital currency, completion of formation of the } \\
\text { global financial market and building of its architecture }\end{array}$ \\
\hline Stage & $\begin{array}{l}\text { (In the future) the use of a single digital world currency, the same conditions for the } \\
\text { licensing and activities of financial institutions, the same rules and rates for the use of } \\
\text { financial products and services, the ability to use them anywhere in the world in selected } \\
\text { financial companies }\end{array}$ \\
\hline
\end{tabular}

Source: compiled by the authors

Qualitative development of the financial sector has become a prerequisite for the integration of financial systems of individual countries into the global financial space and its status and level of architecture is one of the main factors that determine the magnitude of the financial growth and benefits that are expressed in maintaining stability, which can provide financial globalization. The higher the level of financial sector development of the state, the more benefits the country will receive from the proceeds of capital in the form of financial growth. At the same time, the dependence on foreign financial flows could cost the state its financial stability, make vulnerable to large-scale financial crises.

At the same time, in developing countries without their own high-performance of the financial sector, the sudden change of direction of financial flows can initiate or exacerbate the cycles of financial ups and downs. In addition, the mismatch of the financial policy between the requirements of the time, the low level of financial regulation, excessive liberalization of the domestic financial sector are the main causes of many crises that may be associated with financial integration, but in fact could be offset under the condition of the national financial services markets of a sufficient amount of foreign capital.

Financial world unity is expressed primarily in the formation of a single financial market. In recent decades, the global (international) financial market has been widely developed and is currently playing a leading role in the global economic system. The trends in the development 
of a single financial market are the following: globalization, internationalization, institutionalization, and disintermidation, the increased level of international competition, integration, convergence, informatization, computerization and concentration of world markets.

The globalization of the international financial market is reflected in the increase of its share in the operations of providing active and passive forms of financial services by residents of different countries. The internationalization of the international financial market means that the high level of diversification of activity of economic entities in different regions of the world makes it impossible to determine their nationality. Integration of the international financial market is one of the most notable trends of the global financial system. Integration processes contribute to the increasing mobility of financial capital and reducing transaction costs in the use of financial products and services. Convergence of the international financial market and its individual segments is a process similar in its substantive essence with the integration, which consists in the gradual disappearance of borders between the national sectors of the international financial market. The process of institutionalization of the international financial market is reflected in the strengthening of the role of financial institutions in the global financial architecture.

Disintermediation - "the leaching of mediation" has become another noticeable trend in the development of international financial market and had a significant meaning for the integration processes in the financial sector. It means the elimination of financial intermediaries (brokers, banks) from transactions between borrowers and lenders or buyers and sellers of financial products and services in the market, allowing both sides of a financial transaction to reduce their costs by refusing to pay commissions and other fees.

Increased competition over the last twenty years among global companies and financial institutions has led, on the one hand, to improvement of the functioning of the international financial market, and on the other, to the growth of requirements for financial institutions with respect to their economic efficiency and financial security. Thus, the only financially stable and profitable companies with a wide network of branches and offices that have a recognizable brand, a good reputation and associate consumer financial services with reliability and stability, which provide them with a high level of customer confidence remain on the global financial market. Increased competition had impact on the concentration of international financial market and its participants. Now the concentration occurs through the mechanisms of mergers and acquisitions, and these transactions are of a supranational, global character.

Computerization and informatization are currently the main trends in the international financial market, because its activities at the present stage are done using a computer and information technology. Their proliferation has resulted in increased use of financial products and services; it has enabled financial institutions to serve their clients in a single financial space. The participants in the international financial market make management, investment, and financial solutions based on sophisticated techniques of computer simulation.

The global financial market international financial centers, which were the largest cities on the planet, in countries where the concentration of financial flows was the most obvious coordinate their activities. The emergence of international financial centers is the requirement of time and opportunity for states to integrate into the modern global economic environment.

Finally the financial world unity will not be achieved without the introduction of a single currency for service payments.

In 1988 economists predicted the emergence of a single world currency. Let us quote a fragment of the publication from the "Economist" magazine: "Thirty years from now, Americans, Japanese, Europeans, and people in many other rich countries, and some relatively poor ones will probably be paying for their shopping with the same currency. Prices will be 
quoted not in USD, yen or D-marks but in, let's say, the phoenix. The phoenix will be favoured by companies and shoppers because it will be more convenient than today's national currencies, which by then will seem a quaint cause of much disruption to economic life in the last twentieth century". Given that the prophecy was made in 1988 for the thirty-year perspective, it should be realized in 2018, what makes this study even more relevant.

At this point USD can be called world currency with some conventions. Although, it isn't used in a number of countries. The international financial relations are based on the American dollar. This situation does not suit the government of a significant number of countries that understand that we should not allow one state to be emission center of the whole world. The desire to introduce a single world currency is quite understandable. The supporters of the innovations propose to create a new instead of using of an existing one at the moment. However, in any case, the country that will receive emission right will be in a better position than other participants in the global financial system. Therefore, it is advisable to assume that a new stage of fiscal centralization and globalization will be a single world of digital origin. It can be assumed that it will be similar to the bit coin Block chain, which for many has become a factor of reliability of crypto currencies, proved to be beneficial for market regulators and authorities.

Opponents of crypto currencies claim that their significant drawback is the possibility to use outside the official financial accounts, i.e. for the needs of the shadow economy. However, if the authorities need to track transactions using bit coin, due to the development of modern technologies and information systems, they will be able to do it, no matter how good the attackers will try to hide their actions. The prospect of anonymity while using cryptanalytic has not been completely proven. Thus, there is every reason to believe that central banks and international financial conglomerates will actively use bit coin as a world currency. It will probably appear to be the mythical currency "Phoenix", which was foreseen in 1988.

An incredible amount of capital invested by large financiers in the block chain, support from central banks is a signal that the technology of the block chain will form the basis for the currency system of a "new world order" and accelerate the onset of the financial unity of the world in its perfect form.

What will the introduction of the single global currency on the globalization scale help achieve? Its use will allow avoiding sharp rate fluctuations of national currencies. And will contribute, therefore, to an active development of international economic relations (i.e. economic globalization). This study determines the advantages and threats from the financial unity of the world and financial globalization (see table 1.4), the occurrence of which, however, is inevitable, given the active development of globalization processes in the world.

In spite of the suggestions regarding the possible negative effects of the financial unity of the world, accelerating its onset in a final, perfect form would provide significant benefits for the global economic development.

A study of trends and characteristics of the financial unity of the world as an integral component of globalization has led to the following conclusions.

The world financial unity has been proven to be an integral part of globalization. The convergence of various political, cultural, economic trends, the formation of unions of states, common information space, supranational markets of goods and services necessitated the exchange of financial flows, unification of models of financial intermediation, build the international financial architecture, the emergence of universal means of payment of digital currency. Financial globalization has expanded the boundaries of the capital markets, has ensured their smooth movement to meet the financial requirements and implementation of financial interests both at the macro- and micro-level. Further economic development on a 
global scale would be impossible without the introduction of unified norms and rules of functioning of the financial system.

Table 1.4. Positive and negative effects from the onset of the world financial unity and financial globalization

\begin{tabular}{|c|c|}
\hline Positive consequences & Negative effects \\
\hline $\begin{array}{l}\text { Free exchange of financial assets, financial } \\
\text { products and services in any country of the } \\
\text { world }\end{array}$ & $\begin{array}{l}\text { The possibility to rise prices for financial products } \\
\text { and services by means of the financial oligopoly of } \\
\text { international companies }\end{array}$ \\
\hline $\begin{array}{l}\text { Cost reduction and financial services due to } \\
\text { the tax-free currency exchange }\end{array}$ & $\begin{array}{l}\text { Leaving the financial market for small business } \\
\text { financial forms }\end{array}$ \\
\hline $\begin{array}{c}\text { The increase in the rate of financial services } \\
\text { through the use of single settlement and } \\
\text { payment systems }\end{array}$ & $\begin{array}{c}\text { Total control of international financial } \\
\text { organizations of the functioning of national } \\
\text { financial systems }\end{array}$ \\
\hline $\begin{array}{l}\text { Leveling of the cost of issuing paper money, } \\
\text { provided the use of a single digital currency } \\
\text { (cryptanalytic) }\end{array}$ & $\begin{array}{l}\text { The use of crypto currencies with criminal intent } \\
\text { through the use of information and computer } \\
\text { technology }\end{array}$ \\
\hline $\begin{array}{l}\text { The introduction of the unified rules of } \\
\text { conducting the financial business, single } \\
\text { standards and requirements for the quality } \\
\text { of financial products and services }\end{array}$ & $\begin{array}{l}\text { The increasing number of financial frauds and } \\
\text { economic crimes with the use of computer } \\
\text { technology }\end{array}$ \\
\hline $\begin{array}{l}\text { The ability to control all cash flows to } \\
\text { minimize the shadow economy, funding of } \\
\text { terrorism and money laundering }\end{array}$ & $\begin{array}{c}\text { The possibility of destruction of the entire global } \\
\text { financial system and its architecture by large-scale } \\
\text { hacker attack }\end{array}$ \\
\hline $\begin{array}{l}\text { Improving financial literacy of the world's } \\
\text { population }\end{array}$ & $\begin{array}{l}\text { The destruction of the national financial diversity } \\
\text { of banknotes, coins and other means of calculation }\end{array}$ \\
\hline $\begin{array}{l}\text { The increase in demand for financial } \\
\text { products and services, the ability to use } \\
\text { them to increase the level of welfare of the } \\
\text { population of the world }\end{array}$ & $\begin{array}{l}\text { The redistribution of financial resources in favor of } \\
\text { international financial centers, favoritism in the } \\
\text { allocation of investment capital }\end{array}$ \\
\hline $\begin{array}{l}\text { Facilitating the access to investment } \\
\text { resources on the capital market }\end{array}$ & $\begin{array}{l}\text { The inability to withstand the global financial } \\
\text { crises by the means of national financial systems }\end{array}$ \\
\hline
\end{tabular}

Source: compiled by the authors

Financial unity of the world in its modern form took place in several stages. The establishment of foreign currency exchange rates took place on the first one; the course towards financial markets started on the second one; the third included the creation of international financial companies, the noticeable increase in the authority of international financial organizations happened in the fourth stage; the growth of cashless payments took place on the fifth stage; the present time gradual leveling of the status of the national currency, the completion of the formation of the global financial market and building its architecture was on the sixth stage; the last, seventh stage is expected to implement and use a single digital world currency.Financial globalization can have both positive and negative effects onf the global economic order. However, the onset of the financial unity of the world is inevitable because this phenomenon is an integral consequence of the quality of the upcoming transformation of the world economic plane. Therefore, the level of international financial institutions should develop a list of strategic directives and imperatives to avoid and minimize the threats that may result in further process of unification of the financial system to ensure a high level of global financial and economic security in the future. 


\title{
References:
}

Berezina, O. Y. \& Tkachenko, Yu.V. (2017). Global partnership in the sustainable development paradigm: education, technology, innovation : monograph. Cherkasy: Chabanenko Yu.A.

Get Ready for the Phoenix Source. (1988). Economist. Vol.9, 306, 9-10.

Honcharenko,I. \& Berezina,O. (2016). Cooperation of the bank and insurance business as an effective model: history and present day. Organizational and economic mechanisms of development of the financial system: collective monograph / edited by M. Bezpartochnyi. Riga : Landmark SIA, pp. 83-92.

Kulishov, V.V. (2013). Financial globalization: the essence and consequences. Business Inform, Vol. 3, 303-307.

Lukyanov, V.S. (2013). Globalization of National Financial Systems: Basic Imperatives and Anti-crisis Mechanisms. Finance of Ukraine. Vol. 9, 60-67.

Mamotenko, D.Yu. (2009). Globalization of International Financial Markets. Humanitarian Bulletin of Zaporizhzhya State Engineering Academy, Vol. 39, 229-237.

Prasad K. R., Shang-Jin W. \& Kose M. A. (2003). Effects of Financial Globalization on

Developing Countries: Some Empirical Evidence. Available at:: https://www.imf.org/external/np/apd/seminars/2003/newdelhi/prasad.pdf.

Rousseau P. L. \& Sylla R. (2001) Financial Systems, Economic Growth, and Globalization.Globalization in Historical Perspective.- University of Chicago Press.

Schmukler S. L. (2004) Benefits and Risks of Financial Globalization: Challenges for Developing Countries. Available at: http://siteresources.worldbank.org/DEC/Resources/BenefitsandRisksofFinancialGlobalizationS chmukler.pdf.

Sheffield J., Korotayev A. \& Grinin L. (2013). Globalization: Yesterday, Today, and Tomorrow. USA.

Ukhnal, N.M. (2015). Features of the Development of International Financial Centers in the Conditions of the Globalization of the Financial System.Scientific Papers NDFI. Vol. 2, 17-32.

Zhuravel, V.V. (2010). Features of Globalization of the World Financial System. Bulletin of Kharkiv National University named after V. N. Karazin. Series: Economical. Vol. 911, 133-137.

\subsection{EUROPEAN EXPERIENCE OF INTERREGIONAL COOPERATION AND CROSS-BORDER PARTNERSHIP}

\author{
Yuliia Tkachenko \\ PhD (Economics), Associate Professor, \\ Associate Professorof the Finance Department, \\ Cherkasy State Technological University, Cherkasy, Ukraine \\ Yuliia Makarenko \\ PhD (Philology), Associate Professor, \\ Associate Professor of the Applied Linguistic Department, \\ Cherkasy State Technological University, Cherkasy, Ukraine
}

The questions of development of integration processes and transboundary cooperation in terms of social and economic and political instability in Ukraine move to the forefront. Due to the concentration of population forces, institutions and organizations, enterprises, 
authorities and management on the development of transboundary territories the most complete use of the potential of the territory is provided and the systemic social effect, which is to establish friendly, good-neighborly relations between the inhabitants of the surrounding areas is achieved. The issues of development of integration and transboundary cooperation are actively explored by the world of science.

Since 1990, the European Union provides financial support to transboundary cooperation through the use of a number of initiatives, programs and projects, namely: INTERREG, PHARE CBC, TACIS CBC, PHARE CREDO, MEDA, CARDS, LACE. INTERREG is leading software shell of most projects of the spatial development in different European territories and public (local) initiatives (Community Initiative) of EU according support of the development of the border regions of member countries of the EU and some coastal areas (Bila, 2013).

The works of Ukrainian and foreign scientists (Bila, 2013; Chubaj-Fedorenko, 2012; Dubovik, 2011; Mikula, 2004; Studennikov,2006; at al.), regulatory and legal acts of Ukraine, international agreements, law and regulative acts on regional policy, documents of European Commission and Council of Europe, the General concept of development of border regions of Ukraine and countries of Central Europe, as well as materials published in monographic literature and periodicals, information from the Internet, were used as the information base of research.

Chubaj-Fedorenko G. (2012) mentioned that the development of regionalism in Ukraine occurs under specific conditions and is of a different nature than in Europe. European regionalism is traditionally defined as follows: "... an organized Europe is a regional form of the inevitable process of globalization, the mechanism that provides economic relations, which is a guarantee of peaceful relations". European regionalism is an objective process of implementation of the state, administrative and international potential of subjects of different European countries, the formation and development of a variety of external relations and contacts between them within the framework and within the legal authority. These powers are set by central authorities or with their participation under the existing constitutional acts, as well as taking into account the international obligations of the state as a subject of international law. There is also a point of view, which assumes that the formation of Euroregions and regionalization in general is a way to overcome the negative consequences of globalization. A considerable amount of time and resources that must be mobilized to neighboring countries and regions in order to cope adequately with the consequences of globalization necessitates the existence of free transboundary mechanisms for dialogue between governments and their cooperation. An important area of international integration is transboundary cooperation, which has been successfully developing in the world for a long time.

Analysis of international experience in the development of transboundary cooperation (Cross-border cooperation. Strategy paper, 2007-2013) has shown that the most effective organizational form of transboundary cooperation is the creation of Euroregions. Under this concept we need to understand the area of transboundary cooperation and in its framework the specific transboundary projects are implemented, problems of employment, development of infrastructure, environment, etc. are solved by the way of economic, social, cultural and humanitarian cooperation.

Euroregions are considered to be one of the organizational forms of transboundary relations, which is within their competence and with the consent of the Central government on the basis of a special extended powers with respect to the international cooperation of local 
authorities in border areas have the opportunity to develop a special integrated program of cooperation and to implement specific transboundary economic projects.

The idea of transboundary cooperation in Europe appeared in the 50-ies. Then for the first time after the war a slogan on the approximation instead of separating people boundaries became popular. The main aim of such cooperation is the achievement of mutual social and economic growth, establishment and development of relations between the economic, scientific, cultural and municipal institutions of the regions. In Europe much attention is paid to the importance of transboundary cooperation in the framework of Euroregions, which is seen as a stabilizing factor in the relations between the two countries.

In the area of Gronau on the German-Dutch border in 1958 the first Euroregion was created. Currently, the Euroregion Gronau includes 106 communes and districts of the Netherlands and Germany with a total population of 2 million people and a total area of 8 $351,2 \mathrm{sq} \mathrm{km}$. There are five such Euroregions that cover virtually all the entire border area on the German-Dutch border. The experience of the first Euroregion has received international recognition.

Integration processes in the Euroregions are characterized by some features (Dubovik, 2011), namely:

- participants are not only administrative bodies, but also trade unions, chamber of commerce, which often play a key role in the development of economic cooperation within the region;

- the basis for the cooperation is the specific projects funded from several sources. For example, in the region EMS-Dollard (EDR) (one of the German-Dutch integration associations) there is the following scheme: $50 \%$ of the expenditure is paid by the EU, $15 \%$ is spent from the budget of the Netherlands and Germany, and the remaining $20 \%$ is paid directly by the project participants;

- much attention is paid to social and cultural programs: strengthening contacts in education, health, culture, science, religion, and social informal movements. Special importance is given to personal contacts and the formation of well-developed social infrastructure.

The precondition of emergence of the Euroregions and the result of formation of this trend, as regionalism, was the development of transboundary cooperation. In the EU countries transboundary cooperation is aimed at solving the problems of economic development through the coordinated development of the economy of the neighbouring regions, and especially infrastructure. An important place in this cooperation take also issues of culture and education, social sphere and environment. The focus of cooperation in these areas is caused by the high level of integration of the EU countries.

In relations between the EU countries the border barriers to movement of goods, capital and labor are eliminated, the legal framework of economic activity is unified, there are no significant inter-state differences in the level of wholesale and retail prices for industrial and consumer goods in investment conditions, as well as income and level of living of the population. In the conditions of formation of the single market of the EU countries the external borders serve as the barrier function. Internal borders between the countriesparticipants lost these functions, but geo-economic results and consequences of their long action left in the past.

Euroregion, on the one hand, can be defined as a geographically limited part of the border area, which is formed from the territorial-administrative units on both sides of the border, which are united by common interests in economic development, nature conservation, preservation and development of culture and the intensification of scientific exchanges. On 
the other hand, the Euroregion is a kind of umbrella project under which the bilateral and multilateral sector-specific projects are implemented.

The most common form of organization of transboundary cooperation to ensure sustainable development of territories is the practice of creating "regions", which is widespread throughout Europe. At the present time, the practice of Euroregions is necessary to distinguish between policy intentions and practice of action, the actual experience of cooperation. The objective value of Euroregions for Ukraine is most likely to stimulate dialogue and institutional innovations and to a lesser extent in achieving a new quality of regional development and new economic characteristics of the territory. The formation of Euroregions is caused by concluding cooperation agreements between local authorities in border areas. As a result, there appears the formation of associations of administrativeterritorial units of the municipal and regional (provincial) level which are interested in joint implementation of various projects. The institutional framework of Euro regions are interregional council of deputies of local authorities and regional business associations. The necessary funds for the implementation of projects of Euroregions are searched in the local budgets, the budget of the country, and finances of EU programs are also used.

The concept of Euroregion is the idea of establishing priority "strategic alliances" with one or two or three adjacent territories, and as a result the small square regions are formed; the level of their interdependence and economic integration sometimes exceeds the appropriate level of interconnection with the regions of their countries. In the framework of such small transboundary regions the integration covers firms and companies and educational institutions, the transport infrastructure is well developed, and even transnational bodies of coordination and managementare created.

One of the key objectives of the concept of development of Euroregions is the provision of transparency of internal borders in the EU due to the joint decision of the border regions to solve common or related problems of local and regional character (transport, roads and railway lines, frontier agriculture, environmental protection, the consequences of natural disasters and other). The starting point for the development of such cooperation is often the forming of private initiatives on small projects, which subsequently received the support of the local authorities, and they took upon themselves their further promotion and implementation. Gradually transboundary cooperation has gained a clearer structure, and the general authorities were formed.

The concept of development of Euroregions is designed to solve problems of economic, social, cultural and environmental development in border areas. In addition, it certainly promotes active participation in the processes of European integration of the new countries and their territories on provincial and municipal level. Due to the current geopolitical changes in the early 90 -ies the idea of creation of Euroregions was extended to the countries of Central and Eastern Europe.

A special role in the development of transboundary relations belongs to the largest in Europe transboundary merger of the interregional Association "Carpathian Euroregion" (created on February 14, 1993, with the participation of border regions of Ukraine, Poland, Slovakia, Hungary and Romania), because its activities are fully consistent with the principles of the European framework Convention for transboundary cooperation between the administrative territorial units and local authorities. According to the Charter of the Carpathian Euroregion, the Supreme body of the Association is the Council of the Euroregion. It consists of three representatives from each member of the Association. The main person who is responsible for the functioning of the structures of the Euroregion is the Executive Director. He is elected by the Council from among the candidates on a competitive 
basis and manages the Association's activities through the Secretariat and national representatives. At this stage there are 4 working committees. According to Ukrainian experts, the activities of the interregional Association "Carpathian Euroregion" confirms the appropriateness of its existence, and shows the important role in the establishment of good neighborly relations, the development of economic relations between the border regions. However, there are constraints. Problems of this Euroregion are rather traditional for transboundary cooperation: insufficient activity of local public authorities; the lack of centralized funding from the state; lack of own resources of the regions; differences in customs and tax legislation of the participating countries.

However, the "Carpathian Euroregion" shows another possible disadvantage of European regions - large size. The "Carpathian Euroregion" covers territory, which is equal to a number of small West European States with a population of 15 million people. From the Ukrainian side the Euroregion includes four areas, and that creates serious management problems (Fig. 1.10).

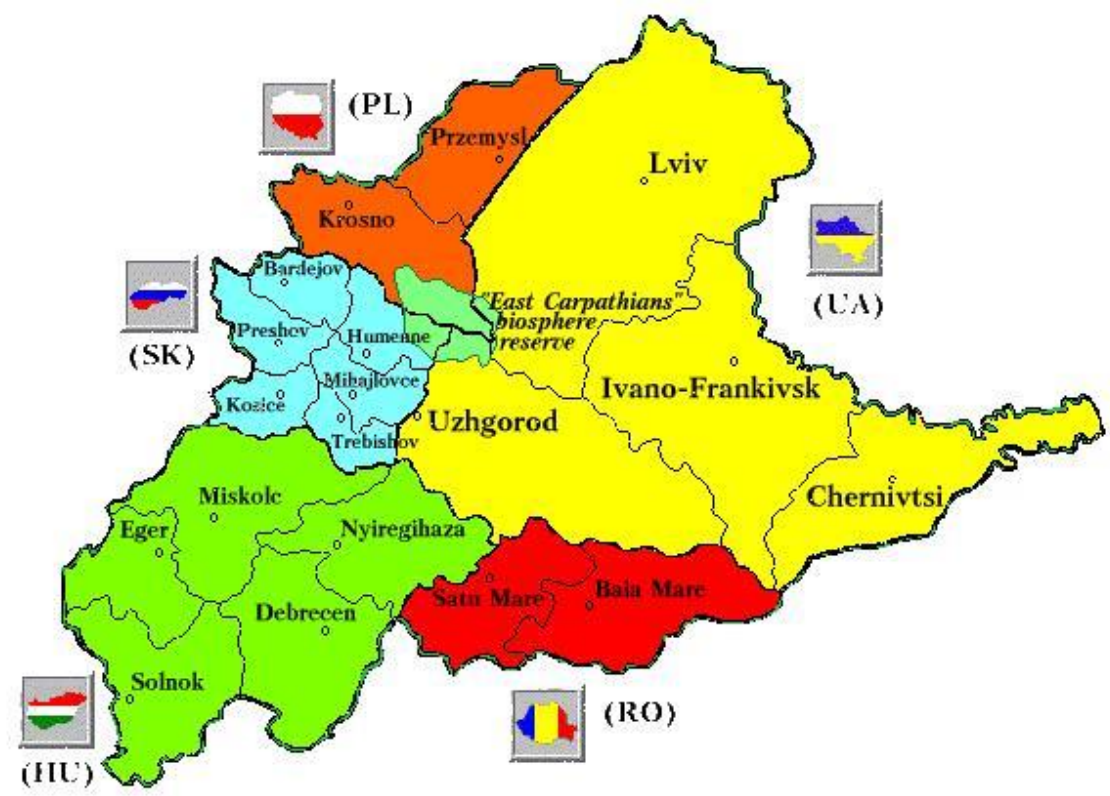

Figure 1.10. The map of the Euroregion "Carpathian Euroregion"

Sourse: retried by the authors from official website of the Euroregion "Carpatskyj", http://www.euroregionbug.com.ua

The border of the territory of Ukraine is also included in the Euroregion "Bug". The border regions of Ukraine and Poland became the parts of this Euroregion September, 29, 1995. Later the Euroregion "Bug" officially adopted the Brest region, which allowed to formalize legally the participation of the Belarusian side in the Euro region (Fig. 1.11).

There is an important fact that "Bug" is officially accepted into the Association of European Euroregions. This, of course, will contribute to increased focus on European countries to solve problems in these regions. Euroregions are one of the forms of cooperation 
of regional and local authorities, but at the same time they are the way of the harmonious integration of Belarus into the structure of modern Europe.

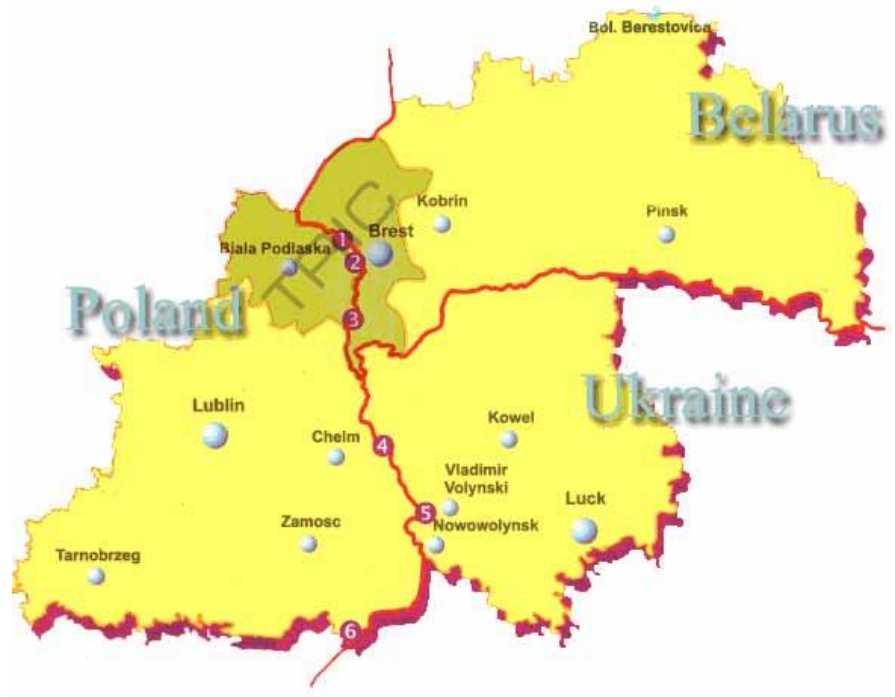

Figure 1.11. The map of the Euroregion "Bug"

Sourse: retried by the authors from official website of the Euroregion "Bug", http://www.euroregionbug.com.ua

Euroregion "Nyzhnij Dunaj" unites the border territory of Moldova, Romania and Ukraine. It was created on the initiative of the presidents of the three countries in 1996 and implemented by signing in February 1997 in Galati agreement on the establishment of the Euroregion "Nyzhnij Dunaj". On the Moldovan side it includes the districts of Cahul, Cantemir and Vulcanesht, on Rumanian - counties Galats, Tulcha and Krejla and Odessa region of Ukraine.

The Agreement on creation of the Euroregion "Verhnij Prut" was signed September, 22, 2000 in the Romanian city of Botoshany, it consisted of Chernivtsi region of Ukraine, Beltskyj and Edynetskyj counties of the Republic of Moldova, as well as Botoshansky and Suchavskyj counties of Romania.

Euroregion "Sloboda" was established on 7 November 2003 in Kharkiv by the leaders of executive authorities and local self-government of Kharkov and Belgorod regions of Ukraine and the Russian Federation respectively as the highest form of transboundary cooperation to harmonize the interaction of the parties for the implementation of basic social and economic functions in the borderlands, elimination of unnecessary barriers to the contacts of the population, bringing innovation and investment to stabilize and grow the economy, enhance interregional economic cooperation.

April 29, 2003 the company signed an agreement on establishment of transboundary Community Euroregion "Dniester", including Gomel region of the Republic of Belarus, Bryanska region of the Russian Federation, Chernihiv region of Ukraine. The founders of the Euroregion «Yaroslavna» are the Sumy region of Ukraine and Kursk region of the Russian Federation. The Euroregion "Dniester" includes one administrative-territorial unit of Ukraine (Vinnytsia region), three regional territorial units of Moldova (districts), and two district- 
owned Moldova, but are on the other side of the Dniester river (Fig. 1.12). The region occupies the territory of $34218 \mathrm{~km}^{2}$, with a population of more than two million people.

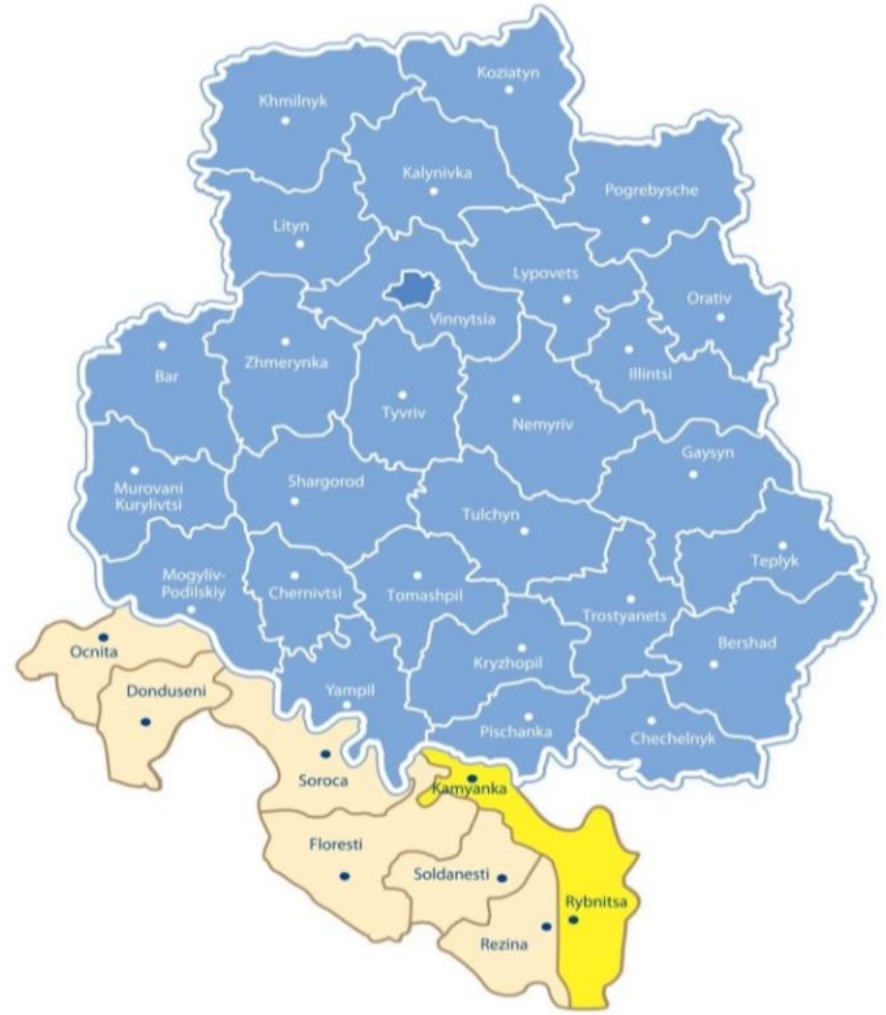

Figure 1.12. The map of the Euroregion "DNIESTER"

Sourse: retried by the authors from official website of the Euroregion "Dniester", http://www.dniester.eu/

The main purpose of creation and activity of the Euroregion "Dniester" is the implementation of sustainable development programs in the areas adjacent to the river Dniester. The region has a large number of unresolved issues on environmental protection, which include problems of storage and processing of waste, and ecological rehabilitation of the river basins of the Dniester and Pivdennyj Bug, namely: cleaning up rivers, coastal protection, and exploitation of hydropower and water treatment facilities, monitoring traffic loads.

Studennikov I. (2011) mentioned that in the Dniester basin there are a lot of nongovernmental environmental organizations of Ukraine and Moldova, whose efforts are aimed at improving the ecological status and water quality of the basin. For example, in Prydnistrovje there is now about 15 non-governmental environmental organizations, five resource information centers are created. Using the format of the Euroregion as a mechanism for strengthening the social economic development of the region, it became possible to raise the environmental problems of the Dniester river and crossing the Ukrainian-Moldovan border before the European Union and to receive constructive consent to the development of several projects.

In general, geographical map attraction of Ukrainian regions in the composition of the Euroregions has the following form (Fig. 1.13). 


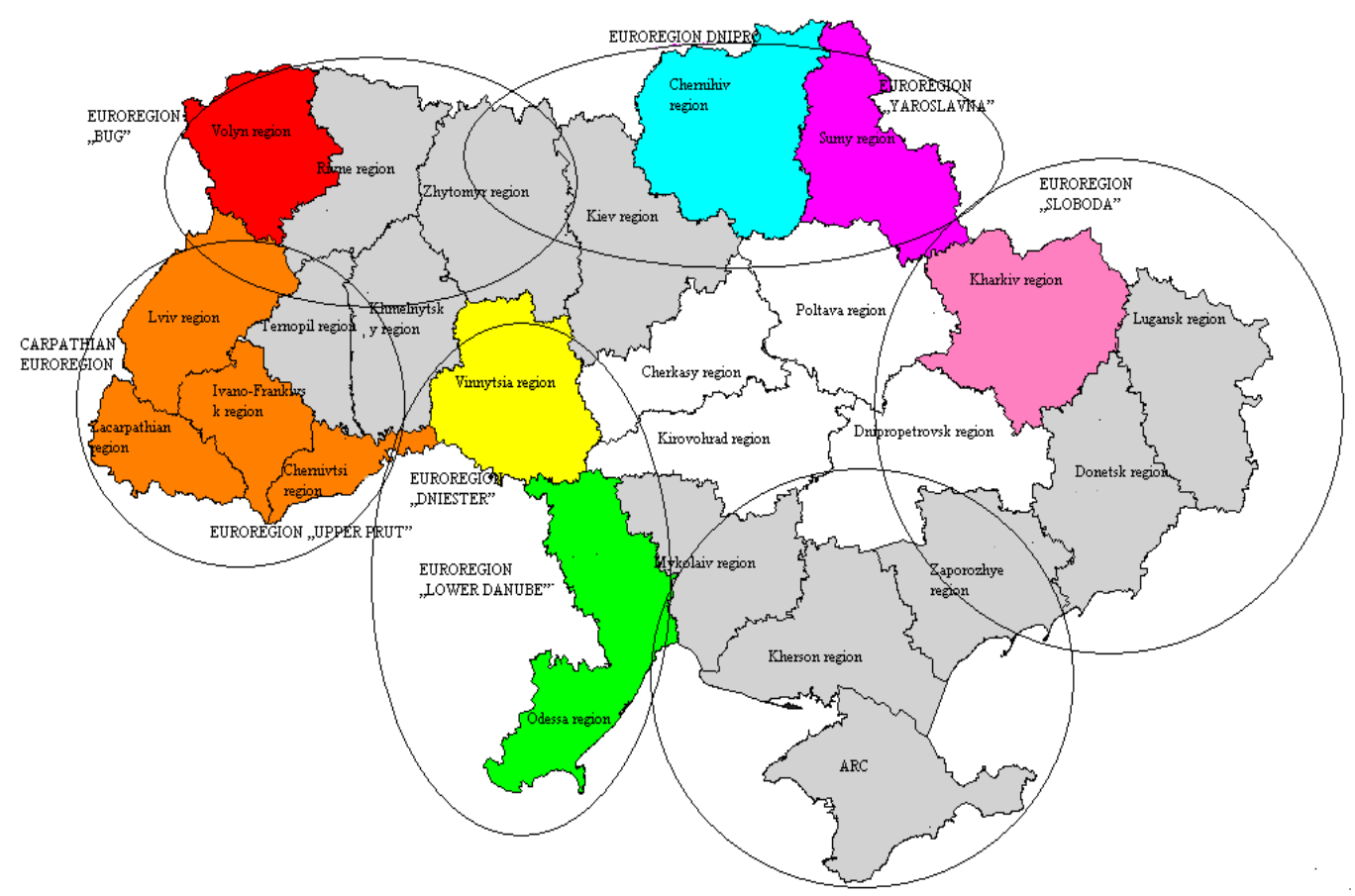

Figure 1.13. The map of joining of the regions of Ukraine to the Euroregions*

Sourse:compiled by the authors, based on Studennikov, 2011 and "Recommendation 296 "Sustainable development of mountain regions and the experience of the Carpathian mountains" of the Congress of local and regional authorities"

* gray colors sign the regions, which are proposed to be included in the composition of Euroregions for enhancing transboundary cooperation

The absence of including the interests and practices of transboundary cooperation as a form of realization of foreign economic activity of enterprises and companies of the territories of the neighbouring countries forms the general problems of development of border regions of Ukraine. Among them are the following:

- low level of social and economic development in comparison with other (central) regions, the peripheral nature of the economy;

- transboundary regions form the so-called "zone of potential political tensions";

- the distance from the domestic sources of regional security forms their focus on foreign economic cooperation, which makes them vulnerable to the dynamics of trade and economic relations of Ukraine with neighbouring countries (table 1.5);

- the discrepancy in the rate of development of foreign economic openness in the structural-economic (diversity of species and forms of foreign economic activity) and legal (the development of foreign economic activity of the region, the liberalization law) aspects in favor of the second one;

- the presence of such natural-climatic conditions, industrial structure, the similarity in cultural and ethnic relationship with the regions of neighboring countries, resulting the effective reproduction chain is created (for all factors) that also is in direct relation to the relations of the countries. 
Table 1.5. Scenarios of development of relations of Ukraine with neighbouring countries*

\begin{tabular}{|l|c|c|c|l|}
\hline Neighbouring country & $\begin{array}{l}\text { Dynamics of trade and } \\
\text { economic relations }\end{array}$ & Social factor & $\begin{array}{l}\text { Political } \\
\text { factor }\end{array}$ & Scenarios \\
\hline Russia & - & + & - & Pessimistic \\
\hline Belarus & - & + & - & Pessimistic \\
\hline Poland & + & + & + & Optimistic \\
\hline Slovakia & + & - & + & Neutral \\
\hline Hungary & + & - & + & Neutral \\
\hline Romania & + & - & + & Neutral \\
\hline Moldova & - & - & - & Pessimistic \\
\hline
\end{tabular}

Sourse: author's forecast based on the analysis of the dynamics of foreign economic activity of Ukraine

The above said allows us to hypothesize about the heterogeneity of the edge space of Ukraine for the degree of adaptability / involvement of border regions and their economic entities in the system of transboundary cooperation in the framework of the development of foreign trade exchanges, participation in international scientific and technical, industrial and investment cooperation, the use of transboundary provisions for social and economic development (increase gross of regional product (GRP) in general and for one person in particular), etc. In this regard, in our opinion, the development of transboundary cooperation with the Russian Federation, Belarus, and Moldova must be different from the directions of development of transboundary cooperation in the Western border regions of Poland, Slovakia, Hungary, and Romania. Assessing the effectiveness of financial and investment transboundary linkages of Euroregions in Ukraine, it can be argued that, despite the favorable geographic position, natural resources, skilled personnel, achievements in scientific research, a large capacity of the domestic market, the volume of foreign investments into the economics of the country is significantly lower than the volumes in Western Europe.

The development of transboundary cooperation in the framework of Euroregions are involved in Euro regions of Ukraine, due to financial problems and the various powers of local authorities in partner countries is very slow compared to the Euroregions, which are formed within the European Community. This can be seen in comparison with, for example, actively cooperation on the border of Switzerland, southern Germany and France, which form the area of regional cooperation in Upper Bavaria, in which there are two regional committees that monitor joint activities in the field of industry and ecology.

In Eastern Europe it is important that the Euroregions as a form of transboundary cooperation contribute not only to strengthening and deepening good-neighborly relations between countries, but they also are a kind of tool for the integration of the country into European structures. This is especially important for Ukraine in connection with the situation and the desire to be a member of the European Union. Euroregions sometimes explained as means of resolving possible territorial issues between two countries. They relieve tension in any territorial claims; allow solving the problems associated with the situation of national minorities. It is a kind of a testing ground for the compatibility of the legislation of different countries and legal systems.

International experience of transboundary cooperation testifies in favor of the fact that the large-scale relations between neighbouring territories are a common form of organization of foreign economic and other activities. However, contrary to the membership in the Euroregions, the majority of the German-Polish projects have failed in the quest for more effective partnership having difficulties at the Central offices of the Euroregions. As a result, the EU 
funds are often used as additional items of income, than go for the implementation of joint initiatives. Internal conflicts over the allocation of resources often prevent coordination of initiatives for regional development, intended for the border region. There is a complicated situation in almost all regions of the Euroregions, which include Ukraine, and it is easy to explain. The world practice of transboundary cooperation in the form of Euroregions provides interaction between equal partners. However, analysis of the existing economic relations suggests that numerous political declarations have not yet transformed into a new quality of economic relations. In Euroregions the simplest technological cooperation and transboundary trade dominate, which have the special character. For example, the experience of most European regions shows that the private sector is poorly represented in the transboundary cooperation and it's rather difficult to bring it to cooperation. Most experts indicate that today Euroregions are still far from achieving the goals. Despite generous subsidies, the real cooperation is provided only in some areas of interaction.

\section{References:}

Bila, O. (2013). The Euroregion "Carpatskyj" as a factor of European integration of Ukraine.Strategic priorities. No 3 (28). Available at: http://www.niss.gov.ua/public/File/Str_prioritetu/SP_3_2013.pdf

Chubaj-Fedorenko, G. (2012). Problems of transboarding cooperation of Ukraine in conditions of wide EU. International relations of Ukraine: sctentific researches and foundations. Iss. 21: Interdepartmental collection of scientific works, ed. by S. V. Vidnyanskyj. K.: Institute of history of Ukraine of NAN of Ukraine.

Cross-border cooperation. Strategy paper, 2007-2013 Indicative program 2007-2010. The Official website of the European Commission. Available at: http://ec.europa.eu.

Dubovik, B. (2011). The Experience of international cooperation in the framework of Euroregions.Prospects of Ukraine. Available at: http://www. uspishnaukraina.com.ua

Efficiency of transborder cooperation via international monitoring and coordination of activities of national subjects (2011).Proceeding of international scientific-practical conference (Uzhgprpd, April 8-9, 2011).

Official website of the Euroregion "Bug" Available at: http: http://www.euroregionbug.com.ua/ Official website of the Euroregion "Carpatskyj" Available at: http: http:/leuroregionkarpaty.com.ual

Official website of the Euroregion "Dniester" Available at: http: http://dniester.eu/

Optimization of transborder cooperation system: concept and its pilot application (2012). Uzhgorod: Bila.

Recommendation 296 "Sustainable development of mountain regions and the experience of the Carpathian mountains" of the Congress of local and regional authorities Available at: http://www.coe.int/T/Congress/Default_en.asp

Studennikov, I. (2006).Transboarding cooperation and its role in process of European integration of Ukraine. International relations of Ukraine: sctentific researches and foundations. Iss. 15: Interdepartmental collection of scientific works: ed. by S. V. Vidnyanskyj. $K$.: Institute of history of Ukraine of NAN of Ukraine.

The action program to improve transboundary cooperation and sustainable management in the basin of the Dniester river (2015). Available at: http://www.osce.org/ru/ukraine/104014?download=true

The law of Ukraine "On transboundary cooperation" (2004).Bulletin of the Verkhovna Rada of Ukraine 2004, No. 45. 


\title{
CHAPTER 2
}

\section{DECENTRALIZATION AND TERRITORIAL CONSOLIDATION IN UKRAINE AS NEW TRENDS IN GLOBAL PARTNERSHIP}

\subsection{GLOBAL PARTNERSHIP FOR LOCAL ECONOMIC DEVELOPMENT}

\author{
Daria Marushchak \\ PhD (Economics), Senior Lecturer of the International Economics and Business Department, \\ Cherkasy State Technological University, Cherkasy, Ukraine \\ Vladislav Pasenko \\ PhD (Economics), Associate Professor, \\ Associate Professorof the International Economics and Business Department, \\ Cherkasy State Technological University, Cherkasy, Ukraine
}

Sustained economic growth will require society to create conditions that will allow people to have quality jobs that stimulate the economy without harming the environment. This slow and uneven progress requires a rethinking of our economic and social policies aimed at eradicating poverty. A successful implementation of the sustainable development program requires a comprehensive partnership between governments, the private sector and civil society. These global, regional, national, and local levels require collaboration based on principles and values, a shared vision and common goals that are focused on the interests of mankind and the planet.

In 2015, world leaders approved the Sustainable Development Agenda for the period up to 2030, aimed at eradicating poverty, eliminating inequalities and combating climate change. To achieve the goals of sustainable development, all - governments, civil society, researchers, academia and the private sector - must act together. The agenda and its 17 goals in the area of sustainable development are common and call for action by all countries - both developed and developing countries. Ban Ki-moon, UN Secretary-General, says that for a successful implementation of the Sustainable Development Agenda for the period up to 2030, humanity must move from obligations to action without delay. This requires strong, comprehensive and comprehensive partnerships at all levels.

Therefore, one of the 17 goals of sustainable development, that promotes integration, the development of a comprehensive partnership at the global level and the creation of a single world economic and social space, are recognized the goal of "Partnership for Sustainable Development". The main task whose implementation is envisaged to achieve this goal is presented in table 2.1. The goal of global partnership is the last in the list of sustainable development goals, but it is not the last in significance, as it is the basis for other goals. It is thanks to international cooperation and partnership that we can overcome the imbalances in society (poverty, hunger, etc.), improve the environment, save resources and protect the planet for the future generation. The Global Partnership is a form of constructive dialogue between different communities that are sometimes in confrontational relationships. The basis of such relations can be a set of factors, which include the difference in the system of religious, political, economic, cultural, and even moral values (Voitovich R.V., 2013). 
Table 2.1 The basic tasks for the achievement of global partnership

\begin{tabular}{|c|c|}
\hline № & Table of contents \\
\hline 1 & $\begin{array}{l}\text { To Strengthen the mobilization of resources from internal sources, including due to } \\
\text { international support of countries that develop, for the increase of national possibility in } \\
\text { relation to tax and other acuestss collection }\end{array}$ \\
\hline 2 & $\begin{array}{l}\text { To ensure that developed countries fully fulfill their Official Development Assistance } \\
\text { (ODA) commitments, including the commitment by many developed countries to achieve } \\
\text { the target of } 0.75 \text { billion SDF allocation to developing countries the percentage of its gross } \\
\text { national income (GNI) and the allocation of ODR to the least developed countries at the } \\
\text { level of } 0.15-0.20 \text { per cent of its GNI }\end{array}$ \\
\hline 3 & $\begin{array}{l}\text { To mobilize additional financial resources from the most various sources for developing } \\
\text { countries. }\end{array}$ \\
\hline 4 & $\begin{array}{l}\text { To give developing countries, help with the aim of providing of long-term acceptability of } \\
\text { level of their debt due to realization of the скоординованої politics sent to encouragement, } \\
\text { depending on circumstances, debt financing, facilitation of promissory load and } \\
\text { restructuring of debt, and also to decide the problem of external debt of poor countries with } \\
\text { a large debt, to facilitate them promissory load. }\end{array}$ \\
\hline 5 & $\begin{array}{l}\text { To accept and apply the modes of encouragement of investments in interests of the the least } \\
\text { developed countries }\end{array}$ \\
\hline 6 & $\begin{array}{l}\text { To extend a collaboration for lines North-south and South-south, and also trilateral regional } \\
\text { and international collaboration in the areas of science, technique and innovations and access } \\
\text { to the corresponding achievements; to activate the exchange of knowledge on the mutually } \\
\text { concerted terms, including due to the improvement of co-ordination between existent } \\
\text { mechanisms, in particular at the level of United Nations, and also by means of global } \\
\text { mechanism of assistance to the transmission of technologies. }\end{array}$ \\
\hline 7 & $\begin{array}{l}\text { To assist development, transmission, distribution and mastering ecologically of safe } \\
\text { technologies, that they were got by countries that develop, on the mutually concerted } \\
\text { favourable terms, including on the favourable and преференційних terms }\end{array}$ \\
\hline 8 & $\begin{array}{l}\text { To provide the full-scale functioning of bank of technologies and mechanism of } \\
\text { development of science, technologies and innovations in interests of the the least developed } \\
\text { countries and extend the use of high-efficiency technologies, in particular of informatively- } \\
\text { communication technologies }\end{array}$ \\
\hline 9 & $\begin{array}{l}\text { To strengthen international support of effective and purposeful increase of potential of } \\
\text { countries for an assistance to realization of national plans of achievement of all aims in the } \\
\text { field of steady development, including due to a collaboration for lines North-south and } \\
\text { South-south and trilateral collaboration }\end{array}$ \\
\hline 10 & $\begin{array}{l}\text { To encourage universal, rule-based, undiscriminatory and just multilateral trade open } \\
\text { system within the framework of World organization of trade, including due to completion of } \\
\text { negotiations within the framework of the Doha order-paper in the field of development. }\end{array}$ \\
\hline 11 & $\begin{array}{l}\text { Significantly increase exports from developing countries, in particular, in order to double } \\
\text { the share of the least developed countries in world exports by } 2020\end{array}$ \\
\hline 12 & $\begin{array}{l}\text { To ensure the timely provision of long-term duty-free and non-quota-based access to } \\
\text { markets for the least developed countries in accordance with the decisions of the World } \\
\text { Trade Organization, including by ensuring that preferential rules of origin applicable to } \\
\text { goods imported from the least developed countries are transparent and simple. and } \\
\text { facilitated access to markets }\end{array}$ \\
\hline
\end{tabular}

Source: compiled by the authorsaccording to: http://www.un.org.ua/ua/tsili-rozvytkutysiacholittia/tsili stalohorozvytku 
The most important transformation is the formation of a new spirit of solidarity, cooperation and mutual responsibility - the principles upon which the agenda for the post 2015 period should be based. The new global partnership should be based on the general understanding of all people affinity, with the awareness of the need for mutual respect and mutual help in this. Global partnership should include not only the activities of governments, but also the participation of all members of society, non-governmental organizations, international organizations, local governments, business communities, academic institutions, private charitable foundations, etc.

According to "New global partnership: poverty eradication and economic transformation through sustainable development " by UN, each priority sphere of public life should be supported by dynamic partnership relations based on new mechanisms and ways of interaction and responsibility of each participant. In "Communique of the High-Level Group" (2013) mentioned that g lobal partnership should be based on the principles of equality, balance, solidarity, respect for the person and universal responsibility in accordance with the capabilities of each. For mutual support in times of crisis, for the exchange of technologies, innovations and other technical skills and resources, mutually beneficial partnerships on the basis of cooperation and cooperation are extremely necessary for the development of fair and transparent world relations. A partnership in pursuit of sustainable development goals is a guarantee that nobody will be forgotten. Both existing and additional resources need to be mobilized in the field of technical development, finance, capacity-building, and developed countries will have to fulfill their official development assistance commitments. Multilateral partnership will be important to optimize the links between sustainable development goals in order to increase their efficiency and effectiveness and to accelerate progress towards these goals (Fig. 2.1).

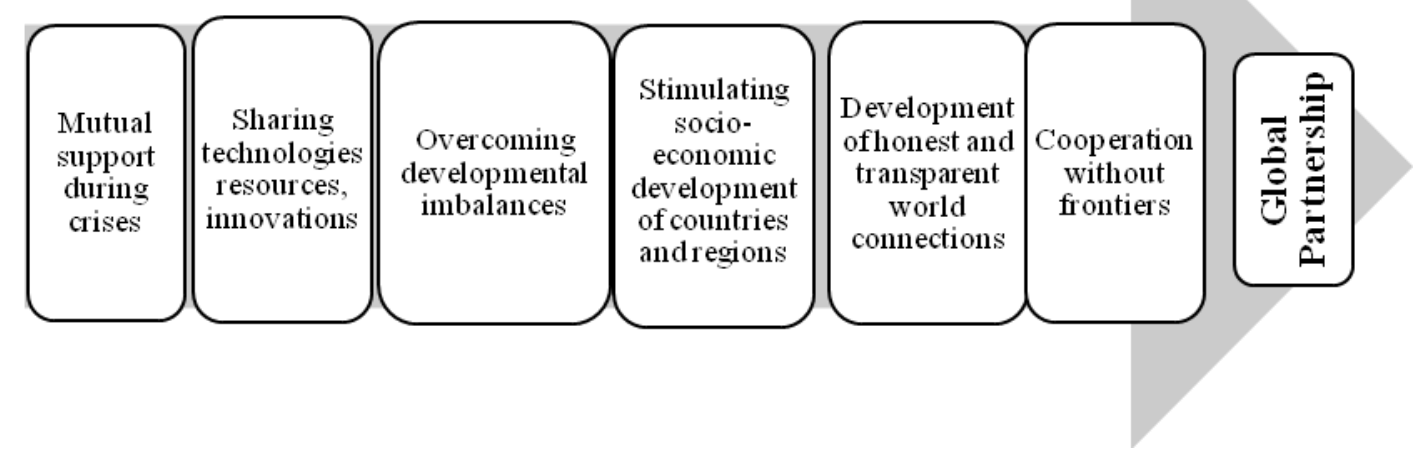

\section{Figure 2.1. The system of basic characteristics of the global partnership}

Through the development of the global partnership, official development assistance to countries for development in 2014 was 135.2 billionUSD, the highest level of assistance recorded at any time. To achieve this goal, humanity has made 79 percent of imports from developing countries to developing countries free of charge. The debt burden for developing countries remains stable at around 3\% of export earnings, which is very important at this stage of the world development, as a stable percentage helps to plan on a plan and directs most of the vectors for development rather than repayment of debt obligations. 
It is now extremely important to take urgent measures to mobilize, redirect and unlock the transformational capacity of trillions USD of private resources to achieve the goals of sustainable development. Long-term investments, including foreign direct investment, require the following industries: energy, infrastructure and transport, as well as information and communication technologies, especially in developing countries. The public sector will need to establish a clear direction. Restrictions, rules and incentive structures for revision and monitoring that allow for such investments must be transformed to attract more investment and strengthen sustainable development. National oversight mechanisms, such as the highest authorities and public oversight bodies, need to be strengthened. Regular reviews of progress with the participation of civil society, business and representatives of various interest groups should be held in each country. At the regional level, countries will share experiences and address common issues, while in the United Nations, during the annual political forum, the global level, on sustainable development will be able to assess progress at the global level, identify gaps and new perspectives and issues, and recommend corrective actions. In the framework of the study of the issue of global partnership on the example of Ukraine, it would be advisable to consider the dependence of the regions in the world economic complex. The global partnership also involves monitoring of the developing countries progress and determining their competitiveness as well as the ability to be a player on the world market.

The involvement of Ukraine's regions in world affairs fully influences its economic and social development indicators. During the analysis, it is proposed to determine the country's involvement in the world economic complex by an author index - I cawec (index of country's attraction to the world economic complex):

$$
\mathrm{I}=\left(\left(\mathrm{E}_{\mathrm{m}}+\mathrm{I}_{\mathrm{m}}\right) / \mathrm{GRP}+\left(\mathrm{E}_{\mathrm{s}}+\mathrm{I}_{\mathrm{s}}\right) / \mathrm{GRP}\right)+\left(\mathrm{DFI}_{\text {in }}+\mathrm{DFI}_{\text {out }}\right) / \mathrm{GRP}
$$

where $\mathrm{E}_{\mathrm{m}}-$ export of goods from the region; $\mathrm{I}_{\mathrm{m}}-$ import of goods from the region; $\mathrm{E}_{\mathrm{s}}-$ export of services from the region; $\mathrm{I}_{\mathrm{s}}-$ import of services from the region; GRP - gross regional product; $\mathrm{DFI}_{\mathrm{in}}-$ foreign direct investment in the region; $\mathrm{DFI}_{\text {out }}{ }^{-}$foreign direct investment from the region.

According to report of State Statistics Service of Ukraine, in 2015 Ukraine carried out foreign trade in goods with partners from 217 countries of the world. Exported goods were up to 191 countries, imported - from 201 countries. Exports of goods in 2015 amounted to 38.1 billion USD, it decreased by $29.3 \%$ against the volume of 2014 and by $38.8 \%$ against the volume of 2013, imports of goods - by USD 37.5 billion, and decreased by $31.1 \%$ and $50.5 \%$ respectively. The positive balance of foreign trade in goods amounted to 0.6 billion USD (negative in 2013 - 13.5 billion USD). The most active was the export-import operations of the enterprises of Kyiv, Dnipropetrovsk, Donetsk, Kiev, Zaporozhye, Odesa, Lviv, Kharkiv and Poltava regions.

Ukraine's foreign trade operations with services in 2015 were carried out with partners from 220 countries of the world. Resident companies of Ukraine provided services to nonresidents of 214 countries, received from non-residents of 191 countries. Exports of services in 2015 amounted to 9.7 billion USD and are decreased by $15.5 \%$ against the volume of 2014 and by $31.6 \%$ against 2013, imports of services -5.5 billion USD, and decreased by $13.3 \%$ and by $26.6 \%$ in accordance. The positive balance of foreign trade in services amounted to 4.2 billion USD (in 2013 it is also positive -6.7 billion USD).

Exports of services in 2016 decreased by $19.5 \%$ - from 12.3 billion USD in 2008 to 9.9 billion USD. The United States for 2016, which is $19.3 \%$ of the total volume of Ukrainian 
exports. Exports of services are mainly provided by transport services $(53.7 \%$ of exports of services in 2016), of which about $49.1 \%$ are for the transportation of natural gas and oil, due to which Ukraine remains their non-exporter. Imports of goods have declined significantly in recent years and amounted to 39.2 billion USD in 2016, compared to 85.5 billion USD in 2008. This decrease was due to a number of reasons, including weak production activity, a decline in real incomes and a reduction in domestic demand, devaluation of the hryvnia, and the introduction of a temporary additional import duty.

The number of foreign investments in the regions of the country and regions during the analyzed period 2014-2016 has certain steady imbalances. Investments are distributed indifferently in connection with different resource availability and political situation in the country. The period of 2014-2016 was chosen to calculate the index. The research was conducted in thirteen regions of Ukraine, which were selected by the author in order to analyze the regions with different geographic locations, different resource provision and differentiated levels of infrastructure development. Output data is presented in table $2.2 \& 2.3$.

Table 2.1. Output data for calculating the author's index (2.1)

\begin{tabular}{|c|c|c|c|c|c|c|c|c|c|}
\hline \multirow{2}{*}{\begin{tabular}{|c|} 
Indicators \\
Pegion \\
\end{tabular}} & \multicolumn{3}{|c|}{ GRP, mln. USD } & \multicolumn{3}{|c|}{$\begin{array}{l}\text { FDI in regions of Ukraine, } \\
\text { mln. USD }\end{array}$} & \multicolumn{3}{|c|}{$\begin{array}{l}\text { FDI from regions of } \\
\text { Ukraine, mln. USD }\end{array}$} \\
\hline & 2014 & 2015 & 2016 & 2014 & 2015 & 2016 & 2014 & 2015 & 2016 \\
\hline \begin{tabular}{l|} 
Vinnytsya \\
Region
\end{tabular} & 1679.6 & 2286.0 & 2841.2 & 309.4 & 223.0 & 187.8 & 0.2 & 0.1 & 0.1 \\
\hline $\begin{array}{l}\text { Dnipropetrov } \\
\text { s'k Region }\end{array}$ & 6740.7 & 8217.1 & 9334.8 & 8913.0 & 5775.8 & 4009.9 & 199.3 & 115.5 & 71.9 \\
\hline \begin{tabular}{|l|} 
Donets'k \\
Region
\end{tabular} & 4581.3 & 4391.4 & 5250.1 & 3789.1 & 2322 & 1748.0 & 5980.8 & 5947 & 5940 \\
\hline $\begin{array}{l}\text { Zaporizhzhya } \\
\text { Region }\end{array}$ & 2518.8 & 3400.6 & 3983.3 & 1075.3 & 843.4 & 682.7 & 48.1 & 34.0 & 25.0 \\
\hline Kyiv Region & 3037.8 & 3972.1 & 4911.7 & 1951.5 & 1750.3 & 1593.4 & 7.3 & 0.7 & 0.9 \\
\hline $\begin{array}{l}\text { Kirovograd } \\
\text { Region }\end{array}$ & 1098.1 & 1468.0 & 1757.2 & 147.1 & 70.6 & 52.5 & 0.1 & 0.1 & 0.0 \\
\hline $\begin{array}{l}\text { Luhans'k } \\
\text { Region }\end{array}$ & 1198.7 & 910.6 & 1197.3 & 826.4 & 578.2 & 443.9 & 11.6 & 10.3 & - \\
\hline Lviv Region & 2784.4 & 3615.5 & 4385.0 & 1379.5 & 1197.7 & 1101.0 & 43.8 & 38.1 & 34.5 \\
\hline $\begin{array}{l}\text { Mykolayiv } \\
\text { Region }\end{array}$ & 1352.0 & 1840.2 & 2207.5 & 282.8 & 228.9 & 212.8 & 0.8 & 0.8 & 0.8 \\
\hline Odesa Region & 2861.2 & 3809.1 & \begin{tabular}{|l|}
4574.3 \\
\end{tabular} & 1671.7 & 1430.4 & 1330.1 & 37.4 & 29.5 & 18.7 \\
\hline \begin{tabular}{|l|} 
Poltava \\
Region
\end{tabular} & 2666.3 & 3660.4 & 4439.6 & 1064.7 & 1039.4 & 1000.1 & 3.4 & 2.6 & 1.8 \\
\hline Sumy Region & 1160.6 & 1587.1 & 1767.4 & 422.7 & 263.3 & 199.1 & 3.8 & 2.5 & 2.0 \\
\hline \begin{tabular}{|l|} 
Kharkiv \\
Region
\end{tabular} & 3688.3 & 4766.8 & 5913.4 & 2131.9 & 1728.8 & 1554.6 & 18.4 & 13.6 & 10.3 \\
\hline $\begin{array}{l}\text { Kherson } \\
\text { Region }\end{array}$ & 887.7 & 1230.0 & 1479.3 & 275.2 & 208.2 & 211.0 & 0.1 & 0.1 & 0.1 \\
\hline Kyiv & 13645.6 & 17247 & 21349.4 & 25825.6 & 20105.5 & 19296.0 & 334.7 & 250.2 & 190.1 \\
\hline
\end{tabular}

Source: compiled by the authors based on reports of State Statistics Service of Ukraine, av. at https://ukrstat.org/uk 
To calculate the selected indicators, which, in the opinion of the author that most clearly reflects the development of the region and its activity during foreign economic operations (gross regional product, direct investment in the country's regions, foreign direct investments from the country's regions to the countries world, exports, imports of goods and services across regions). Based on the selected data, we calculated the author's index, the results of the calculations are given in table 2.3.

During the 2014-2016 period, the regions of Ukraine hold relatively stable positions, the five leaders include the 5 most integrated and active regions: Kyiv, Donetsk, Lugansk, Dnipropetrovsk and Mykolaiv regions, with the index value fluctuating within 5 in 2014, and within 3 in 2016, demonstrating the decline of regional integration into the world economy. It can be caused by the volatile political situation and the frequency with which the national economy is housed, which is not sufficiently focused on the development of regions as such in times of crisis.

Table 2.3 Ranking of regions of Ukraine according to the calculated index of involvement of the global economic complex

\begin{tabular}{|l|l|l|l|l|l|}
\hline \multicolumn{2}{|c|}{ re14 } & \multicolumn{2}{c|}{ 2015 } & \multicolumn{2}{c|}{2016} \\
\hline region & index & \multicolumn{1}{c|}{ region } & index & \multicolumn{1}{c|}{ region } & index \\
\hline Kyiv & 4.69 & Donets'k Region & 3.13 & Luhans'k Region & \\
\hline Donets'k Region & 4.61 & Kyiv & 2.82 & Donets'k Region & 2.45 \\
\hline $\begin{array}{l}\text { Dnipropetrovs'k } \\
\text { Region }\end{array}$ & 3.45 & $\begin{array}{l}\text { Dnipropetrovs'k } \\
\text { Region }\end{array}$ & 1.97 & Kyiv & 2.29 \\
\hline Luhans'k Region & 3.37 & Kyiv Region & 1.61 & $\begin{array}{l}\text { Dnipropetrovs'k } \\
\text { Region }\end{array}$ & 1.49 \\
\hline Kyiv Region & 2.69 & Mykolayiv Region & 1.58 & Mykolayiv Region & 1.38 \\
\hline $\begin{array}{l}\text { Zaporizhzhya } \\
\text { Region }\end{array}$ & 2.66 & $\begin{array}{l}\text { Zaporizhzhya } \\
\text { Region }\end{array}$ & 1.50 & Kyiv Region & 1.36 \\
\hline Mykolayiv Region & 2.42 & Luhans'k Region & 1.40 & Odesa Region & 1.10 \\
\hline Odesa Region & 2.38 & Odesa Region & 1.36 & 3anopi3ький & 1.06 \\
\hline Lviv Region & 2.05 & Lviv Region & 1.19 & Lviv Region & 1.05 \\
\hline Poltava Region & 1.72 & Kharkiv Region & 0.99 & Poltava Region & 0.78 \\
\hline Kharkiv Region & 1.70 & Poltava Region & 0.97 & Kharkiv Region & 0.75 \\
\hline Sumy Region & 1.56 & Sumy Region & 0.87 & Sumy Region & 0.70 \\
\hline Kirovograd Region & 1.12 & Vinnytsya Region & 0.62 & Vinnytsya Region & 0.55 \\
\hline Kherson Region & 0.97 & Kherson Region & 0.51 & Kherson Region & 0.45 \\
\hline Vinnytsya Region & 0.93 & Kirovograd Region & 0.43 & Kirovograd Region & 0.41 \\
\hline Sorre: develop & & & & \\
\hline
\end{tabular}

Source: developed by the authors

The index of value below 1 has 6 regions that are outsiders in the investigated aspect during the last two periods (Poltava, Kharkiv, Sumy, Vinnitsa, Kherson and Kirovograd regions). To some extent, such indicators are due to the lack of proper investment and differentiated state policy of regional development.

Global partnership, as a program of action, in turn helps to combat developing countries with disproportions in development, primarily regional, as outlined above. Donor countries during the financial assistance are highly developed countries focused on achieving sustainable development of the world environment. 


\title{
References
}

Communique of the High-Level Group, Bali, March 27, 2013. Available at: http://www.post2015hlp.org/wp-content/uploads/2013/03/Final Communique-Bali.pdf

New global partnership: poverty eradication and economic transformation through sustainable development. Available at: http://www.un.org/ru/sg/ management/ hlp_report_ru.pdf].

State Statistics Service of Ukraine Available at: https://ukrstat.org/uk

The United Nations in Ukraine. Available at: http://www.un.org.ua/ua/tsili-rozvytkutysiacholittia/tsili stalohorozvytku

Voitovich, R.V. (2013). New Context of Global Political Restructuring in the World: Axiological Analysis. Institute of Political and Ethnonational Studies named after. I. F. Kuras]. Vol. 2, 520-539. Available at: http://nbuv.gov.ua/UJRN/Nzipiend-_2013_2_36.

\subsection{DECENTRALIZATION IN THE SYSTEM OF REGIONAL SOCIO-ECONOMIC DEVELOPMENT PREREQUISITES: INTERNATIONAL EXPERIENCE FOR UKRAINE}

\author{
Lesya Petkova \\ Doctor of Economics Sciencies, Professor, \\ Head of the International Economics and Business Department, \\ Cherkasy State Technological University, Cherkasy, Ukraine
}

The processes of decentralization, launched in Ukraine in 2014 due to the adoption of a number of laws in accordance with the provisions of the European Charter of local selfgovernment, are designed to ensure the modernization of public administration, lay the foundations for the effective local government, the conditions for improving livingstandards of the society. The transfer of parts of competences and resources of financial security at the level of local communities forms motivation and helps achieve a sustainable development at the local level. The focus of the management efforts on the local development leads to the diversification and strengthening of the interaction of economic and social activities at the level of an individual territory through the mobilization and coordination of existing and potential resources.

The decentralization reform is aimed at the solution of the key tasks of the regional economic development - increasing the number of high paying jobs, strengthening of the competitive positions in the region, the use of inter-regional differences to improve the level of living standards, reducing territorial imbalances. The main task of the reform is the liability increase of the local community members, as a long-term outcome and effectiveness of the reform will be determined precisely by the civil society activity.

Three years of reform implementation has brought tangible financial results. Thus, the revenues of local budgets increased by 2.8 times to 68.7 billion UAH in 2014 to 192.7 billion UAH in 2017, the amount of income tax on incomes of physical persons per inhabitant increased by $23.9 \%$ (up to $2510.4 \mathrm{UAH}$.) local taxes and fees per person increased by $16.7 \%$ (1265.3). By the end of 2017 the share of local budgets in revenues of a consolidated budget of Ukraine constituted 51.2\% (Financial decentralization: results and perspectives report, 2017). Improvement in financial and fiscal capacity of local and regional development is the key to enhancing the potential growth of territories. Communities build the list and increase the quality 
of services to residents, implementing infrastructure projects for the development of entrepreneurship, increase the investment attractiveness of the territories.

In Ukraine there are decentralization region-leaders on the scale created by unified territorial communities - the Zhytomir region (55.8\% of the region territory), Dnipropetrovsk (53.4\%), Zaporizhzhya (57.0\%), Khmelnitsky (53.5\%). A proportional growth of the involved communities is important for the further promotion of the reform. According to the decentralization reform plan 1.5-1.8 thousand united communities against 733 as of May, 2018, must be created in Ukraine.

The results of financial monitoring of decentralization processes of 2014-2017 in Ukraine, provided by the experts of the Central reform office of the Ministry of regional development, show the growth of own revenues of local budgets during the study period, in general at 124 billion UAH. In 2017 the amount of financial resources available to local authorities for the first time was $51.2 \%$ of the consolidated budget of the country. The unified territorial communities (UTC) have much better development results. Own revenues of local budgets of 366 UTC for the period of 2017 increased by $87 \%(+4.3 \mathrm{bln}$. UAH) and constituted 9.3 billion UAH. The growth rate of own revenues of 159 UTC, which in 2016 received in their budgets $60 \%$ of the tax to incomes of physical persons amounted to $34.2 \%$, which is $3 \%$ higher than the average in Ukraine. The growth of the financial viability of local budgets must lead to the formation of balances as of the January, 01 of a new year. In 2018 this amount was 55.7 billion UAH (Financial decentralization: results and perspectives report, 2017).

The financial results of the reform indicate the existence of problems arising in the process of its implementation. Thus, the expanded authority of heads of UTCs due to lack of knowledge and experience is often incomprehensible for them. The management of the educational sector, taxes, organization of tenders, participation in international projects and other issues of current activities of UTC require a professional decision, taking into account both the achievements of decentralization in the leading regions of Ukraine and the best international experience. The lack of skills and training employees must be solved. Consequently, a new system of training and qualification require a professional development and implementation.

Understanding and support of a state policy by the society are important for the decentralization reform success, improvement of people's living standards, improving the quality of public services Sociological studies conducted by KMIS and Center "Social indicators" by order of the Council of Europe Programme "Decentralization and territorial consolidation in Ukraine", reflected the growth of awareness and confidence of citizens in the reform. If in $2015,19 \%$ of the population of the united territorial communities (UTC) noted positive changes in their lives under the influence of decentralization, in 2017 this figure rose to $43 \%$. Further development of separate territorial communities, strengthening of their financial capability and motivation to development include the changing socio-economic priorities with the specific public policy established at the local level. This task involves the organization of local communities, social groups on solving important social tasks to mobilize primarily local resources. Activation of the economic growth factors at the local level suggests the diagnosis of the territory potential, allocation of tools to ensure the economic development, the formation of an effective system of making and implementing of management decisions. The sustainable local development, thus, integrates not only the purely economic effects of the new products and services growth, but ensures the implementation of other social needs - intangible, social, cultural.

The reform of the power territorial organization in Ukraine still has a limit of passivity of a significant part of society. The reasons for this, primarily, are the lack of understanding of the 
importance and effectiveness of reforms, lack of understanding of the territorial development management system in modern realities of the power distribution. The chronic distrust to the government in general, due to the periods of substantial deterioration of living conditions, leads to the traditional civic passivity. Meanwhile, the objective strengthening in the financial capacity of territorial communities as a result of the reforms requires an active involvement of residents in issues of control and the resources allocation.

Allen-Dupre D. (2017) mentioned that decentralization experience of the developed countries shows the significant impact on the economic growth, in the first place, the decentralization of revenues. Unitary states, local authorities with own revenues primarily benefit from the tax decentralization and better meet the needs of the local population, promoting social and economic efficiency. Overall, the success of the regional development in the context of decentralization is defined in the broad political context, functioning of a qualitative institutional framework which determines the activities of regional authorities and the local self-government. The level of decentralization in the cross-country aspect is rather differentiated. The group of developed countries, in general, has a high level of decentralization. Thus, according to the financial component with the world average value of the share of subnational government expenditures on the overall level of government spending of $24 \%$ in the OECD countries this figure is $40 \%$ (Allen-Dupre D., 2017).

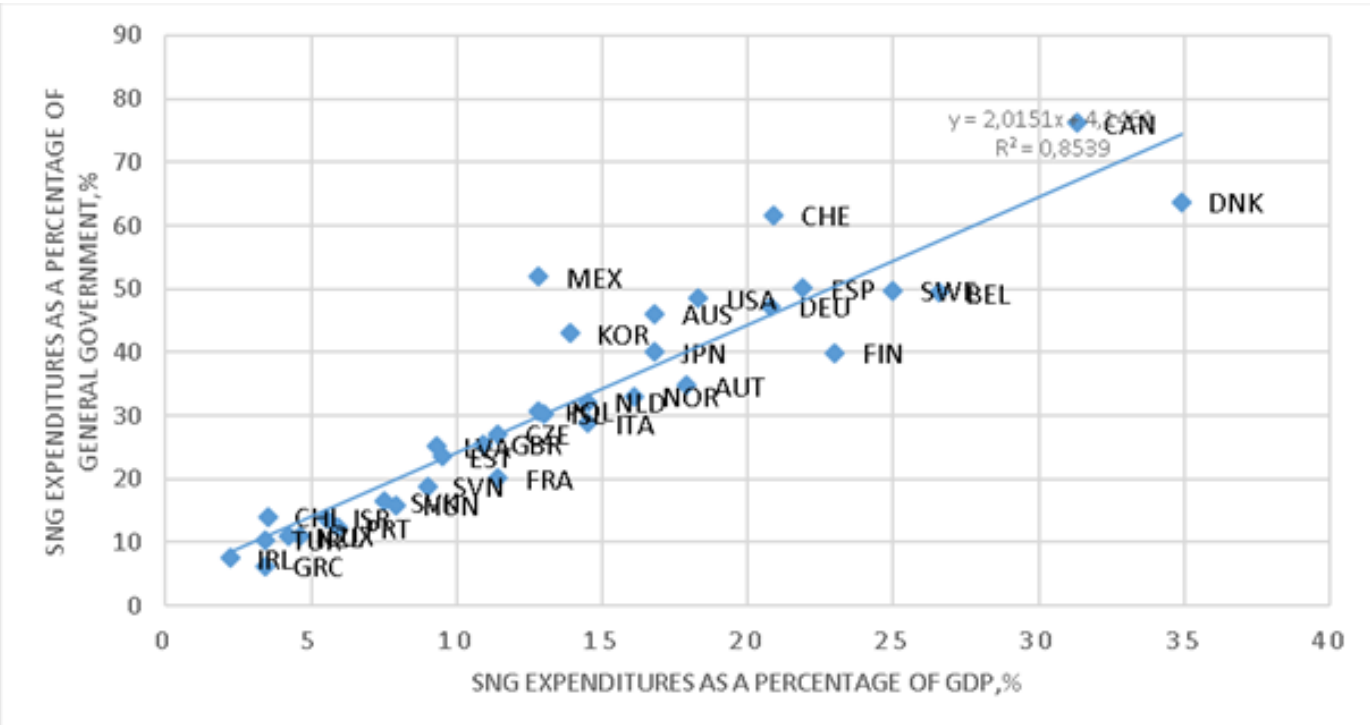

Figure 2.2. Decentralization level of in OECD countries

Source: compiled by author based on the data of Subnational Government Structure and Finance Report, https://stats.oecd.org/Index.aspx?DataSetCode=SNGF

There are also significant differences in the ratio of the share of subnational government expenditures in national expenditures and their share in GDP. If the first indicator among OECD countries with federal or quasi-federal structure is an average of $19.2 \%$ (2015), among unitary countries (the average is 12.6 percent), the situation is much more differentiated. Thus, the share of total expenditures of the sub-national government in GDP in OECD countries in 2015 changed from $2.2 \%$ in Ireland and 3.4\% in Greece and Turkey, 3.5\% in Chile to $16.1 \%$ in Norway, $16.8 \%$ in Japan, 23\% in Finland, 25\% in Sweden, 34,8\% in Denmark. Also the 
countries significantly differ by the share of subnational government expenditures in the total public expenditure. In countries with a federal structure the average value is $50 \%$ (maximum, Canada-76.2\%), in UTC it is accounting for $28.7 \%$ (minimum, Greece - 6.2\%), Fig. 2.2.

Taking OECD countries as an example, we note that the direct dependence of the level of expenditures of sub-national governments with the level of economic development of countries is not observed. However, it is advisable to allocate two groups of countries with substantial differences in the financial indicators of differentiation and the level of income per capita. So, with the expenditure of subnational governments in GDP to $15 \%$, the level of per capita income did not exceed 40 thousand USD USA. - in Mexico, Chile, the Czech Republic, Estonia, Greece, Hungary, Latvia, New Zealand, Portugal, Slovakia, Slovenia, Turkey etc. Another group of countries, where the share of subnational governments' expenditure in GDP amounted to $15-35 \%$ has the average income per capita 40-65 thousand USD. USA. It is Denmark, Belgium, Canada, Sweden, Finland, Germany, the USA, Norway, Austria, Australia, Japan, Switzerland (Fig.2.3).

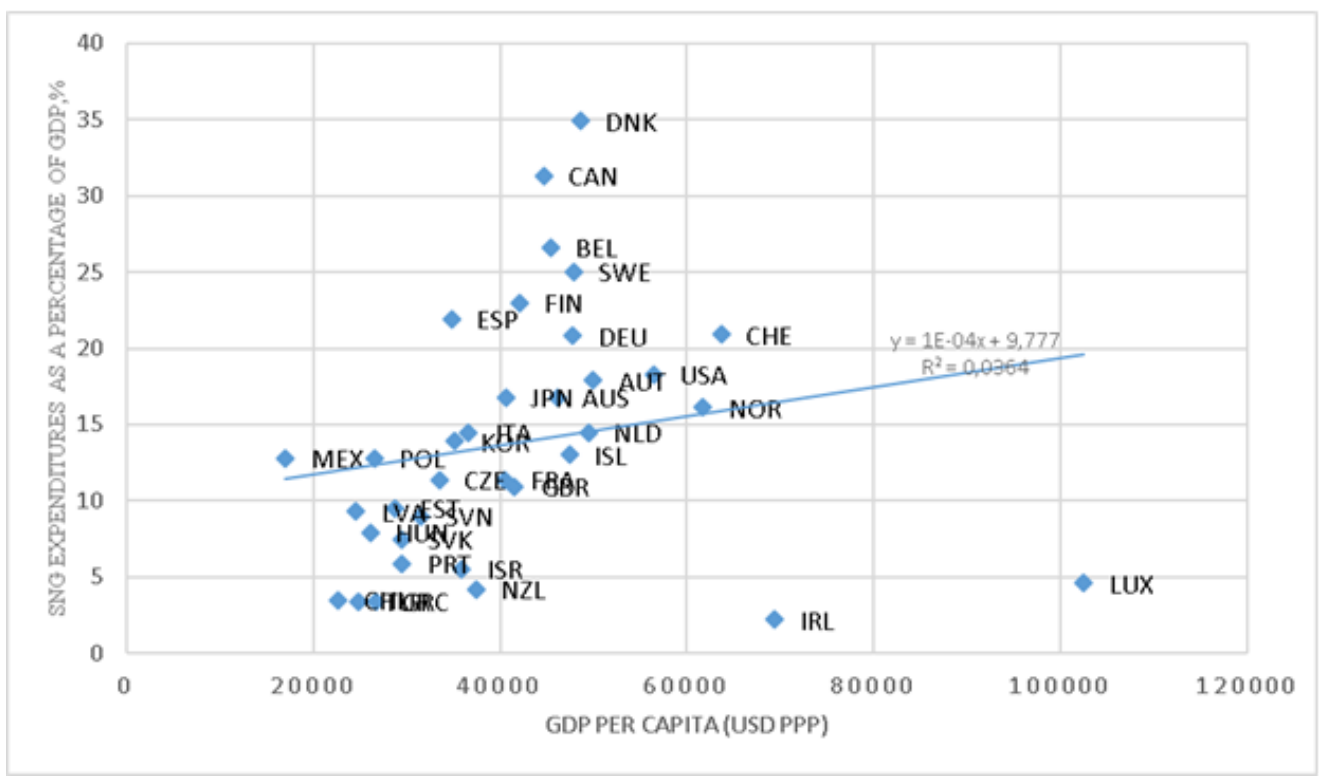

Fig. 2.3. Decentralization and economic development in OECD countries

Source: compiled by author based on the data of Subnational Government Structure and Finance Report, https://stats.oecd.org/Index.aspx?DataSetCode=SNGF

The research of the relationship between decentralization and economic growth in OECD countries, in the context of a business activity, productivity and investment processes, conducted by Rodríguez-Pose A. and Krøijer A. (2009) proves their high interdependence. The decentralization, especially its financial component, directly affects the activities of economic agents that is firms, households, public institutions. The decentralization largely determines the way of savings and investments, the pace of investment. It defines the prospects for a long-term economic growth of regional economic systems and countries in general. Fiscal decentralization has an especially significant influence on the basic indicators of economic development i.e. the GDP per capita, productivity, human capital have a significant impact on Thus, the increase of the decentralization coefficient by $10 \%$ (the share of spending or tax 
revenue) results in an average GDP growth per capita of $0.3 \%$. While there were no significant differences in study results between unitary and federal States. The indicators of income decentralization usually provide more outstanding results than the indices of the expenditure decentralization.

The perception of decentralization, especially its financial component, as a means of effectively addressing interregional imbalances, alignment of levels of development of successful regions and rural areas is quite common in the economic theory and regional policy practice.

A deeper analysis by Rodríguez-Pose A. and Ezcurra R. (2011) of decentralization processes in terms of financial, political and administrative components on the example of OECD countries indicates their very contradictory effectiveness. The countries with a high income were analyzed, thus they were combined according to the similarity of the preconditions and factors of the economic growth. It is important that the authors of the study analyzed the fiscal decentralization in the close relationship with political and administrative measures, rightly stressing the priority of the latter in a significant number of the regional policy activities. The study included not only the income but also the expenditure aspects of the fiscal decentralization. Costs were investigated in the context of their functional components in order to determine the level of impact on the potential economic growth. It is alleged that in the group of countries that are investigated there are negative consequences of the fiscal decentralization for the economic growth prospects. These negative manifestations take place despite the functional purpose of the budget expenditures. Therefore, it can be argued that at a sufficiently high level of the socio-economic development of countries and regions fiscal decentralization loses its positive potential impact on the economic growth. The exception, according to this study, is less developed regions with a low level of the financial decentralization. In such cases, a moderate growth of fiscal decentralisation, in terms of stimulating current spending, contributes to the economic growth. Rodríguez-Pose A. and Ezcurra R. (2011) proved, "in the case of OECD countries, the potential economic benefits of fiscal decentralization in terms of economic performance are more than counterweighed by the potential economic pitfalls of transferring ever greater resources to subnational tiers of government".

In this context, it is important to determine the appropriate level of decentralization in Ukraine as a country with a developing economy. In the transition from a highly centralized economic policy and development characteristic for the post-planned economies in the process of decentralization political and administrative components become rather important. They contribute to the improvement of the territorial organization of the public administration, strengthening of the institutional, political and economic viability of a local government and improvement of the regional policy effectiveness. The assessment of the Ukrainian decentralization experience is largely determined by the financial performance. The growth of performance indices of local budgets for 2015-2018 shows both changes in a real socioeconomic condition of the territory and development opportunities. The growth in the financial resources available to local authorities helps more quickly and efficiently solves current problems of the economic development and finance projects aimed at supporting of a long-term growth. These include infrastructure projects, development of entrepreneurship and attraction of investment capital.

The concept of a local self-government reform and territorial organization of power, corresponding changes in the Budget and Tax codes of Ukraine, approved in 2014 include significant changes in the financial system. Thus, the principle of local budgets independence was broadened; the local budgets received more than 50 income sources and started stimulating fiscal capacity of communities; the system of fiscal equalization that provides horizontal 
alignment of the fiscal capacity of the territories depending on the level of the income tax on incomes of physical persons per inhabitant was changed; the promotion of territorial communities to unite and transit to direct inter-budgetary relations with the state budget for the appropriate resource provision as for the cities of regional importance, etc. was introduced.

The results of four years of reform implementation are already evident. Thus, the share of own revenues of local budgets (General Fund) in GDP rose from 5.1\% in 2014 to 6.5\% in 2017 (and $7.1 \%$ is the forecast for 2018); the volume of own revenues of local budgets increased over the 2014-2017 period with 68.6 billion UAH. to 192.7 billion UAH.; the share of local budgets (with transfers) in the consolidated budget of the country increased from $45.6 \%$ to $51.2 \%$; the share of local taxes and duties in own revenues of local budgets (General Fund) increases from $0.7 \%$ to $27.3 \%$ (2018 - 30.0\%), according to "Monitoring of the decentralisation process and local government reform" (2018).

In Ukraine and its regions the financial performance of enterprises are improved. Thus, as of 2017 the number of enterprises (excluding banks and budget institutions) per 10 thousand of the existing population exceeded the medium Ukrainian level (80) in the industrial Dnipropetrovsk, Zaporizhzhya, Kyiv, Mykolaiv, Odesa, Kharkiv regions. The regions are specified taking into account the development of small and medium enterprises and are powerful engines of the economic growth. A gradual increase in the number of enterprises, showing the net profit from activities, must be considered to be another positive tendency. In the period from 2010 to 2017 in Ukraine the percentage of profitable enterprises increased by more than 15 percentage points from $57.3 \%$ of the total number of enterprises to $72.5 \%$. The highest growth rates tend to be in the group of medium-sized enterprises, a common trend for all regions of Ukraine (Fig. 2.4).

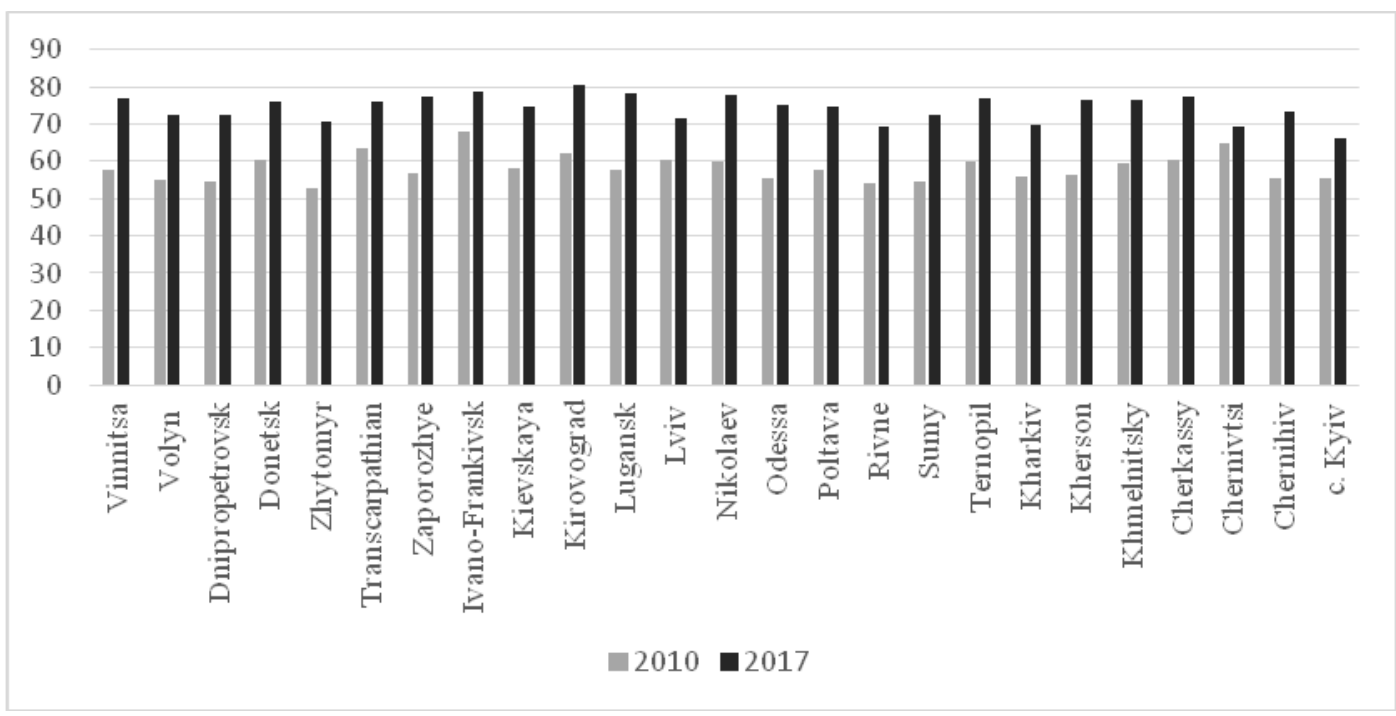

Figure 2.4. Businesses that made a profit in \% to the total number of enterprises* Source: compiled by the author based on the Regional statistics data, av. at http://www.ukrstat.gov.ua

* The data are presented excluding the temporarily occupied territory of the Autonomous Republic of Crimea, Sevastopol and the temporarily occupied part of the territories in Donetsk and Lugansk regions 
The performance of the decentralization reform creates its positive perception among the population. Thus, according to sociological studies (Decentralization and local government reform. Analytical report, 2017),79\% of people in the country know about the local government reform and decentralization, $58 \%$ support it. There are considerable changes in people's attitudes to the reform before and after the unification in a territorial community. $62 \%$ of residents of the villages, that were not united, support the reform only in the case that their village becomes the center of a new community. After the unification the reform support remains at the level of 60-62 \% even in the villages that do not become centers for new communities. It is significant that the inhabitants of the cities that had hardly supported the idea of unification (in $201563 \%$ opposed) changed their attitude. In 2017 about 50\% are in favour of the creation of a unified with the neighbouring villages community. The support for reforms among the population is gradually increasing together with the productivity growth which also stimulates their further course.

A balanced socio-economic development of regions is the key to the macroeconomic growth in the long term. For Ukraine and its regions the problem of interregional imbalances is relevant throughout a long time. In the period of 2005-2016 interregional changes in the economic development take place. In most regions of the country the share of a gross regional product per capita from the national average figure has grown. However, most regions are below the overall average. With the exception of Dnipropetrovsk, Kharkiv, Kiev, Poltava, Zaporizhka regions. The national average GRP per capita in Kyiv remains too high in comparison with the average of the country (Fig. 2.5). It is the decentralization reform aims to reformat the financial, administrative relations in the vertical "centre-regions" to strengthen the capacity of the latter.

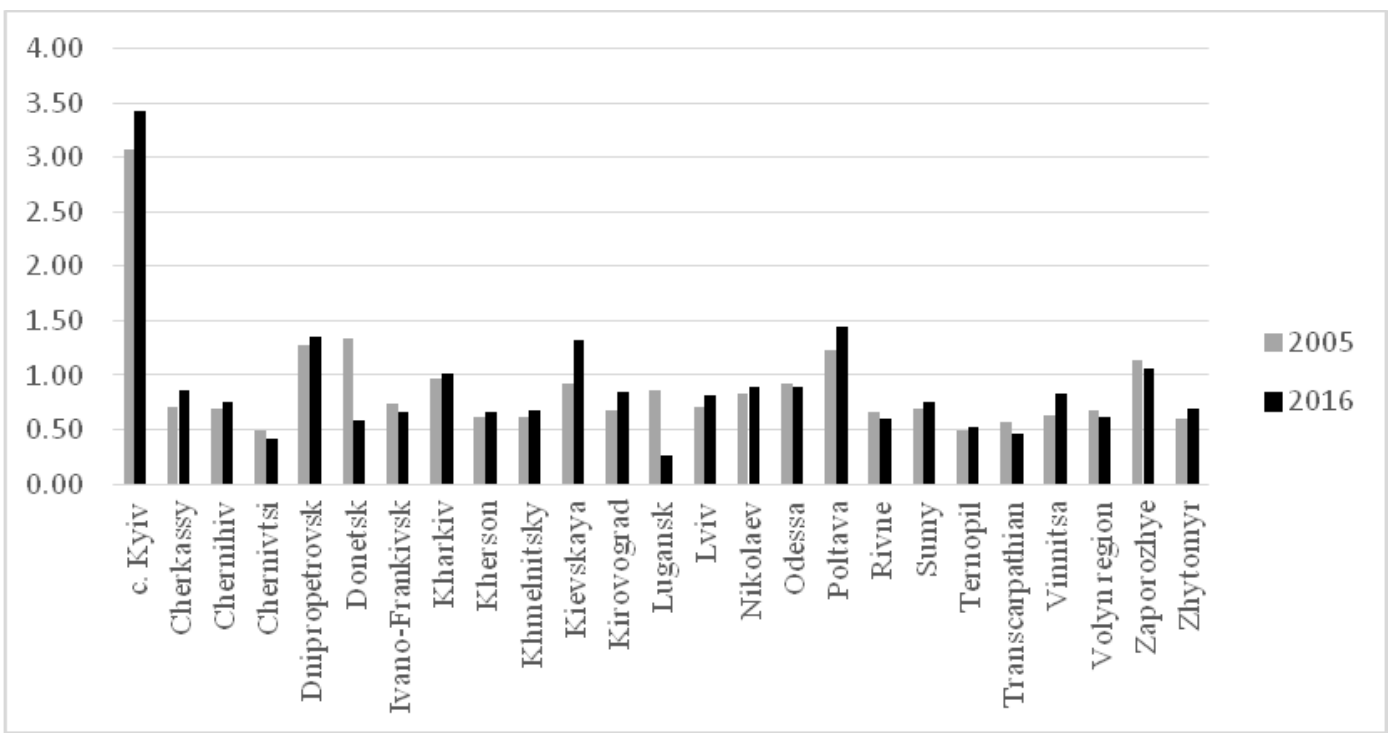

Figure 2.5. The level of a gross regional product in reference to the average in Ukraine* Source: compiled by the author based on the Regional statistics data, av. at http://www.ukrstat.gov.ua

* The data are presented excluding the temporarily occupied territory of the Autonomous Republic of Crimea, Sevastopol and the temporarily occupied part of the territories in Donetsk and Lugansk regions 
The European experience confirms the decentralization effectiveness at the stage of the country's balanced spatial economic system formation. The experience of regional policy in the EU countries can be useful in case of its application in Ukraine according to the following priorities. Firstly, the definition of key long-term strategic development objectives of the country and the region, that brings together industry, sector and purely spatial priorities that are relevant as "growth centers". Secondly, the introduction and development of transparent and non-corrupt mechanisms in the state and regional government practice, which ensures a more efficient allocation of development resources, makes basis for the sustained economic growth. Thirdly, a continuous institutional improvement through the development of formal and informal institutions, the combination of a co-financing and partnership between the state, business and local communities can increase and enhance the effect of the application and implementation of property rights.

The spatial aspects of the economic development of countries largely determine the model of the political system, the structure and efficiency of the economic system, the strategy of the State economic policy. Reduction of the spatial differentiation, convergence appears to approach the levels of a socio-economic development of the regions, which is a necessary condition for maintaining the integrity of the national economy and long-term strategy of its growth. Decentralization reform provides a qualitative change of the territorial organisation of the management of the economic development of the country. Its success requires a high level of responsibility of the local authorities in the new conditions and advanced features, activating the participation of local communities in the formulation, implementation and monitoring of local development, increased the State information policy of decentralization issues.

\section{References}

Financial decentralization: results and perspectives Available at:http://decentralization.gov.ual Decentralization support was confirmed by sociology Available at: http://www.minregion.gov.ual

Allen-Dupre D. Decentralization and socio-economic development at the level of regions and communities Available at: http://otg.cn.ua/wpcontent/uploads/2018/03/2018_01_03_report_1Report_Decentralization_Wave3_UKR.pdf

Subnational Government Structure and Finance Available at: https://stats.oecd.org/Index.aspx?DataSetCode $=S N G F$

http://otg.cn.ua/wpcontent/uploads/2018/03/2018_01_03_report_1Report_Decentralization_Wave3_UKR.pdf Rodríguez-Pose, A., Krøijer, (2009). A. Fiscal Decentralization and Economic Growth in Central and Eastern Europe. LEQS Paper No. 12/2009 October 2009 Available at: http://www.lse.ac.uk/europeanInstitute/LEQS\%20Discussion\%20Paper\%20Series/leqspaper12. pdf.

Rodríguez-Pose, A., Ezcurra, R. (2011). Is fiscal decentralization harmful for economic growth? Evidence from the OECD countries, Journal of Economic Geography. 11, 619-643. Available at: http://otg.cn.ua/wpcontent/uploads/2018/03/2018_01_03_report_1Report_Decentralization_Wave3_UKR.pdf Financial decentralization in Ukraine. The first stage of success Available at: http://www.minregion.gov.ual

Monitoring of the decentralisation process and local government reform. Available at:http://otg.cn.ua/wpcontent/uploads/2018/03/2018_01_03_report_1Report_Decentralization_Wave3_UKR.pdf Regional statistics.Available at: http://www.ukrstat.gov.ual 
Decentralization and local government reform. Analytical report by 2017 Available at: http://otg.cn.ua/wp-

content/uploads/2018/03/2018_01_03_report_1Report_Decentralization_Wave3_UKR.pdf

\title{
2.3. POLICY OF SOCIO-ECONOMIC DEVELOPMENT OF UKRAINIAN REGIONS UNDER THE CONDITIONS OF DECENTRALIZATION
}

\author{
Volodimir Kulishov \\ Doctor of Pedagogical Sciencies, PhD (Economics), Honored Educator of Ukraine, \\ Professor of the Polonia University in Czestochowa, Poland, \\ Professor of the International Economics Department, \\ Kryvyi Rih Economic Institute of Kyiv National Economic University \\ named after Vadym Hetman, Kryvyi Rih, Ukraine \\ Andrzej Krynski \\ Professor, PhD, Polonia University in Czestochowa, Czestochowa, Poland \\ Vitaliy Vedeneieiv \\ PhD (Political Science), Associate Professor of the International Economics Department, \\ Kryvyi Rih Economic Institute of Kyiv National Economic University \\ named after Vadym Hetman, Kryvyi Rih, Ukraine \\ Yevgeniy Shatalov \\ Assistant of the International Economics Department, \\ Kryvyi Rih Economic Institute of Kyiv National Economic University \\ named after Vadym Hetman, Kryvyi Rih, Ukraine
}

Under conditions of modern market relations the importance of the issue of the development of the economy of certain economic regions is currently growing. For a long time the regional aspects of economic relations have been ignored, although they play a key role in socio-economic transformations. This is confirmed by the officially adopted course on decentralization policy, which can solve many issues of political, legal, organizational, financial, resource and methodological nature, i.e. the formation and functioning of a new paradigm of relations within the region. In these circumstances, the policy of decentralization should be aimed at creating conditions for improving the regions competitiveness as the basis for the dynamic development of the state. In this regard, it is necessary to reorient the region's economy to the innovative model of development. The main strategic resources and the main drivers of economic growth in the regions are structural changes, processes, reforms and human potential, in which the regions are fully capable of regulating existing potential, which will ultimately make it possible to maximize the contribution to the national economy, to ensure the enhancement of competitive advantages at the regional, national and world markets.

Today the reform of Ukrainian regions status should be based on the positive experience of developed European countries and the implementation of European standards of decentralization, taking into account their own the regions national features of functioning, which help avoid many mistakes, reduce material costs and time, and optimize region's individual algorithm for implementing reforms.

It is necessary to draw attention to the fact that processes taking place in each of the world countries as a whole, and in Ukraine, in particular, are influenced by global trends. 
According to economist I. Misliaeva (2008), one of such tendencies is a factor of globalization, which alters the ability of the state to influence the process of regulation of national economic systems in the context of expanding the scope of transnational corporations within national economies.

It is common knowledge that new contacts emerge and large political unions are formed as a result of globalization. Besides, a number of state functions are handed over to the international level under the control of supranational structures. The development of Western European and Pacific regions is likely to create even more powerful centers of political, socio-cultural and economic gravity for Ukraine in the future and will eventually influence the policy of our state significantly and cause certain administrative-territorial consequences.

On the other hand, there is a local tendency in Ukraine, which is promoting the socalled corporatization of regional government structures. It is a common knowledge, that there are national and multinational corporations in many cities of the country which determine the political and socio-economic development of the region essentially. Over time, such business structures and organizations usually gain state-governing functions and shadow impact of businessmen on elected bodies of power or state administrations representatives can be easily transformed into organic structures that govern separate regions. A clear distribution into political and economic power for which citizenship is not important is more likely to take place later. Such innovations have started in Ukraine since 2014. The legislation was amended, and the expatriate leaders became typical for the top management of Ukrainian civil service dealing with economy and economic activity. Actually, as Vedeneev V.O. (2017) mentioned, even if political power structures continue to be formed by election or pseudoelection, competitive selection process is most likely to prevail in economy and administration top management, which can ideally ensure the efficiency of economic management.

It should be borne in mind that under the above mentioned external and internal political conditions, economic relations within the regions represent the most dynamic and at the same time weakly regulated processes. The penetration of commodity-money relations in all spheres of society requires a mechanism that can influence the ties and dependencies that arise at the regional level, and above all, in individual consumer markets.

According to many experts (Dotsyuk L., 2014; Galchinsky A., 2009; at al.), decentralization should be carried out after the introduction of amendments to the legislation of the administrative-territorial system, which depends mostly on the rights and opportunities of territorial communities to address regional government. Consequently, decentralization, according to the definition of a modern terminological dictionary, is a "managerial political system designed to make important practical decsions that are geographically or organizationally beyond the direct influence of the central government; a political process involving the delegation of certain powers by the central government to the local level in order to optimize the practical solution of issues of national importance, as well as the implementation of specific local regional programs" (Kulishov V.V., 2008), that is, building a new model of state power in Ukraine.

Problems of the territorial structure of the state in various aspects have been represented in the scientific works of many domestic and foreign researchers, but they are still remaining a priority issue regarding the change and functioning of the regional structure of the state today.

The study of the problems of the regional economy (for decentralization) requires, first of all, reviewing the essence of the concepts of "region" and "regional market". Traditionally, the 
region was considered to be a certain territory, which is a component of the national economic complex of the whole country, and in fact the specific relations between economic entities within the region itself were completely ignored. Therefore, in resolving the theoretical problems concerning the foundations of a comprehensive comparative analysis of socioeconomic development of regions and their interaction in conditions of market relations, the regional market, in our opinion, should be regarded as a form of territorial organization in the sphere of production, circulation, distribution and consumption. Therefore, one of the main tasks of the authors' research is considered to be representing of the essence of the region as a unit of socio-economic environment, since it allows formulating initial provisions and concepts that can be widely used in the future in theoretical studies and practice of economic development of separate territories and state in general (Kulishov V. V., 2002).

When determining the economic essence of the region and the regional market let us name the starting points:

- a region is a certain territory with its specific climatic, economic, geographical, demographic, historical, ethnic, social and strategic features. The boundaries of the region do not always coincide with the boundaries of administrative-territorial formations, and sometimes they are generally vague, "blurred" (Sonko S.P., 2000);

- development of the economy of the region depends not only on macroeconomic system, legal and regulatory framework, scientifically grounded local production, but also on those factors and laws that define the uniqueness of the area (at least in purely geographical terms) (Kulishov V.V., 2008);

- the exclusiveness of the economic sector of the region is determined by the prevailing technical and economic peculiarities of industrial and even political lobbying, the social atmosphere, that is, by everything that gives grounds to allocate regional cycles of reproduction;

- subjects of regional economic relations are natural and legal persons (residents) whose economic, social, political, cultural and ethnic interests have a high degree of spatial localization, is associated with the manifestation of economic activity in various forms within a given territory (Galchinsky A., 2009);

- for most regional economic entities (including households, small entities, etc.) interaction in the regional market, in fact, is the only possible and favorable form of realization set of economic and other relationships and interests.

The above provisions are based on the consideration that the concept of "regional market" has both economic and spatial components. It causes the necessity to combine two fundamental market definitions which exist in economic theory. The first determines the market as a mechanism of interaction among agents and has its own laws, factors, principles, etc. The second defines the market as a meeting place for economic subjects (economic agents). We consider one of the main features of the regional market to be a significant limitation of output opportunities, forms, methods and trends of the presentation of any subjects economic activity. If we consider certain quantitative and qualitative characteristics of the material or intangible object in economic interpretation to be limited to purely economic interests, the problem of limited resources and products can be traced so brightly and vividly at some areas that it suggests considering them critical ones in shaping behavior of participants in economic relations.

Several aspects of limitations should be marked out at the regional level,. First of all, it concerns the spatial, territorial, and plane limitation that affects the choice of local mineral resources, water, forest, land and other natural resources. This aspect has an impact, mainly in the mining industry, agriculture, material and water-based industries. Equally important is the 
economic and geographical situation, which determines (although to a large extent, subjectively) the specifics of interregional economic relations, the participation of the region in intergovernmental trade, and so on. Structural limitations are determined, first of all, by the peculiarities of the organization of production in certain territory, the specific processes of production at the companies, which are "centers of gravity" (according to M. Weber, "spots with a large agglomeration effect") for the region's economy, internal regional balance of production and consumption, features of the regional budget formation and distribution of central budget funds.

The brightest example of the limitations is the factorial potential of the region. At the same time, taking into account the purely geographical (according to etymology) definition of the region, this potential is predetermined by a specific set of climatic, demographic, economic, historical, ethnic, social, and other conditions (Vasilenko V.N., 2012). Continuing to disclose the complex of factors, we should dwell upon the fact that some of them are unchanged and when involved in economic activity become natural resources. Consequently, when using certain resources in the process of production of material or spiritual goods, the transformation of their qualitative and quantitative characteristics takes place.

As Myslyayeva I.N. (2008) mentioned, mineral resources, natural soil fertility, water content of the territory and some other natural components and their complex in any region can be treated as relatively unchanged. The same conditions that arise in the socio-biological area, that is, depend on certain features and results of the development of society, including economic sphere, can hardly be considered unchanged. So, the population (its general presence within the region) is determined by many factors and is not a constant issue. Social processes also affect mobility, variability and other characteristics (for example, ethnic, cultural and household characteristics of the population of the region).

We are in full agreement with Bilorus O.G. (2001) that there is no doubt as for variability of technological conditions, which affect the trends of the development of productive forces and industrial relations. The direction of such changes is determined by a set of socio-economic, political, socio-biological, psychological and other prerequisites, some of which directly or indirectly depend on the state of the economy. A set of all these conditions determines the specifics of economic relations within each region. At the same time, these relations themselves are also a variable condition. A complex of socio-economic conditions, which provide an opportunity to meet diverse needs, develops dynamically within every region. An important component of this complex is the factor potential of the region, on which the effectiveness of the functioning of the regional economic complex depends to a large extent.

The set of factors used by economic entities operating within the region often differs from its factor potential, which means that not each of the total set of factors available in the region is used in economic activity. It is determined not only by the specifics of the factors themselves, but also by the degree of technology development, the peculiarities of the economic and social structure in the region. Sometimes there are quite paradoxical situations when the self-regulated market economy is under open pressure from the state (that is, an example of the so-called political factor). For example, southern US states have large oil and gas deposits, but the use of these reserves is limited by the federal government, since most of the energy resources are legally classified as state contingent reserves, but previously, when these local resources were developed freely, the region had accumulated significant professional experience in the field of oil and gas production and processing, which became the prerequisite for the formation of powerful centers of the chemical industry, using natural raw material from other regions. 
Factor potential plays significant role in the process of changing the specialization of the economy of individual regions. The change of specialization may be caused by various reasons such as the depletion of mineral raw materials, the need for structural adjustment of the country's economy, market conditions, etc. However, the direction of such a change should take into account the existence of certain factors, preventing the increase of social tensions, negative impact on some industries or other regions. Such a trend, for example, can be traced in the iron ore basin of Kryvbas and the coal region of the Donbas.

Considering the factors of spatial mobility, their tendency to time and space changes, it is important to take into account the factor provision of the regions. Many factors (such as human resources, knowledge, funds) can change their localization quite easily and become factors in other regions. Therefore, the problem of such use of existing factors within the region is of particular interest, which would include their alternative presence in other regions, related to the creation of appropriate conditions of management in a certain area. At the same time, the internal nature of some factors ensures their generation and use in those regions where they were absent for some time. Thus, new know-how ant secrets of innovative production make one company (region) more competitive than others until the latter receive the same or even more advanced technology. This can take place in two fundamentally different ways such as legal or illegal receipt of someone else's technology (someone else's technology is considered to be a mobile factor) or the creation of their own unique technology. Thus, determining the essence of the regional market, it is necessary to consider the influence of limited factors on the formation of spatial complex of economic objects and the effectiveness of socio-economic processes and phenomena.

Socio-economic processes under conditions of regionalization and decentralization are of particular importance when designing a set of reforms, making adjustments to their implementation in the course of analysis and evaluation of the region and determining of the effectiveness of the organizational and economic system. To evaluate the effectiveness of regional development, Ukrainian expert Mykolaychuk M.M. (2009) suggest using ratings oriented to characterizing the territory economic and social indicators, or traditional methods of assessing the effectiveness, which are adapted to the regional economic subsystem. For example, O. Agafonenko (2007) expresses the opinion that the competitiveness of the regions is determined by the effectiveness of local self-government bodies and should be carried out on the basis of methods taking into account the peculiarities of the formation of competitive advantages at the regional level. V. Artemenko (2007) proposed to assess the achievements of regions regarding self-sufficiency and sustainability of development on the basis of five components that give broad description of the "quality of life" of the population. P. Matvienko (2008) offers another set of indicators for a general assessment of the socioeconomic status of the regions. It includes the gross regional product, investment in fixed assets, banks' claims on loans, income levels, average salaries and wages, level of registered unemployment, etc.

It is obvious, there is still a lack of unity among the experts on the complex of the indicators that characterize the competitiveness of the region, and lack of understanding on set of parameters to be assessed by such indicators, so the issue of assessing the region's efficiency in conditions of decentralization should be at the center of state research. At the same time, while there are hot discussions about the problem of the determining key indicators characterizing the region competitiveness within the expert environment, the Ministry of Regional Development, Construction and Housing and Communal Services of Ukraine monitors the following indicators of the process of regionalization dynamics within the framework of the program "Monitoring the process of decentralization of power and reforming local self- 
government" (the data from May 10, 2018 are represented at the table 2.4). This data indicate an increase of $1.4 \%$ of the share of local budget revenues in GDP from 2014 to 2017. This situation is due to more effective use of resources on the ground, which in turn stimulates the increase of own income and increases the general level of well-being.

Table 2.4. Dynamic of Indicator 6.1 for the period 2014-2018 years

\begin{tabular}{|l|c|c|c|c|}
\hline Year & $\begin{array}{c}\text { share of local } \\
\text { budget } \\
\text { revenues } \\
\text { (general fund) } \\
\text { in GDP, } \%\end{array}$ & $\begin{array}{c}\text { own revenues } \\
\text { of local } \\
\text { budgets, UAH } \\
\text { billions }\end{array}$ & $\begin{array}{c}\text { share of local } \\
\text { budgets (with } \\
\text { transfers) in the } \\
\text { consolidated budget } \\
\text { of Ukraine, } \%\end{array}$ & $\begin{array}{c}\text { share of local taxes } \\
\text { and fees in local } \\
\text { government } \\
\text { revenues } \\
\text { (general fund), \% }\end{array}$ \\
\hline 2014 & 5,1 & 68,6 & & 0,7 \\
\hline 2015 & 5,1 & 98,2 & 45,6 & 26,6 \\
\hline 2016 & 6,2 & 146,6 & 47,5 & 28,8 \\
\hline 2017 & 6,5 & 192,7 & 51,2 & 30 \\
\hline $\begin{array}{l}2018 \mathrm{MFU} \\
\text { forecast }\end{array}$ & 7,1 & 231 & 51,5 & 27,3 \\
\hline
\end{tabular}

Source:compiled and calculated by authors according to the "Monitoring of the process of decentralization of power and reformation of local self-government", 2018

The represented above data indicate that in the period from 2014 to 2017, the local budget revenues of Ukraine grew by 124 billion UAH. In 2018, the upward trend is also maintained. The total amount of financial resources available to local governments in 2017 exceeded half of the consolidated budget of Ukraine for the first time and amounted to 51,2\%. The data, represented at the table 2.4 indicate an increase in the share of local taxes and duties by $26,6 \%$ for the period from 2014 to 2017 . This situation is explained by the fact that due to the unification of separate territorial units a new fund of accumulation of tax funds was created, as well as new sources of tax receipts were created.

Table 2.5.shows an increase of almost 3.1 billion UAH in the amount of allocated funds for the implementation of projects at the local level. This state of affairs is due to the fact that the state is interested in developing potential projects that will improve the existing infrastructure and pursue new opportunities for the regions.

Table 2.5. Indicator 7.5: state financial support through the State Fund for Regional Development

\begin{tabular}{|c|c|c|}
\hline Year & $\begin{array}{l}\text { Funds (billion } \\
\text { UAH) }\end{array}$ & Projects(units) \\
\hline 2015 & 2,908 & 876 \\
\hline 2016 & 3 & 810 \\
\hline 2017 & 3.5 & 803 \\
\hline 2018 & 6 & 0 \\
\hline
\end{tabular}

Source:compiled and calculated by authors according to the "Monitoring of the process of decentralization of power and reformation of local self-government", 2018

Apparently, the above statistics indicate an increase in the financial potential of Ukrainian regions only indirectly, in particular, the growth of local budget funds for the period from 2014 to 2018, which generally reflects the increase of financial capacity of the regions due to the state decentralization policy. 
Taking into account all the above said, we believe that regional market under conditions of decentralization can be comprehended as stable relations between economic entities and their aggregations whose interests are realized within a certain territory, and elements of economic behavior are required by parameters of factors characteristic to the place of their economic activity. Such understanding of the regional market provides an opportunity to consider the problems of economic development of individual regions in a fundamentally new way of the perspective. Thus, when the regional market is often treated as a set of highly localized socioeconomic processes and relations in the sphere of product circulation formed by the influence of demand and supply in each administrative-territorial entity, it limits the subjective composition of economic relations in the region significantly and immediately, unduly narrowing the set phenomena and processes under the influence of which the regional economy is formed (it means limiting the economic processes in the region only to the sphere of circulation).

However, as you know, a developed regional market can function effectively, first and foremost, in the presence of industrial and agricultural production, consumer services with the volume of commodity products (services) sufficient to participate in the formation of intra-and inter-district balances of consumption of goods and services. It, certainly, does not mean that the industry and agriculture of the region can fully meet their needs for products of a certain range, but their share in the creation of the market should be significant. In this case, the predominance of locally produced goods should be based not on "local patriotism", but on economic expediency. At the same time, considering the problem of functioning of market relations in the region, it would be a mistake to focus on the development of goods and services markets only.

At the same time, it should be borne in mind that each region creates its own conditions for the market functioning. The factors that determine the specificity of regional production processes include the resource and production potential, the features of investment and logistics, the degree of legal protection of territorial entities, the nature of lobbying regional interests by higher authorities, the specificity and structure of property relations, the internal fiscal policy, the peculiarities of the territorial structure and organization of production, the level of development of market infrastructure and the possibility of conducting foreign trade operations.

Therefore, the mechanism for the functioning of regional markets under the conditions of decentralization should be based on the fact that a region is a part of the national economic space, in which complete cycles of reproduction of the population and labor resources, fixed and circulating assets, part of national wealth, money circulation, production, distribution, exchange and consumption of products, as well as the interaction of cooperating companies and associations with local governments bodies take place.

It is impossible to elucidate fully the actual issues of reforming the administrativeterritorial system, decentralization and regional governing in Ukraine in one article. However, our analysis of recent research on scientific approaches gives grounds for certain conclusions.

Firstly, along with the traditional factors of product placement, which continue to dominate in the "old" areas of specialization, the new, purely market ones are gaining in importance. First of all, they include the globalized market situation, which specifies the process of spatial relations and provides a clearer territorial definition of the concept of "region" under the conditions of territorial-administrative reform. Secondly, the solution of most socioeconomic problems associated with raising the standard of living of a population is possible only under the condition of effective structure of the administrative-territorial unit, the application of a more sophisticated methodology for assessing the impact of regulatory acts of local authorities on the appropriate use of public funds in the region and index of human potential development in the region. Thirdly, in our opinion, the formation and implementation of "social capital" at both the national and regional levels is important in the context of 
decentralization, and guarantees trust of society in power, reforms, economy, investments, innovations.

To sum up, the modern policy in the area of the regional (territorial) economy is to change, and it is, first and foremost, the structural process, the search for new people with entrepreneurial talent and the ideas of reducing pressure on business, innovative content, investment interest, in the first place, on the part of the state, and strengthening the regulatory and controlling function of decentralization. We believe that the main objective of the national decentralization policy should be to find an optimal balance between involving the country in globalization processes and supporting the national-specific forms of management and elements of socio-economic processes at the regional level.

\section{References}

Agaphonenko, O.Yu. (2007). On the Need for a System of Indicators of Regions Competitiveness.Regional Economics. No. 1, 51-62.

Artemenko, V. B. (2007). Indicators of Sustainable Socio-Economic Development of the Regions.Regional Economics. No. 5, 90-97.

Bilorus, O. G. (2001). Globalization and the national strategy of Ukraine.Prosvita.

Vasilenko, V. N.(2012). Diagnostics of the development of regions: types, approaches, techniques: monography. Donetsk: OOO South-East Ltd.

Vedeneev, V. O. (2017). Application of the principle of holism to the modern vision of the essence of the state. Politics: Sciences. Journal.Issue. No. 1, 52-56.

Galchinsky, A.(2009). Methodology of analysis of economic globalization: logic of renewal. Economy of Ukraine. No. 1., 4-18.

Dotsyuk, L. (2014). Administrative-territorial arithmetic (instead of 11500 communities there should be no more than 1500). Uriadovy Courier. No. 83, 7.

Kulishov, V. V., Sonko, S. P., Mustafin, V. I. (2002). Market and regional studies: Textbook. K.: Nika-Center.

Kulishov, V. V. (2008). Micro-macroeconomics. Lviv: Magnolia-2006.

Kulishov, V. V., Picha V. M., at al. (2014). Political science: modern terms and concepts. A short instructional vocabulary for students of higher educational institutions. Lviv: New World-2000.

Matvienko, P. (2008).Main criteria and models for assessing the effectiveness of public administration.Economy and the state. No. 6, 70-76.

Mykolaychuk, M. M. (2009). Economic policy of regional development in the conditions of globalization: monography. Kyiv.: K.I.S.

Myslyayeva, I. N. (2008).The role of the state in the regulation of national economic systems.Bulletin of the Moscow University. Series 21: Management (state and society). No. 4, 13-21.

Pavlenko, I. G., Humenna, O. V., Matukova, G. I. (2012). Features of development of regions of Ukraine in new economic conditions: monography. Simferopol: DIAPI.

National Decentralization Project.Monitoring of the process of decentralization of power and reformation of local self-government as on May 10, 2018.Ministry of Regional Development, Construction and Housing and Communal Services of Ukraine.Available at: http://decentralization.gov.ua/uploads/library/file/260/Monitoring_10.05.2018.pdf

Sonko, S. P. (2000). Environmental issues from the standpoint of chorology. Ukraine and global processes: geographic dimension. Kyiv-Lutsk. 


\title{
2.4. DECENTRALIZATION REFORM IN UKRAINE: REGULATORY AND ORGANIZATIONAL ASPECTS
}

\author{
Olena Berezina \\ PhD (Economics), Professor, \\ Professorof the Finance Department, \\ Cherkasy State Technological University, Cherkasy, Ukraine
}

At the present stage of system modernization of Ukraine a real basis of good management is to ensure a stable and balanced development of territories through decentralized reforms and implementation of a new regional policy. The main objectives of these processes is creation of conditions for management and civic initiatives at the local level; giving local communities greater freedom in the sphere of economic choice; the introduction of efficient instruments and mechanisms to stimulate entrepreneurship, local economic initiatives and sustainable local development.

According to the current legislation, decentralization of power is a transfer of significant powers, resources and responsibilities from executive authorities to local governments. This policy includes provisions of the European Charter of a local self-government and the best international standards of public relations in this sphere.

Local government reform in Ukraine includes: the system of strategic planning, financial decentralization, monitoring and evaluation (competitiveness of regions, their socio-economic integration and management effectiveness) and institutional support of regional development.

However, the complexity of decentralized reforms is requires to observe the principles of consistency, comprehensiveness, integrity and consideration of all aspects of the reform process, as each of the components plays an important role in the implementation of the strategic objectives of the new state regional policy.

Gavkalova N. (2014) mentioned, that imbalances in the development of regions point to the need for a differentiated approach to the implementation of decentralization reform and stimulation of the development of certain territories.

The main areas of decentralization and transformation of the relationship between central and local governments are as follows:

- $\quad$ providing access of local authorities to financial markets and credit resources;

- establishing new criteria for the administrative responsibility of heads of local authorities and managers of budgetary funds;

- the introduction of new principles and mechanisms of relations "power - public" about the formation of the programs, mechanisms of accountability and public control;

- change in cash collateral regional programs in accordance with changes in functions to ensure proper development of the social sphere of regions and the provision of social services of an adequate quality.

System shocks undergone by the regions of Ukraine form new requirements for sustainable local development, specific problems of individual communities, promoting interregional cooperation and cooperation, etc. In turn, this requires a harmonization of objectives, priorities, tasks and activities of the central and local bodies of the Executive power, bodies of local self-government for solving of both current problems of regional development and achieving long-term strategic goals.

Given the strategic choice of European integration, decentralization reform should meet the European norms and standards. This approach will involve new (approved by the international practice) organizational and institutional mechanisms and instruments of regional 
policy implementation; to diversify sources, to introduce new approaches to the provision of budget funds and the financing of development areas; to empower the administrative-territorial units with respect to attracting private capital funds, international funds (including structural fund grants by the European Union) for financing regional and interregional projects.

Therefore, based on the characteristics of the Ukrainian economy and taking into account the objectives of this reform, the decentralization mechanism should have the following features:

- $\quad$ agility and adaptability, availability of an internal self-regulating system which would be triggered by the deviation from the chosen strategy, would neutralize the negative inertial force and give the opportunity to move to the planned development path to implement the chosen strategy.

- a high degree of scientific reliability and certainty in regional and local socioeconomic development;

- $\quad$ the interest consistency of various actors of the regional policy;

- reliability.

The legislative framework for fundamental changes in the government system and its territorial framework at all levels began to take shape in 2014.

In April 2014 the government approved the basic concept paper - the Concept of reforming local government and territorial organization of power. Afterwards the action Plan for its implementation, which gave a start to reform, was approved. To implement the provisions of the Concept and objectives of the action Plan it was necessary first to amend the Constitution of Ukraine as well as to form a package of new legislation.

Changes to the Constitution first and foremost were to solve the issue of executive bodies formation of regional and district councils, reorganization of local state administrations in the bodies of a control and supervisory type to give a clear definition of the administrative-territorial unit that is the community.

Currently the main package of new legislation has been done and is in action, the priority legislation initiatives are being implemented, namely:

1. Laws on amendments to the Budget and Tax codes of Ukraine. The fiscal decentralization took place due to these changes: local budgets in recent years rose by 123.4 billion UAH: from 68.6 billion UAH in 2014 to 192 billion UAH in 2017. The share of local budgets in the consolidated budget of Ukraine is constantly growing and at the end of 2017 amounted to $51.2 \%$ (in 2015 - 45,6\%).

2. The law "On voluntary association of territorial communities". provided the opportunity to build a capable base level of a local government. At the beginning of June 2018 743 consolidated territorial communities were established (CTC). These CTC included 3443 former local councils. Now more than 6.4 million people live in the CTC. International experts consider these rates of intermunicipal consolidation to be very high. The law also introduced the elder institution in the CTC, representing the interests of rural people in the communal council. Today 653 elders have already been elected, more than 1.8 thousand people perform the duties of the elders.

3. The law "On cooperation of territorial communities" created a mechanism to address common community problems: disposal and recycling of waste, development of a common infrastructure. At the beginning of June 2018 the 187 th cooperation agreement was impemented. This mechanism was applied by 810 communities.

4. The law "On fundamentals of state regional policy". State support of regional development and infrastructure of communities for reform grew by 39 times: from 0.5 billion in 2014 to 19.37 billion in 2018. 21 regions accepted the decision on creation of regional 
development Agency, in all areas Centers of development of local self-government, including helping local authorities to implement the regional strategy are in operation.

5. The law "On amendments to certain legislative acts of Ukraine on decentralization of powers in the sphere of architectural and construction control and improvements of urban development legislation". New urban development powers were granted to 99 cities, including 11 CTCs.

6. A package of laws to extend the powers of local governments and optimisation of administrative services. It enabled local authorities of the appropriate level to delegate powers of basic administrative services: registration of place of residence, issuance of passport documents, state registration of legal entities and individuals, entrepreneurs, associations of citizens, registration of acts of civil status, rights, land issues etc.

7. "The state strategy of regional development for the period till 2020" (2014), which is very close to the structure of such documents of the member countries of the European Union. There is a possibility to finance regional development at the expense of the State Fund for regional development (SFRD), which functions as a budgetary program of the State budget according to article 24-1 of the Budget code of Ukraine. Now all regions of Ukraine have elaborated the strategy of development until 2020 or 2025.

The new legislative framework significantly strengthened the motivation for intermunicipal consolidation in the country, created appropriate legal environment and mechanisms for the formation of capable territorial communities of villages, settlements, cities, which unite their efforts in solving pressing problems. Also a new model of financial provision for local budgets, which received a certain autonomy and independence from the Central budget, payed for itself.

The support for decentralization reform in Ukraine is one of the priority tasks that will contribute to the development of local self-government and economic development of the country as a whole. It is expected that 2018 will be the key year in making a basic level of local self-government: by the end of the year most of the existing small local councils can unite, thus become able to take on most of the powers, properly use resources and take responsibility for their actions or inactions to the people and government. This will create a stable foundation for the next steps of the reform of local self-government and will accelerate reforms in healthcare, education, social services, energy efficiency and other sectors.

As a result, fiscal decentralization, cities and united local communities (ULC) have received significant additional resources for their development.

Strategic planning of their development CTCs carry out on the basis of such projected financial resources:

- $\quad$ use of own revenues;

- $\quad$ use of SFRD funds for the development projects;

- $\quad$ use of funds of the state subventions for the development of the CTC infrastructure.

- $\quad$ the attraction of international technical assistance (ITA).

However it should be understood that all has to be provided with the relevant projects. The project must conform to the shape, which is determined by those who provide the funds for the project; have a clear purpose, identified problems; a reasonable budget; the possibility of the existence of the created object, the institutions after the completion of project financing from an external source.

SFRD funds should finance projects of a strategic nature but not current repairs. Therefore, the task of local authorities is to use SFRD primarily on projects that create infrastructure leading to the land capitalization, the value added formation, the growth in household incomes. 
To support the decentralization reform in Ukraine since 2007 the international community directed 15 projects and assistance programmes that will run until the 20202021 year (table. 2.6). The largest incoming financial flows planned in the framework of the EU "U-LEAD" - the total amount of 102 million Euro; the US project "DOBRE"- the total amount of 50 million USD; projects of the Council of Europe, the Swedish Empire, the Danish Kingdom of the Netherlands, Swiss Confederation, Finland, Canada and other countries - in total more than 30 million EUR.

Table 2.6. Programmes and projects of the international assistance to Ukraine in the implementation of the decentralization reform

\begin{tabular}{|l|l|l|l|}
\hline The name of the program / project & $\begin{array}{l}\text { The amount of the } \\
\text { benefit }\end{array}$ & Start date & $\begin{array}{l}\text { Completion } \\
\text { date }\end{array}$ \\
\hline Project DESPRO & 9.3 million CHF & 24.12 .2007 & 24.06 .2020 \\
\hline $\begin{array}{l}\text { The strengthening of local initiative in Ukraine } \\
\text { (MFSI-II) introduction }\end{array}$ & 4.7 million USD & 01.10 .2011 & 31.12 .2017 \\
\hline Gender budgeting in Ukraine & 46.6 million SEK & 12.11 .2013 & 31.12 .2018 \\
\hline $\begin{array}{l}\text { UNDP/EU "Local development, oriented on the } \\
\text { community" }\end{array}$ & 23.8 million EUR & 01.01 .2014 & 30.12 .2017 \\
\hline $\begin{array}{l}\text { Swedish-Ukrainian project "Support of } \\
\text { decentralization in Ukraine" }\end{array}$ & 31.8 million SEK & 08.09 .2014 & 31.12 .2018 \\
\hline $\begin{array}{l}\text { Local self-government and the rule of law in } \\
\text { Ukraine }\end{array}$ & 28.3 million SEK & 01.10 .2014 & 31.12 .2017 \\
\hline $\begin{array}{l}\text { Expert support of the governance and economic } \\
\text { development (EDGE) }\end{array}$ & 18.8 million CAD & 10.11 .2014 & 31.07 .2019 \\
\hline $\begin{array}{l}\text { The restoration of governance and } \\
\text { reconciliation in the territories affected by the } \\
\text { crisis }\end{array}$ & 3 million USD & 01.01 .2015 & 31.12 .2017 \\
\hline $\begin{array}{l}\text { The partnership for towns development } \\
\text { (PROMIS / PLEDDG) }\end{array}$ & 19.5 million CAD & 27.03 .2015 & 30.06 .2021 \\
\hline $\begin{array}{l}\text { E-governance for accountability of authorities } \\
\text { and community participation (EGAP) }\end{array}$ & 4.3 million CHF & 01.05 .2015 & 31.03 .2019 \\
\hline $\begin{array}{l}\text { The development of the local self-government } \\
\text { self-strengthening policy in Ukraine (PULSE) }\end{array}$ & 18.2 million USD & 14.12 .2015 & 13.12 .2020 \\
\hline The program U-LEAD & 102 million EUR & 01.01 .2016 & 30.06 .2020 \\
\hline A joint programme of UNDP and UN Women & 10 million EUR & 01.05 .2016 & 30.11 .2017 \\
\hline Program DOBRE & 50 million USD & 08.06 .2016 & 07.06 .2021 \\
\hline $\begin{array}{l}\text { Sustainable local development in rural areas of } \\
\text { Chernivtsi and Odessa regions }\end{array}$ & 500 thousand & 01.12 .2016 & 31.05 .2018 \\
\hline $\begin{array}{l}\text { Source.compiled and calculated by } \\
\text { Euthor }\end{array}$ & & retried \\
from
\end{tabular}

Source:compiled and calculated by author based on data retried from http://decentralization.gov.ua.

The experience and assistance of international partners in terms of decentralization helps Ukraine not only develop its territory, create a capable government but also promotes the country's integration into the European space. The experience of Poland is especially useful for Ukrainian reforms, where such changes also had to be held in difficult conditions of transition from the Soviet to the European system of governance. According to estimates, for example, the French experts, a project, which can be implemented in Ukraine, is the most ambitious and serious not only in Ukraine but also in Europe. For Ukraine it is important to analyze the 
practice of European countries, to apply the European Union a positive experience. Of course, Ukraine will not be able to use the concept of local government reform in France or Germany, but the Ukrainian strategy need to be implemented.

The basic idea of decentralization, as noted above, is the transfer of power from the center to communities that must change the mentality of communities and make them more proactive and entrepreneurial, which will lead to their cohesion and unity to address the most important issues. Practical but not theoretical government is the best tool for educating of active and concerned citizens. However, watching the reform of government in Ukraine, we can conclude that Ukrainians underestimate its importance and, in their opinion, this reform is not at the time, as Ukraine's hostilities continue. But the real war is the war for self-government, because it is a war for where in the future Ukraine will come and if it enters the circle of European culture. Peace in Ukraine largely depends on geopolitics, but the territorial selfgovernment depends on the Ukrainians themselves. Self-governing encourages people to a public dialogue. The real budgets of the communities, their large competencies encourage citizens to make conscious and responsible attitude to the election of local authorities and then its control.

Poland took a similar path but the poles overcame a centralized system much easier. This is true not only of powers and fiscal relations, in fact it is functions of ministries, which are partially transferred to the local level. We are not talking about creating separate territorial governments in each community. Functions and powers of the central authorities and ministries in all spheres and fields are transferred to the local self-government: from education, healthcare to architecture and construction control and land relations. All procedures and regulations, which under the Constitution belong to the powers of local authorities and which are under the authority of the government, President and Parliament, are clearly written out and voted in the first reading amendments to the Constitution and guarantee the ubiquity of local selfgovernment. Therefore, the district should possess only those powers which concern cooperation between the United territorial communities. The region should remain only those powers which relate to joint activities of communities, such as the maintenance of public facilities.

What is the necessary period of time for the completion of the unification process of communities? It is clear that no one can be forced to do something, also the name of the law "On voluntary Association of territorial communities" contains the word "voluntary". People must clearly understand what benefits and prospects the reform will provide. It's only a tool, the purpose of the reforms is the regional development. At the same time it should be noted that Ukraine undergoes reforms at an accelerated pace (Poland needed eight years, France 15-20 years). Now we need to show what changes in the life of United communities, what happens with the budget relations, development, social and transport infrastructure, the approximation of administrative services to the people. It would be right to say that the state budget must have a separate line on the allocation of funds to support the infrastructure and the provision of administrative services to the united communities. Such state support will encourage those who are thinking.

Thus, there is a simple principle: when people walk this path alone, through the understanding, all the processes happen very quickly. The task is to find arguments to show the advantages and assure that the Union was voluntary.

Today there is a lot of fraud around the principle of voluntariness put in the basis of the united community creation. No one can be united by force, we are talking about a voluntary association of communities. But if, say, two villages want to join or the district authorities want to unite all into one community - this must not be, because there is a method of forming self- 
sufficient territorial communities, approved by the corresponding Decree of the Cabinet of Ministers, there is also the law on local self-government bodies. Only taking into account the legislative framework and normative-legal acts a unified territorial community is formed. And after the adoption of the law on the administrative-territorial system in Ukraine the concept of cities of regional importance will disappear. All communities will have the same status, powers and equal rights.

Thus, after the reform of local self-government and territorial organization of power in Ukraine about 1.5 thousand United territorial communities will be formed, and on the territory of Ukraine 150 districts with completely different power levels will appear. New areas are integrated administrative units on the territory of which the prefects will operate. The main challenges that may hinder effective implementation of the principles of decentralization are the following:

- corruption;

- the usurpation of power by local influential "princelings";

- the incompetence of the local authorities in the performance of duties;

- resistance to the transfer of funding to local communities by the Central government;

- the reluctance of central authorities to delegate powers and "the destructive actions of populist politicians".

A real, according to the needs and interests of the association, community will form wealthy and self-sufficient territorial units, i.e. the community. These communities will be able to clearly identify their needs, set priorities and achieve them. United communities will have the same powers as the cities of regional importance, and will be able to change over to direct interbudgetary relations with the state budget of Ukraine. Thus, the single tax and tax on profits of enterprises remains entirely at the disposal of companies; local councils get the right to own land tax and will install it rate. However, local taxes and charges, fixed earlier, also remain in the budgets of local self-government. All the lands of the community, including those located outside of the settlement are transferred to the jurisdiction of each council. The government promises to local communities high authority, to leave at their disposal a maximum of fiscal revenues (taxes), while the community itself will define, where or why to use these tools. Under the legislation, communities will keep more than 60 percent of the tax to incomes of physical persons and $5 \%$ of excise duty, now transferred to the district, regional and state budgets.

Ukraine has accomplished much in the processes of decentralization. It is a hard work, the success of which largely depends on the newly formed communities. Professional managers at the local level must be prepared. A reasonable concept for financial control and areas budgeting must be developed. An important factor in the decentralization reform is the availability in the community of a strategic vision of development of their territories and support of these plans by the local population. This is extremely important for attracting investment to the regions.

Thus, the decentralization reform is demonstrating positive results. As of June 2018, 3443 territorial communities in Ukraine united in 743 CTC that is $31.4 \%$ of the total number of councils of the basic level as of 01.01.2015. The decentralization of power and financial authority of the state in favor of the local self-government is one of the most important reforms since the Ukrainian independence.

The main strategic objective of modernization of public management and territorial organization of power, which is exercised today, is the formation of effective local selfgovernment, creation of comfortable conditions for accommodation of citizens, providing them with high-quality and affordable public services. The achievement of these goals is impossible 
without an adequate level of economic development of the territories concerned, their financial security and sufficient sources of filling local budgets.

The financial aspect is one of the most important as the successful operation of the territorial communities largely depends on it. The presence of economically active business entities, a sufficient number of qualified human resources, developed industrial and social infrastructure is the basis for the successful development of companies.

The result of the reform was to promote the involvement of local authorities in increase of incomes in local budgets, search of reserves of their content, improvement of administration of taxes and fees. United communities show high and dynamic pace of growth of own incomes. In the use of funds the attention focuses on the necessity of forming the optimal structure of budget expenditures, the establishment of effective, not too numerous managerial staff, conducting the ongoing analysis of budget spending and in prevention of cases, of their irrational use.

Performance of local budgets reflects the general socio-economic situation in the relevant territory and its potential towards sustainable development. The availability of sufficient resources in local budgets is key to ensuring that the community is able to provide high quality and more diverse services to its residents, to implement social and infrastructure projects, to create conditions for development of entrepreneurship, raising investment capital, develop programs for local development and to finance other activities to improve the living conditions of the residents of the community. For example, the share of own revenues of local budgets in GDP rose from $5.1 \%$ in 2014 to $7.1 \%$ in 2018(Fig. 2.6), and the volume of own incomes of local budgets -68.6 billion UAH in 2014 to 231 billion UAH - that is 3.35 times(Fig. 2.7).

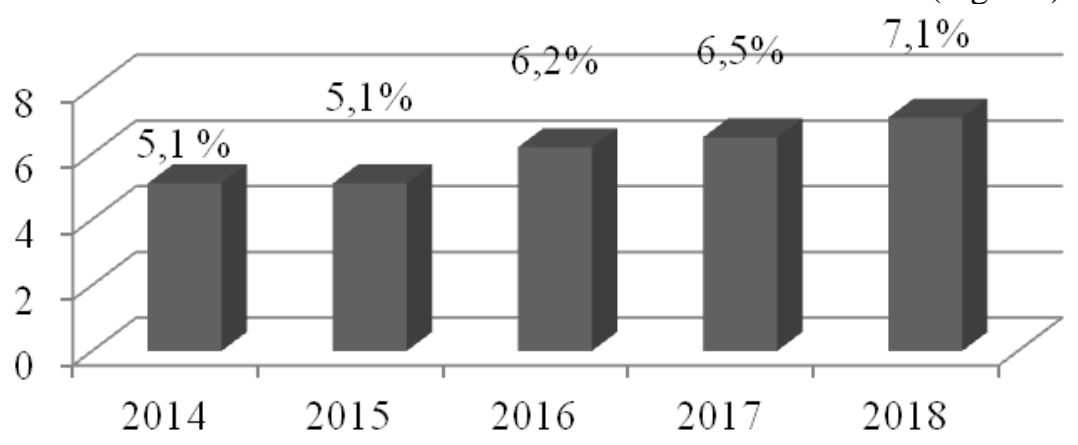

Figure 2.6. The percentage of own revenues of local budgets(consolidated fund) in GDP in 2014-2018*

Source:compiled and calculated by author based on data retried from http://decentralization.gov.ua

*2018 - Forecastby Ministry of Finance of Ukraine

Revenues of local budgets of Ukraine for the first half of 2018 grew by $23.8 \%$ or by 20.7 billion compared with the same period of 2017. Thus, the total amount of own incomes amounted to 107.7 billion UAH. Local governments have the tax to incomes of physical persons - UAH 63.3 billion UAH which is more from the revenue in January-June of the previous year by UAH 13.6 billion UAH (+27.3 per cent), payment for the land -12.6 billion UAH $(+2,3 \%)$, single tax $-\mathrm{UAH} 13.2$ billion $(+28.4$ per cent). 


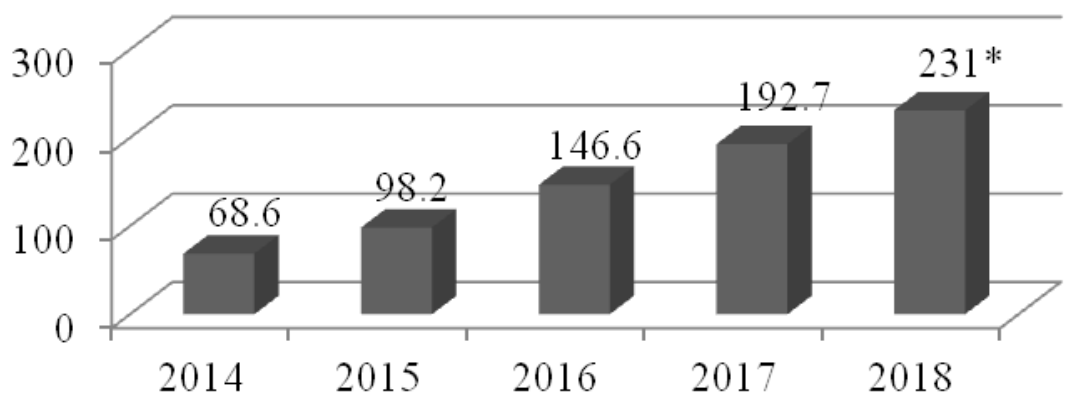

Figure 2.7. The dynamics of own revenues of local budgets in 2014-2018

Source: compiled and calculated by author based on data retried from http://decentralization.gov.ua

*Forecast by Ministry of Finance of Ukraine

The growth of local budgets compared to the same period last year occurred in all regions of Ukraine: from 223.2 million UAH in the Chernivtsi region, to 1.6 billion in Kharkiv. The budget of Kiev has increased by 3.3 billion UAH. The highest revenue growth over the previous year was recorded in Poltava $(+29,9 \%)$, Donetsk $(+28,0 \%)$, Ternopil $(+26,9 \%)$ regions.Revenues from personal income tax, the highest rate of growth recorded in Vinnytsia $(+31,1 \%)$, Khmelnytskyi (+30\%), Zhytomyr $(29,7 \%)$.Revenues from payment for the land are the best results in Sumy $(+13.3 \%)$, and Ternopil $(+13,3 \%)$, Lugansk $(+12,7 \%)$. As of June 01, 2018 fund balances of the general fund of local budgets on the Treasury's accounts amounted to 40.9 billion, on Deposit accounts -9.7 billion UAH.

According to sociological research, the expectations of Ukrainians from the local government reform are in a practical way. So, the majorities of Ukrainians believe that the government should fulfill their promises and transfer to local communities a high authority, to leave at their disposal a maximum of fiscal revenues. The survey showed that the majority of Ukraine's population (59\%) consider it necessary for the local government to reform the local self-government and decentralization. $42 \%$ of Ukrainians expect improvement of the situation in Ukraine after the reform. In addition, $43 \%$ of respondents believe that the decentralization reform will help to solve the military conflict in the East of the country. Hence, the people of Ukraine have clearly demonstrated their choice in favor of the European democratic development and decentralization of power. Therefore, the task of government is to provide citizens with the right to self-government and democracy participation in this process.

The population also expects the reforms to improve the efficiency of local government. These results of the survey are in the framework of the project "Monitoring of perception of reforms" organized by the company "TNS Ukraine" commissioned by the National Council of reforms. More than $40 \%$ of respondents indicated that decentralization provides for the transfer of the budget from the central government to local authorities. More than a third of respondents identified decentralization as an increase in the powers and budget of the regional government, while $29 \%$ are aware of the fact that we are talking about the formation of unified territorial communities.

With regard to the further development of the legislative framework, the adoption of such important laws is expected: 
- "On service in local governments" (new version). Ensure equal access to service in bodies of local self-government, increase the prestige of service in OMS, motivated local officials to assist in the community development as well as their own development.

- "On the principles of administrative-territorial structure of Ukraine" (the bill is ready for consideration in the Verkhovna Rada). The Constitution defines the basis for the administrativeterritorial system of Ukraine, types of settlements, the system of administrative-territorial units, powers of bodies of state power and bodies of local self-government on the issues of administrative-territorial structure, order of formation, liquidation, establishment and change of borders adminservice and settlements, maintenance of the State register of administrativeterritorial units and settlements of Ukraine.

- Land administration within the territory of the unified territorial communities. It will introduce the principle of ubiquity of the jurisdiction of CTC in land relations and provide the authority to dispose of lands outside settlements.

- Expanding the types of urban planning documentation at the local level. Eliminate current shortcomings in the regulation of urban planning will prevent the misuse and distribution of land.

- On the state supervision over the legality of decisions of bodies of local selfgovernment.

- "Urban agglomeration". Determines organizational and legal bases of formation of urban agglomerations territorial communities of villages, towns and cities, including the unified territorial communities, the principles and mechanisms of interaction of territorial communities within urban agglomerations, as well as forms of state support for urban agglomerations.

The success of reforms in the first stage indicate that Ukraine has chosen the right path and we need to move forward. We cannot stop any more. But the next step would be the modification of the Constitution regarding the decentralization, which is necessary for further promotion of the reform and its completion. Thus, decentralization is the key reform, which reloads the relations between central authorities and local self-government, the citizen and the government.

A new model of regional policy (the mechanism of state management of regional development) presupposes an optimal combination of independence of the territories, primarily in the sphere of the solution of daily questions of local development and coordinating and stimulating the of a center as a representative of the interests of the society and the country as a whole. The synergy of these two components forms the basis for a successful reform of public administration and local self-government, giving more powers and resources to the local communities, which are the basis of sustainable local development.

\section{References}

Gavkalova, N. L. (2012). Socio-economic development of the regions of Ukraine: problems and perspectives. Bulletin of the Precarpathian University.Economics. No. 9, 41-44.

Law of Ukraine "About the principles of state regional policy" Available at: http://zakon5.rada.gov.ua/laws/show/156-19.

Law of Ukraine "About the voluntary association of territorial communities". Available at: http://zakon5.rada.gov.ua/laws/show/157-19.

Resolution of the Cabinet of Ministers of Ukraine" About the approval of the state strategy for regional development for the period up to 2020" No. 385 dated 06.08.14. Available at: http://zakon0.rada.gov.ua/laws/show/385-2014-\%DO\%BF. 
Bila, S.O. (2014) Reforming public administration in regional development: state, problems, prospects (analytical report) Available at: http://www.niss.gov.ua/content/articles/files/Bila_ref7d611.pdf.

Savitsky, Yu. (2015) "This war is a war for self-government" - a Polish expert on Ukraine and the experience of Poland. Available at: http://www.radiosvoboda.org/content/article/27375301.html. Decentralization: official site. Available at: http://decentralization.gov.ua.

\title{
2.5. INTERIM RESULTS AND CONSEQUENCES OF DECENTRALIZATION REFORM: THE REGIONAL EXPERIENCE
}

\author{
YuliiaTkachenko \\ PhD (Economics), Associate Professor, \\ Associate Professorof the Finance Department, \\ Cherkasy State Technological University, Cherkasy, Ukraine \\ Yanina Kovalchuk \\ PhD (Economics), Associate Professorof the Economics and Enterpreneurship Department, \\ Cherkasy State Technological University, Cherkasy, Ukraine
}

A fundamental change in the global consciousness of Ukrainian citizens, clearly demonstrated by the Revolution of Dignity in 2014, a radical reorientation to the European democratic values, geopolitical changes in the country have emphasized the need to change approaches to spatial development on the basis of increasing the powers of territorial communities and with a focus on strengthening of their autonomy and responsibility for sustainable development of the area.

The development of local self-government and decentralization of power in Ukraine are the main priorities of socio-economic development. In April 1, 2014 the Government of Ukraine adopted the "Concept of local self-government reform and territorial power organization”, the decree of the Cabinet of Ministers №333-R. According to this Concept, Ukraine had to transfer both the authority and resources from local government bodies to rural and urban councils and create wealthy territorial communities, able to exercise their powers. In fact, the Concept deals with the need of real reforms of local self-government in Ukraine.

With the background formed, the decentralization has become urgent, therefore there are sufficient opportunities to implement European experience and reforms in Ukraine, but there are doubts about the institutional capacity of public and local authorities to implement this experience. The interim results of the reform and its prerequisites need an appropriate scientific and analytical justification, which will give the opportunity to evaluate the chosen course, the deviations, their causes and consequences.

The study of the decentralization reform implementation in Ukraine, specific features of spatial management development have become topical due to the decentralization reform implementation. However, spatial development, administrative-territorial reforms, public administration system in Ukraine, which has been in a state of "the permanent reform" for more than 15 years, was investigated by many foreign and domestic scientists such as V. Heyets, V. Bakumenko, Z. Varnali, Y. Volkova, R. Melnikov, P. Nadolishni, O. Popov, M. Porter, I. Fashchevski, T. Hershberg, L. Chernyk, et al. In the context of administrative reform as a complex socio-administrative problem the research done by I. Adamets is worth considering. The issue of social responsibility as the basis for the success of decentralization 
reform is investigated by O. Berezina (2011), global principles of territorial consolidation in the context of the global partnership are studied in the works of L. Petkova (2016) management of strategic development of the consolidated territorial communities is discussed in the studies of S. Seregina (2009), Y. Sharova (2012), E. Borodina (2015), N. Goncharuk (2012). In particular, the conceptual foundations of local self-government reform and power decentralization in Ukraine are studied, the current status and problems are analyzed, the European experience is summarized. Evaluation of decentralization reform in Ukraine is emphasized by A. Melnychuk, P. Ostapenko (2016).

Scientists devoted much of their research to the theoretical bases of decentralization reform implementation, in particular, the justification of conceptual provisions. Scholars and analysts conducted statistical observations on the quantitative results of the reform, namely the dynamics of the number of amalgamated communities, data about the size of the budget and finance statistics. There are also surveys on the understanding of the reform by the population and its consequences. However, there are no comprehensive studies on the evaluation of the decentralization reform efficiency not only by the means of quantitative parameters, but also by means of qualitative ones, in particular the objective assessment of the situation in the territorial communities of the local population, efficiency of the measures taken in the context of solving local problems etc.

The aim of the study is a comprehensive assessment of the interim results of decentralization reform in the context of problem-oriented focus. The objective of the study is to investigate the basic preconditions and the necessity of the decentralization reform implementation, the study of previous expectations, analytical conclusions and their evaluation in the aspect of problem orientation.

Melnichuk, A., Ostapenko, P. (2016) mentioned, that the reform of the administrativeterritorial structure of our country, launched together with the local government reform (decentralization reform). Ukraine is actively reforming the system of administrativeterritorial structure by creating united local communities.

The aim of the reform of the local government is primarily to ensure its ability by its own resources, to solve local issues. It means empowering of territorial communities with greater resources and the mobilization of their internal reserves.

Administrative reform in Ukraine is made according to three stages of implementation. Reformers note that the reform is based on the Scandinavian model of the ATG system. The first stage involves the transfer of the state powers to the lowest administrative-territorial level to the newly created united territorial communities (UTC), organized through the consolidation of rural councils. Most of the powers that previously belonged to district state administrations (DSA) will be transferred to the newly created UTC, thus proving the inefficiency of the DSA. In fact, united local communities are created through the reorganization of village councils and regions elimination according to the results of the first stage.

The second stage of the reform involves the creation of administrative-territorial units of the regional level that is prefectures (counties or districts), empowered with management authorities.

The third stage of the reform involves the formation of a third regional level of the ATU of the country. After the formation of the two lower levels of the ATU - local and subregional reform, it would be logical to complete the reform of the ATU higher system-level that is regional.

In fact, it would mean a reduction in the number of regions of the country. However, the reform of this ATU system-level at the expert one is little said, as long as there is no 
single option for the reform. The knowledge and methods of communal geography can be of great importance in this situation, as the domestic social geography has long had its own division variant of the country and socio-geographical areas, which should form the basis of a new regional division.

The necessity and urgency of the decentralization reform in Ukraine is due to several reasons, among which the most important are:

1) the excessive fragmentation of territorial communities (there used to be rural communities with the population range from 1000 to 300 persons (45.4\% of the total) in Ukraine before the reform), also there is a significant proportion of communities with the population of 500 to 1,000 residents $(35.8 \%)$. Territorial communities, the population of which not exceeding 500 people constitute almost $11 \%$ of the total number. Overall, $92 \%$ of rural territorial communities had a population of less than 3,000 inhabitants before the reform started.

2) subsidies from local budgets (more than 5000 territorial communities have a share of subsidization of the budget from 70 to $90 \%$, about 500 communities are maintained at the expense of the state budget).

3) significant financial resources are allocated to the maintenance of the administrative apparatus, limiting the ability of projects to solve problems of local importance.

4) degradation of rural territories (the population decline, the mass move of young people in the city, lack of infrastructure and facilities to ensure improvement and appropriate quality of life. As of January 1, 2017, the proportion of rural residents accounted for $28.7 \%$ of the total resident population (for comparison: in 1990 it constituted $32.7 \%$ ).

5) lack of initiatives on the part of local authorities and prolongate dependency on the Soviet management ideology.

From June 9th to $13^{\text {th }}, 2017$ the Fund "Democratic initiatives" named after Ilko Kucheriv jointly with the sociological service of Razumkov Centre conducted a nationwide exit pole (2018 respondents, aged 18 years, theoretical sampling error does not exceed 2.3\%)in all regions of Ukraine except Crimea and occupied territories of Donetsk and Lugansk regions. In August 2016 Fund "Democratic initiatives" and the Kiev international Institute of sociology had a similar study. As evidenced by the results of a survey for 2017, the level of awareness of citizens with the reform of decentralization improved somewhat: $20 \%$ of Ukrainians are well aware of the reform (in August 2016, the figure was 12\%), 62\% of respondents know something (54\% is the figure of 2016). The percentage of those who does not know anything about the reform, decreased from $30 \%$ to $18 \%$.

Ukrainians residing in the central regions of Ukraine (the level of awareness is more than $87 \%$ ) have the best awareness and the least is in the south of Ukraine $(69 \%)$. The majority of Ukrainians approve the actions of the authorities in the framework of decentralization reform, $42 \%$ of respondents have positive attitude. Most supporters of decentralization reform are in the West $(48 \%)$ and the least is in the East $(31 \%)$. On the other hand, only $12 \%$ of Ukrainians are fully satisfied with the pace of reform, $37 \%$ consider it to be implemented too slowly, and $22 \%$ suppose it not to be implemented at all.

The majority of Ukrainians sees both positive and negative consequences of decentralization reform, in particular $24 \%$ of respondents noted a new influence on the government, $18 \%$ believe in the improvement of the quality of services. $28 \%$ of respondents believe the reform negative effects to deepen the "society stratification", $16 \%$-to devastatevillages and towns.

The financial and analysis materials prepared by the Ministry of Regional Development, construction and housing and communal services of Ukraine with the 
assistance of the Swiss-Ukrainian project "Decentralization Support in Ukraine" DESPRO, ULEAD Europe: Programme for Ukraine with empowerment at the local level, accountability and development and the Swedish-Ukrainian project "Decentralization Support in Ukraine", show the General Fund of Local budgets of territorial communities United for 2016 increased almost 7 times, compared to the income of 2015 in their local councils, which became a part of the GSS, and amounted to 7.1 billion UAH, including for the account:

- taxes and fees - 3.3 bln UAH, of which $60 \%$ of the tax to incomes of physical persons amounted to 1.7 bln $\mathrm{UAH}$;

- intergovernmental transfers in the form of basic subsidies, educational and medical subventions - 2.8 bln UAH;

- subventions to the communities infrastructure formation -1 bln. UAH;

In addition, the communities received a subvention from the state budget for socioeconomic development of territories in the amount of $50 \mathrm{mln}$ UAH and funds in the sum of $134 \mathrm{mln}$. UAH from the State Regional Development Fund for implementation of investment programs.

Based on 1 inhabitant of the united communities, the average ratio of own revenues grew by 1645 UAH (from 700 UAH to 2345 UAH). Slobozhanskaya UTC of Dnipropetrovsk region received maximum funds per 1 inhabitant -16 thousand $\mathrm{UAH}$.

According to the outcomes of the sociological surveys results systematization organized by various expert agencies, it was determined that among the main problems / obstacles in the implementation of the decentralization reform, the respondents distinguish: financial imbalances; inadequate legal framework; lack of clear division of powers between district administration, district councils and UTC; the need to comply with the declared data; lack of awareness of decentralization; the lack of agreement within communities; political processes. However, more than $70 \%$ of respondents support the reform and believe in its successful implementation.

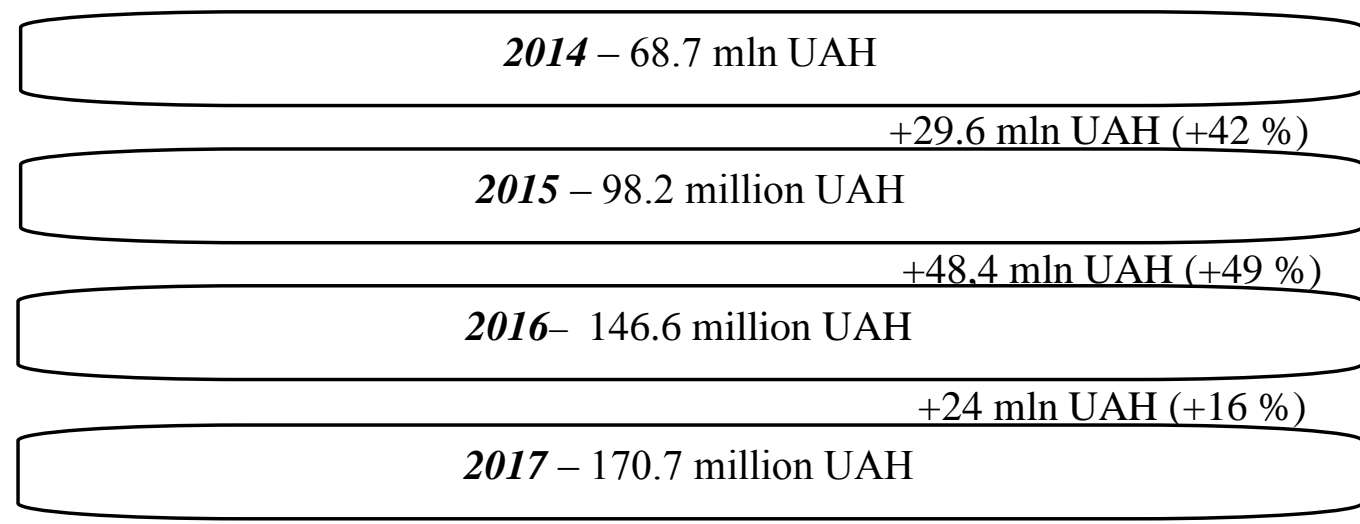

\section{Figure 2.8. Growth in own resources of local budgets}

Source: compiled and calculated by authors based on data retried from http://decentralization.gov.ua

Experts suppose that the decentralization reform must be sped up, the consolidation of the communities in the UTC must be implemented on the principles of economic efficiency, provide a more democratic approach of regional governments in the creation of the UTC. 
Table 2.7.Interim results of the decentralization reform

\begin{tabular}{|c|c|}
\hline $\begin{array}{l}\text { The reason / need for } \\
\text { decentralization reform }\end{array}$ & Interim results of the decentralization reform \\
\hline $\begin{array}{l}\text { The excessive } \\
\text { fragmentation of } \\
\text { territorial communities }\end{array}$ & In 2015-2016 Ukraine created 366 consolidated territorial communities. \\
\hline $\begin{array}{l}\text { Subsidized local } \\
\text { budgets }\end{array}$ & $\begin{array}{l}\text { All UTC changed over to direct inter-budget relations with the State } \\
\text { budget, received financial sources, own authorities at the level of the } \\
\text { regional cities. }\end{array}$ \\
\hline $\begin{array}{l}\text { A significant part of } \\
\text { financial resources is } \\
\text { allocated for } \\
\text { administration funding }\end{array}$ & $\begin{array}{l}\text { There were about } 12 \text { thousand units of self-government before the } \\
\text { reform, and after the reform there should be } 2-2.5 \text { thousand. Downsizing } \\
\text { of the management stuff naturally leads to a reduction of maintenance } \\
\text { costs }\end{array}$ \\
\hline $\begin{array}{l}\text { Degradation of rural } \\
\text { areas }\end{array}$ & $\begin{array}{l}\text { Financial resources obtained as a result of decentralization reform in } \\
2016 \text { helped communities to: } \\
\text { - implement spending powers in the socio-cultural sphere, namely, to } \\
\text { finance secondary education institutions and kindergartens for a total } \\
\text { amount of } 2.5 \text { billion UAH; to organize the provision of primary } \\
\text { medical care to community residents and to fund secondary medicine } \\
\text { services - } 0.9 \text { billion UAH; to provide for the maintenance and } \\
\text { organization of the community centers, libraries, sports institutions, to } \\
\text { provide social assistance to the population - } 0.5 \text { billion UAH; } \\
\text { - to finance the executive offices of local authorities - } 0.5 \text { billion UAH; } \\
\text { - implement infrastructure projects and local programs and activities - } \\
1.9 \text { billion UAH, including repair of roads, accomplishment of territories } \\
\text { and projects in housing and communal services - } 1.1 \text { billion UAH, } \\
\text { repair and reconstruction of institutions of the socio-cultural sphere - } 0.6 \\
\text { billion UAH; } \\
\text { - to provide administrative services, to establish community centers and } \\
\text { to carry out other expenses related to their powers. } \\
\text { It should be noted that the largest part of financial resources of the } \\
\text { community was directed on the realization of powers in the socio- } \\
\text { cultural sphere - } 60-70 \% \text {, the implementation of infrastructure objects } \\
\text { and investment projects - } 25-30 \% \text {. It proves that during the first year of } \\
\text { operation in the new status the united communities could spend the third } \\
\text { part of their funds for the development of their territories. }\end{array}$ \\
\hline $\begin{array}{l}\text { The lack of initiatives } \\
\text { on the part of local } \\
\text { authorities }\end{array}$ & $\begin{array}{l}\text { Decentralization reform provides for the voluntary association of } \\
\text { territorial communities on the principles of initiative, vicarious liability } \\
\text { and partnership. }\end{array}$ \\
\hline
\end{tabular}

Source:compiled by the authors based on http://decentralization.gov.ua/news/item/id/5244.

Thus, the main purpose of the decentralization reform is the creation and maintenance of a favorable living environment, necessary for full human development, providing residents of territorial communities with qualitative and accessible administrative and social services through sustainable development of viable communities. The reform gives the opportunity for consolidation of communities, the development of civil society.

The efforts aimed at the decentralization of financial resources are an important part of the local government reform. Positive results in this regard are proven by the indicators of 
local budgets use, increasing of the share of local budgets in the consolidated budget of Ukraine and indicators of financial decentralization.

It became possible due to the interest of local governments to expand revenues to local budgets, search of reserves of their content and efficiency administration increase of taxes and fees.

Regarding the use of funds by local governments, including the united territorial communities, the emphasis shifted from the consumer position (the expectation of subsidies from district and provincial budgets), to attempts to create an effective administrative apparatus and to direct resources to the communities development, to carry out analysis of budget spending and to prevent cases of inefficient or irrational use.

\section{References}

Law of Ukraine "About the approval of the Concept of local government reformation and territorial organization of power in Ukraine". Available at: http://zakon3.rada.gov.ua/laws/show/333-2014-\%D1\%80.

Melnichuk, A., Ostapenko, P. (2016) Decentralization of power: reform number one. Kyiv: OP "Globus".

Decentralization. Local budgets of 159 consolidated territorial communities Available at: http://www.minregion.gov.ua/wp-content/uploads/2017/04/De-centr_297x210_April-2017.pdf Public opinion about the decentralization reform Available at: http://dif.org.ua/article/gromadska-dumka-naselennya-shchodo-reformi-detsentralizatsii.

Financial decentralization and the budgets of the first 159 united communities in details Available at: http://decentralization.gov.ua/news/item/id/5244. 


\title{
CHAPTER 3
}

\section{SOCIAL AND HUMANITARIAN CONTENT OF THE GLOBAL PARTNERSHIP FOR LOCAL SUSTAINABLE DEVELOPMENT}

\subsection{MASS-CONSUMPTION SOCIETY IN THE CONTEXT OF SUSTAINABLE DEVELOPMENT}

\author{
Angela Boyko \\ Doctor of PhilosophySciencies, Professor, \\ Head of the Philosophy and Political Sciences Department, \\ Cherkasy State Technological University, Cherkasy, Ukraine \\ Oleg Grygor \\ PhD (State Management), Associate Professor, \\ Rector ofCherkasy State Technological University, Cherkasy, Ukraine
}

The society of mass consumption is the meaningful marker of a modern society that is beyond any questions. The reason for this consensus is because the society of mass consumption has many structural components providing it with such a status. We are talking about global interaction, development megatrends of mass culture, the media and, of course, the human masses, which are not only a quintessence of the other structural components of a society of a mass consumption, but also acquires the characteristics of a motivating phenomena and processes factor based on a mass effect.

The socio-philosophical analysis of consumption wants to discuss, at least, five paradigmatic approaches: economic (B. Avtonomov, G. Becker, J. Keynes, J. Clark, D. Ricardo, A. Smith), marketing (F. Kotler, K. Pearson, N. Pringle, M. Thompson), sociology (R. Aron, P. Bourdieu, V. Ilyin, J. Humans), psychological (Z. Freud, P. Lunt) and cultural (G. Bart, M. Godel, G. Simmel). The theoretical background may serve as a philosophical position in relation to the analysis of the problems of consumption (J. Baudrillard, F. Jameson. B. Porshnev, A. Ujomov, et all).

The literature analysis proves that the study of consumption mainly takes place in two directions. Firstly, they involve disclosure of private types, for example, conspicuous consumption (Th. Veblen, Yu. Zimerman); addictive consumption (J. Baudrillard, V. Ilyin), ascetic consumption or consumption of specific product groups. Secondly, these studies are focused on the analysis of the consumer society.

The development of scientific ideas about the consumption is due to the needs of social practice, the emergence of new forms of social organization that is a society of consumption. The phenomena of a mass consumption society are analysed in the works by $\mathrm{S}$. Bauman (2006), D. Bell, J. Baudrillard (2001, 2006, 2007), G. Debor (2000), V. Zolotukhin (2001), V. Inozemtsev (2005).

It is important in theoretical and methodological terms to take into account the achievements of scientists on the problems of anticonsumerism (G. Marcuse, E. Potter, N. Klein), advertising and branding (G. Armstrong, B. Lebrun, F. Kotler, L. Percy, G. Roster), institutionalism (J. Buchanan, A. Williamson, J. Searle, J. Hodgson) as well as the formation and functioning of the consumerism ideology (S. Moscovici, G. Harry).

The historical evolutions of consumption and consumer forms are reflected in the writings of F. Braudel, T. Veblen, A. Gurevich, E. Durkheim, M. McLuhan et all. 
A philosophical approach to consumer practices, illustrated by the Bodriard's concept shows the essence of consumer goods as philosophy or hedonism representatives, joy, pleasure, happiness simulacras.

In 1931 the work of Karl Jaspers, "The Spiritual Situation of Time" was published which analyzed the characteristic features of societies in the twentieth century. Jaspers thought that a person's life from the beginning to the mid-twentieth century is the existence in the bounds (terms) of the crowd, tyrannical adherence to conventional values, normativism and standards. Life on the principle of "I like all» shares the burden of individual responsibility with the other members of the crowd or gets rid of this painful existential duty. Technological progress, excessive pragmatism and total rationalization of life played a trick on him. Distinguishing himself from the tradition and the principle of likeness to God, a man found himself in the form of machines and mechanisms, which were to serve him. He became only a function of the huge mechanism of the human mass. The person identity was substituted by the "efficiency", and the consciousness and responsibility was substituted by the faceless Samiatinskya "we".

J. Baudrillard introduced the world view of a modern society in the form of a black hole that sucks in all the meanings, signs, methods of analysis, offering instead a reality simulation. This huge mass has neither object no subject. Its desire is consumption without any meaning and usefulness. Now the society gets pleasure not from the sense but from its neutralisation. According to the J. Baudrillard, the end of XX - beginning of XXI century is the era of hyperreality with the reality phantoms, simulacra and when even such obvious realities as the mass and the crowd, acquire fantastic signs, there are phenomena with the prefix quasi-, under-.

S. Bauman (2006) explains causality of an unprecedented rise in the consumer world as follows: "the desire of the individual to assert himself was ousted from the sphere of material production. But the unusually wide scope for this desire opened at the new "pioneer frontier" - in the boundless world of consumption, which is dynamically developing. It seems that in this world the capitalism finally discovered the secret of the philosopher's stone: from the point of view of consumers in the consumer world (unlike the sphere of production and distribution of wealth and power) free from the curse of the fight against exclusion and monopolistic functions. Here the struggle goes on and without any shootout and the number may not only decrease but grow. A remarkable freedom from the world of consumer selfdestructive tendencies of all other forms of competition have been achieved through the transfer of interpersonal rivalry in the field of wealth and power (that is, the benefits, the proposal which by their very nature limited and therefore will be subject to the unbridled monopolization) in the symbols sphere".

The ideology of consumerism includes the following substantive provisions: 1) consumption is an endless process; 2) consumption is the only possible form of manifestation of absolute freedom; 3) consumption is the only possible process of social cognition, socialization, and stratification; 4) consumption is directly involved in the production (consumption as "negative production" and at the same time a resource for the production of goods); 5) consumption is an exclusive mechanism for the individualization of a man and his development; 6) satisfaction from consumption is a moral backbone of the modern man.

A. Bard and J. Zoderkvist (2004) talk about the emergence of a new type of mass information or consumtariat. In their view, it is the mass of people whose main activity is the consumption. They do not create new values for the society and nature. They are passive 
participants in the consumption chain. "Consumtariat is a lower class due to a lack of social intelligence, the rules set out in the information society".

Consumtariat manipulates the information elite, which the authors call netocracy. According to A. Bart and J. Zoderkvist (2004), netocracy or netocrat is the ruling class of the modern world: "the new ruling class is inherently cosmopolitan. A netocratic globalization leads to the emergence of a global electronic culture. Netocrats are characterized by the fact that they manipulate information rather than manage a property or produce the goods". . Fedchenko S. (2015) noted that one of the problems that we face in the context of the analysis of modern mass properties is "a way of articulating the interests of the masses. Today, everyone can express the point of view via social networks, forums, blogs, portals, etc. It is possible to ascertain a wide diversity of opinions, however, there is a reverse side to this manypoints of view - the person begins to get lost in the flow of contradictory information, so that it is often difficult to determine their own position and the information elite uses it. It is very easy to impose the favorable group-specific picture of reality on the confused man. Thus there is a very important problem of the possible identity of the masses and their interests".

The authors of "Netocrat" (A. Bard, J. Zoderkvist, 2004)claim that "today there are grounds to argue about a different form of the mass except consumtariat. We call it "selective consumer", which evolved to another stage of development. As Fedchenko S. (2015) noted, he starts selectively, critically perceive information coming from the outside. He purposefully looks for the information he needs, often rejecting the imposed one from outside. If 7-10 years ago an intrusive Internet advertising worked well, now the user is rarely interested in paying attention to these blocks. However, the methods of manipulation have changed, become more sophisticated. Therefore, the mass remains unchanged despite its qualitative change".

In Jerusalem has long been accepted to pay for adviced to two reasons: firstly, the advice is a service and every service should be paid for, secondly, the benefits obtained as a result of unpaid tips, was considered to be a theft. The society of mass consumption is trying to create the illusion, they say, for the first time in the history a man is not obliged to pay for the comfort of life and in our time, a flow of media declares that all is paid and is all inclusive. In fact, each of us a priori pays a particular price, depending on the degree of involvement in the vortex of consumption, advertising perception and media "hints".

Expressive assessment of this phenomenon was given by Gi Debord (2000) in "Society of the spectacle": "the consciousness of the viewer is drawn into the vortex of a false attitude, and now he neither sees life as the pursuit of self-realization nor as a desire for death. Those who have already abandoned the consumption of their own lives, are unable to admit even the possibility of their death. The life insurance ads inspire confidence in a person that she/he will be to blame herself/himself for his /herdeath, if not in advance to ensure the proper functioning of the system after such "irreparable economic losses." Advertising The American Way of Death, in turn, insists that the system is able to provide such conditions of existence. On all fronts of the advertising attack to grow old is strictly forbidden. However, even if all and each had invented a "youth elixir", it could be used only indirectly, it wouldn't be sustainable for the accumulation like financial capital. Beyond our attention is the fact that the social absence of death is equivalent to the lack of social life".

In the intellectual environment of modernity a kind of comme Il faut, a common courtesy rule is a ruthless critique of market relations, blaming them for all deadly sins - from degradattiof the human consciousness to the erosion of social and cultural foundations of a society. Unfortunately, the prevalence of this approach does not provide it with the argumentation perfection. O'Connor J. (2006) noted that significant drawback of validity is at least the fact that the free market described by Adam Smith, existed for only about 150 years 
- from 1750 to 1900 . He made possible an unprecedented increase in productivity and, in fact, gave rise to the society in which we live now.

However, in the twentieth century the free market has largely degenerated into a degrading economic mechanism. One can distinguish at least three genealogically caused reasons of the free market destruction: firstly, it significantly deforms due to the government regulation of industry and commerce; secondly, it leads to fatal contradictions of the unlimited production growth, which ignores the limited resources of the Earth; third, the "moral rules" in the basis of the market economy are of the uneconomical origin, which causes a fatal collision. In the result of the complex interaction of these factors by the end of the twentieth century the free market paradigm has given way to a mass consumption paradigm with the market relations but of the inferior order.

The era of the spontaneous action of market mechanisms is gone, making way for the era of air sellers and dream catchers. Now this megatrend identifies market importance of some factors and phenomena. Although the consumption is an essential attribute and even imperative for each individual and social existence of a man a thorough consideration about this phenomenon is just beginning to gain momentum. In particular, philosophers (Tulmin S., 1984) contemplate about the evolution of consumer forms, analyze consumption as a function of culture and mentality, ideological lines, and the underlying marketing technologies; psychologists are interested in the unconscious, spontaneous, a balance of rational/irrational in the consumer practices; sociologists prefer social factors and patterns of consumption: needs, motives, advertising communications, etc.

J. Baudrillard (2006) had a right opinion: "People in the community of well-being are surrounded by not other people but by the objects of consumption. Their daily communication is not just communication, but getting more, in accordance with the rising statistical curve, benefits from very difficult household and dozens of technical slaves until all the material machinery of communication and professional services, permanent spectacle of the glorification of the object in advertising and in hundreds of daily messages, which are produced by the media, filled with meaningless aggregate intrusive gadgets and symbolic psychodrama that's been haunting us even in our dreams".

As J. Baudrillard (2006) noted, "complementary myths of wealth and needs have a strong ideological function of blurring, elimination of the objective social and historical differences and inequalities. The whole political game Welfare State and a consumer society means to tackle inequalities through the growth of wealth, the prospect takes the form of automatic equalization by means of the amount of benefits and the achievement of the equilibrium level, the level of total welfare for all.".

Z. Baumann (2006) said "Aldous Huxley and George Orwell startled the Western world with two very different options of the coming social transformation. Both painted pictures of self-contained worlds, the worlds that are familiar with the conflicts as anomalies or eccentricities, and the few dissidents are hidden out of sight. In all other respects the worlds of Huxley and Orwell were significantly different from each other. Huxley created his world based on the experience of the pioneers of free consumption. Orwell, on the contrary, borrowed inspiration from the turmoil of the first renegades of the free market. Huxley gives the picture of a generalized prosperity, the search for pleasure and happiness; Orwell pictures a generalized (albeit suppressed) anger, struggle for survival and fear. However, the result is generally the same: it is about the society confident in its own identity, invincible before the attacks, able to keep its luster and poverty to infinity. In Huxley's world people rebel because they don't want; in Orwell's world they do not rebel, because they cannot. Whatever the 
reasons for obedience are, both societies secured the eternal stability using simple (foolproof) and convenient (expedient) tools - the elimination of alternatives".

Finally, there is a third picture, "the laconic and sketchy compared to Huxley and Orwell, but it penetrates into the very essence of the system bonded together by the consumer freedom. This picture appeared due to the Franciscan priest Francois Rabelais and his satirical masterpiece "Gargantua" - the book, which ends with the construction of Thelem Abbey. Thelem is a place of a pleasant life; wealth is the highest moral virtue, happiness is the basic precept, pleasure is the goal of life, the taste of the main craft, fun is the highest art, fun is the only duty. But Thelem has not only a sensual enjoyment and the thrill of unexplored pleasures. Most notable Thelem's characteristic is its thick walls. Inside no one has to worry about the wealth, happiness and entertainment; this is the price of a constant and rich accessibility. No one sees the "other side". No one is trying to see it: in the end, it's the other side...

Z. Baumann (2006) said: "The society, organized around consumer freedom, can be represented as a graceful version of Thelem. Thick walls are an integral part of a consumer society; as well as their invisibility to the inhabitants. If these walls come into the view of consumers, they are only a backdrop for colorful, aesthetically pleasing graffiti. All the ugly is behind the wall: factory sweatshops, workers without unions and insurance, the misery of life, bad skin colour, agony because nobody cares about you and you are unwanted. Consumers rarely notice this other side. They drive in a comfortable, plush interior of their cars through the squalor of the urban ghetto. If they are ever in the third world, it is only for Safari and massage rooms but not for sweatshop factories. The residents (insiders) of the consumer society think about strangers (outsiders), sometimes with fear, sometimes with censure; at best, with pity".

John Neisbit (2003) rightly observed that the trends are like horses: they are easier to go where they are ready to go. Such a feature spreads on mega trends to an even greater extent. The tip of the problem lies in the fact that despite the undoubted objectivity and regularity the mega trends can have negative and even fatal consequences not only for individual social and cultural ecumene but also for the mankind in general. In such a situation to be an inertial object which decided to exploit the "horse-drawn power of mega trends" is to act at least recklessly and irresponsibly. For this reason Neisbit wrote: "Our inability to see and our tendency to deny even what we see are quite natural, since the truth is too caustic and frightening". Thus the behavioural priorities of mass consciousness can be somehow explained but not justified.

The epicenter of the ideological tension today is to recognize the triumph of the theory and practice of radical hedonism, which due to its tranquilizing effect sometimes even leads to the atrophy of the self-preservation instinct. E. Fromm (1998) not accidentally drew attention to the fact that to be and to have are two main old ways of human existence. The problem is that "many people believe possession to be the most natural way of existence and even the only acceptable way of life. In this context, it is necessary to understand the essence of being as existence, or at least to understand that possession of anything is only one of many possible life orientations". Therefore, if possession (to have) always refers to the quantitative parameters and operates with the width of life, the being of the individual (to be) deals with the quality of human life. If to be is genesis, to have is the oblivion.

The power of happiness concept «is not provided by the fact of natural tendency of each individual to realize happiness potential. The fact that Happiness primarily had an appropriate ideological function results in important implications that relate to its content: to be a guide to the egalitarian myth, Happiness must be measured. It must have the form of the 
welfare, measured by things and status, "comfort," as Tocqueville said, who already noted the tendency of democratic societies to an increasing welfare as a way of tackling social fatality and uncertainties on the background calls of destiny" (J. Baudrillard, 2006).

In "Paradox of kleptocracy happiness" K. Fedoryshyn drew attention to the phenomenon called "money does not bring happiness" that is a simplistic understanding of "Esterlin paradox". In the second half of the twentieth century Richard Easterlin started quantitative measurements of the happiness level of citizens depending on the level of welfare of the nation. The results of his work created the aforementioned paradox. In short, the people with an income above the average are happier than those that are below the average one; but it should be up to a certain level of welfare, when all basic needs are met, the income growth gradually ceases to affect the feeling of life satisfaction. In other words, the poor up to a certain limit feel happier when their incomes rise, but should they reach the average level of income; the happiness dependence on the money will not work. The same applies to the economic growth in the country as a whole. After overcoming the poverty barrier the dependence of the happiness of the citizens from the economic prosperity of the state tends to zero. According to Esterline the reason for this is ambitions and desires growing in parallel with rising incomes.

It turns out, the more you can earn/steal, and the more you want and need. And if it brought happiness, now it cannot. The sense of dissatisfaction remains. This is similar to the successive increase of drug doses, so each time to achieve the same effect, it is necessary to increase the quantity of a substance. It is necessary to spend more money to buy it, the health is getting worse, and a former high, as in the beginning of addiction, is harder to catch.

In carrying on the work plane, abstracted from kleptocracy, this problem is expressed in the insatiable desire to earn more, disregard evrything, except for capital growth. Ambitions grow along with income, also the level of desires and hunger in a broad sense rises, the former high and sense of satisfaction requires more and more efforts. The result is stomach ulcers, early heart attacks or a spent budget to cover a year of reasonable cost.

The motivational mechanism of an advertising image impact includes, firstly, an appeal to the imitation of (following the pattern) which is achieved by techniques of the reference leaders use and typification techniques (identification with the image or its elements), and secondly, the appeal to consumer motivations. The main consumer motives include the motive of achievement, the motive of involvement in the group, a motive power, freedom, games, comfort, convenience, collectables, prestige, respect, patriotism, tradition, aesthetic, communication, security, educational, spiritual, friendship and love, sexual relations, avoidance of failure, physiological satisfaction, professional growth, saving (money, energy, time), personal development etc.

Since then scientists have repeatedly tried to refute the Esterlin paradox and someone even confirmed it. But the work of Ed Diner (2001) and a group of scientists added an intrigue. Scientists noticed that although the satisfaction with life depends on the revenue growth and the person must be positive for this, that is, should be happy that has "here and now", and, in general, should have an optimistic attitude to life. In this case, the increase in profits, which in many cases only results in apathetic shopping of new collections, makes the optimist feel satisfaction. For states in general, the Easterlin advice sounded simply: after a certain level of welfare the government should pay attention to non-financial factors that can give citizens a sense of happiness and overall life satisfaction in particular".

Mass culture appears to be a new system of control and manipulation of minds, interests and needs, consumer demand, value orientations and behavioral stereotypes, which ultimately is equivalent to the representation of its ideological and social loyalty to the 
existing order. As E. Fromm (1998) noted aptly, "hypnotic techniques used in advertising and political propaganda significantly threaten mental health, especially expressive and critical thinking and emotional independence. I have no doubt that a thorough investigation will prove: the use of drugs is much less injurious to health than the different methods of brainwashing, from subliminal suggestions to such semi-hypnotic techniques like constant repetition or a distraction from rational thinking by means of appeals to sexual pleasure".

A significant characteristic feature of the modern society of mass consumption and its manipulative technologies of temptation is the particularity that "for the first time in history the satisfaction of the need for enjoyment is not a privilege of the minority but is available for a growing part of the population. However, whether the achievement of pleasure (as a passive affect opposed to the active one) can be an acceptable response to the problem challenge of human existence - that is up-to-date question during the biggest social experiment. In industrialized countries this experiment gave a negative answer to the question" (E. Fromm, 1998).

The question about the meaning of life in general and humans in particular is a key ideological issue. The meaning is a cultural fact, a cultural product. J. Baudrillard (2001) in "System of things" work convincingly substantiated the thesis that things do not have independent contents but have the common function of signification (the thing acquires any sense in the semiosis process, that is, a man gives a certain sense to the things). The meaning is always the value that occurs in the act of social interaction. Baudrillard notes that we live in the symbolic sphere as well as consume only symbolic forms of things. "The modern things that are in the power of the functionality phantom have the mystery of transformation and function mutation. Ultimately expanding the meaning, the thing steadily impoverishes it. As a result, the thing is desemanticized. This feature explains the term "les gadget" that denotes a thing with a hidden function which cannot have a name. The name is a sign of individuality and the thing with an abstract value cannot be named".

M. Kagan (1996) argues convincingly that the process of differentiation of practical and symbolic, utilitarian and valuable properties of things in the culture gradually led to the identification of two classes of objects: first, purely technical and prosaic, every day, secondly, ritual, endowed with special religious and subsequently political values, an aesthetic value and artistic expression (a hat - a crown, the cap of Monomakh; a chair - a throne; clothes - cloak, etc.). "The gradual autonomization of the semiotical and axiological forms of the things functioning in the the culture, on the one hand, made certain things practically useless and, on the other hand, rather valuable, sacred, politically outstanding".

As Sirov V.N. (2010) A visual and aural perception of a mass communication by a modern man are exposed to the hyper-reality, simulacra created. There appears the "world of pure colors and sounds, clearly written details which have an improved clarity, brightness and contrast of the image. As a result, the photo in the magazine has a more attractive appearance than the original, the sound on the album is cleaner and more juicy than in the "live performance".

An important theoretical and conceptual aspect and ontology trend of modernity is the globalization of culture and the influence of globalization on the culture universalization. Following samples, borrowed from other cultures, has certain objective and subjective limits: it needs to be supplemented by the elements of an individual style. To unite humanity into a single harmonious whole dialogue between East and West is becoming more critical. Despite the importance of the cultural dialogue between East and West the interaction of cultures of individual nations is also rather problematic, instructive and depends on our present. 
The fact that the noosphere is a global phenomenon and requires recognition of the humanity as a single organism does not mean that culturally all peoples must sooner or later unite in some mega-culture, making a sacrifice of their own unique national cultures. This situation is both inappropriate and impossible. However, this temptation was, and probably will remain with the powerful. In fact, the path to the unification of humanity in the cultural dimension of the noosphere is through the dialogue of local, national cultures.

The researchers prove that the most common symptom of a society in a modern format is global processes and trends. However, the globalism is not included into a list of fully autonomous historical-cultural phenomena: it is a prerequisite for certain causal relationships that led to a high level the dynamics of global interaction and the lack of alternatives to the mainstream development. We are talking about the mass consumption society and, in particular, its structural components, as mass culture, mass media and the mass of people. To sum up, there is an evident cumulative effect of the mass factor for the phenomena and processes genesis prevailing in the modern society.

An adequate understanding of popular culture can be obtained by placing it in this context: mass society, mass production, mass consumption, mass communication. The most important attributes of a mass culture derive from them and are noted by different researchers: 1) oriented to a large audience, that is why, on the one hand, maximum standardized and on the other is aimed at the standardization of the mass taste; 2) implemented on a large scale that requires a specific infrastructure; 3) has a commodity status and market turnover; 4) broadcast media.

Modern means of mass communication have become a main translator of the new culture. Cinema, Internet, popular literature have become the main type of leisure of a modern man and are increasingly making a decisive influence on the people's minds. The images of popular culture have entered our lives, capturing the ordinary individual in the communicative practices at all levels, in an intriguing game that provides the modern society with more and more distinct signs of the "theatre society" (I. Hofmann).

The media creates a rich data sphere around an individual that it has a direct impact on the personality. The civilizational dynamics needs a certain format type of a person able to solve problems, updated and sharpened by the course of the social development. A global fashion for certain music, clothing style, behavior, etc emerge due to the media globalization, computer networks and easy information access. Meliukhin I.S (1999) noted that "the intense formation of new behaviour models and norms can be discussed at the higher level". Describing this situation, M. Knyazeva (1996) distinguishes four stages of cultural modus: passive, consumer-entertainment, active-receptive and creative.

The consumer and entertainment cultural position becomes the most widespread and typical in the mass society. Among its manifestations M. Knyazeva emphasizes one ambiguous innovation for our cultural life, a kind of cultural mutation, which arose in the depths of the information society and can be recommended by the information mania and a man, bearing features of the relevant behavior is an information addict. The information mania is a byproduct of the information systems development and the expansion of the information space. An information addict is a person for whom information moved beyond its natural functions that is knowledge and orientation, becoming an end in itself. The information has become a goal-in-itself not in the mind of the information addict but as a result of the logic of their own development.

Excessive information consumption is characterized by both excessively large volumes and excessive dynamics, flow. Hence the impossibility of assimilation and processing of the information received. As a result, there appears a counterproductive cultural activity, where 
the process is everything and the goal is nothing. An insatiable thirst for information is due to the consciousness mosaic. This consciousness has a structure, internal logic, stud. It may not be complete, so the knowledge does not bring the sense of intellectual clarification, does not end in gnoseological, epistemological and existential catharsis (Knyazeva M.L., 1996).

Modern culture appears to be a complex interactive symbiosis between the various subcultural systems which due to the effective and reliable communication channels direct the relationships of people in a society. The crucial role among these channels belongs to the media. The ability of media to influence social stock of knowledge (P. Berger and $\mathrm{N}$. Lukman) always used the authorities as an instrument of manipulation of a society. This ability of mass media is more valuable for the authorities due to the media public; it is easier to implement the ideological function of culture when object of influence is less educated and intellectually passive.

M. Manyahina (2012) is right saying that "the currently predominant technological culture significantly altered the entire way of life. Its basis is a cliché, the stereotype, the matrix, and the most adequate form of expression is a conveyor manufacture, trade, computer calculation that is, forms that devalue and erode individuality, originality. A man is trapped in a mechanistic system which operates on the principle of infinite self-renewal that is the replacement of old elements by new ones. The new in this system does not necessarily have to be better than the old. This system generates a type of mass consciousness, the core value of which is the consumption of new things.

G. Debor (2000) noted, "in its entirety the performance is both the result and the project of the existing mode of production. It is not some supplement to the real world, a superstructure to it or decoration. This is the heart of the unrealism of the real society. In all its manifestations whether it is information or propaganda, advertisement or direct consumption of entertainment, the play constitutes the model of a dominating society lifestyle. A play is the omnipresent adoption of choices that were already made in production, not to mention the subsequent consumption. The form and content of the play is an excuse for the conditions and objectives of the existing system".

M. Manyahina (2012) noted that justification for replacing of the old with the new and conviction in the advantages of the new is the field for advertising. Its main slogan is "you have to desire and be desired". It is the advertising that determines the value of things: the more often advertising is repeated, the "better" and "more valuable" is the thing for the stereotypical mass consciousness. So art with its super value of personal and special is substituted by the craft changed later by stamping, as only mass production of values can meet mass requirements: if I cannot have "Gioconda", I can own a tie similar to the President's one, a car like a neighbor possesses or the dress of the television presenter. In the modern culture of consumerism it is exactly advertising that defines the horizon of human needs, forming the desire for the infinite "life update".

As convincingly J. Baudrillard (2001) proves, the semantic focus of the discourse of things in a society of mass consumption is formed and significantly enhanced by advertising. Advertising not only provides information on value-semantic content of the discourse of things but also manages the process of sense generation and sense consumption. In the modern society advertising discourse has become a domineering force that, on the one hand, determines the priorities of mass consumption, manipulating public consciousness, and on the other hand, due to its compulsive nature causes the audience's resistance reaction: "Advertising discourse leads to the frustration condition not less than convinces that a user, if not acquired immunity against it, at least, feels free enough with regard to them". Advertising discourse has a specific type of language, the key concept of which is "brend". Within this 
language, J. Baudrillard argues there is a "miracle of psychological label," which by means of subconscious influence imposes the consumption of certain targets (consumer emphasis) discourse.

In the society of mass consumption, the language of advertising with the features of the power discourse, which controls the psychology of fashion consumption, becomes especially important. Baudrillard (2001) made a semantic revision of the "consumption" concept, focusing on his involvement in sign systems, discourses «Consumption is not a material practice and phenomenology of "abundance", it is not determined by the food people eat, clothes worn or the car being used, neither speech or visual content of images or messages, but only how it is all organized in a landmark substance: we are talking about virtual integrity of things and messages that make up the discourse. Consumption is an activity of systematic manipulation of signs".

Consumption is an integral part of symbolic exchange, the main object of which are sign systems (symbolic forms). The main catalyst and integrator of symbolic exchange is the discourse of marketing, which mobilizes advertising discourse and other discourses of mass communication. In the discourse of marketing there is a confluence of economic, political and media power resources. The mass media discourse is a powerful element of marketing discourse. J. Baudrillard (2001) formulates this point as follows: "Throughout the XIX$\mathrm{XX}$ centuries the political and economic practice became homogeneous that is turned in a single discourse type. Propaganda and advertising merged into a single process of marketing and merchandising of ideas and things that influence the masses. Such language conversion between economics and politics is characteristic of the society with the political economy. But at the same time it is also the end of political economy as both areas are mutually canceled in very different medative reality (hyper-reality)".

Culture is a complex symbiosis of different interacting systems twhich due to the effective and reliable communication channels govern the relationship of people in society. The crucial role among these channels belongs to the media. Functions of mass media and mass culture closely interact, are largely duplicated by regulating social life. Communication means make the reality model clearcut and the communication is one of the most important components of modern society. Shaping the information space, the media nowadays are the most effective tools of formation of the society value orientations.

The peculiarities of the current situation include dynamics, inequality, and contradictory development of a society. People are increasingly losing the sense of the criterion certainty. New life for the ordinary consciousness of a man is a source of anxiety and at the same time new chances. In the end, in each case, the person faces the necessity of solving the problems of adaptation to new conditions of life. Adaptation types are different, namely environmental, professional and social.

Popular culture and the media provide socialization and vitality of a man in the complex environment of a modern society, learn new social roles and values, ways of regulation of behavior and activity in the contradictory and ambiguous situation, help to cope with conflict situations.

Popular culture is the expressive attribute of mass consciousness and the imperative of mass consumption society. Although its essential segments and features were studied by many philosophers of the previous few decades still many aspects remain on the periphery of the research attention. First of all we are talking about historical types and patterns of evolution, mass culture, about the interdependence of mass culture and societies of different types.

In a modern society, which is rapidly developing and marked by a high level of social stratification, popular culture becomes a mechanism of socialization and begins to fulfill the value-orientation function. In post-industrial society influence on mass consciousness is carried 
out by using communication technologies, including network, allowing straightforward power strategy to replace the hidden, implicit, and "manage" - "temptation" (J. Baudrillard), or "machines of desire" (G. Deleuze, F. Guattari).

According to the J. Baudrillard, hyper-reality is formed in the post-industrial society within which the market economy loses its defining functions, giving way to the economics of desire and symbolic exchange. For the market success of a product (whether it is a thing, a work of art or socially important information) the seduction techniques are used which have replaced the dominant techniques in the past of an open submission as their soft-version. The essence and purpose of seduction of the masses in a modern society have been comprehensively delineated by J. Baudrillard (2000) in the work "Temptation".

The thesis, according to which the age of the postmodern mass culture becomes a powerful tool of seduction, obviously does not require an extensive argumentation. This type of culture appears to be a new system of control and manipulation of minds, interests and needs, consumer demand, value orientations, behavioral stereotypes, etc. that ultimately is equivalent to the representation of its ideological and socio-political loyalty to the regime.

Ideological function of mass culture is its ability to convince consumers of the views, ideas, and representations, which construct an understanding of reality. The modern individual, even being well-educated, remains an expert only in any particular field. In other areas it requires the constant assistance of commentators, interpreters, teachers, journalists, advertising agents and other "guides" that will help him overcome the boundless space of information about community events, cultural innovations, development alternatives, and the like. In addition, "people need a means of taking excess mental stress which is the result of a massive informational impact and reduces complex intellectual problems to simple dual oppositions, giving the individual the opportunity to escape from social responsibility and personal choice. The mass culture implements these needs" (Shestov L., 1995).

The power structures of popular culture adapt to the needs of their governing by means of making appropriate value orientations and preferences, unification of consciousness, the justification of the existing economic and political reality and the like. A lot of science-oriented texts of mass culture contain ideologically accented comments that illustrate how mass "science" is marked, determined by the social environment. Nowadays, any random selection of mass cult of cognitive strategies appears to be "inventoried, classified and dismembered; therefore, it is possible to manage it (what is the real challenge of the system on socio-economic and private levels)" (Baudrillard J., 2001).

The transfer of any specialized knowledge on everyday speech cannot be outside the control of the authorities. Popular culture sells its translational function in the limits acceptable to the power structures of the trend. This script can correctly be called "the temptation of the masses by means of information messages." It is produced by the ruling political and economic structures, plays an important role in the modern era, when mechanisms of social control undergo transformation from open violence to latent seduction. The purpose of the latest seduction of the masses is to ensure the stabilization of the society through providing general knowledge of its members and forming in the minds of the masses ideologically favorable power structures of the world picture.

The appropriateness of use in this context of the term "seduction of the masses by means of information messages" is defined by the fact that the mass cannot spontaneously be interested in complex science and technology: their knowledge must be properly directed, curiosity must be provoked, and the interest in science must be stimulated. The seduction of knowledge is the particularity of the implementation of translational function of mass culture in the era of popularization of science, carried out by leading representatives of academic science. However, 
the analysis of the empirical material is that modern mass culture, as a rule, sells its translational function by science "profanation". This happens because of the lack of the tendency for intellectual reflection and intentions to obtain adequate idea of the world and as a result of reduction of the level of professionalism of the "translators" of specialized scientific knowledge, the reluctance of the producers of mass culture to finance high-quality scientific and popular products.

Methods and goals of "knowledge seduction" are identical to the methods and purposes of market promotion of any product or service. This designs the fundamental essence of advertising technologies on the process of translating specialized knowledge by mass culture depicted by J. Baudrillard (2001) in the work "The System of Objects".

In the functional and instrumental aspect the modern culture is extremely diverse. This feature explains why it is denoted by many terms: a global mosaic, popular, elitist, simulation... However, the most adequate conceptual equivalent of modern culture is its mass character, because the culture of a society of mass consumption can not a priori be mass one.

The culture of the turn of XX-XXI century is marked by the appearance of a number of new features and is developing in the framework of a qualitatively new paradigm. So today there is an urgent need for intensive philosophical reflection of contemporary culture, the definition of its basic characteristics, and the like. The culture of the turn of XX-XXI centuries is an important component of the modern information civilization, expresses its essence and is closely interrelated.

The period of the late XX - early XXI century is the epoch of the formation of a global culture. There was a great social revolution, the reasons of which are the enormous changes in the forms, ways and styles of life. The individual began to receive a huge amount of information by means of electronic communication and mass communication,, the number, form and content of social contacts changed. For example, if the first concerto by P. Tchaikovsky in the United States in April 1981, in Carnegie hall was attended by no more than 2000 thousand people, the first performance in the U.S. of the rock group "Beatles" in February 1964 in the same room attracted 73 million people due to the TV, in our days thanks to satellite television the audience of some concerts is more than a billion inhabitants of our planet.

As O. Drobisheva (2010) noted, "Mass culture is a form of functioning of social consciousness, adequate to the basic parameters of the day". If Karl Jaspers (1986) called the mass art as "the decline of the essence of art", J. Baudrillard (2001) insisted that all spheres of modern art "are in the phase of simulation".

Mosaic, fragmentation and stylistic fragmentation (or = incompatibility) have become one of the leading themes and principles of creation of objects of artistic culture (dodecaphony music, postmodern novel), and contemporary philosophy (shizoid subject by G. Deleuze and F. Guattari).

With the advent of new forms of communication naturally a new type of culture has been formed. A. Mole (1973) considered a modern culture to be mosaic: "In our time the knowledge is created from disparate passages connected with simple, mostly casual relationships, location, time of learning, concordance and the association of ideas... We will call this culture "mosaic" one, because in its essence it is random, composed of many contiguous fragments. There are no reference points, no really general concept, but a lot of the concepts, with considerable significance (supporting ideas, key words, etc.). This culture is not primarily a product of university education that is a kind of rational organization; it is the result of permanent impacts on us of a jumbled stream of random information leaving only fleeting impressions and fragments of ideas". Mosaic, fragmentation and stylistic fragmentation (or incompatibility) have become one of the leading themes and principles of creation of objects of artistic culture 
(dodecaphony music, postmodern novel), and contemporary philosophy (shizoid subject by G. Deleuze and F. Guattari).

The term "mosaic culture» characterizesnot modern culture in genera but its "table, designed to "screen" the individual consciousness" (in terms of A. Mole, 1973). Culture is interpreted by the french scientist as an «intelligent "equipment," which includes every individual at one time or another and the structure of knowledge which the individual possesses as a member of a certain social group". In this sense, the "mosaic culture" is almost the same as the "mosaic mind".

Supporters of post modernism often and quite convincingly call a modern society as a "dissatisfied society". This concept reflects the specificity of modern society in the context of production needs, adoption, diffusion and satisfaction of the claims due to them. It is not strange, the more powerful dynamics of production and meeting of the needs only add to a total dissatisfaction, regardless of the degree of satisfaction of a particular need. The dissatisfaction is a powerful motivational factor in the functioning of modern society. P. Berger rightly pointed that the trends where mythologizing, desacralization and secularization lead to a total distribution of "boredom of a world without God." In such circumstances, the aspect of meanings, values, ideas and ideals, capable of performing the function of the spiritual principles of the foundation of efficient public infrastructures are especially topical.

M. Veber noticed that we live in the age of uncertainty, disappointment and loss of illusions. Secular ideological and political constructions, utopias and religious doctrines of past eras have ceased to perform the function of mobilization of ideals. They are either exhausted meaningfully or argumentatively bankrupt or significantly weakened on the level of social praxis. Huge projects, taboos and visions no longer inspire and do not cause fear. They have lost the capacity because of total indifference to them. The very possibility and relevance of any ideological-programmatic and political-ideological constructions as the mobilization of ideals is under the uestion.

The current status quo in this area is characterized by the prevalence of improvisation and fragmentation, lack of the argumentatively persuasive concepts and generally clear articulateness. As a consequence, uncertainty trend, unpredictability and randomness of both local and global processes increase. It can be explained by the lack of a clear ideological basis of global trends generated by the combination of many social, cultural and economic factors, various combinations of which, in fact, cause inconsistent and unpredictable situations. A lot of hidden aspects contribute to the uncertainty of consequences, which together significantly increase the potential for conflict as within individual societies and between different nations, cultures, confessions etc.

The fundamental question is about the temporal boundaries of the formation and functioning of mass culture. The fact, that mass forms to a certain extent took place in different historical periods, is not a sufficient basis in order to provide the mass culture with the status of a permanent attribute of historical and cultural development of mankind. In our research, we proceed from the genealogical relations of mass culture with the latest incommunications technology; therefore, its temporal parameters are limited to the twentieth century and the present.

James Paul Gee argues that games motivate players to think about strategy to achieve their goals and confidently achieve them to collect, analyze, aggregate data, keep in mind a large number of factors, to maintain a balance between short-term and long-term objectives. The researcher puts the majority view under criticism that modern culture can lead to the worst line of human development, which concerns the dullness and degradation of a society under the influence of popular culture. 
Steven Johnson (2005) in his book "Everything bad is good for you: how today's popular culture is making us smarter" proves that modern culture as television and computer games, in contrast to the common belief, not stultifying the viewer, but rather, sharpen our mind. Johnson recalls that the banal stories of computer games are complex problem tasks for the successful solution of which makes the player monitor dozens of different parameters and control them; and in order to understand what is happening in television series one should have to keep in mind those same dozens of story lines and relations between the characters, their history, etc. Johnson's theory is the assertion that popular culture has become more intelligent, it improves the society, producing new trends and ideas. He opposes the perception of popular culture, which morally corrupts society and is a factor in its degradation. He contested this requirement, although not in a hurry to conclude that it has become superior to traditional culture.

The researcher (S. Johnson, 2005) defends the position of the importance of a modern pop culture. He argues that the appeal of video games lies not in the content (violence and/or sexuality) but in the "structure" of video games that stimulate certain centers of the brain. $\mathrm{He}$ also insists that modern television and movies have reduced the number of "flashing arrow" (a metaphorical name of the technique used in movies to attract a particular object or situation, which will be used later for plot development). This allows the audience to understand the story and the audience requires more cognitive work, focusing on the details to understand the plot twists and turns.

The phenomenon of mass culture as the main way of existence of culture in postindustrial society gives grounds to assert the totality of the spread of mass culture, which covered almost all spheres of human activity, as well as a permanent increase in the number of carriers of its values. Mass culture appears to be a specific way of mastering reality and adaptation to it. In a post-industrial "mass society" it manifests itself in the form of the phenomenon, which characterizes the specificity of the production and distribution of cultural values. The main features of mass culture is to focus on the tastes and needs of the "average man" commercial, in close association with the media as the main channel of the broadcast and consumption of its values. With its own symbolic code, mass culture creates a symbolic superstructure of reality, which is seen by many as a true reality or a full substitute.

A primitive interpretation of natural and social environment by the mass culture is easily perceived and assimilated by a mass individual who, as a rule, is not generally subject to a long and difficult search for the truth. This "light absorption" helps keep psychological, spiritual and even physical health in the conditions of the information explosion. Mass culture relieves painful for the individual problems of personal choice, giving him the opportunity to delegate the decision making regarding the truth or falsity of the received through the media information by various commentators.

In addition, mass culture actually performs the function of the placebo effect, giving the individual the opportunity to feel himself sufficiently informed and "modern". Self-esteem of the subject of cognition takes place, he has the sense of self-worth, the damages caused by inferiority complex as a result of the fact that on a subconscious level the individual is aware of his low ideological and intellectual level are partly compensated.

The peculiarities of the current situation include dynamics, inequality and contradictory development of a society. People have lost the sense of the criterion certainty. An avalanche increase of innovations for the ordinary consciousness of man is a source of anxiety and at the same time new prospects. In the end, in each case, the person faces the necessity of solving the problems of adaptation to new conditions of life. Adaptation types are different, namely environmental, professional and social. The media contribute to socialization in difficult conditions of our time, teaching effective methods of regulation of life in the contradictory and 
rapidly changing environment; help to cope with conflict situations. However, the question arises of the value of such a worldview, ontological and psychological "shock-absorbers": can the price we pay for such a placebo-effect be too high? In the end, there is an even more perennial question: do we have a choice?

In the Preface to the second edition of the "Essence of Christianity" L. Feuerbach argued: in our age, when in contrast to the real thing the preference is made to its image, when the original is replaced by the copy, the place of reality - by the view and the place of existence by its visibility, only the illusion is the status of holiness. The truth is profaned. Moreover, when holiness proportionally grows the truth decreases and illusion increases so that the highest degree of illusion represents the highest degree of holiness.

Mass c ulture is the culture accented by a consumer: it seduces by means of compensated wishes and spontaneous impulses, sublimated sexual needs etc. In post-industrial society influence on mass consciousness is carried out by using communication technologies, including network. This gives the opportunity to replace the straightforward strategies of power by hidden, implicit ones and "management"by «temptation" (J. Baudrillard), or "machines of desire" (G. Deleuze, F. Guattari). The express change of the manipulative mechanisms of mass culture occurs: it increasingly refuses from the accented technology of power in favor of hidden, latent soft-means to achieve goals, which gives grounds to its adherents to speak about the "democratic mass paradigm".

A conceptual emphasis by E. Moran (2007) is marked by a convincing argumentation: "We need democracy of the mind, not the democracy of a society of mass consumption which leads to the regression of democracy in result of blocking the release of the key issues of civilization on the level of political consciousness".

From the point of the present status quo, it should be noted that the prototype of the future United global culture is already there, is the so-called Western mass culture. It is, in fact, the first type of culture that has spread throughout the world. The reason that today, in fact, the Western (especially American) culture has received the status of the universal, in our opinion, lies on the surface. It is primarily the economic power of the United States, through which it was able to convey their culture to the world. Another reason is that this culture is in demand which respectively has the adequate offer.

The perspective thoughts on the future of global culture can be found in foreign works. In particular, V. Tabachkovsky (2001) in the article "Humanism and the problem of dialogue of cultures" cited the thesis by R. Uilk that "the global culture appears as a structure of the general differences... Structures and concepts such as human rights, ideals of beauty or organizing principles are becoming worldwide. However, their implementation, application in practice can have many options".

The outstanding target is the value system of the mass consciousness which obviously needs a substantial correction, more harmonious coordination of its transformation with the logic of the informational society formation. We should not abandon the fundamental principles of the national spiritual tradition. The value system and the latest varieties should reflect national organic spirituality. Only in this case it will prevent the deformation of a national system of values and destruction of social and cultural continuity.

\section{References}

Bard, A., Zoderkvist, J. (2004). Netocracy. New ruling elite and life after capitalism.St. Petersburg: Stockholm School of Economics. 
Baudrillard, J. (2000). Temptation.Translation from french by Alexei Garadzhi. Moscow: Publishing house Ad Marginem.

Baudrillard, J.(2001). System of things.Trans. from french by S.N. Zenkin. Moscow: Editorial URSS.

Baudrillard, J.(2006). Consumer Society. His myths and structures. Moscow: Cultural Revolution, Republic.

Baudrillard, J., Jaspers, K. (2007). Transparency of evil.The specter of the crowd. Moscow: Algorithm.

Bauman, Z. (2006). Freedom. Transl. into russian by G. M Dashevsky.Moscow: Center for Humanitarian Technologies. Avaliable at: http://gtmarket.ru/laboratory/basis/.

Debor, G.(2000). Society of the Performance. Transl. from french by S. Ofertasand $M$. Yakubovich. Moscow: Logos-Radek.

Drobysheva, E.E. (2010). Axiological analysis of the phenomenon of mass culture. Questions of Culturology. No. 2, 91-98.

Fedchenko S. S. (2015) Transformation of the phenomenon "mass": from the crowd to the selective user. Tambov: Gramota. № 12, part 3, 184-186.

Fromm, E.(1998). To Have or To Be? Psychoanalysis and religion. The art of love. Trans. from english. Kyiv: Nika-Center.

Jaspers, K., Baudrillard, J. (2007). The power of the masses. The specter of the crowd. Moscow: Algorithm.

Johnson, S. (2005). Everythingbad is good for you: how today's popular culture is actually making us smarteron. Riverhead.

Kagan, M.S. (1996). Philosophy of culture. St. Petersburg, AST.

Knyazeva, M.L. (1996). Man in the information space: the cultural modus of the individual. Library Science. No. 6, 79-86.

Manyakhina, M.R. (2012). Thing as a carrier of the mass media. Journalistic Yearbook. No. 1, 24-27.

Meliukhin, I. S. (1999). Information society: origins, problems, development trends. XXI century: information and society (ed. byYa.N. Zasursky). Moscow: Moscow State University.

Mole, A. (1973). Socio-dynamics of culture.Trans. from french by B.V. Biryukova. Moscow:Science.

Moren, E.(2007). Education in the future: seven urgent tasks. Synergetic paradigm. Synergetics of education. Moscow: Progress-Tradition.

Neysbit, D. (2003). Megatrendy. Moscow: Ltd. "Publishing House AST": CJSC NPP "Ermak".

$O^{\prime}$ Connor, J. (2006). The art of system thinking: the necessary knowledge of systems and a creative approach to problem solving. Moscow: Alpina Biznes Books.

Shestov, L. (1995). The apotheosis of baselessness (the course of adogmatic thinking). Works. Moscow: Rariteit.

Sirov, V.N. (2010). Mass culture: myths and reality. Moscow: Aquarius.

Tabachkovsky, V. (2001). Humanism and the problem of the dialect of cultures.Filosofska dumka.No. 1, 6-25.

Tulmin, S. (1984). Human understanding.Moscow: Progress. 


\title{
3.2. SOCIAL-INTEGRATIVE PARADIGM OF GLOBAL PARTNERSHIP
}

\author{
Olena Berezina \\ PhD (Economics), Professor, \\ Professorof the Finance Department, \\ Cherkasy State Technological University, Cherkasy, Ukraine
}

The United Nations Summit, held in the framework of the 70-th session of the UN General Assembly in New York became a historical event of the world importance. Topics of the Summit covered all aspects of socio-economic development, competitiveness, environmental and energy security, the global partnership for development and the substantial amount of preparatory work was unprecedented in history. According to the results of the Summit the Agenda for development until 2030 and seventeen Sustainable Development Goals, which are the main priorities of social development for the next fifteen years were adopted. Proclaiming a new era for national action and international cooperation, the new order of the day obliges each country to carry out a wide range of activities that will be aimed not only at addressing the root causes of poverty but also at improving economic growth and prosperity, meeting human needs in health, education and social security, environmental protection.

Speaking at the opening ceremony of the Summit, UN Secretary-General Pan Gee Moon noted: "The new agenda is the promise of the leaders of all people of the world. It is a comprehensive, integrated and changing vision to create a better world. This is the plan of action for ensuring universal prosperity, peace and partnership that reflects the urgency of the measures in the field of climate and is based on the gender equality and the rights of all people.

New Goals for sustainable development are based on the programs of the UN conferences indicating the aims and very successful Millennium development Goals, which have improved the lives of millions of people. In the new agenda it is stated that the world is facing huge challenges - from widespread poverty, growing inequality, and enormous disparities in opportunity, wealth and power to the degradation of the environment and the risks posed by climate change."Never before have world leaders promised to take joint action and make joint efforts to such large-scale and comprehensive political agenda", - stated in the Declaration adopted by the leaders. - "Together we go through sustainable development, devoting ourselves to providing global development and mutually beneficial cooperation that can bring enormous benefits to all countries and all parts of the world."

The President of the UN General Assembly Mogens Lykketoft called the Agenda of sustainable development for the period till 2030 to be an "ambitious" means to counter such injustices as poverty, marginalization and discrimination. "We recognize the need to reduce disparities and protect our common home by modifying transient patterns of consumption and production. We also identify a general need for elimination of policy section, corruption and irresponsibility which feeds the conflict and holds back development".

Recognizing the success of the SDGs, the outcome document of the UN Conference on the sustainable development (Rio+20) in 2012, entitled "The Future We Want", the countries agreed to establish an open-ended working group for the development of a package of sustainable development goals for further consideration and appropriate action.

The sustainable development goals (SDGs), proposed by the open-ended Working group is the result of a three-year transparent process, based on a broad participation of all stakeholders and consideration of people's opinions. Many stakeholders, especially young people, were also involved in this process from the very beginning through social networks and other platforms. 
Monitoring and analysis of the 17 SPGs and 169 targets of the new agenda will be implemented by means of a set of global indicators. The global system of indicators should be developed by the iInteragency and expert group of SDG indicators, will be agreed by the UN Statistical Commission by March 2016. The government will also develop national indicators that will help track the progress of goals and objectives.

The verification process and review will be conducted annually by the Political highlevel forum on the sustainable development on the basis of the report on progress of the the SDGs, prepared by the UN Secretary-General.

So, after a Summit the UN countries-members faced new challenges of adaptation of goals and their monitoring defined at the global level. Ukraine also began to establish sustainable development goals for 2016-2030 period, appropriate targets and indicators for monitoring of the achievement of the objectives. In his report at the Summit the President of Ukraine Petro Poroshenko noted that "...to achieve Sustainable Development Goals at the national level, Ukraine will implement new programs and projects, which in practice will ensure macroeconomic stability, ecological balance and social cohesion. SDGs will serve as a common basis for further reforms in Ukraine".

The goal of sustainable development in Ukraine will be a new system of mutually agreed management measures on economic, social and ecological (environmental) dimensions, aimed at the formation of social relations based on trust, solidarity, intergenerational equity, safe environment. Sustainable development is an inalienable human right to life and full development.

The new goals must integrate the efforts of economic growth, the pursuit of social justice and environmental management, which requires profound socio-economic transformations in Ukraine and new approaches to the opportunities of global partnerships.

Strengthening of the implementation means and revitalizing the global partnership is the 17 th sustainable development goal. According to F. Hayek, the modern integration process leads to "new interaction forms between the subjects of social development, resulting in the formation of new social institutions that violate the established historical logic of human existence". In our opinion, the emergence of such institutions by the nature of their operation can be identified as a global partnership.

It is noted in the Law of Ukraine "About the social dialog in Ukraine" (2010) that the main trend of a modern social historical development, which meets the conditions of globalization, is a union of separate countries, regions and continents into a new all-planetary reality. Based on this, the whole world is regarded as a "global, universal reality, which is based on the continuity of civilizational development through the continuous implementation of a unique single, regional-special phenomena with the direct production of diverse, contradictory differences by the civilization in the conditions of their confrontation, in which separate civilization forms vanished and at the same time the whole civilizations survived". Global integration provides the form of unity and integrity of the modern humanity, due to which different state aspirations and interests can lead to a global unity of the world. The basis of this unity is a natural solidarity as "a conscious, internal spiritually-morales and social organization that provides a universal common humanity". This suggests that the global integration is a necessary socio-historical condition not only of the modern world but the salvation of the mankind as a whole. However, the global integration as any other social structure can, under certain conditions, have both positive and negative effects.

The basis of the global integration is an all-uniting, global system of values (human, globalization, national, regional and individual), which, if necessary, must be approved by all subjects of the global unities. This value system is a priority with respect to the peripheral values 
and mainly should lead to averaging of neutrality in the value views, not to destroy the basic values motivating states in the integration process. Therefore, in the context of globalization we have to talk about the so-called "transnational system of values, which would work to integrate states, not to the opposition on the basis of differences in the national system of values of every state.R.V. Voitovych (2014) points out two main forms of global integration in modern conditions: the global integration of an individual and the global collective integration. The first describes the personal incorporation of the individual into the sphere of a global social, political, economic and cultural space. That is certain forms of associations between individuals in the global space are meant here. So, for example, the individual to realize his/her interests and needs is included in the relevant transnational structures (economic, professional, political, religious, social). In the conditions of information society development this can also be done by means of the Internet. The second one involves the Union of States as subjects of a collective will to implement common interests. These are economic, social, political, cultural, environmental, legal interests which determine the criteria of interconnection and interaction between states.

Common interests, according to the scientist, naturally define more prioritized forms of partnership in the context of the global integration than just neighborliness. The partnership is a subjective act of cooperation between the states on the basis of the common interests, whereas good-neighbourly relations is a form of association on the basis of common territorial factor. Quite often the interests between bordering states can be fundamentally different in this regard a global optimal form of integration between them cannot be taken into account. Therefore, the partnership is a prioritized form of interaction between states than neighborliness.

First and foremost, economic interests are the basis for partnerships, but in this study we will focus on the social component of the global integration. A prerequisite for global integration is a global process of mutual bonding of peoples. However, the process of mutual bonding, according to K. Zegbers (2016), "can be more dangerous to the identity of small peoples and nationalities. This refers to the establishment of primarily those norms and standards which still remain problematic for industrialised countries. A rough transplantation of norms and values in the public body can be devastating". Based on this, global integration can be an effective form of social development if it ensures the preservation of national identity and individuality. Each state becomes more powerful in organizational and legal terms, if it interacts with other strong countries and in a such mental variety it inevitably becomes more effective. The question here is mainly on the geopolitical level of a social unity and solidarity which provide a vital activity of any global unity. The global integration in any form should always be aimed at ensuring social solidarity, which gives the opportunity to build a new macro-structure of social relations within the global space.

The world experience shows that social progress largely depends on the balance between the goals of economic growth maintaining, business competitiveness, environmental safety and the reduction of a social inequality. To achieve long-term goals certain short - and medium-term objectives must be fulfilled. It should be noted that the main document that determines the motion vectors of Ukraine to the sustainable development was adopted in January 2015, the sustainable development Strategy "Ukraine - 2020" (2015). The aim of the Strategy is the implementation in Ukraine of European standards of living and entry into the leading position in the world.

Four main vectors of the progressive development of the country are defined in this document:

- the development vector is the sustainable development of the state, structural reforms and, as a consequence, raise of living standards. Ukraine should become a state with a strong economy and innovations. To achieve this, first of all, it is important to restore macroeconomic 
stability, sustainable economic growth by means of the environmentally mild way, to create favorable conditions for business activities and transparent tax system;

- the security vector is a safeguarding security of the state, business and citizens, the security of investments and private property. Ukraine should become a state capable of defending its borders and ensure peace not only on its territory but also in the European region. Ensuring fair and impartial justice, immediate cleaning of the authorities at all levels and effective mechanisms of fighting corruption must become the basis for the security. A special attention should be paid to the safety of life and health of a person, which is impossible without the effective medicine, protection of socially vulnerable layers of population, a safe environment and access to drinking water of a high quality and safe food products, industrial goods;

- the responsibility vector is the guarantee that every citizen, regardless of race, colour, political, religious and other beliefs, sex, ethnic and social origin, property status, domicile, linguistic or other characteristics will have an access to a high quality education, health care and other services in the public and private sectors. A territorial community will independently resolve issues of the local importance, their welfare and will be responsible for the development of the whole country;

- the pride vector is a mutual respect and tolerance in a society, pride in own country, its history, culture, science, sports. Ukraine should take its rightful place among the leading states to create the appropriate conditions of life and work for the education of their own talents, as well as attracting the world's best specialists in different branches.

To ensure a sustainable development of the state and the successful implementation of this Strategy 62 reforms and programs of the state development must be brought into action, among which tenpriority programs are outlined.

Undoubtedly, the successful implementation of reforms and achievement of all development objectives is good governance, eradication of corruption, public support. Accordingly, a social integration, good governance, honest and transparent government, public participation in decision-making and monitoring of their implementation, social dialogue is a fundamental to the sustainable development of a country and its regions.

Here we should dwell on the interpretation of the concept "social integration". The formation of the idea of integration comes from the theoretical discussions of the formative period of the sociology as an independent scientific discipline, the object of which is the society as a social organism. Kovalev A. D. (1994) noted, that the concept of "integration" was first introduced by the English scientist Herbert Spencer, a representative of evolutionism in sociology, according to which the development of society is equated to the development of living organisms. Social integration (from lat. integratio - replenishment) is a concept describing the set of processes occurring due to the connection of heterogeneous interacting elements in a social community, that is a the whole, the form of a support of a certain stability and balance of social relations by groups; the ability of the social system or its parts to resist destructive factors, self-preservation before the face of internal and external tensions, contradictions.V.I. Fetisov (2007) notedthat in sociology social integration is the most prominent process associated with the state of an inequality in a society, with the nature of its social structure and stratification. Irregularities cause a rise in claims, contributing to the conflict. If the latter is not mitigated by the development of the production and improvement of the distribution system, process of disintegration start to rise in a society. There is a relationship between the types of integration, which is very mixed.

Social integration (according to the "Sociological dictionary") refers to the condition and the process of unification of social phenomena into a whole, the coexistence of different elements of a society together, harmonization of relations between different social groups, their 
interdependence; spiritual, socio-political and economic unity of a society manifests itself in the creation of the values and ideals for all people; the existence of orderly relations between individuals, groups, organizations, etc; unity diversity; a characteristic of the degree of coincidence of goals, the interests of various social groups and individuals.

M. V. Mosiondz (2014) in the result of the methodological analysis of classical sociological approaches to understanding of a social integration identifies two lines of the phenomenon analysis.

1. Objectives tradition is focused exclusively on objective conditions and criteria of the social integration process. The doctrine of social integration was developed by O. Cont, B. Malinowski, E. Durkheim, T. Parsons, P. Merton, G. Simmel, L. Coser, G. Dubil, et.al, giving it different understandings and emphasizing various aspects.

2. Subjective tradition assumes the position that, in conjunction with the objective conditions one of the components of the process of social integration is a subjective determination, motivational structures and needs (M. Weber, P. Berger, T. Luhmann, K. Manheim, representatives of the phenomenological and constructivist directions).

According to the definition given by Raizberg L., Lozovsky E., StarodubtsevaB. in the "Modern economic dictionary"(2011), the integration is an association of economic subjects, deepening on their interaction, development of relations between them. Economic integration takes place both at the level of national economies of entire countries and between enterprises, firms, companies, corporations. Forms of manifestation of economic integration are expanding and deepening of the production and technological contacts, sharing of all kinds of resources, creation of favorable conditions for economic activities. The management aspect (according to Meskon M., 2008) of the integration concentrates on the following principles: a comprehensive implementation of the functions and management interactions; the process of bringing together a variety of subsystems (departments) to achieve the goals of the organization; actions aimed at a long-term convergence of the strategic interests of two or more entities.

In philosophyunderstanding of the integration as a qualitative characteristic of macrosystems (societies, cultures, and civilizations) is predominant. Cultures (or "civilizations") are considered to be closed, totally integrated organic units characterized by internal coherence of constituent elements, natural internal balance, embody some general principles, common "cultural configuration", specific "national ideas" or "collective spirit"(Culturology. XX century. Encyclopedia, 1998). In cultural studies this concept refers to "one of the basic concepts of a systematic approach to the study of a sociocultural reality; expresses the existence of coherence and interdependence between system elements, which provides the internal coherence of the system, its preservation, harmonious functioning, resilience and stability. Depending on the system under consideration (social, cultural and so on), the terms "cultural integration", "social integration", "sociocultural integration" are in use.

Social integration in the aspect of a sustainable social development is achieved through consensus in relation to the rules and norms of behavior of people occupying different social positions in society. As a result of joint activities of people to achieve sustainable development goals these goals acquire a normative status that is subsequently fixed in the mind and creates a sustainable identity not only of a separate individual but groups of people with a society. In modern conditions the performance of the social integration for sustainable development depends not only on understanding each person's goals of a sustainable development and whether he/she understands and shares these objectives, but also its "inclusion" in the process of achieving of these goals. Here we can partly agree with E. A. Durkheim (1990), who noted that a social integration has compulsory (mandatory) nature for an individual, but a society, in turn, must take into account the interests of an individual as it has certain duties. 
Thus, social integration for a sustainable social development must be understood as the process of unification of efforts and the harmonization of relations between different social groups and institutions, socio-political and economic cohesion to achieve the goals of a sustainable development on the principles of unity, diversity and harmonization of interests of various social groups and individuals.

Next, the most essential and effective (in the circumstances) tools of social integration, which make it possible at the level of individual administrative-territorial units to start/accelerate the process of a sustainable development. In our opinion, such tools are public-private partnerships, a social dialogue and citizen initiatives.

According to the Director of the Institute of Demography and Social Studies named by M. V. Ptukha of NAS of Ukraine, academician E. M. Libanova (2015), today there is an urgent need for a fundamental reform of the Ukrainian society and the Ukrainian economy in the context of increasing human development through the strengthening of the competitive advantages of Ukraine; the minimisation of threats, including those associated with the economic crisis; and the ultimate focus on the increasing of the living standards and quality of life. The crises - economic, political, military, demographic, environmental - will always occur at any policy. Vulnerability prevention is preparedness, the ability to endure and the willingness to overcome the effects through the formation of social responsibility of the government, business and population, in particular, the willingness and desire to choose their own path and be responsible for that choice. The main instruments for this involve building of long-term and medium-term development strategies based on the existing risks, decentralization of power, civil society development and priority investments in human development.

The authorities have already taken the first and essential step that provides opportunities for the development of local self-government that is the process of decentralization is initiated. One of the problems for the reform of the local self-government and territorial power organization in Ukraine is the weakness of their material and financial base and inability to perform the powers of local authorities.

The aim of the policy in the sphere of decentralization is to shift from the centralized governance model in the state, ensuring the ability of local government and building an effective system of territorial organization of power in Ukraine, the implementation of the full provisions of the European Charter of local self-government principles of subsidiarity, ubiquity and financial sustainability of local authorities. It will enable the efficient use of managerial and resource potential of the territory (regions and smaller locations (cities, associations of territorial communities, villages, towns)) to implement the strategy of sustainable development of Ukraine and improvement of the quality of life of the population.

The development of the territory, of course, depends on the assets that it owns and may dispose and the effectiveness of their use, which is usually reflected in the overall income derived as a result of this process. Assets of the territory (municipality (territorial communities of villages, settlements, cities, districts in cities) are defined through the law and communal ownership of movable and immovable property, revenues of local budgets, other funds, land, natural resources, enterprises, institutions and organizations, including banks, insurance companies and pension funds, the share in the property of enterprises, housing, non-residential premises, institutions of culture, education, sports, health, science, social services, and other property and property rights, movable and immovable objects, determined in accordance with the law as objects of communal property as well as funds received from their disposition.

In modern conditions the competitiveness of the territory is achieved through the integrated and effective use of its internal capacity. Improving the efficiency of the territory, in turn, provides for the capitalization of territorial assets, improvement of the investment 
attractiveness of the territory by creating integrated property complexes, the increase in value added created on the basis of deep processing of local resources, creation of value chains and inclusion of a local production in the external chain. But a significant part of the natural resource, socio-cultural potential of the territories is not used. It is necessary to create real conditions for the attraction of territorial resources and assets in the economic circulation and the formation of the investment-attractive property complexes that make a unique image of the territory and are subject to attracting external capital. In this context, it is the public-private partnership that is the basis for the balanced development of territories and the use of regional resources.

The basic condition for the sustainable development of the territory in the economic sense is the extended reproduction of capital which implies the embedding of the municipalities in the outer system of capital movements and the creation of such conditions under which certain areas would benefit from the placement of certain types of economic capital and generating on their basis of their own value chains.

The use of tools of public-private partnership provides the opportunity to satisfy the territorial needs of a social nature (provision of available services corresponding the international quality standards, including environmental), a more modern and high-quality service level at no additional cost. At the same time, the success of any development project is the creation of partnerships between a customer and contractor. In addition, such projects are not only a new way of project funding; they provide an opportunity to maximize the management experience, commercial and creative potential entrepreneurs.

Incentives for attracting parties to public-private partnerships: business organizations: ideological, economic, and fiscal incentives; the cost of the project in the prescribed proportion; minimum rate guarantee; risk allocation; local governments and regional governance: the lack of capital (and possibilities) to attract debt resources; limited tax base; the shortage of funds in real terms (lack of capacity to maintain existing infrastructure, while the demand for infrastructure services increases); a positive budgetary and socio-economic impact; attracting funding from the private sector to direct budgetary funds released for other purposes; lack of budget operational costs; transfer of risks to the private investor; to the territorial communities: the possibility of solving current problems and improving the quality of life even in the face of limited resources.

Public-private partnership can be realized in different forms: concession; joint activities; product distribution; other treaties, the most promising form of such partnerships in transformational terms is a concession. Under current law, such projects may be carried out on a contractual basis with a mandatory formalisation of all important conditions of the agreements between the parties in a written contract. It should be noted that in some European countries there is no such restriction, mainly a special structure in the form of a legal entity with the participation of public and private partner, in some cases with the participation of financial institutions. In such an association the contracts are concluded and it helps achieve a maximum structure and the transaction transparency. In Ukraine, in our opinion, formalization of rights and obligations of the parties in public-private partnerships in the form of the contract is justified.

Thus, on the principles of public-private partnerships between public institutions of a separate administrative-territorial unit systematic, structured and mutually beneficial relations are build aimed at improving the quality of life of the population and sustainable development of the area.

The following social integration tool for sustainable development is a social dialogue. According to article 1 of the law of Ukraine "On a social dialogue in Ukraine" (2010), the social 
dialogue is the process of identifying and convergence towards common agreements and concerted decisions by the parties to the social dialogue that represent the interests of workers, employers and executive bodies and the bodies of local self-government, on issues of formation and implementation of state social and economic policy, regulation of labour, social and economic relations.

One of the major current tasks is the formation of effective national systems of social dialogue and reform of the social sector. Today this system includes an extensive legislative base, modern institutions and forms of interaction. The legal framework for the social dialogue is the Constitution of Ukraine, Code of Labor Laws of Ukraine, Civil Code of Ukraine, Laws of Ukraine "About social dialogue in Ukraine", "About public associations", "About trade unions, their rights and guarantees of their activity", "About organizations of employers, their associations, rights and guarantees of their activity"," Aboutcollective contracts and agreements"; "Aboutthe procedure for settling collective labor disputes (conflicts)", and also Decrees of the President of Ukraine, regulatory legal acts of the Cabinet of Ministers of Ukraine, Ukraine ratified the Convention of the International labour organization, European social Charter. The parties of social dialogue are involved in the legislative process, providing suggestions to the draft laws of Ukraine, regulatory legal acts of the Cabinet of Ministers of Ukraine and other state institutions. According to the Law of Ukraine "About the social dialogue in Ukraine", the national tripartite socio-economic council and the regional councils, which actually contribute to the consolidation of the social partners.

The main forms of the social dialogue, which are now being implemented in Ukraine, is the exchange of information, consultation, collective bargaining, the content of which is to develop and coordinate the positions of the parties. The most effective form of the social dialogue, which influences the level and quality of life of citizens, is the conclusion of collective agreements, primarily at the national level.

We partly agree with Fetisov V.Ya. (2007) that nowadays the national system of the social dialogue does not perform assigned tasks at the appropriate level. The main factors for this situation are: the low institutionalization of existing subjects of the social dialogue; the lack of mechanism of implementation of decisions; pretentiousness, formality, failure to comply with collective agreements and contracts; the objective failure of organizations of both employers and trade unions to cooperate with the organs of central and local authorities; weak involvement of a civil society in the process of a social dialogue. In the context of European integration processes of Ukraine, the activities of all social partners are characterized by the lack of attention to the environmental policy aspects of socio-economic impacts on the employment and labour market issues to ensure the competitiveness of enterprises.

The transition to the environmentally sustainable and socially oriented economy causes a reorientation of the principles of growth with the goal of providing an meaning of economic, social and environmental aspects. For the development of enterprises and labour markets, the clean economy today is already a necessity and not just a matter of choice, since it can actually lead to a higher employment, significant improvement in the quality of jobs and increase of income equality and social integration. It is underlined at the same time in the international documents that it is impossible to achieve the goals and objectives of the sustainable development without the active participation of the parties concerned, including labour.

Social dialogue provides a successful transformation towards a green economy due to active work with the social partners that can play a key role in productivity improving. This is achieved by distributing the responsibility between workers and firms, to inform national systems and institutions about the implications of the transition to a green economy, motivation, 
and organization of professional development and training, the transition to a green economy with the respect for labour standards.

The government, business and industry should promote the active involvement of workers and their trade unions in the decision-making process for the design, implementation and evaluation of national and international policies and programmes on the environment and development, including the field of employment policies, sectoral policies, structural adjustment programmes.

Thus, a public-private partnership and social dialogue are promising tools for social integration for the sustainable development. One of the main tools of implementation of the sustainable development may bea social dialogue of the advanced format, based both on traditional and new forms of cooperation between governments, organizations of workers and employers, between the public and private sector and civil society organizations - in order to maximize the quality of life of people both at present and in the future, while ensuring an economic, social and environmental sustainability.

\section{References}

Culturology.XX century.Encyclopedia (1998). T. 1. St. Petersburg: University book; Alteya. Durkheim, E. (1990). About the division of social labor.Method of sociology. Trans. from french and the afterword by A. B. Hoffmann. Moscow: Science.

Fetisov, V. Ya.(2007). Social life as a subject of sociology research.Sociological research. No. 6, 36-40.

Historical new world order in the sphere of sustainable development was unamously adopted by 193 UN member states. Avaliable at: http://www.un.org.ua/ua/informatsiinyi-tsentr/news/35792015-09-28-12-06-08-istorichniy-noviy-poryadok-den.

Kovalev, A. D. (1994). Modern western sociology. Moscow: Science.

Meskon, M, Albert, M., Hedouri, F. (2008).Fundamentals of Management. Trans. from english. Moscow: Williams.

Mosiondz, M. V. (2014). Practices of social integral of contemporary youth in the Ukrainian society: monograph. Ministry of Education and Science of Ukraine.National Mining University. Donetsk: NMU.

Raizberg, B., Lozovsky, L., Starodubtseva, E. (2011). Modern economic dictionary. Moscow: Infra-M.

Sociological dialogue and sustainable development: the order of the day for the civil society. Avaliable at: http://bureau.in.ua/index. php / news / 147-sotsialnij-dialog-i-stalij-rozvitokporyadok-dennij.

Sociological dictionary. Avaliable at: http://enc-dic.com/sociology/Socialnaja-Integracija8365.html.

Sustainable development goals. Avaliable at: http://www.un.org.ua/ua/tsili-rozvytkutysiacholittia/tsili-staloho-rozvytku.

Sustainable development strategy "Ukraine - 2020" Avaliable at: http://zakon5.rada.gov.ua/laws/show/5 / 2015 \# n10.

The Law of Ukraine "About social dialog in Ukraine "№ 2862-VI dated 23.01.2010. Avaliable at: http://zakon2.rada.gov.ua/ laws / show /2862-17. 


\title{
3.3 INFORMATION CHALLENGES FOR SUSTAINABLE DEVELOPMENT IN THE CONTEXT OF FORMING INTERNATIONAL COMPETITIVENESS
}

\author{
Yuriy Vdovychenko \\ PhD (Economics), Associate Professor, \\ Associate Professor of the International Economics and Business Department, \\ Cherkasy State Technological University, Cherkasy, Ukraine \\ Marina Leshchenko \\ PhD (Economics), Senior Lecturer of the International Economics and Business Department, \\ Cherkasy State Technological University, Cherkasy, Ukraine
}

The current model of industrial development with every year more clearly demonstrates that environmental protection is more directed at combating the effects that destroy the environment, and not with the causes that create them. That is, the symbiosis "man and the biosphere" has evolved from the mutually beneficial coexistence of the coexistence of one system at the expense of another. That is why it is necessary to redefine the human development model and move on to the goal of achieving a balance between all functional systems.

Sustainable development is a development that meets to the needs of the present, without compromising the ability of future generations to meet their own needs. Sustainable development continued to evolve as a defense of global resources, while its real program controls global resources. Sustainable economic growth means economic development that meets to the needs of all people, without leaving future generations with less natural resources than those we like today.The essence of this form of development is a stable relationship between human activity and the natural world, which does not diminish the prospects of future generations to live a life which quality is no less than the present.Sustainable development is a process of productive forces harmonization, ensuring satisfaction of the necessary needs for all society members, provided that the environment integrity is preserved and gradually reproduced, creating of opportunities to balance its potential and the requirements of society. The basis of sustainable development is the parity of the relations «man - economy nature»which contributes to the transition to such an interaction of this triad, which is called the era of the noosphere. But the most significant period of the foundations of sustainable development formation began with the 60s years of the twentieth century, when in 1962 Rachel Carson wrote the work of «Silent Spring» (for the first time raised the issue of global environmental problems) and in 1968 Italian economist A. Peccsi The Roman Club was founded.

In 1972, the Rome Club, an international group of academics, civil society, diplomacy and industry, published its first report «The Limits to Growth» (Meadows, D. H.; Meadows, D. L.; Randers, J.; Behrens III, W. W., 1972), which described the scenarios for the continuation of economic and demographic growth that led to to limit resources and increase pollution causing population collapse. In the same year, the first international environmental conference, which established the United Nations Environment Program (UNEP), took place in Stockholm.The World Commission on Environment and Development (WCED), headed by Norway's former Prime Minister Gr. Harlem Brundtland, was founded in 1983. The team consisted of state secretaries, civil servants and decision makers from 21 countries, tasked with finding solutions to growing environmental and development issues. Public polls were held around the world to get the widest possible vision of humanity's problems. In 1987, the group presented its results in the "Our Common Future»", also known as Brundtland Report (Brundtland, G., 1987). The report managed to highlight links between a number of issues that 
were previously considered separately, including development, global environmental problems, social problems, peace and security. The main attention is paid to the need for «sustainable development» as a development that provides the needs of the present generation without compromising the ability of the future generation to meet their own needs. This wording of this notion is now widely used as the basis in many countries.

As follows, sustainable development can be seen as a compromise between two different movements - the ecological movement and development and the need for solving related global problems. In order to achieve a balance between environmental issues and development, the concept of sustainable development continues to direct international cooperation, especially within the UN system. The main stages of the development of the concept of sustainable development are summarized and systematized in Fig. 3.1.

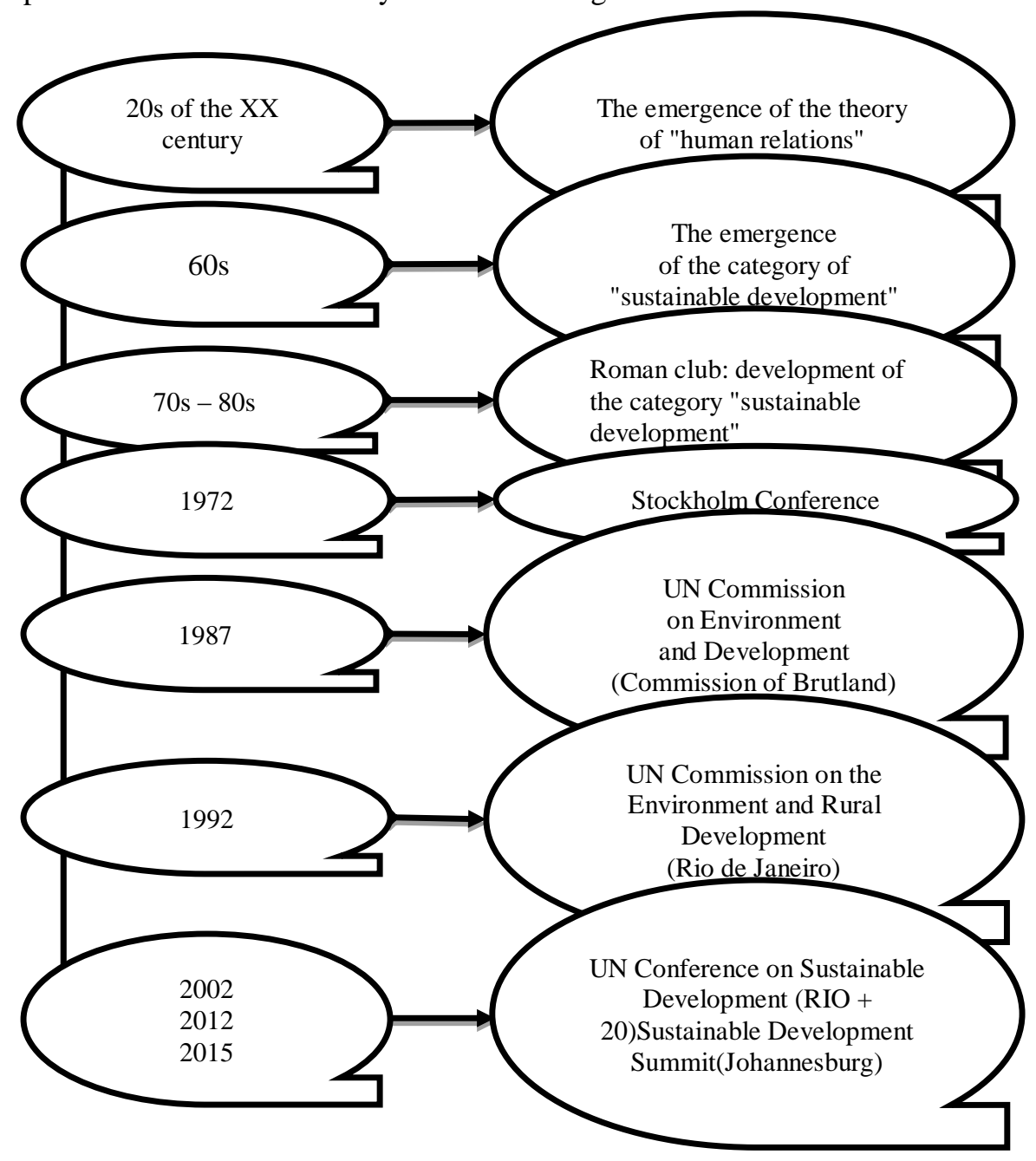

Figure 3.1. The main stages of the formation of the theory of sustainable development Source: compiled by the authors on the basis of UN Documents Sustainable Development

Exhaustive resources include fossil fuels, metals and phosphorus. These substances are extracted from the earth's crust, which are not part of the ecological system and are not renewed. 
The main questions about these resources are: how they should be distributed among people at the present stage of development; how they should be distributed among the next generations. Preserving all resources for future generations will not allow modern generations to meet their needs, but brutal exploitation will mean that future generations risk not meeting their needs. Future generations may have a huge need for oil burned today, and so on.

Capital refers to assets created by people: roads, buildings, factories, etc. Economic stability involves managing this infrastructure. One of the key issues is to choose the right way to invest in infrastructure. For example, one-way investments in the highway affect the ability of future generations to develop new transport solutions. The challenge is to maintain a long-term perspective along with current needs. Economic growth is an indicator that most closely correlates with sustainable development and implies an increase in the total cost of goods and services produced in the country, which is generally referred to as gross domestic product or GDP.

The causes of economic growth can be seen from different sides: on the one hand, the reason may be the expansion of access to labor, capital and other needs, and, on the other hand, increase productivity. That is, economic growth can be achieved by saving and investing, for example, in infrastructure, factories, machinery or education, or by increasing labor, energy, raw materials, natural capital (agricultural land or water), or ecosystem services. Or, by increasing the productivity achieved through the development of technologies, which in turn allows for more efficient production of goods and services, therefore, each unit produced requires lower costs (labor, capital and resources).

An important conclusion is that the link between economic growth and the environment depends on the nature of economic growth, that is, on what stimulates growth. If growth is only due to increased use of limited and renewable resources, as well as increased demand for nature, the provision of ecosystem services will have serious negative environmental impacts. If growth is solely due to increased productivity, growth can even be environmentally beneficial.

The economic dimension of sustainable development is to find an effective way to manage the economy and financial resources and to find a balance between the needs of present generations in relation to the future, which is the main vector of sustainable development. Achievements of the CSR concentrate the country on the modern problems of humanity and help to reduce their impact on the future generation. In the context of population growth and consumption of natural resources, sustainable development is a model of development aimed at balancing economic growth, quality of life and preservation of the environment in the medium and long-term, without increasing the consumption of natural resources that exceeds the potential of the Earth. A distinctive feature of the European model of development is the link between the goal of increasing competitiveness and social and environmental goals, which leads to deeper links between sustainable development and competitiveness.

Since sustainability and competitiveness are interconnected, a broad vision of competitiveness must be clear to both the economy and society.

The European Commission is showing the growing interest in sustainable development, not only in the context of environmental policy, but also in the recent past in the context of all political decisions, whether economic, social or environmental. In this sense, competitiveness is a key issue in the context of a knowledge-based economy. Currently, competitiveness and sustainability have become key words in the discourse on global strategies for prosperity and development. The relationship between these two concepts is widely studied by scientists, policy practitioners and international organizations.

Over the past few decades, interest has grown largely as a result of influential public works; the most popular document is the report "Our Common Future" (Brundtland G., 1987), 
which identified sustained development as «a development that meets the needs of the present without compromising the ability of future generations to meet their own needs». This definition covers several aspects of development that are superior to economic growth in order to include material and non-material needs of life. Although initially the concept focused only on the environmental aspects of development, it also developed in terms of both economic and social dimensions. Thus, the economy has become the dominant problem of human relations with economic growth, determined by the growth of production, as the main priority.

The concept of sustainable development is the result of increased awareness of global links between growing environmental problems, socio-economic problems related to poverty and inequality, as well as concerns about the healthy future of mankind, which is closely linked to environmental and socio-economic issues. When considering the aspects of sustainable development for competitiveness, several approaches should be excluded. So, at the present time, the relationship between the two concepts arises only when it comes to competitiveness from a national or international point of view.

The European Union's socio-economic development strategy for the period up to 2020 draws attention to the fact: EU member states should consider environmental problems as growth opportunities, thus effectively using their natural resources for economic growth. It is known that all sectors of the economy can promote intelligent growth, using new technologies for innovation. In addition, researchers are concerned about the definition of specific future, sustainable competitiveness factors.

One can conclude that globalization, social progress, sustainability, and competitiveness are linked to the different types of competitive advantages that interact and reinforce each other.

The competitiveness of the country is a complex multifaceted concept characterized by the country's achievement of a certain level of development in one or another sphere (economic, social, political, etc.) and the ability to maintain and improve this level. That is, the competitiveness of the country combines all those vectors that set the stage for sustainable development. Because in the period of intensification of globalization, the concept of competitiveness acquires new features, which, to some extent, can be tangled with the achievements of the goal of sustainable development. The country's global competitiveness is due to its place in the world market, the international division of labor, the distribution of factors of production, ensuring the state's ability to compete and the most effective use of competitive advantages over other countries. To assess the level of competitiveness of a particular country at the global level there is a global competitiveness index (Global Competitiveness Index), which depends on rational use of the country's own resources. It was created within the framework of the World Economic Forum in 2004. With the help of the Global Competitiveness Index, one can assess the ability of countries to ensure a high level of well-being of the population and the ability to maintain market relations at an appropriate level and strives for sustainable development. Therefore, it would be advisable to analyze which index of sustainable development is observed in the most competitive countries by the index of global competitiveness.

By adopting the Agenda for Sustainable Development, world leaders have decided to liberate humanity from poverty, provide a healthy planet for future generations, and build peaceful, inclusive societies as a foundation for a decent life for all. After all, only under such conditions, each of the countries will be competitive in the modern global market. The «Agenda» by 2030 is ambitious and transformational, with 17 integrated and indivisible goals of sustainable development, which should be development vectors. It is important that this is a universal agenda that applies to all countries; even the richest and most developed economies have yet to fully secure the rights of women, eliminate inequality or protect the 
environment.The country's annual reports and general reports from various international organizations show that the pace of progress in many areas is much lower than what is needed to achieve the goals by 2030.In order to raise the standard of living of 767 million people still living for less than 1.90 US. dol. per day, and to provide food security for the 793 million people who regularly fight hunger, targeted action is needed. The governments of the countries should double the pace of combating the high mortality rate of mothers. The world needs faster and more productive progress towards achieving sustainable energy and increasing investment in sustainable infrastructure. Qualitative education should be accessible to all without exception; if by 2030 all children in low-income countries had graduated from high school, by 2050, per capita income would increase by $75 \%$ (according data fromUN official website) which would lower world poverty rates and increase the competitiveness of developing countries. More than 2 billion people live in countries with a lack of freshwater. Nine out of 10 urban residents live in cities where air pollution is a health hazard. Planetary warming remains unchanged, setting a new record of about 1,1 degrees Celsius above pre-industrial period and contributing to an increase in the frequency of extreme weather events. The 2030 program for sustainable development is aimed at improving the lives and future prospects of everyone, everywhere. Indeed, sustainable and inclusive development is the very goal and the best form of competitive functioning of every country in the world. Table 3.1 shows that nearly 20 of the most competitive countries in the world include almost all the same countries, which rank as leaders in the index of sustainable development.

Table 3.1. The positions of the countries of the world on indicators of the index of sustainable development and the index of global competitiveness, 2015

\begin{tabular}{|l|c|c|c|c|}
\hline \multirow{2}{*}{ Country } & \multicolumn{2}{|c|}{ Global Competitiveness Index } & \multicolumn{2}{c|}{ Sustainable Development Index } \\
\cline { 2 - 5 } & Place & Index & Place & Index \\
\hline Switzerland & 1 & 5,7 & 1 & 2,922 \\
\hline Singapore & 2 & 5,65 & 20 & 2,59 \\
\hline USA & 3 & 5,54 & 14 & 2,754 \\
\hline Finland & 4 & 5,5 & 6 & 2,892 \\
\hline Germany & 5 & 5,49 & 11 & 2,801 \\
\hline Japan & 6 & 5,47 & 16 & 2,719 \\
\hline Hong Kong & 7 & 5,46 & 81 & 1,763 \\
\hline Netherlands & 8 & 5,45 & 12 & 2,795 \\
\hline UK & 9 & 5,41 & 15 & 2,747 \\
\hline Sweden & 10 & 5,41 & 2 & 2,916 \\
\hline Norway & 11 & 5,35 & 4 & 2,903 \\
\hline Arab Emirates & 12 & 5,33 & 35 & 2,41 \\
\hline Denmark & 13 & 5,29 & 10 & 2,818 \\
\hline Taiwan & 14 & 5,25 & 81 & 1,763 \\
\hline Canada & 15 & 5,24 & 9 & 2,83 \\
\hline Qatar & 16 & 5,24 & 42 & 2,281 \\
\hline New Zealand & 17 & 5,2 & 7 & 2,884 \\
\hline Belgium & 18 & 5,218 & 18 & 2,686 \\
\hline Luxembourg & 19 & 5,17 & 8 & 2,852 \\
\hline Malaysia & 20 & 5,16 & 43 & 2,276 \\
\hline
\end{tabular}

Source: compiled by the authors on the basis of data retried from: http://reports.weforum.org/global-competitiveness-report-2014-2015/rankings; http://wdc.org.ua/en/services/country-profiles-visualization 
The maximum rating scores in both positions are: Switzerland (GCI = 5.7; SDI = 2.92), Finland $(\mathrm{GCI}=5.5$; SDI $=2.89)$, Germany $(\mathrm{GCI}=5.49$; SDI = 2; 8), Sweden $(\mathrm{GCI}=5.41$; $\mathrm{SDI}=2.92)$, Norway $(\mathrm{GCI}=5.35$; $\mathrm{SDI}=2.9)$. High indicators are due to the presence of the vector on sustainable development as a direction of policy of states and the main operating strategy. Including, in addition to focusing on the high development of the national economy in these countries, developed social and environmental spheres that are part of the objectives of sustainable development. That is, the achievement of sustainable development leads the country to a new leading position in the world market and strengthens its competitiveness in all its branches, because sustainable development is all-pervading.

Equally important is the comparison of the top 20 countries of the world with the index of sustainable development and the global competitiveness index (Table 3.2).

Table3.2. World currencies in terms of SDG index and Global Competitiveness Index, 2017

\begin{tabular}{|c|c|c|c|c|}
\hline \multirow[t]{2}{*}{ Country } & \multicolumn{2}{|c|}{$\begin{array}{l}\text { Global Competitiveness } \\
\text { Index }\end{array}$} & \multicolumn{2}{|c|}{$\begin{array}{c}\text { SDG Index: Progress on Sustainable } \\
\text { Development Goals }\end{array}$} \\
\hline & Place & Index & Place & Index \\
\hline Switzerland & 1 & 5.9 & 1 & 85,6 \\
\hline United States & 2 & 5.9 & 42 & 72,4 \\
\hline Singapore & 3 & 5.7 & 61 & 69,0 \\
\hline Netherlands & 4 & 5.7 & 14 & 79,9 \\
\hline Germany & 5 & 5.7 & 6 & 81,7 \\
\hline Hong Kong & 6 & 5.5 & - & - \\
\hline Sweden & 7 & 5.5 & 8 & 81,2 \\
\hline UK & 8 & 5.5 & 16 & 78,3 \\
\hline Japan & 9 & 5.5 & 11 & 80,2 \\
\hline Finland & 10 & 5.5 & 3 & 84,0 \\
\hline Norway & 11 & 5.4 & 4 & 83,9 \\
\hline Denmark & 12 & 5.4 & 2 & 84,2 \\
\hline New Zealand & 13 & 5.4 & 20 & 77,6 \\
\hline Canada & 14 & 5.3 & 17 & 78,6 \\
\hline Taiwan & 15 & 5.3 & - & - \\
\hline Israel & 16 & 5.3 & 52 & 70,1 \\
\hline United Arab Emirates & 17 & 5.3 & 77 & 66,0 \\
\hline Austria & 18 & 5.2 & 7 & 81,4 \\
\hline Luxembourg & 19 & 5.2 & 33 & 75,0 \\
\hline Belgium & 20 & 5.2 & 12 & 80,0 \\
\hline
\end{tabular}

Source: compiled by the authors on the basis of data retried from: https://www.weforum.org/reports/the-global-competitiveness-report-2017-2018; http://www.openshkola.org/blog/sdg-index-indeks-progressa-po-tselyam ustojchivogorazvitiya/

Index SDG (Index of Sustainable Development Goals) - Bertelsmann Stiftung and the UN Sustainable Development Solutions Network (SDSN) experts for the first time in 2015 for a small number of countries, and in 2017 for the majority, plan to help countries launch their sustainable development activities and offer them a platform to compare their efforts with the region's efforts, countries at different levels of economic development and with the progress of the world in the goal. The index helps each country set its priorities, understand the main difficulties and identify gaps in the work on sustainable development. The index 
includes 77 indicators (economic, social, environmental and other indicators), the values of which are calculated from the worst to the best and combined into a final score of 1 to 100 points. The authors note that the methodology for calculating the SDG Index has not yet been worked out to the end, as in some countries there is no important information without which it is not possible to properly assess progress.

The countries that scored the maximum positive rating in both categories include Switzerland, the Netherlands, Germany, Japan, Sweden, Finland and Denmark. The study shows that without the country's orientation on the bases of sustainable development of global competitiveness it is impossible.So, again, up to 20 of the leaders in both countries include almost the same countries, which again demonstrate that the vector's direction of the state for sustainable development and the achievement of the goals of sustainable development is one of the key conditions for the competitiveness of the countries of the world.

Despite the growing interest in sustainable development, the relationship between environmental, social sustainability and competitiveness was only insignificant. So far, economists have devoted their efforts to trying to understand how economic growth affects the quality of the environment or the distribution of income in the country and vice versa. However, little is known about how these aspects of sustainable development relate to competitiveness. There fore, the study of these aspects is multifactorial and complex, the points of contact between competitiveness and the achievement of the goals of sustainable development are to some extent evident and demonstrated above.

The global competitiveness of the national economy is due to its place in the global economic complex. Competitiveness combines the country's position in the social, economic, political and environmental spheres. Among the large number of ways, one of the most important directions of increasing the competitive positions of the social and economic categories of the country is to overcome gender inequality, as was analyzed above.

One of the obstacles to eliminating gender-based discriminatory practices is the lack of legal guarantees in the countries of gender equality of rights and opportunities in all spheres of state functioning. International experience points to the positive effect of adopting specialized laws for the purpose of establishing a gender balance (for example, the law on equal pay for women and men for the same work done, as Iceland did).

One of the mechanisms at the legislative level is the establishment of a gender quota in one or another structure. Many states apply quotas to ensure women's representation in power structures. In the area of quotas policy, it is extremely important for all states without exception, because the small number of women in parliaments, and in general in the political sphere, according to the gender gap index, is the biggest problem. It could also be the creation of parliamentary groups or commissions of equal rights and opportunities. In order to achieve gender parity and monitor the level of this issue, it is necessary to create social online platforms and support services, because sometimes women are afraid to speak openly about discriminatory manifestations against themselves. A very important step towards overcoming gender imbalances is the creation of social institutions that should help women combat unfavorable economic situations in order to maintain an adequate standard of living. States should create conditions conducive to combining the professional and family functions of both men and women.

Overcoming gender gaps by attracting more people will also affect the pace of economic growth and the achievement of decent working conditions for the population. What is the second direction of increasing the competitiveness of the country, as well as economic growth can be only due to the inclusion in the process of managing all the components of the country on an equal footing. In Ukraine, the vector of economic growth is scattered to solve many 
local problems: the shadow economy, the reduction of investment in the country due to political instability, poor working conditions and low wages for most of the population and the differentiation of regional development.

Economic growth and decent working conditions can be achieved at the expense of a coherent development policy: the development of a legislative and regulatory framework regulating the transition from a sectoral to a regional system for managing economic development; restructuring of the public administration system by economic development in the regional rather than branch-based manner; the creation of a coordinating state body that controls interregional cooperation for the effective balanced development of the country as a whole and the avoidance of disputed problems between the regions; development of a ecological and economic development of regions state program; restructuring of the state statistical system accounting by sectoral principles; developing a mechanism for providing subventions and other forms of financial support to environmentally-integrated regions, taking into account the principle of national interests priority; development of the mechanism of enterprises responsibility for the inappropriate use of natural resources and unjustified burden on the ecosystem with the introduction of appropriate changes to the economic and criminal codes.

Concerning measures for implementing the concept of sustainable development at the regional level, it is: creation of local bodies of state supervision of the operation of enterprises and observance of the ecologically oriented principles of using natural resources and exploitation of ecosystems; Develop, in cooperation with scientific institutions, criteria for assessing compliance by enterprises with the conditions and principles for the balanced use of resources; the introduction of a system of fines and other sanctions (Fig. 3.2).

\section{Creation of balanced model for ecological and economic development of the region}

Increasing the competitiveness of the region by improving the investment and innovation climate
State policy that will ensure a harmonious combination of national and regional interests, taking into account the trends of world development
Priority measures and directions of regional policy development

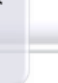


natural resources; additional funds to local budgets (in the form of fees for the use of natural resources and fines for violation of the conditions of ex-operation of ecosystems).

However, in order to achieve this effect, a mechanism for the interaction of components that determine such efficiency should be developed. It consists of several points that are inextricably linked: the economic and legal mechanism of state regulation in the sphere of balanced use of natural resources, organizational and economic mechanism of transition of enterprises to the principles of balanced development, organizational and economic mechanism of regional and interregional interaction, economic mechanism of financial provision of investment activity in this sphere, economic-ecological mechanism of rational use of natural resources of the region.

Summarizing the above, it should be clearly stated that the priorities of national sustainable development strategies should lie in the reorganization of the national economy system in accordance with the principles of the ecologically balanced territorial approach, which will enable to take into account the interests of all participants, to transfer part of the environmental load from the most economically weak entities, to create effective a mechanism for redistribution of financial resources within the territories and regions, to restore the state of the ecological balance of the most problematic territories to develop a clear system of reaction in the development of certain regions (or their individual objects), to eliminate disproportions in the development of countries and to stimulate economic potential.

The development of the country and the transition to the concept of sustainable development should be gradual, passing each stage thoroughly and qualitatively (Fig. 3.3).

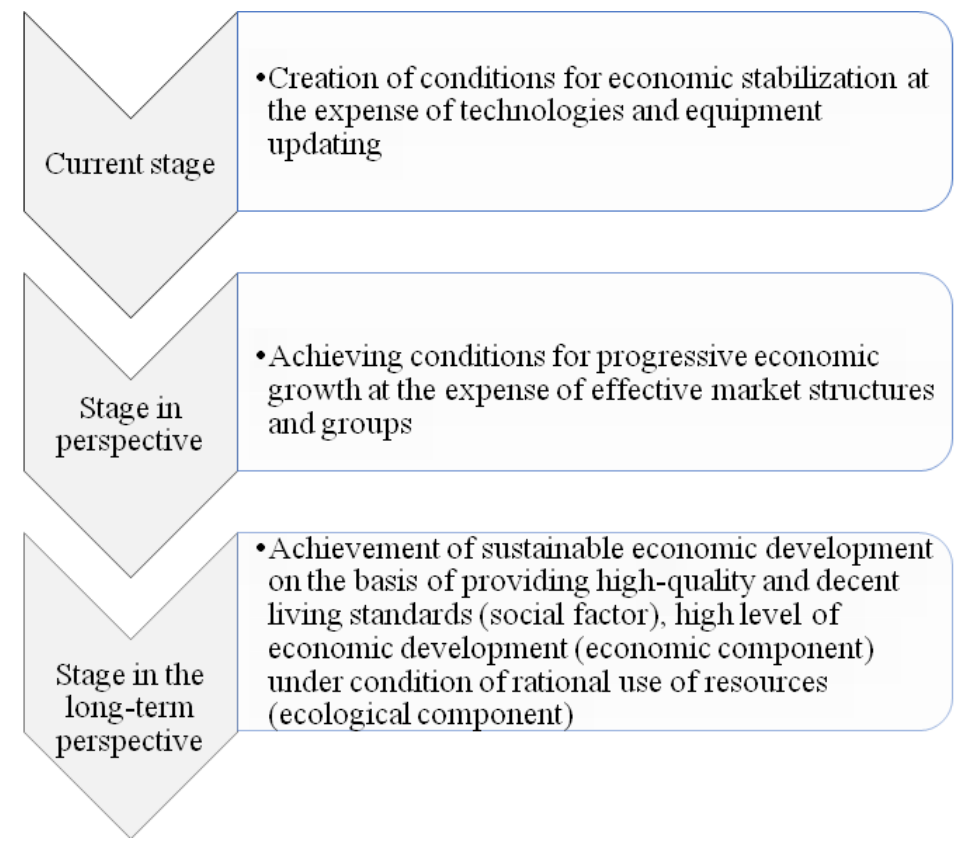

Figure 3.3. Stages of achieving sustainable development of the national economy Source: developed by the authors

Consequently, the achievement of sustainable development should be carried out in three stages (Fig. 3.3): 1) the current stage, namely the creation of conditions for economic stabilization on the basis of innovation renewal; 2) phase in perspective (transitional), namely: 
effective market structures are one of the main conditions for a stable economic growth and increase of living standards; this process in Ukraine is slow, because it is hampered by economic, institutional and social obstacles; 3) a long-term perspective stage, namely the achievement of sustainable comprehensive development, which will bring new vectors of competitive development to the country.

\title{
References
}

Brundtland G. (1987). Our common future. Oksford: Oksford: University Press.

Europe 2020 strategy. Avaliable at: http://www.cbss.org/wp-content/uploads/2012/12/Europe2020-Strategy.pdf

Meadows, D. H., Meadows, D. L., Randers, J., Behrens III, W. W. (1972). The Limits to Growth: a report for the Club of Rome's project on the predicament of mankind. NY: Universe Books.

Paton, B.Ye. (2012). National paradigm of sustainable development of Ukraine. Kyiv: DU IEPSR.

SDG Index. Avaliable at: http://www.openshkola.org/blog/sdg-index-indeks-progressa-potselyam ustojchivogo-razvitiyal

The Global Competitiveness Report 2014-2015 Avaliable at: http://reports.weforum.org/globalcompetitiveness-report-2014-2015/rankings

The Global Competitiveness Report 2017-2018. Avaliable at: https://www.weforum.org/reports/the-global-competitiveness-report-2017-2018

The Millennium Development Goals. Avaliable at: http://www.undp.org/content/undp/en/home/mdgoverview.

The official website of the United Nations Organizations. Avaliable at: https://www.un.org/sustainabledevelopment/sustainable-development-goals/

The official website World Data Center for Geoinformatics and Sustainable Development.Global Analysis of Quality and Life Safety.Avaliable at: http://wdc.org.ualen/services/country-profiles-visualization

UN Documents : Sustainable Development. Avaliable at http://www.un-documents.net/k001303.htm

United Nations Sustainable Development Knowledge Platform. Avaliable at: http://sustainabledevelopment.un.org.

\subsection{LOCAL COMMUNITY SAFETY AND GLOBAL SECURITY POLICY}

\author{
Valentina Kunchenko-Harchenko \\ Doctor of Technical Sciences, Professor, \\ Head of the Informatic, Information Security and Documental Sciences Department, \\ Cherkasy State Technological University, Cherkasy, Ukraine
}

Globalization is a very broad and complex process which has the influence on all spheres of life, i.e. higher level of advanced process of business activity internationalization. The term "globalization" is quite often used in various fields. It can be found for example in economic, political and social lexicons and not only there. It occurs also in the mass media, in the environments of businessmen, economists and politicians. It more and more often appears 
in both school and academic textbooks and even becomes the basis of new subjects taught in higher education. The term is usually associated with technological development, international integration, the exchange of cultural values or more commonly refers to the Internet. There are different definitions of the word; however, they have common elements. Referring to the issues mentioned above, it is said that globalization is a catch-all term which catches every possible aspect of the processes that take place in the modern world (Wosinska, W., 2008). The definition of globalization according to The PWN Encyclopaedia (1964) is the following: "globalization, characteristic and dominating trends at the end of the 20th and beginning of the 21 st century in the world economics, politics, demographics, social life and culture depending upon the spread of similar phenomena, regardless of geographical context and the level of economy development of the particular region; globalization leads to the unification of the world's image as a homogeneous entirety of interrelated economic elements and common consumption culture". Another example of the definition, given by (Cziomer, E., 2000) is: "Globalization is the process which occurs in the world economy and is characterized by intensification, mobilization and flow of goods, capitals and labour force in a worldwide scale, the development of transport, communication, telecommunication and the fast flow of information in the media. This economic evolution is accompanied by transformations in social, cultural, political, constitutional fields leading to confrontation and approximation in this respect between states, nations and people all over the world. Globalization has thus its economic, social, political and cultural dimension".

Undoubtedly, on the basis of various definitions it can be said that globalization is a complex process and even a set of processes which have the influence on our lives. This is multi-faceted notion, because it is connected with various fields. The processes of globalization have a huge scope, because they concern the whole globe. Events, decisions and actions of this process, even if they occur in one part of the world, influence the remaining, and even a single society or individual people. The term has at least three meanings: it specifies new trends in culture, is a new phase of the development and modernization of international relations and refers to international social relations. Globalization can be understood as opportunities for the development, the world benefits or threats. Like all other processes it also has its two sides - advantages and disadvantages. The main factor that affects the process of globalization is the development in any field, e.g. technological, communication, social, economic and political integration. The essence of globalization lies in the fact that it existed, exists and will exist, because the world has always been developing for ages and will develop because of the fact that such is the human nature.

Glocalization is the effect of globalization, which has occurred as a result of the tension between localization and globalization. Niedziolka, M. (2011) noted that the word "glocalization" is a combination of two notions: globalization and localization. It pays our attention to the importance and place of local action in globalization process, and the meaning and place of global processes of local development strategies. There are thus two distinct, but interdependent planes of perception and research on glocalization. The first one refers to causes and consequences of the location of companies in particular territory. The second one indicates the conditions for opening particular territory and its integration with the rest of the world, and also specifies the features of the policy for attracting external investments which favour local development". Globalization does not eliminate local issues, but there often is a clash of the one dimension of social life with the second.

The concept of glocalization (Niedziolka, M., 2011) does not include the clash, but it refers to the adjustment of globalization (e.g. certain products) to local conditions on the one side, and local interpretation of global trends on the other side. This concept supposes a 
certain openness of people to the things which come from other places, and the same time, does not require from them to forget their own places". This can be noticed on the example of popular fast food restaurant McDonald's. The place is known around the world, but only in Poland you can buy a sandwich called WieśMac. This is the adjustment to the location. While speaking about the idea of glocalization, economic issues should be discussed as well. In this context, this idea is micromarketing, the adjustment or suitable recommendation of products and services. The intended effect is the will to increase sales and to place particular product in particular place so that the product is desirable. Glocalization within economic scope uses an adverse way of the flow of information, i.e. from localization to globalization. Aiming at this, marketing efforts promote local products, e.g. on the basis of their tradition in order to be offered on the global market (Czerny, M., Łuczak, R. and Makowski, J., 2007).

While considering globalization, it is worth to mention the notion of global village which can be often encountered. This is the concept that consists of two opposing words. On the one hand, global is the word which refers to huge and world-wide, on the other hand, a village is characterized by small space. The expression global village was introduced for the first time by H. M. McLuhan in 1964. It was connected with the development of modern means of mass media, fast information flow and communication. Thanks to these, the world began to change, the life of isolated societies has changed. As in a village, people began to know more about each other (Smolski, R., Smolski, M. and Stadtmuller, E. H., 1999).

Security is the basic need of human existence. It has a lot of different definitions similarly to the term "globalization". But, without any doubts, it is essential for human life. The need for the sense of security is rooted in a human being from the very beginning of his existence. Thanks to it, the man is able to fulfil his other needs and aims. Maslow's pyramid illustrates it in the best way. According to the pyramid, the need for security is in the second place just after physiological needs such as food, water, oxygen, sexual needs, the lack of tension and sleep. Definitions of security can be found in the literature. Security refers to various fields of life similarly as already described globalization. It is an integral need of a man. Each of us knows what this word means, what security is for us, but creating the definition of security causes embarrassment. In the literature of social sciences, in the most general meaning safety covers fulfilling such needs as: the lack of threats, survival, peace, independence, ownership and certainty to unimpeded development. National Defence Academy Dictionary defines security as a state which gives us a sense of confidence as well as a guarantee to keep it and a chance to improve it. Regardless of the number of existing definitions, they have certain common features which reflect safety. Undoubtedly, it is a subjective feeling of a man. Subjective, because each of us fulfils the need for security in a different way. In the age of globalization, many dangers await the man. Actually, it does not only refer to the man as the individual, but also as a group of people, the state, economy, politics, labour market, etc. In each category the need for security must be fulfilled, and in the world there are a lot of different changes thanks to globalization. Each change is associated with some risk. It happens that these changes benefit one country, but for the other one they mean loss. The loss causes anxiety and this in turn is the opposite of security. Because of the fact that there sometimes are plenty of these changes and they quickly progress, the problem increases. Therefore, it is important to introduce changes gradually. The man, however, often admires fast progress and wants to spread a particular issue to the whole world. Unfortunately, nothing is perfect and sometimes you may find that it is a failure rather than a success. People are usually pleased with technological progress and the wool is pulled over people's eyes because of technological innovations. Better and better computers, mobile phones, televisions, common access to the Internet - all these seem to be needed very much. 
Thanks to the man, the world looks today as it is. The man as a rational creature began to transform everything which is possible. Today, the world is significantly different from the one which was 20 or even 10 years ago. You could even take a chance and say that every day something is changing, something comes into being, something is new and the other thing is getting to be old, useless or unnecessary. We aspire to be modern. This concerns each field. It should not be understood that being modern means just following the fashion both in the sense of dressing up in a fashionable style or having trendy house. Nowadays, modernity means more than just the fashionable style of bodily sphere. Modernity is usually manifested practically in all, both spiritual and bodily issues in our lives. Today, this means that we try to follow trendy lifestyle, extolling the style, eating modern meals, the country wants to lead modern policy, education of children is changing all the time as well as medicine, law, religion, etc. In fact, it refers to everything. However, the modernity is not always good, because new does not always mean better, the thing which seems to be new does not always mean really new. Sometimes a particular thing is simply changed, 'improved' but created on the basis of old and strong foundation which has been proved over the years. And sometimes a new thing is not really new for all of us, because the world is diverse in terms of the development. And although globalization tends to unify the world, it will never refer to economic sphere. As far as economy is concerned, countries will always differ between each other in this field. Unifying is seen in other fields and this is a negative phenomenon, though some people can see it as a positive one. This chapter will draw our attention to this issue, i.e. what is seen as positive although it is really negative, what is itself negative and the article will focus also on the problem how all these issues are manifested in our lives and how they influence us.

Aspiring to unify the world is manifested in cultural aspect. Unfortunately, we agree on it, and what is more, it seems to us that this is a positive phenomenon. The loss of national identity or mcdonalization (Ritzer, G., 1999) of the world are commonly discussed issues at present. This is nothing more than creating a monoculture. This is destroying the diversity of cultures. The need for identity is very important for the human. "Thanks to the hard work of biologists, zoologists and ethologists done within more than the past 50 years, today we know that almost all animal species (including man) have three main psychological needs of congenital, and instinctive bases and naturally aspire to satisfy them. These three needs are: the need for identity, security and stimulation. Just as the opposite of safety is the fear and the stimulation is boredom, so the opposite of identity is anonymity. We and the entire nature with us hate anonymity, boredom and fear. We also know now that the need for identity is the strongest one. In the name of identity we are able to sacrifice the other issues. There is no identity without personality. You can even take a risk and state that the need for identity is the religious or quasi-religious need.

Increasingly, more and more people in the world wear similarly, lead a similar lifestyle, watch the same films, listen to the same music and have similar idols. What is more, in the shops we can find identical or even the same products and visit a foreign restaurant without leaving our city. All these cause that cultural differences between people disappear. If you do not look at this phenomenon deeper, you can say that there is nothing wrong with it, and it is quite positive. We have a lot of benefits. But at present, it is hard to meet with friends or family. A modern family is practically associated with foreign people, because they rarely talk to each other, practically do not spend their free time together. When they come back home from work or school every person escapes to his room, where he usually spends his time in front of the TV or computer. New technologies have taken over our lives. A mobile phone, computer, tablet, the Internet, digital television have caused that a man isolates from 
the people who are around him. Some people even claim that it brings people closer, however it is not true. Formerly, people were able to meet with each other, had time for each other and sent greeting cards for Christmas. Today, nobody has time for meetings, even if they meet they just see a film and cannot talk to each other. Sending postcards is nowadays unfashionable, because you can send an email or text message faster. In fact, most of the time we spend in the virtual world. The man opens to everything there. It seems to him that he is indestructible which is caused by the fact that he can be who he wants. Therefore, another problem occurs which refers to the lack of authority of parents for children and young people. Their behavior is getting worse and worse - they have no respect for the elderly and a lot of aggression is characteristic of them as well. Friends are replaced with the computer. These are the Internet, computer games and television which are the sources of their authorities. There, they can find their ideal which can fly, kill or amuse. Unfortunately, the computer takes the reality and absorbs in the virtual world. The computer also replaces traditional game on the field, going out to the cinema or meetings in the backyard. Such situation is worrying. The more so because apart from to clash of the virtual and the real world, there are a lot of threats which wait for them on the Internet. More and more often people make friends via the Internet, but we never know who really sits on the other side of the monitor. It is very easy to get fooled. If we give too much information about ourselves or arrange a meeting with the other person we can become a victim. Particularly exposed are young people, because they are naïve.

Piekarski, R., Graban, M. (2003) noted that the identity of the man consists of two basic elements: the identification with the territory (country, particular area) and the identification with the population, to which he belongs (family, clan, tribe or nation). We do not identify with the issues which occur outside, with foreign and unknown, at least at emotional level. The identity is always distinguishable and evaluative in its nature, therefore in some way it is also discriminatory. The identity which is not discriminatory, distinguishable and evaluative, i.e. global identity is a contradiction itself. So you cannot claim that in globalized world the man feels safe. It is just the opposite. Creating the monoculture has caused that people trust each other less than it used to be in the past. At one time, people passing on the street were nice for each other, today there are few people who say 'good morning' to their neighbour. The man is terribly afraid of strangers. Each of us protects his car, house, flat or mobile phone. At present, people usually have a few different keys to open the door of their house or flat. And it does not only belong to bodily sphere, but also to our sense of security in psychological sense. A person who assumes unnatural habits, customs, speaking style or style of getting dressed is definitely not self-confident. He does not have the sense of himself, the sense of the real and own personality. In order to feel safe internally, the personality and identity must be stable and harmonious. In addition, the sense of balance is essential as well. All these three factors are affected by the impact of external factors, and in globalized world there are many such factors. In shaping our personality, identity and security everything what happens around us has a significant influence, e.g. the way how our peers wehave, the situation at home we have, where and who we work with, etc. The state as one of the main subjects of this process had an impact on the process of globalization shaping. However, with the development of this process and changing forces as well as economic mechanisms, the functioning of the state is changing. There is a need for adjustments in its activity both national and world economy. Due to the increase in costs and threats of globalization, the importance of the state and its activity whose main aim is eliminating unbeneficial effects of the process is increasing. The process of globalization brings far-reaching consequences in all fields of life: in the economy, social life, politics and 
culture. In the field of social and economic aspects, there are changes in the structure and way of functioning of market economy, the structure of production and employment, the form and scale of business, forms and structures of the production and employment, forms and scales of enterprises, forms and structures of economy management, social division of the income and the role and way of functioning of state organisms.

\section{References}

Bauman, Z. (2000) Globalization. Warsaw: National Publishing Institute.

Czerny, E. (2004) Globalization from A to Z. Warsaw: National Bank of Poland.

Czerny, M., Luczak, R., Makowski, J. (2007) Globalistics.Global process and their local consequences. Warsaw: PWN.

Cziomer, E., (2000). Globalization and international relations.Europie, vol. 3,114.

Furdala, A., Wysoczański, W. (2006). Migration : history, types and definitions. Wroclaw: Wroclaw Universuty.

Liberska, B. (2002). Globalization.Mechanism and challenges. Warsaw: Poland Economic Publishing House.

Misiak, W. (2009). Globalization: textbook. Warsaw: Difin SA.

Niedzyolka, M. (2011)Globalization and glocalization. Warsaw:Difin SA.

Okoń-Horodynska, E. (2003). Problems and controversies around globalization.KatowiceEconimic Academy PH.

Piekarski, R., Graban, M. (2003) Globalization and we. Krakow: Universitas.

Ritzer, G. (1999). McDonalization of society. Warsaw: PublisherMuza.

Sadowski, Z. (2002) The role of countries at the globalization epoque. Warsaw: Poland Economic Publishing House.

Wielka encyklopedia powszechna PWN (1964), vol. 4. Warszawa: PWN.

Wosinska, W. (2008). Face of globalization. Sopot: Smak Slowa. 


\title{
CHAPTER 4
}

\section{GLOBAL PARTNERSHIP IN ACTION: IMPLEMENTATION OF INTERNATIONAL PROJECTS IN UKRAINE}

\subsection{FEATURES OF INTERREGIONAL INTERACTION IN THE CONTEXT OF IMPLEMENTATION OF INTERNATIONAL PROJECTS}

\author{
Olena Kolomytseva \\ Doctor of Economics Sciencies, Professor, \\ Head of the Economic Cybernetics and Marketing Department, \\ Cherkasy State Technological University, Cherkasy, Ukraine \\ Yuliia Kulyk \\ Lecturer of the Economic Cybernetics and Marketing Department, \\ Cherkasy State Technological University, Cherkasy, Ukraine
}

In the current conditions of globalization and integration processes development, regions of Ukraine take an active part in the international activities. Intensification of international cooperation in various fields, such as social, environmental, administrative, and economic is typical nowadays. The nature and content of integration processes in the world potentially builds relations of strategic partnership and alliance, which allows for the formation of new partnerships of regional interaction.

Each region of Ukraine has unique features which are characterized by different levels of use of regional potential - regional features of the use of resources, leveling of economic and political complexities in Ukraine, maximization of opportunities for further development. Such unique features of the regional potential form competitive advantages in the international space.

Thanks to financial and technical assistance from the neighboring states of the EU a number of long-term projects and other measures of international importance in the field of development of interregional cooperation are implemented in the regions of Ukraine. The further development of interregional cooperation is relevant and corresponds to the main trends of the development of regional policy of Ukraine and directly corresponds to State Strategy for Regional Development until 2020 (Decree of the Cabinet of Ministers of Ukraine, 2014).

Interregional cooperation is an extremely important area of regional policy, which ensures a progressive and balanced socio-economic development of regions based on the establishment of long-term, equal and mutually beneficial relations among them. The ignificance of interregional cooperation for the development of the regions of Ukraine in the current conditions is determined by the fact that it allows to strengthen the economic ties of the regions, optimize the placement of infrastructure, based on the cooperation of their activities, exclude ineffective financial costs associated with the creation of duplicate economic structures and unjustified interregional competition, unite the economic potential of the regions to solve the most large-scale investment projects and disseminate progressive experience in the fronts of innovative development of the regions of Ukraine.

We agree with Mamonova V. V. (2009) that interregional cooperation should be understood as a complex of exchange of flows of resources, carried out in the framework of interaction among authorities, legal entities and individuals of different regions with the aim 
of representing common interests in the world economic space and increasing the level of sustainable development of these regions. Interregional links are interactions of the subjects in various fields (economics, science, culture, etc.). The main forms of interregional interaction are multilateral - with the participation of several actors and bilateral - with the participation of two subjects.

Kish E. B. (2008) noted that interregional cooperation is a powerful tool for solving regional problems. It is an integral part of a well-calculated mechanism of regional development, which has a strategy for implementation. The main tasks of the development of interregional cooperation are:

- development and strengthening of interregional cooperation;

- ensuring sustainable social and economic development of regions through joint development and implementation of relevant projects and programs;

- environmental protection;

- development of regional infrastructure;

- reduction of interregional disproportion between regions.

Regions' participation in international projects and programs enables not only to attract additional foreign capital into the national economy, but also helps to intensify interaction among the regions of Ukraine. Close interregional links and participation in international projects ensure investment attractiveness and successful socio-economic development of the regions and the country as a whole. Attraction of interregional assistance will allow resources allocation according to the priority directions of development of regions of Ukraine. Efficiency and effectiveness of engagement in the international projects and programs, creation of a communication platform among the regions will allow the resources to be used in the most urgent and most important areas as efficiently as possible.

Granberg, A. G. (2006) determined the most important components of interregional cooperation, there are:

- scientific and technical cooperation - exchange of experience, support of specialists and innovators, search and support of innovations;

- trade and economic cooperation - provides consumer market with goods that are not produced in the region, and local producers - with stable supplies of raw materials and components; contributes to stimulating the development of the domestic market of goods and increasing domestic demand for products, diversifying the economy, removing territorial barriers that impede the movement of productive, investment and labor resources between regions;

- cooperation in educational field - admission of students and pupils from different regions, student exchange, advanced training and exchange of experience of university and school teachers from other regions;

- cooperation in cultural field- formation of channels for intercultural communication among regions, preservation and presentation of the achievements of the traditional culture of different peoples on the national scale, preservation and development of Ukrainian language and Ukrainian art traditions;

- youth cooperation - exchange of information and experience of active participation in the development of democratic, economic and social institutions of the regions, in education of younger generation and others;

- cooperation in the field of crime prevention.

The tendency to involve the regions of Ukraine in participation in the international projects and programs during the years 1994-2017 is ambiguous (Fig. 4.1). During 19942006, the number of existing international projects was rather low. The aggravation of crisis 
situations in 2012-2013 has contributed to the increase in international assistance for the regions of Ukraine.

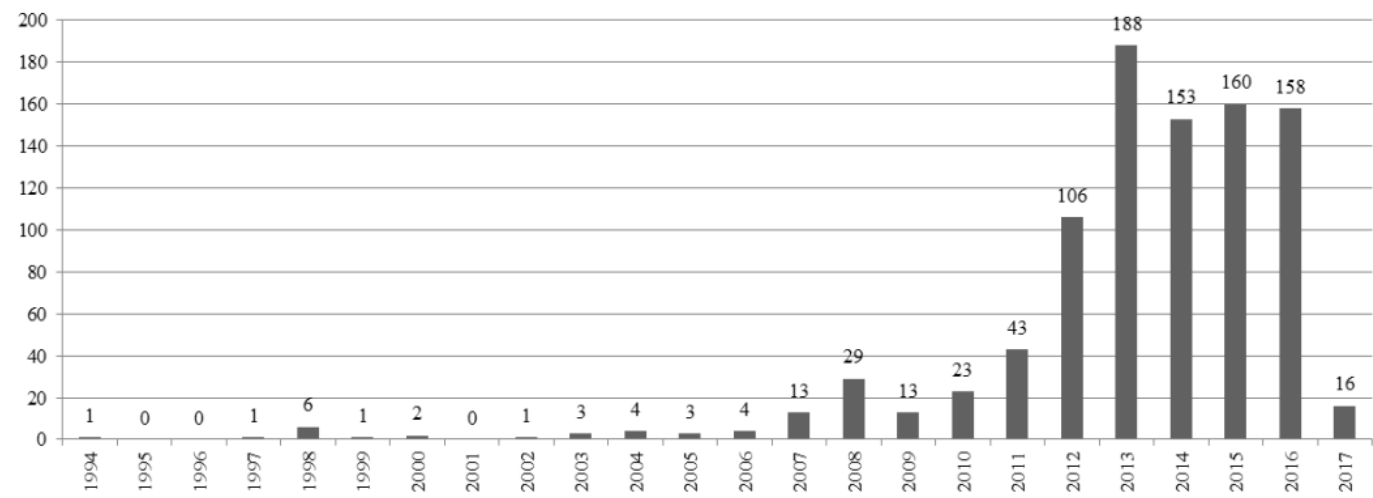

Figure 4.1. Number of international projects and programs implemented in Ukraine, 1994-2017 years

Source: compiled by the authors on the basis of data retried from http://openaid.gov.ua/uk

As of the beginning of 2018, Ukraine has 175 international projects with a total financing of 5,973 mln.USD. Sectoral distribution of the international assistance to the regions of Ukraine has made it possible to analyze the percentage of each industry and shows which sectors are leading in attracting international projects, and which require the intensification of integration processes (Fig. 4.2).

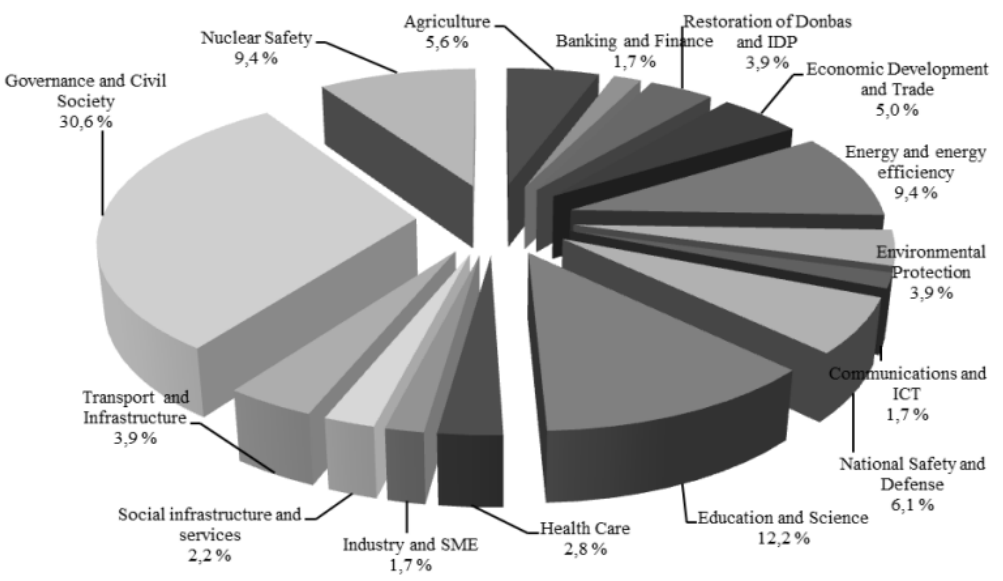

Figure 4.2. Division of existing international projects in terms of activity, 2018 Source: compiled by the authors on the basis of data retried from http://openaid.gov.ua/uk

The main activities that attract international projects to the regions are: government and civil society (55 projects), education and science ( 22 projects), energy and energy efficiency (17 projects) and nuclear safety (17 projects).

The share of the smallest amount of international assistance for the regions of Ukraine includes banking and finance sector (3 projects), communications and information technologies (3 projects), industry and small and medium enterprises (4 projects), social 
infrastructure and health care (5 projects). The main donors of the number of international projects are European Union - 500 projects, U. S. Government - 133 projects, European Bank for Reconstruction and Development (EBRD) - 54 projects and United States Agency for International Development (USAID) - 54 projects (Fig. 4.3).

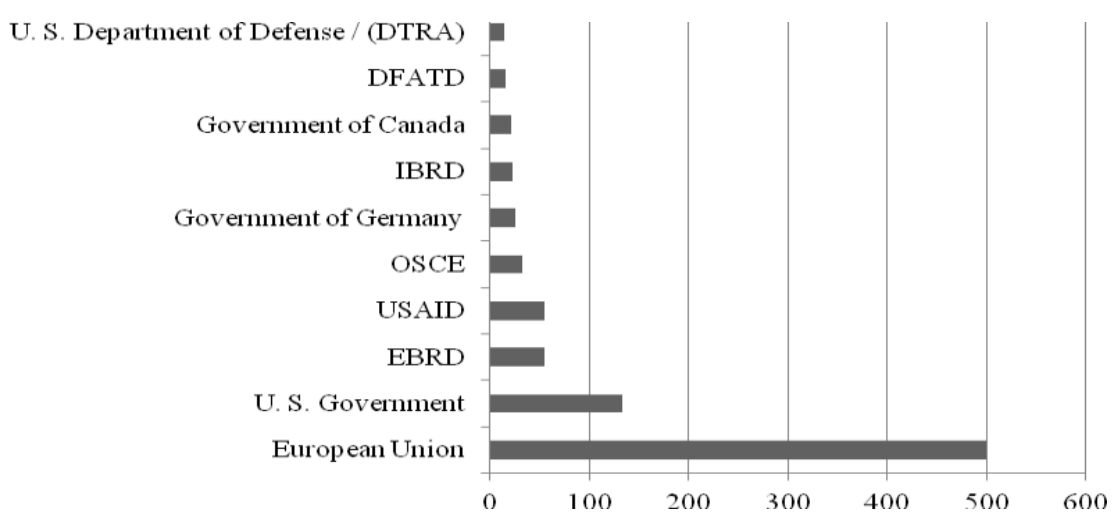

Figure 4.3. Main donors of the regions in terms of international projects

Source: compiled by the authors on the basis of data retried from http://openaid.gov.ua/uk

In the ranking of regions' involvement in the international projects and programs, the leaders are Kyiv, Lviv and Zakarpattya regions. Less active participants in the international projects are: Volyn, Ivano-Frankivsk, Odesa, Dnipropetrovsk, Donetsk and Luhansk regions. All other regions of Ukraine, including the city of Kyiv, are the least active in attracting international projects and programs. The grouping of the regions served as the basis for creating a network model for interregional interaction. Implementation of joint projects allows to establish close interaction among regions (Fig. 4.4).

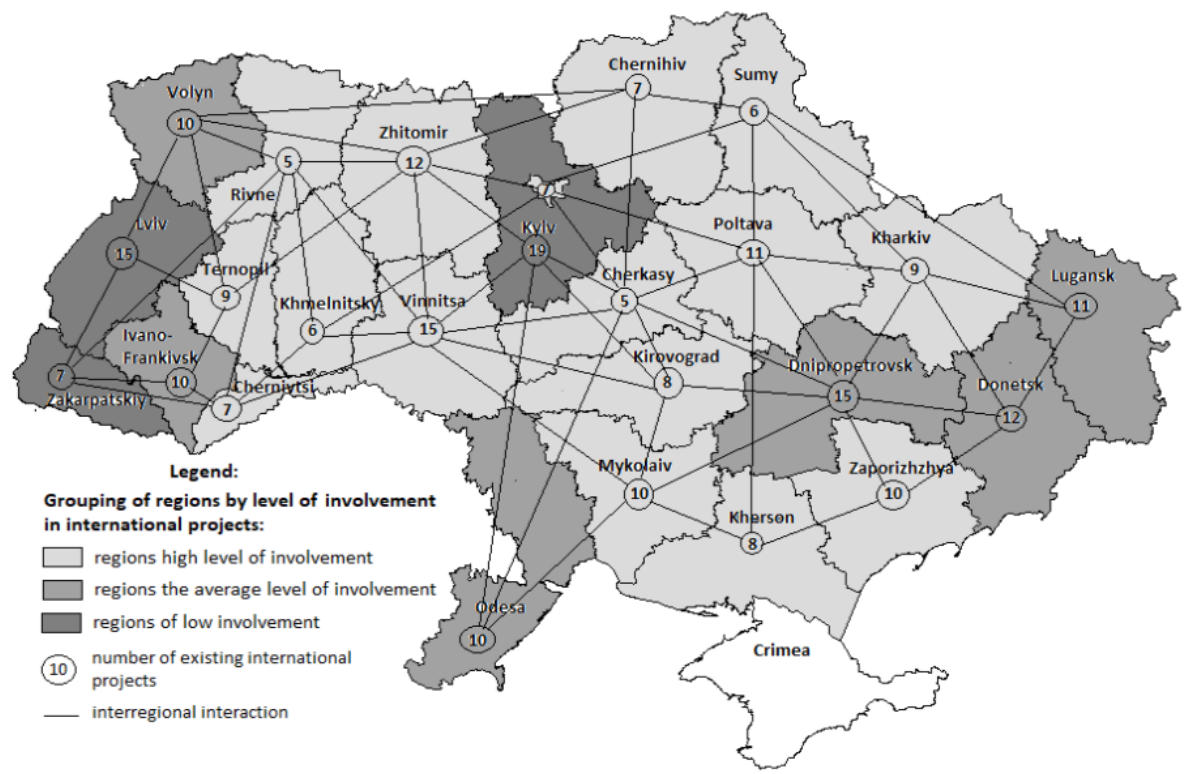

Figure 4.4. Network model of interregional cooperation: international projects

Source: developed by the authors 
As of the beginning of 2018, the most active regions in terms of the number of existing projects are Kyiv (19 projects), Lviv, Vinnitsya and Dnipropetrovsk (15 projects), which comprise about 6-8\% of the total number of the existing projects in Ukraine. Donetsk, Zhytomyr, Lugansk, Poltava, Volyn, Ivano-Frankivsk, Mykolaiv, Zaporizhia and Odessa regions were less active in attracting the international projects. Cherkasy, Rivne, Khmelnytsky and Sumy regions (5-6 active projects) are outsiders in the interaction in international projects. The were 5 existing international projects in Cherkasy region at the beginning of 2018 with a total aid of $884 \mathrm{mln}$.USD, which is $41.7 \%$ of the total number of projects in the region (Table 4.1).

Table 4.1. Description of the international projects in Cherkasy region, state on 01.01.2018

\begin{tabular}{|c|c|c|c|c|}
\hline Name & Period & Budget & Donors & Executors \\
\hline $\begin{array}{l}\text { Safety improvement of } \\
\text { ionized radiation sources } \\
\text { used in Ukraine }\end{array}$ & $\begin{array}{l}2003- \\
2020\end{array}$ & $\begin{array}{l}18000000 \\
\text { USD }\end{array}$ & $\begin{array}{l}\text { U.S. Department of } \\
\text { Energy; } \\
\text { U.S. Government } \\
\end{array}$ & $\begin{array}{c}\text { Pacific Northwest } \\
\text { National Laboratory } \\
\text { (PNNL) }\end{array}$ \\
\hline $\begin{array}{l}\text { Development of the } \\
\text { course for strengthening } \\
\text { of local governments in } \\
\text { Ukraine (PULSE) }\end{array}$ & $\begin{array}{l}2015- \\
2020\end{array}$ & $\begin{array}{l}8200000 \\
\text { USD }\end{array}$ & $\begin{array}{c}\text { U.S. Agency } \\
\text { for International } \\
\text { Development } \\
\text { (USAID); } \\
\text { U.S. Government }\end{array}$ & $\begin{array}{c}\text { Ukrainian Association } \\
\text { of Local Government } \\
\text { Bodies "Association of } \\
\text { cities of Ukraine" }\end{array}$ \\
\hline $\begin{array}{l}\text { Transparent, accountable } \\
\text { and effective budget } \\
\text { process at the local level } \\
\text { in Ukraine }\end{array}$ & $\begin{array}{l}2015- \\
2018\end{array}$ & $\begin{array}{l}1177662.2 \\
4 \text { EUR }\end{array}$ & European Union & $\begin{array}{c}\text { Ukrainian Association } \\
\text { of Local Government } \\
\text { Bodies "Association of } \\
\text { cities of Ukraine" }\end{array}$ \\
\hline $\begin{array}{l}\text { Harmonization of degree } \\
\text { education related to } \\
\text { water resources }\end{array}$ & $\begin{array}{l}2015- \\
2018\end{array}$ & $\begin{array}{l}628900 \\
\text { EUR }\end{array}$ & European Union & $\begin{array}{c}\text { Norwegian University } \\
\text { of Science and } \\
\text { Technology }\end{array}$ \\
\hline $\begin{array}{l}\text { Urban Infrastructure } \\
\text { Project-2(UIP 2) }\end{array}$ & $\begin{array}{l}2014- \\
2020\end{array}$ & $\begin{array}{l}350000000 \\
\text { USD }\end{array}$ & $\begin{array}{c}\text { International Bank } \\
\text { for Reconstruction } \\
\text { and Development } \\
\text { (IBRD); } \\
\text { Clean Technology } \\
\text { Fund } \\
\end{array}$ & $\begin{array}{l}\text { Ministry of Regional } \\
\text { Development, } \\
\text { Construction, Housing } \\
\text { and Communal } \\
\text { services of Ukraine }\end{array}$ \\
\hline
\end{tabular}

Source: developed by the authors on the basis of data retried from http://openaid.gov.ua/uk

According to the industry sectors, the distribution of international projects in Cherkasy region is as follows:education and science ( 3 projects); health care (1 project);government and civil society (2 projects);nuclear safety (1 project);agricultural sector (1 project);restoration of Donbas and IDP (1 project);economic development and trade (1 project);energy and energy efficiency (2 projects);environmental protection (1 project).

As the involvement of Ukrainian regions in active participation in the international projects and programs increases the degree of interregional cooperation, Cherkasy region can be followed as an example for its close cooperation with the other regions of Ukraine and their participation in joint international projects. Creation of network models of interregional interaction forms the area of attraction of regions to the projects.

The project "Safety improvement of ionized radiation sources used in Ukraine" is an opportunity for Ukraine to prevent the unauthorized use of sources of ionizing radiation, which may pose a threat to the public in case of their use with criminal intent (Fig. 4.5). 
The main beneficiary of the project is State Inspection for Nuclear Regulation of Ukraine. Figure 4.5 presents the network model of interregional interaction on the specified project. The regions participating in the project and working with each other are the following: Zaporizhzhia region, Donetsk region, Dnipropetrovsk region, Zhytomyr region, Poltava region, Mykolaiv region, Vinnytsia region, Kyiv, Luhansk region, Kherson region, Kirovograd region, Odessa region, Sumy region, Cherkasy region and Kharkiv region.

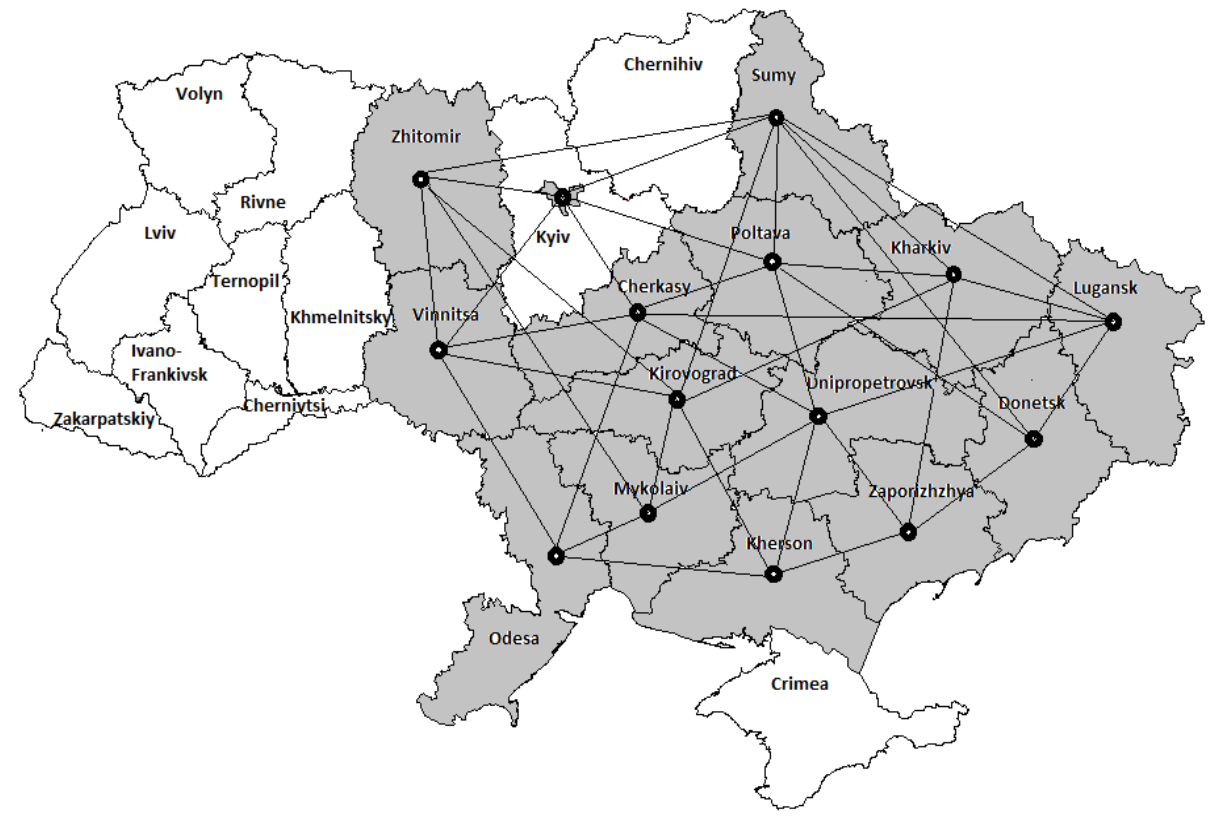

Figure 4.5. Network model of interregional cooperation: safety improvement of ionized radiation sources

Source: developed by the authors

The project "Development of the course for strengthening of local governments in Ukraine (PULSE)" aims at improvement of the legal framework for decentralization in Ukraine, ensuring the contribution of local government bodies in the formation and implementation of decentralization policies, increasing local government resources and strengthening the capacity of the effective management, increasing the capacity and professional level of all groups involved in the reform. The network model of interregional cooperation under this project includes Zaporizhzhia region, Dnipropetrovsk region, Zhytomyr region, Poltava region, Mykolaiv region, Zakarpattya region, Ivano-Frankivsk region, Vinnytsia region, Volyn region, Kyiv region, Lugansk region, Ternopil region, Kherson region, Chernivtsi Oblast, Kirovograd region, Lviv oblast, Odessa region, Rivne region, Sumy region, Khmelnytsky region, Cherkasy region, Chernihiv region and Kharkiv region (Fig. 4.6).

The project «Transparent, accountable and effective budget process at the local level in Ukraine» is supporting the process of decentralization in Ukraine by ensuring effective and accountable management of public budget resources by local government bodies (LGBs). 


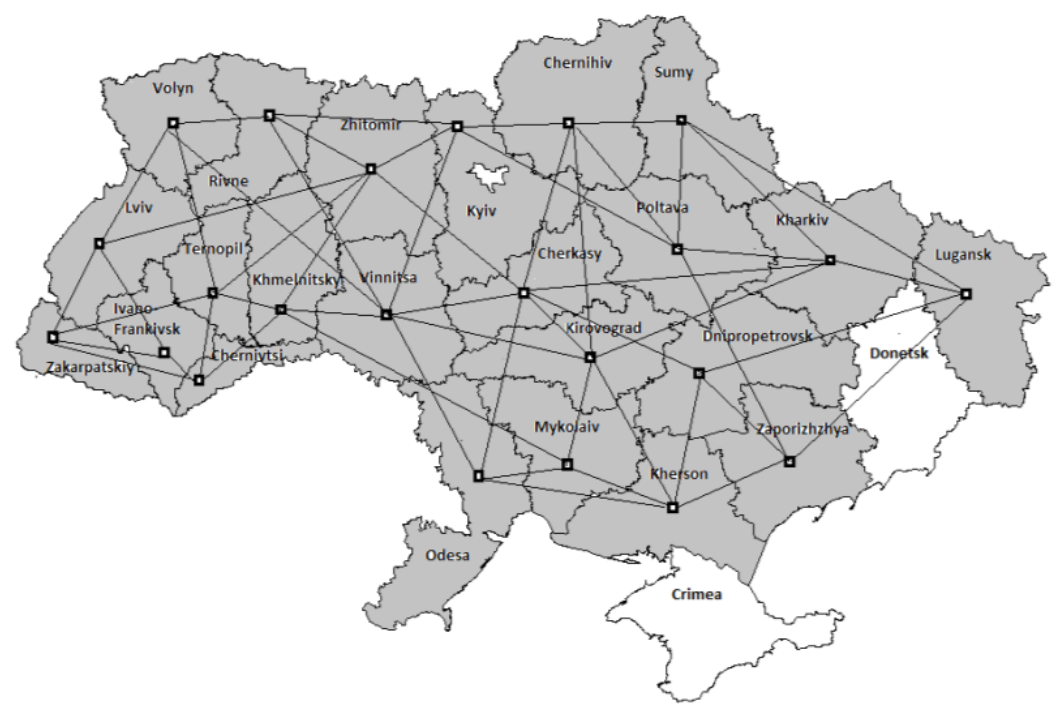

Figure 4.6. Network model of interregional cooperation: development of the course for strengthening of local governments

Source: developed by the authors

The main beneficiary of the project is Ministry of Regional Development, Construction, Housing and Communal Services of Ukraine. The network model of interregional cooperation in this project includes Zaporizhzhia region, Dnipropetrovsk region, Zhytomyr region, Poltava region, Mykolaiv region, Zakarpattya region, Ivano-Frankivsk region, Vinnytsia region, Volyn region, Kyiv region, Lugansk region, Ternopil region, Kherson region, Chernivtsi region, Kirovograd region, Lviv region, Odessa region, Rivne region, Sumy region, Khmelnytsky region, Cherkasy region, Chernihiv region and Kharkiv region (Fig. 4.7).

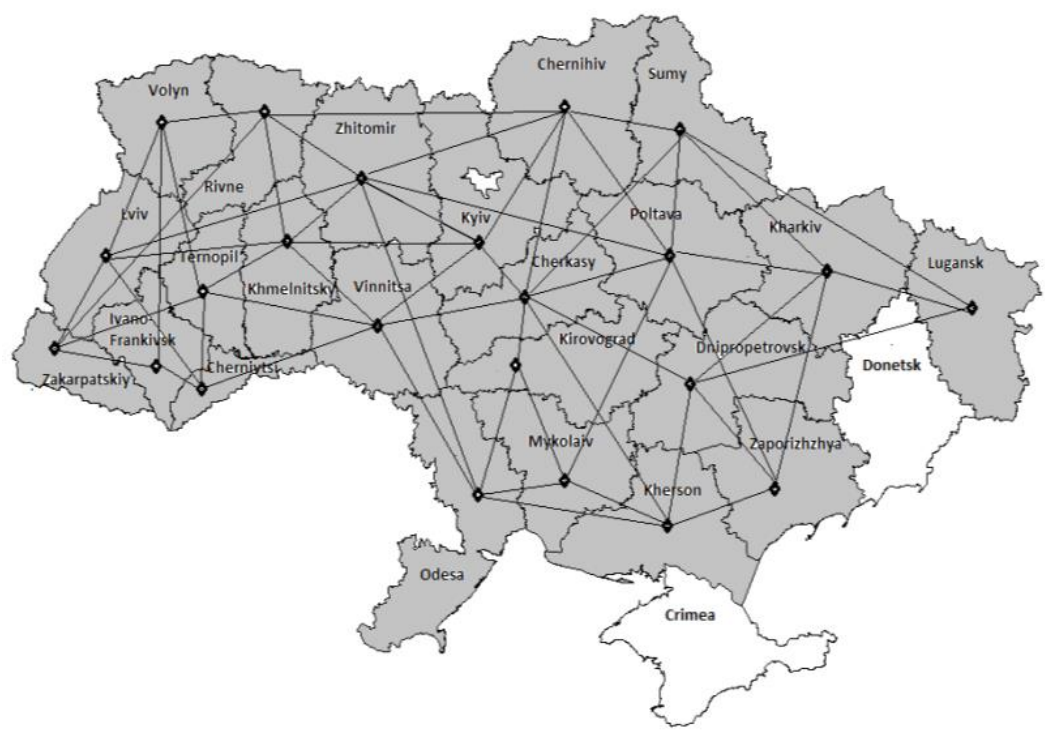

Figure 4.7. Network model of interregional cooperation: transparent, accountable and effective budget process at the local level

Source: developed by the authors 
Project "Harmonization of degree education related to water resources" focuses on increase of the institutional capacity of local government officials in management of local budget resources in a transparent, accountable and effective manner; increase of the capacity and professionalism of civil society and media representatives; creation of the tools for ensuring a transparent, accountable and effective public budget process, increase of the number of united communities with the necessary resources and the ability to provide services to citizens. The main beneficiary of the project is Ministry of Education and Science of Ukraine. The network model of interregional cooperation in this project includes Dnipropetrovsk region, Kyiv region and Cherkasy region (Fig. 4.8).

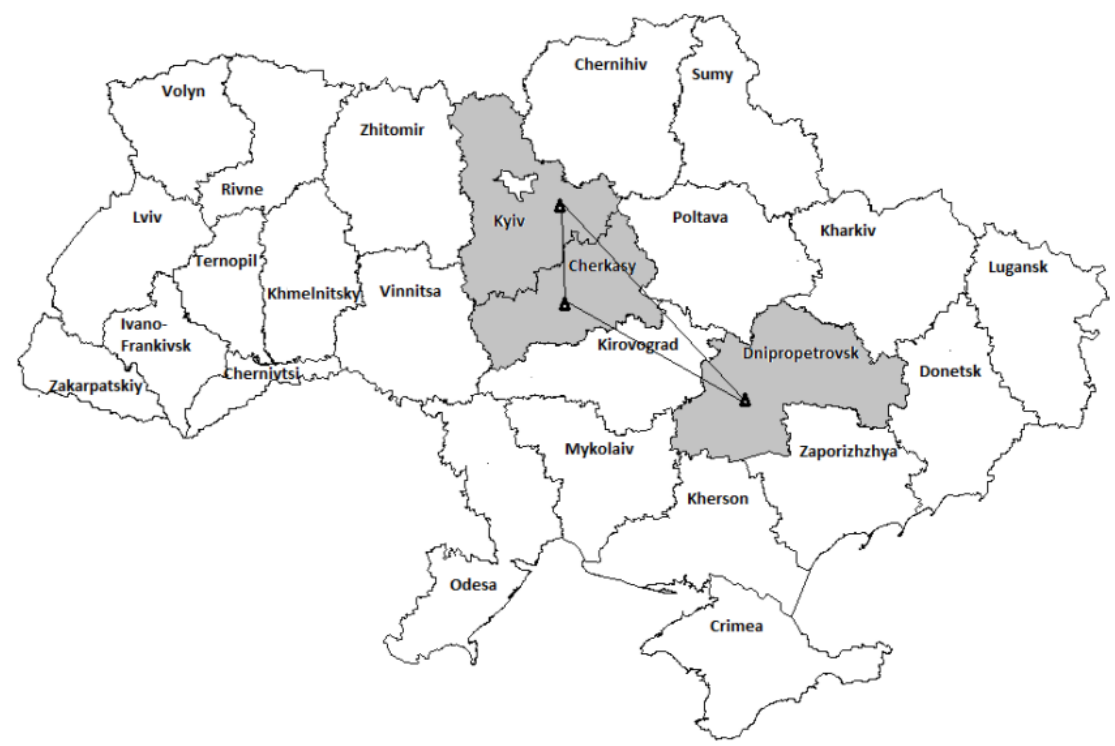

Figure 4.8. Network model of interregional cooperation: harmonization of degree education related to water resources

Source: developed by the authors

Project "Urban Infrastructure Project-2 (UIP 2)" provides utility companies with project assistance to improve the quality and reliability of their services and energy efficiency by improving their institutional capacity and investing in repair and replacement of damaged water supply, drainage and recycling systems of solid waste, as well as improving the ecological situation of the territories by solving the problem of wastewater treatment and the safe disposal of solid household waste. The network model of interregional cooperation of this project includes Donetsk region, Zhytomyr region, Ivano-Frankivsk region, Kyiv region, Ternopil region, Kirovograd region and Cherkasy region (Fig. 4.9).

International activity is one of the prerequisites for enhancing the potential of the region and is a means of attracting financial resources to the regions. Participation in international projects of various types contributes to the increase of socio-economic indicators in the region. International projects in Cherkasy region facilitate the establishment of close cooperation not only with the other countries, but also among the regions of Ukraine. Involvement of the regions in the international projects and programs and their cooperation allows more effectively solving existing problems in different areas of activity and promoting general improvement of their socio-economic development. 


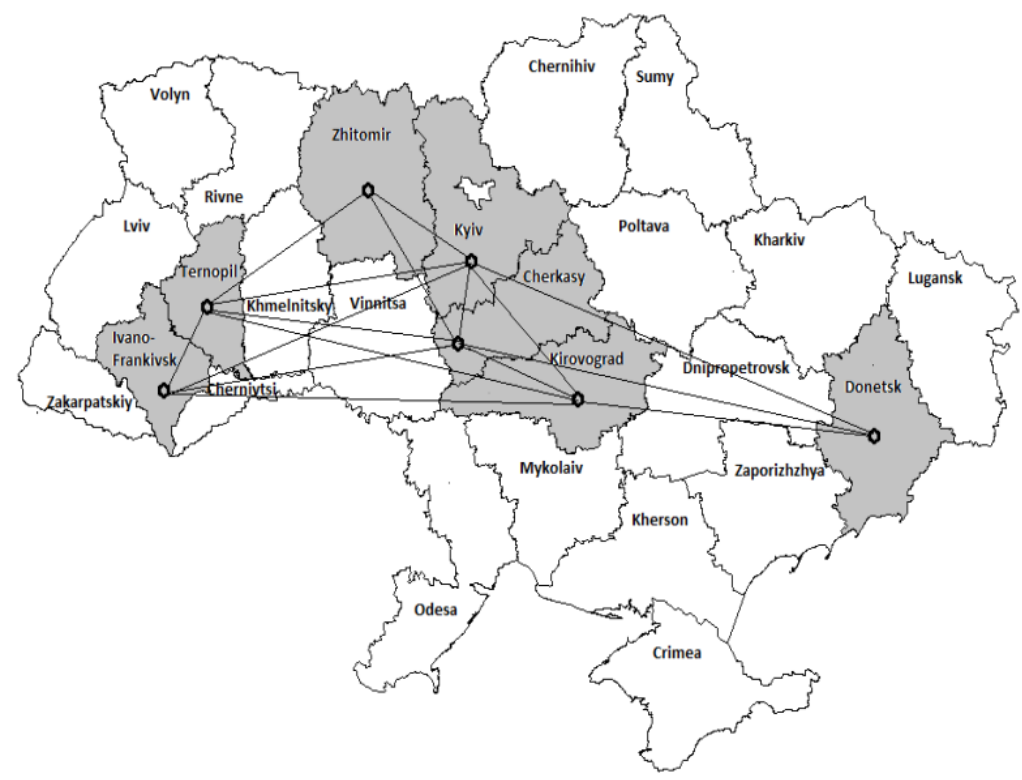

Figure 4.9. Network model of interregional cooperation: urban infrastructure project Source: developed by the authors

The main measures for increase of interregional interactions (according to the Program for the development of cross-border cooperation 2016-2020) opens up new opportunities for the regions, there are:

- deepening of production cooperation, formation of mutual or joint banking, transport and industrial infrastructure;

- development of new forms of cross-border, including Euroregional cooperation;

- development of joint investment projects and development of information component (databases) for investments and creation of new enterprises;

- implementation of a single infrastructure interregional policy;

- stimulating the cooperation of small cities in order to solve their common problems;

- reconciliation of labor force regulation policies among regions;

- combination of efforts to improve adaptation to climate change, reduce man-made risks and spread of diseases (pandemics).

Thus, interregional cooperation through international projects creates conditions for the development of industrial, entrepreneurial, commercial and other types of economic activity among organizations of different regions. Such interaction enables the creation of trading houses, financial and industrial groups and joint manufacturing structures that allow developing cooperative, technological and other economic relations among regions. Altogether, this creates favorable conditions for mutual investments, implementation of joint investment projects aimed at reconstruction and modernization of production facilities, which ensure the processing of raw materials and high efficiency of investments. As a guarantor of further partnerships, development of cooperation in the field of education, science and technology, joint scientific activities, research and development, preparation and retraining of scientific and technical staff, and exchange of specialists is possible. 


\title{
References
}

About the approval of State Strategy for Regional Development for the period up to 2020: Decree of the Cabinet of Ministers of Ukraine dated August 6, 2014 No. 385. Avaliable at: http://zakon4.rada.gov.ua/laws/show

Almashii, V. (2012).The role of local authorities in establishing cross-border cooperation of Ukraine. Compilation of scientific works "Efficiency of Public Administration". Exp. 30, 97-103. Bila, S. O., Babets, I. G., Valushko, I. V., Zhalilo, Y. A. at al. (2011) Interregional cooperation in the system of the new regional policy of Ukraine / [ed. by Y. A. Zhalilo. Kyiv: NISS.

Granberg, A. G. (2006). Regional economics: textbook for university students. Moscow: SU HSE.

Infrastructure provision of intensification of interregional cooperation in Ukraine. Avaliable at: http://www.iepd.kiev.ua/?p=4456.

Kish E. B. System of interregional cooperation of Ukraine with the countries of Central Europe. Avaliable at: http://inb.dnsgb.com.ua/2008-1/08kebkce.pdf.

Kizim, N. A. (2010). Modeling of Sustainable Development of Regions: Monograph. Kharkiv: INZHEK.

Mamonova, V. V. (2009). Regional development. Interregional and cross-border cooperation: textbook; part II / ed. by M. Boytsun, Y. Mudryi, O. Rudik. Kharkiv: Publishing of KhRI NAPA "Master".

Negoda, V. (2014). Program for the development of cross-border cooperation 2016-2020 opens up new opportunities for the regions. Official site of Ministry of Regional Development, Construction, Housing and Communal Services of Ukraine. Avaliable at: http://decentralization.gov.ua/news/item/id/2583

Official portal of coordination of international assistance of Ukraine / Ministry of Economic Development and Trade of Ukraine. Avaliable at: http://openaid.gov.ua/uk

Prokopenko, L. L., Rudik, O. M., Shumlyaev, I. D. (2008). Development of regional cooperation of Ukraine in the context of European integration: scient. Development. Kyiv: NAUD.

Storonianska, I. (2009). Interregional integration processes in Ukraine: trends and prospects for development. Lviv: Institute for Regional Studies of the National Academy of Sciences of Ukraine.

\subsection{HORIZONS OF IMPLEMENTATION OF THE SUCCESSFUL PRACTICES OF CAPITAL MOBILIZATION}

\author{
Yuliia Tkachenko \\ PhD (Economics), Associate Professor, \\ Associate Professorof the Finance Department, \\ Cherkasy State Technological University, Cherkasy, Ukraine
}

In the complex geopolitical conditions, occurring in Ukraine, it is especially relevant and of major priority to solve the issue of interregional cooperation and cross-border cooperation. These forms of cooperation have become widely spread in Ukraine due to the strengthening of European integration processes and implementation of a number of European programs. However, safety of any country starts with its territory protection from any external attacks. In addition, Gazuda L. M. (2014) noted, that the European experience, cross-border 
cooperation (CBC) contribute to the overcoming of territorial imbalances (spatial and territorial ruptures) the socio-economic development of the regions (as the border regions in relation to the central and relatively nearby territories of the neighboring states.

To ensure a sustainable development of border areas, territorial levelling and strategic points for establishing good neighborly relations (partnership) between the two countries the appropriate specialized programs of cooperation have been developed. There are four wellknown programs undertaken by the EU, namely INTERREG, URBAN, EQUAL, LEADER (Mikula, N. A., Zasadko V. V., 2014). These programs include URBAN, which supports the integrated development of urban areas; EQUAL, the goal of which is to create equality and end all forms of discrimination on the labour market; LEADER, aimed at stimulating the development of rural areas through appropriate programs and the program INTERREG is important for the development of joint programs of socio-economic development of the border regions of Ukraine (INTERREG III is the most significant Community project, which redistributes 4.875 billion EUR.

The crossborder cooperation programmes within the framework of the European neighbourhood and partnership instrument (ENPI) have become a modern tool for crossborder cooperation. The total budget of 10 ENPI programs is around 1.1 billion Euro (is made up of contributions from the funds of the INSTRUMENT and the European Regional Development Fund).

According to the approved European Commission Strategy of border cooperation 20072013 and Indicative program of 2007-2010 of cross-border cooperation ENPI Ukraine is involved in 3 following programs:

- "Ukraine - Poland - Belarus"; indicative budget of the Program constitutes 186.201 millionEUR;

- "Ukraine - Hungary - Slovakia - Romania"; indicative budget of the Program is 68.638 million EUR;

- "Black Sea Basin"; indicative budget of the Program is 25.697 million EUR.

Ukraine and the European Union agreed the four new CBC programs to operate in 2016-2020. In particular, the following programs: the "Ukraine-Poland-Belarus" (175.8 million EUR), "Ukraine-Slovakia-Hungary-Romania (73.9 million EUR)," UkraineRomania (60 million EUR) and "Black Sea Basin" (39.1 million EUR). The total amount of funding is in the sum of 350 million EUR for all participating countries.

One of the most effective and far-reaching in terms of funding is the program of crossborder cooperation "Poland-Belarus-Ukraine" for 2014-2020, approved by the European Commission. The program financial plan provides an allocation of over 183 million EUR, of which the largest share of funding is designated for the implementation of the thematic goal 7 - improving of the accessibility of the regions, the development of long-lasting and resistant to climatic influences of transport, communication networks and systems $(30.5 \%$, or 55.9 million EUR), as well as TO 8, in particular, on the implementation of the common objectives in the field of protection and security (44.3 million, or $24.2 \%$ of the total amount of EU funding program), Table 4.2. The current cross border cooperation programs, unlike previous ones, provide for co-funding at the level of the project (minimum 10\%).

The main document for each of the programs of the CBC ENPI is a financial agreement (perennial), which is to be concluded for the entire period and includes the application of an appropriate Joint program document. A financial agreement must be signed by three parties: the Commission, the Joint Management Body (the SOW - Joint Managing Authority) and a partner country. The SOW is responsible for the implementation of the program, in particular, fulfills the administrative and financial functions. 
Table 4.2. Indicative financial plan of the Cross border cooperation program "Ukraine-Poland-Belarus" for 2014-2020

\begin{tabular}{|c|c|c|c|c|c|c|}
\hline \multirow[t]{2}{*}{$\begin{array}{c}\text { Thematic objectives } \\
\text { (TO) }\end{array}$} & \multicolumn{2}{|c|}{ EU Funding } & \multirow[t]{2}{*}{$\begin{array}{l}\text { Minimum } \\
\text { co-funding }\end{array}$} & \multirow{2}{*}{$\begin{array}{c}\text { The rate } \\
\text { of co- } \\
\text { funding, } \\
\%\end{array}$} & \multicolumn{2}{|c|}{$\begin{array}{l}\text { The total amount of } \\
\text { funding }\end{array}$} \\
\hline & Euro & $\begin{array}{c}\text { Share } \\
\%\end{array}$ & & & Euro & $\begin{array}{c}\text { Share } \\
\%\end{array}$ \\
\hline $\begin{array}{l}\text { TO } 3 \text { - Promotion of } \\
\text { local culture and } \\
\text { heritage preservation }\end{array}$ & 32272159.5 & 17.6 & 3570024.6 & 11.06 & 35842184.1 & 17.8 \\
\hline $\begin{array}{l}\text { TO } 7 \text { - Improving } \\
\text { the accessibility of } \\
\text { the regions, the } \\
\text { development of long- } \\
\text { lasting and resistant } \\
\text { to climatic influences } \\
\text { of transport, } \\
\text { communication } \\
\text { networks and } \\
\text { systems }\end{array}$ & 55855660.6 & 30.5 & 6178888.7 & 11.06 & 62034549.3 & 30.8 \\
\hline $\begin{array}{l}\text { TO } 8 \text { - Common } \\
\text { tasks in the field of } \\
\text { protection and } \\
\text { security }\end{array}$ & 44270782.8 & 24.2 & 4897341.4 & 11.06 & 49168124.2 & 24.4 \\
\hline $\begin{array}{l}\text { TO } 10 \text {-Promote the } \\
\text { management of } \\
\text { borders, security, } \\
\text { mobility and } \\
\text { migration }\end{array}$ & 33099650.7 & 18.1 & 3661563.7 & 11.06 & 36761214.4 & 0 \\
\hline Technical assistance & 17579930.4 & 9.6 & 0 & 0 & 17579930.4 & 8.7 \\
\hline Total & 183078184.0 & 100 & 18307818.4 & 10 & 201386002.4 & 100 \\
\hline
\end{tabular}

Source: compiled by the author on the basis of data retried from http://www.pl-byua.eu/upload/pl/JOP_PL-BY-UA_2014-2020_FINAL_ENG.pdf

Thus, the cross-border cooperation provides not only the solution of common problems of border areas, addressing the issue of interethnic conflicts but also brings within EU policy a considerable amount of investment, aimed at the development of the cross-border areas of the country.

\section{References:}

Commission implementing decision about the Joint Operational Program Poland-BelarusUkraine 2014-2020 for the ENI Cross-Border Cooperation program for the years 2014-2020 to be financed from the general budget of the European Union. Brussels. 17.12.2015 C (2015) 9138 final. Ref. Ares (2015) 5993060 - 22/12/2015. Avaliable at: http://www.pl-byua.eu/upload/pl/JOP_PL-BY-UA_2014-2020_FINAL_ENG.pdf.

Gazuda, L. M., Rubish, M. A. (2014). Joint investment projects, cross-border cooperation and foreign economic activity of the region. Scientific bulletin of Mukachevo State University.Economics Series. Issue 1 (1), 55-62. 
Information on implementation of the CBC European program and partnership instrument in 2007-2013 years. Avaliable at: http://sfs. gov.ua/diyalnist-/mijnarodne-/integratsiya-ukrainido-es/integratsiya-ukraini-do-es/inf_dovidka.

Mikula, N. A., Zasadko, V. V. (2014). Cross-border cooperation of Ukraine in the context of European integration: monograph. Kyiv: NISD.

\title{
4.3. APPROACHES IN POSITIONING OF INTERNATIONAL INSTITUTIONS OF STARTUP ACCELERATION AND INCUBATION
}

\author{
Michael Ryabokon \\ Graduate student, Cherkasy State Technological University, Cherkasy, Ukraine \\ Yuriy Pikalov \\ Graduate student, Cherkasy State Technological University, Cherkasy, Ukraine
}

Modern stage of global development is involved in globalization processes, characterized by enhancement of innovative activity in all spheres as well as harnessing high technology and manufacturing innovative science-intensive products, which are the key factors of steady economic growth for majority of the developed countries of the world. At the same time, it seems clear that the innovative economy cannot be built without an active development of enterprises, conducting research and development activities. Within the framework of forming the innovative structure such institutions as business incubator, technopark, technopolis, engineering school, high-tech centers, etc. have been developed and focused on creating favorable conditions for innovative activities, support and development of small-scale innovative entrepreneurship.

The above-mentioned forms of scientific and technological business are a system that integrates science, education and production. It is an essential infrastructure element of national innovative systems, which promotes formation of innovative economy by the way of: development of science-intensive technologies and enterprises; selection and support of the promising scientific projects; commercialization of research findings and scientific and technological developments; rendering various services to small business entities, primarily, related to development of firms in the startup phase, etc. At the same time, today we have a relative dispersion of organization forms of such kind of activities. Thus, a justification of the axiomatics of the elements of venture entrepreneurship efficiency is of particular interest. A study of different aspects of entrepreneurship formation and development in terms of the innovative infrastructure is contained in the papers of following authors: Ganamotse, G. N., Samuelsson, M., Abankwah, R. M., Anthony, T., \& Mphela, T. (2017); Dellermann, D., Lipusch, N., Ebel, P., \& Leimeister, J. M. (2017); DaSilva, C. M., \& Gurtner, P. (2017); Gonzalez-Uribe, J., \& Leatherbee, M. (2017); Shane, S., \&Nicolaou, N. (2017); Yakowicz, W. (n.d); Graham, P. (2009); Manalac, K. (2016). A study of the innovative practice of business incubation, which allows identification of management specifics in different countries, is contained in the works of following authors: Sazonets, I. L., \& Gladchenko, A. Y. (2011); Petkova L. O., Marushhak D. Y. (2018), at all. At the same time, for today there are no studies and publications related to identification of approaches to positioning of clusters of the enterprise innovative activity acceleration that will make it possible to find the most efficient approaches to acceleration. Therefore, this study is aimed at identification of the best practices 
of international scientific and technological business functioning based on calculation of clusters.

Having identified the key parameters of the analyzed institutions, using the "Statistics7" program package, we have combined the input data to address the challenge of cluster analysis, consisting in classification breakdown, which meets the criterion of optimality. Proceeding from the research target, the rule "Single Linkage" was chosen as the key function. According to this rule, two objects, being the closest to each other, i.e. which have maximum degree of similarity, are combined at the first step. At the next step the object, which has maximum degree of similarity with one of cluster objects, joins them. This method is also called the method of the closest neighbor as the distance between two clusters is defined as the distance between the closest two objects in different clusters. 1 - Pearson (1 minus coefficient of Pearson's correlation) was chosen as a degree of distance as far as the given data cannot be presented as points in k-dimensional space. When addressing a huge amount of problems in economics or sociology, the objects can be presented as points in k-dimensional space. In this case it is expedient to use 1 - Pearson (1 minus coefficient of Pearson's correlation).

In order to conduct cluster analysis we have selected 19 institutions in the sphere of acceleration of the innovative activity and the following indicators, which are basic characteristics of their functioning: initial investment *thousand USD); share in the project (\%); total number of projects, registered in 2017; number of successful projects; amount of time to be spent on acceleration; time period of incubation program; capitalization (million USD); number of sectoral areas under consideration. Thus, the first indicator, which is of utmost importance while defining the effectiveness of building the accelerating institutions, is the amount of initial investment. Among the largest and the most popular institutions of similar format, which were selected for this study, their distribution is quite uneven. Therefore, this aspect is of utmost importance.

The next aspect of positioning of institution in the sphere of startup acceleration and incubation is represented by dynamics of the number of registered projects and the number of successful projects. In this aspect differentiation among the analyzed institution is also dispersive. The next aspect of positioning of institutions in the sphere of startup acceleration and incubation is represented by capitalization. There was found no homogeneous situation in relation to this indicator among the analyzed enterprises. The level of capitalization in the selection of the analyzed enterprises is quite differentiated (Fig. 4.10).

Thus, since 2005 the total market capitalization of all companies of YC, which funded 1,430 companies and almost 3,500 founders, makes more than 5 billion USD. SparkLabs has insignificant capitalization in comparison with the above-stated institution, which makes 1.2 billion USD. However, SparkLabs is quite typical mechanism of positioning, which is reflected in the following elements: they invest up to 40,000 USD in all startups in exchange for up to 6\% of shares in every startup. This share is a subject to negotiations depending on the amount and investment status of project launch; in the course of acceleration program startups take part in our training sessions, where they have a chance to learn and communicate with the well-known Korean and international entrepreneurs. Besides, during office work startups can have a feedback from general partners of SparkLabs; SparkLabs provides free-of-charge office premises in MARU180 center for the startup in Korea and benefits for the amount over 900,000 USD, starting from cloud services, legal advisers and SendGrid. Besides, SparkLabs is the first Korean member of Global Accelerator Network (GAN), which means that our startups also can be provided with various benefits of GAN. For today, Techstars Ventures have venture capital in the amount of $400 \mathrm{mln}$. USD. 
The Fund Techstars Ventures 2017 also has 265 million US USD and now they invest the amount of 150 million US USD from the third fund (according to their website). They invest in the companies-accelerators, established by graduates-accelerators. Figure 1 shows total market capitalization of the analyzed enterprises, specialized in startup acceleration and incubation in 2017. We can see quite significant differentiation among the analyzed enterprises, specialized in startup acceleration and incubation in terms of market capitalization. Thus, Y combinator and Techstars have the determinant amounts of capitalization that, in our opinion, is caused by the fact that they were the first institutions of that type. In general, starup accelerators of the USA, prevail on the market of innovations and startups. For instance, among the analyzed enterprises by the level of capitalization the European and Asian enterprises have in average from 200 to 500 million USD. However, startup accelerators from the USA have higher indicators on account of running certain enterprises after their launch. The last indicator within the framework of the author's analysis is a differentiation by the number of sectoral areas under consideration. It should be noted that the emphasis in today's general trends of venture investment is laid on sectoral specialization.

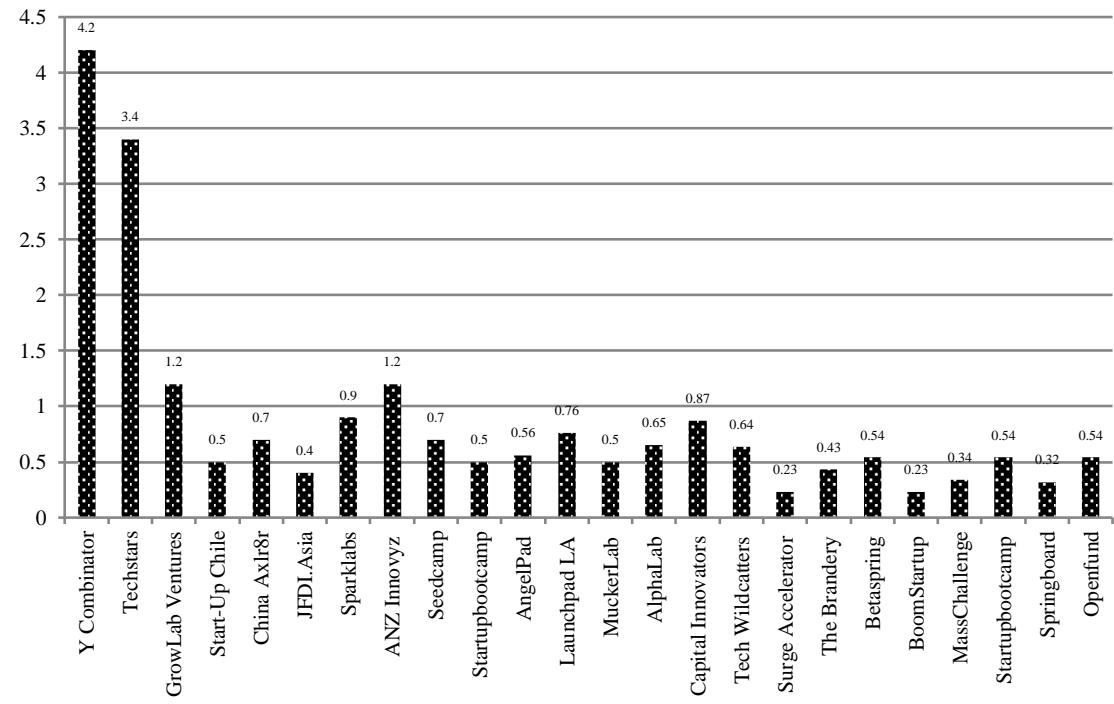

Figure 4.10. Market capitalization of the analyzed enterprises, specialized in startup acceleration and incubation in $\mathbf{2 0 1 7}$

Source: compiled by the authors on the basis of data retried from https://www.seeddb.com/accelerators

Although, among the analyzed institutions we can see quite insignificant differentiation of project, which they admit (not exceeding 8 projects). At the same time, the basic today's trend is an enhancement of the role of the enterprises, specialized in startup incubation and acceleration (Fig.4.11). 


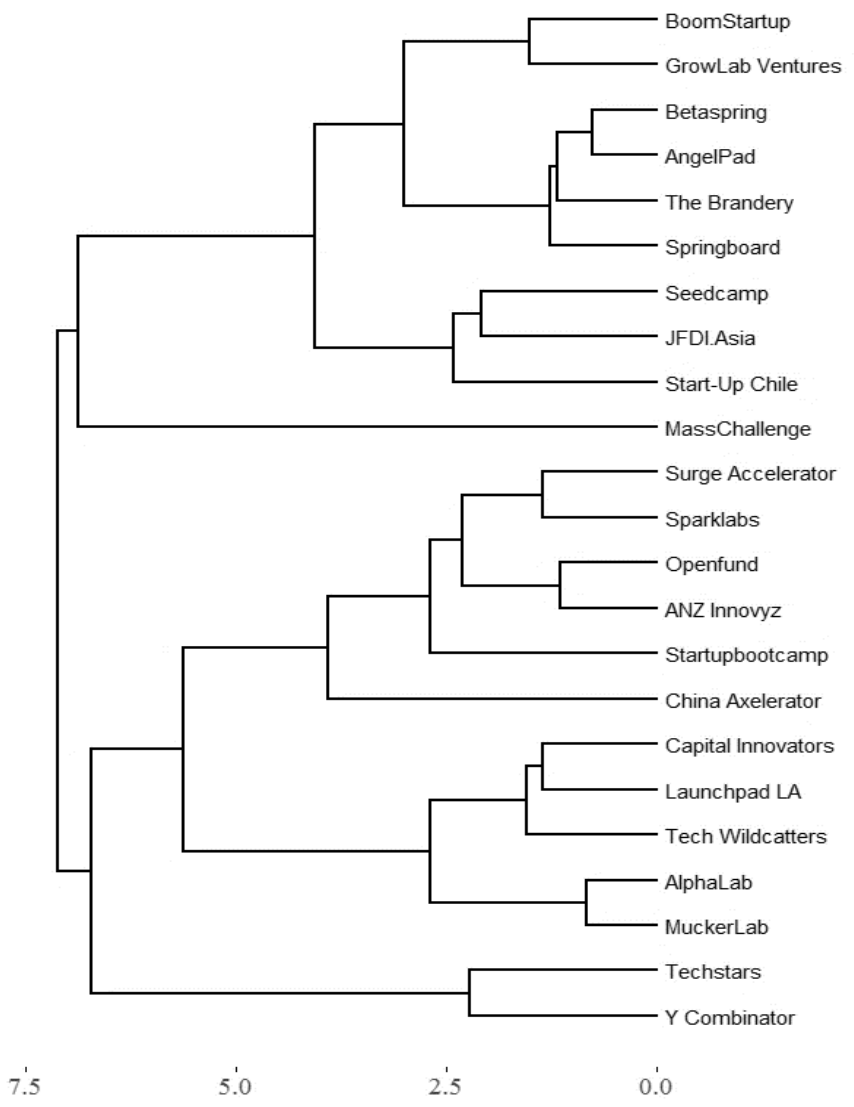

Figure 4.11. Basic characteristics of approaches in positioning of certain international institutions of startup acceleration and incubation in 2017

Source: compiled by the authors on the basis of data retried from https://www.seeddb.com/accelerators

Figure 4.11. shows general results of cluster analysis related to approaches in positioning of certain institutes of startup acceleration and incubation in 2017. Using this method, we have obtained a hierarchic structure of clusters with the above-stated characteristics, which allows identifying homogeneous formations - "clusters". As we can see on the Figure 2 three cluster formations can be identified at the distance level from 2.5 to 5 . 10 institutions, which undoubtedly occupy a significant segment on the global market, have grouped into cluster No.1: Start-Up Chile, China Axelerator, FDI.Asia, Seedcamp, BoomStartup, GrowLab Ventures, Betaspring, AngelPad, The Brandery, Springboard.

The peculiar features of institutions of the first cluster, distinctive from the other cluster formations, are represented, first of all, by their geographic location in the developing countries. Modern characteristics of institutions of this cluster consist in the insufficient infrastructure, which is demonstrated by relatively low indicators of political and economic stability, Ease of Doing Business, costs on legal proceedings and high inflation processes. The above-listed aspects, jointly with a certain outflow of high skilled personnel, create a precedent when the indicator of total amount of registered projects (\% from the number of applications) is much 
higher than in the second and third clusters. Thus, for instance, Start-Up Chile (SUP) is a typical representative of the first cluster Start-Up Chile (SUP). It is generally available startup accelerator, created by the Chilean government for high-capacity entrepreneurs to launch their startups and use Chile as a basis. As a rule, projects raise $90 \%$ of the total amount of costs on program as well as by the way of reimbursing the costs or as advance payment. However, project startup should provide $10 \%$ of the rest of money. Chilean applicants may submit an application for additional 10 million of Chilean peso if they live abroad and obtained Master's Degree from a leading foreign university. Although, $10 \%$ of share (in the project) is the highest indicator among the analyzed clusters. Y Combinator and Techstars are two institutions, which today have the largest audience of investors and startups, which have involved or wish to get involved in venture investment, have grouped in the cluster No.2. First of all, basic characteristics of the enterprises of the second cluster are represented by the amount of initial investment, which is much more than in the first and third clusters. Such context is possible on account of considerable capitalization. These two institutions are the first formations of this type. This, Y Combinator has been founded in 2005. From 2005 to 2008 one program had been conducted in Cambridge, Massachusetts, and another one had been conducted in MountainView, California. In January, 2009 Y Combinator announced that Cambridge program would be closed and all further programs would be conducted in the Silicon Valley. In 2009 Sequoia Capital has carried out investment round in the amount of 2 million USD that were invested in Y-Combinator. It will enable this company to invest in about 60 companies per year, in contrast to their previous investment in 40 companies per year. Techsters also have the characteristics, similar to Y Combinator. Sturtaps have an opportunity to submit an application to take part in the program of Techstars, and their viability will be evaluated by the Managing Director of the program that they apply for as well as by the Screening Committee, consisting of diverse members of Techstars network. In exchange to $6 \%$ of ordinary shares, every company, admitted by Techstars, receives 20,000 USD; plus a convertible note in the amount of 100,000 USD, access to Techstars network for a lifetime, more than one million USD of benefits and threemonth program of accelerators, which is conducted in three stages.

Cluster No.3 contains a group of three institutions, which, in contrast to the others, have higher specialization and also put emphasis on their positioning in less number of projects, which are admitted to acceleration program. The third cluster of institution is characterized by less preparatory period. Thus, the analyzed enterprises of the first and second cluster have 90 days of acceleration program in average, although the enterprises of the third cluster conduct the acceleration program during 70 days.

One of the typical representatives of the third cluster is AlphaLab - national startup accelerator, founded in 2008. As a chartered member of the Global Accelerator Network (GAN) and one of the first ten accelerators of the entire world, AlphaLab has invested and collaborated with 113 companies, including 12 acquired companies. AlphaLab network consists of the leading entrepreneurs, investors and mentors in Pittsburg region and other countries. Success stories, related to startups in the highly-developed companies, include NoWait (acquired by Yelp), Jazz, Black Locus (acquired by Home Depot), Shoefitr (acquired by Amazon) and The Zebra. AlphaLab is also a part on the startup stage of seed fund, which has invested over 50 million USD in more than 160 companies, which jointly raised over 1.3 billion USD. These companies include ModCloth, 4Moms, Civic Science, mobile technologies (acquired by Facebook Facebook) and ShowClix. In general, analyzing structural elements of the enterprises of the third cluster, it should be noted that, according to their characteristics, these enterprises have more selective approach to consideration and acceleration as well as incubation of new projects. In order to compare the difference in approaches to the above-stated process, we have 
calculated a configuration of the distances of cluster formations using the method of $\kappa-m e a n s$ (Fig. 4.12).

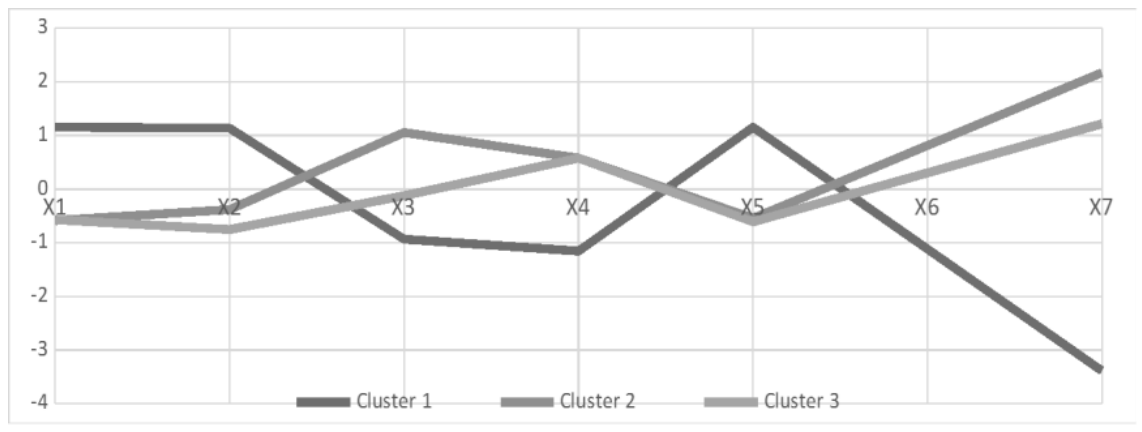

\section{Figure 4.12. Configuration of the distances of cluster formations using the method ofk-means in approaches to startup acceleration and incubation process}

Source: compiled by the authors on the basis of data retried from https://www.seeddb.com/accelerators

Figure 4.12 shows that, despite of the fact that all clusters have quite different approaches to positioning; the total financial return in all the analyzed clusters is quite similar. Therefore, in the course of clusterization of the enterprises, specialized in acceleration of scientific and technological entrepreneurship, we have justified the indicators, which demonstrate the key system parameters of positioning of the largest ones by capitalization and other quantitative and qualitative indicators. First of all, it is quantitative and qualitative methods and forms of startup investment, which make it possible to optimize and enhance effectiveness of the startup phase of acceleration or incubation. Secondly, it is quantitative characteristics of share in the project (\%), which enables us to determine the extent of the developers' readiness to alienate a certain part of the project. Thirdly, it is a total amount of the registered projects ( $\%$ of the number of applications), which determines general principles and methods for selection and its impact on final results. Fourthly, it is a number of successful projects. This indicator clearly determines which projects have a capacity for effective exit and positioning. Fifthly, it is an amount of time, spent on acceleration, which enables us to understand the difference between the existing training programs and to single out effective elements. Sixthly, it is the level of capitalization, which makes it possible to justify the impact of the amount of capitalization on final incomes. Seventhly, it is a quantity of sectoral areas under consideration. This indicator is also highly relevant in terms of understanding of the existing trends in effectiveness of organizing the process of acceleration or incubation. Justification and calculation of the above-stated indicators enabled us to conduct cluster analysis, using the approaches to functioning of the enterprises, specialized in acceleration and incubation of venture businesses as well as to develop the following classification: accelerators and incubators-followers, which have a distinctive feature of insufficient infrastructure, demonstrated by relatively low indicators of political and economic stability, Ease of Doing Business and, as a result, they are characterized by significant share in projects, undergoing acceleration or incubation, which is much higher than in other clusters; specific accelerators and incubators, which have larger specialization, and they also lay emphasis in their positioning on the higher level of readiness of the projects, which are admitted to acceleration program along with a very slight period of acceleration. 
Based on the developed configuration of the distances of cluster formations using the method of к-means in approached-to-startup acceleration and incubation process, we have found out that, despite of the fact that all clusters have quite different approaches to positioning, the total financial return in all of the analyzed clusters is quite similar. Therefore, further analysis of the most effective accelerators and incubators is of considerable interest in terms of finding the best practices in the area of venture business acceleration.

\section{References}

DaSilva, C. M., \& Gurtner, P. (2017, January). Accelerators: An Assessment of Acceleration Models. In Academy of Management Proceedings (Vol. 2017, No. 1, p. 12198).Academy of Management.

Dellermann, D., Lipusch, N., Ebel, P., \& Leimeister, J. M. (2017). Building Your IoT Ecosystem: Proposing the Hybrid Intelligence Accelerator.

Ganamotse, G. N., Samuelsson, M., Abankwah, R. M., Anthony, T., \& Mphela, T. (2017). The Emerging Properties of Business Accelerators: The Case of Botswana, Namibia and Uganda Global Business Labs. Journal of Entrepreneurship and Innovation in Emerging Economies, 3(1), 16-40.

Gonzalez-Uribe, J., \& Leatherbee, M. (2017). The effects of business accelerators on venture performance: Evidence from start-up chile. The Review of Financial Studies, 31(4), 1566-1603.

Graham, Paul (January 2009). "California Year-Round”. Y Combinator. Avaliable at:http://old.ycombinator.com/ycca.html.

Main statistics of worldwide Seed Accelerators (2017).Avaliable at: https://www.seeddb.com/accelerators.

Manalac, Kat (2016). "YC Office Hours in 11 Countries This Fall”.Y Combinator Posthaven.Avaliable at: https: //blog.ycombinator.com/yc-office-hours-in-11-countries-this-fall.

Petkova L. O., Marushhak D. Y. (2018). Peredumovy zrostannya produkty vnosti $v$ Ukrayini.Zbirny`k naukovy`x pracz`Cherkas kogo derzhavnogo texnologichnogo universy`tetu. Seriya: Ekonomichni nauky, (48), 91-97.

Sazonets, I. L., \& Gladchenko, A. Y. (2011). Dialectical unity of globalization and regionalization processes within world economy. Actual problems of economics, (126), 66-72.

Shane, S., \&Nicolaou, N. (2017).Exploring the changing institutions of early-stage finance.Journal of Institutional Economics, 1-17.

Techstars Alumni Companies. Techstars. (2017). Avaliable at: https://www.techstars.com/companies.

The BIC - Business and Innovation Centre (2017).Avaliable at: http://bicminho.eu/what-is-aeu-bicl?lang $=$ en .

Yakowicz, W. (n.d.). The 15 Best Startup Accelerators in the U.S. Avaliable at: https://www.inc.com/will-yakowicz/the-15-best-startup-accelerators-in-the-us.html. 


\title{
4.4. EVALUATION OF THE EFFECTIVENESS OF PHASES I AND II OF THE EU/ UNDP PROJECT "COMMUNITY BASED APPROACH FOR LOCAL DEVELOPMENT": THE REGIONAL ISSUE
}

\author{
Yuliia Tkachenko \\ PhD (Economics), Associate Professor, \\ Associate Professorof the Finance Department, \\ Cherkasy State Technological University, Cherkasy, Ukraine
}

A long and protracted period of economic and social depression in Ukraine has resulted in a catastrophic destruction of the existing economic system and the logical reaching point of bifurcation, the onset of which is either the beginning of a new stage of development of the country and its territories on the basis of a qualitatively higher type of organization or the end (final destruction) of the former organization. Under the circumstances the only way for realization of the first scenario is the way of radical reform. Ukraine has implemented the reform of local self-government and power decentralization, which involves the transfer of more powers and resources at the level of territorial communities. An important component and the key to the implementation of this reform is the formation of capable communities, through the merger of territorial communities.

The need for accelerated progress of Ukraine on the path of a sustainable development, economic growth combined with an active social policy of the state, democratization of all components of the public life, requires the formation of a qualitatively new regional policy. The strategic objective of this policy is the regulatory creation of conditions for dynamic, balanced socio-economic development of Ukraine, its regions and territories, raising the living standard and ensure compliance with state-guaranteed social standards for every citizen regardless of place of residence, as well as deepening the process of market transformation and the effective use of potential of regions and overcoming the depressive state of the individual territories. The regions, directly involved in policies of higher authorities and developing their own ones, have a leading role in the implementation of the specified motion vector of the national economy.

A sustainable economic development, the revival of competitive industries, full use of the potential of the country and the rising living standards of the population require appropriate investments in the production and social sphere. The analysis of the international project experience (Berezina, O. Yu., Tkachenko, Yu. V., 2016) shows that in many developed countries one of the important tasks for local governments in the state is the focus for the search of alternative funding and cooperation with international funds, programs and grants.Ukraine has also recently introduced design technologies to the management system processes of the regional development.Currently in Ukraine over a thousand projects of assistance from the European Union are being implemented. All of them have state registration and their total Fund is about 262.7 million EUR. Projects are implemented through national and regional aid programmes, the EU programme cross-border cooperation, Twinning mechanism, the educational Tempus programme, a Comprehensive programme of institutional restructuring and the Instrument for nuclear safety cooperation, and so on.

The EU and UN development programme contribute to support Ukraine on the path of sustainable human development, aimed at achieving a prosperous, democratic and strong state in which nobody is left aside and the each opinion is considered. UNDP is guided by the Millennium development Goals and UN Conventions joined by Ukraine. The programme aims to combat poverty in rural areas through the introduction of effective models of social 
and economic development and the environment, and by supporting democratic processes, institutions and networks. Also the UN development programmes help strengthen partners at national and local level that develop stable solutions to provide a comprehensive national, regional and local development. UNDP achieves its goals in partnership with the Cabinet of Ministers of Ukraine, other UN agencies, development agencies, civil society and local communities. The program helps to find a Ukrainian solution to global and national challenges in the field of development through a series of initiatives based on the experiences and comparative advantages of UNDP.

Among the variety of projects contributing to the formation, development and prosperity of the country "Local development, oriented on the community" (a Joint project of EU and UNDP) is one of the most ambitious and successful projects, implemented in our state. The joint project EU/UNDP "Local development, oriented on the community" (LDC) is a long-term and comprehensive initiative to strengthen capacities aimed at promoting sustainable local development in Ukraine. The project supports management, with the participation of communities and initiatives implemented by the communities to improve living conditions of people in rural and urban areas across the country. LDS pays special attention to the restoration of social and communal infrastructure in the priority areas of health, ecology and water resources management, management improvement of the housing sector, energy efficiency and local economic development.

Being an Agency of the United Nations, specializing in development issues, UNDP supports strategic initiatives aimed at capacity development to promote inclusive growth and sustainable human development. By partnering with national, regional and local authorities, civil society and the private sector, UNDP strives to support Ukraine on the path to overcoming poverty, human development, achieving equitable outcomes, protecting the environment and promoting democratic governance. The project EU/UNDP "Local development, oriented on the society" in its life-cycle is divided into phases.

Phase I of the LDC Project began in 2008, after which the second phase started in June, 2011. During these two phases health services, access to clean water and waste disposal, educational environment and safety of the population improved and was achieved through the introduction of projects to communities with the participation of the communities themselves that is upgrade of 1323 schools/kindergartens, 599 health facilities, 110 water supply projects, 17 environmental protection projects, 556 of energy efficient street lighting and 27 other initiatives.

The project "Local development, oriented on the community" started its activity in Cherkasy region on August 28, 2008 with the signing of the tripartite agreement on cooperation. During the presentation of the Project to representatives of the district authorities applications for participation in the selection procedure of districts of the project were offered to be submitted. According to the results 8 pilot districts and 4 reserve ones were chosen: Uman, Kanev, Kamiansky, Horodyschenskyi, Shpola, Talne and Chigirinsky, Smelyansky, Cherkasy, Khrystynivskiy and Katerynopil regions.The project in total received 117 applications from rural councils, 40 pilot communities of which were selected by the regional Committee, composed of representatives of regional state administration, regional Council, district authorities and project coordinators (table 4.3).

The data given in the table demonstrate varying levels of activity of representatives of the rural authorities. The highest activity level was observed in Gorodyshche (63\% of all rural district councils) and Shpola (72\% of all rural district councils) districts. In these regions the village heads filed the largest number of applications for participation in the project. 
Table 4.3. Community participation in phase I of the Project "Local development, oriented on the community"

\begin{tabular}{|l|c|c|c|c|}
\hline \multicolumn{1}{|c|}{$\begin{array}{c}\text { The name of the } \\
\text { district }\end{array}$} & $\begin{array}{c}\text { The number of } \\
\text { population clusters } \\
\text { in the region }\end{array}$ & $\begin{array}{c}\text { The number } \\
\text { of granted } \\
\text { applications }\end{array}$ & $\begin{array}{c}\text { Number of } \\
\text { selected } \\
\text { communities }\end{array}$ & $\begin{array}{c}\text { The number of } \\
\text { reserved village } \\
\text { councils }\end{array}$ \\
\hline Umansky & 54 & 7 & 5 & 2 \\
\hline Gorodyschenskiy & 32 & 12 & 5 & 3 \\
\hline Zvenigorodsky & 41 & 16 & 5 & 3 \\
\hline Shpolyansky & 38 & 26 & 5 & 3 \\
\hline Chygyrynsky & 37 & 11 & 5 & 3 \\
\hline Kanivsky & 60 & 10 & 5 & 3 \\
\hline Talnivsky & 43 & 17 & 5 & 3 \\
\hline Kamiansky & 30 & 18 & 5 & 23 \\
\hline Total & - & 117 & 40 & retried \\
\hline
\end{tabular}

Source: compiled by the author on the basis of data retried from http://cba.org.ua/ua/biblioteka/zviti-proektu

In general, it can be concluded that the process of selection of communities in Cherkasy region took place efficiently. This is evidenced by the fact that the rate of replacement of communities is very low, it was $5 \%$ (2 communities were changed due to the fact that the priorities of society's development did not coincide with the priorities of the project). In general, the community organizations developed 54 projects that were approved by the Committee of UNDP for the selection of projects (table 4.4).

Table 4.4. Priorities for community micro-projects in Cherkasy region

\begin{tabular}{|c|c|c|c|}
\hline \multirow{2}{*}{ The total number } & \multicolumn{3}{|c|}{ In preference manner } \\
\cline { 2 - 4 } & Energy saving & medicine & Drinking water quality \\
\hline 54 & 26 & 22 & 6 \\
\hline Total cost & UNDP funds & Local budgets & Business tools \\
\hline 7077357 & 3569609 & 2768110 & 185.889 \\
\hline
\end{tabular}

Source: compiled by the author on the basis of data retried from http://cba.org.ua/ua/biblioteka/zviti-proektu

The above data show that only 3 project priorities constituted the main problems, solved by Cherkasy communities. The distribution of projects of Cherkasy region districts is presented in table 4.5 .

Phase II of the project was laumched in Cherkasy region on July 5, 2011. It began with the signing of the tripartite agreement of partnership with the Cherkasy regional state administration, Cherkasy regional Council and Project of 39 communities from 9 districts (Katerynopil, Zvenigorodskyi, Lysyansky, Mankovsky, Shpola, Uman, Khrystynivka, Korsun-Shevchenko and Smilansky) participated in the second phase of the project "Local development, oriented on the community" in Cherkassy region on the main quota. It resulted in 39 public associations, which today have successfully implemented and reported for the implementation of 39 projects for a total amount of 6283590,00 UAH, EU/UNDP funds constitute 3156952.00 UAH, the budgets of all levels - 2614128.00 UAH (regional 267785.00 UAH, districts - 652272.00 UAH, villages - $1694071.00 \mathrm{UAH}$ ); sponsors 463213.00 UAH, community funds - 387196.00 UAH. In addition to the main phase, Cherkasy implemented three new components: experience replication; renewable energy and economic one. 
Table 4.5. The distribution of projects by Cherkasy region districts in the first phase of the Project "Local development, oriented on the community"

\begin{tabular}{|c|c|c|c|c|c|c|c|c|c|c|}
\hline \multirow[t]{2}{*}{$\begin{array}{c}\text { The name of the } \\
\text { district }\end{array}$} & \multirow[b]{2}{*}{ 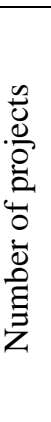 } & \multirow[b]{2}{*}{ 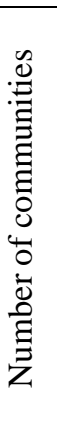 } & \multicolumn{3}{|c|}{$\begin{array}{l}\text { In preference } \\
\text { manner }\end{array}$} & \multicolumn{5}{|c|}{ Funding } \\
\hline & & & 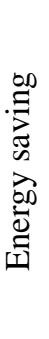 & 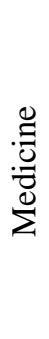 & 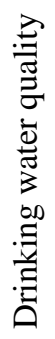 & 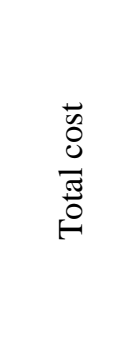 & 弅 & 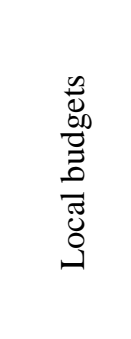 & 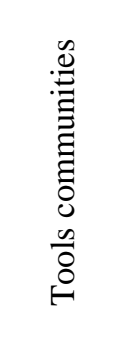 & 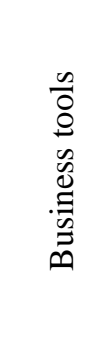 \\
\hline Umansky & 6 & 5 & 5 & 0 & 1 & 919570 & 452376 & 209140 & 168092 & 89962 \\
\hline Gorodyschenskiy & 6 & 5 & 4 & 1 & 1 & 754027 & 377013 & 339312 & 37702 & 0 \\
\hline Zvenigorodsky & 8 & 6 & 2 & 4 & 2 & 1074437 & 544975 & 416332 & 108130 & 5000 \\
\hline Shpolyansky & 9 & 5 & 3 & 6 & 0 & 1258581 & 653259 & 484752 & 65570 & 55000 \\
\hline Chygyrynsky & 8 & 5 & 5 & 2 & 1 & 1134171 & 550645 & 526818 & 56708 & 0 \\
\hline Kanivsky & 6 & 6 & 4 & 2 & 0 & 634086 & 329304 & 272525 & 32257 & 0 \\
\hline Talnivsky & 5 & 5 & 2 & 2 & 1 & 659863 & 322851 & 270914 & 49171 & 16927 \\
\hline Kamiansky & 6 & 5 & 1 & 5 & 0 & 642622 & 339186 & 248317 & 36119 & 19000 \\
\hline Total & 54 & 42 & 26 & 22 & 6 & 7077357 & 3569609 & 2768110 & 553749 & 185889 \\
\hline
\end{tabular}

Four districts (Gorodyshchensky, Drabivskyi Zhashkivskyi and Talne) took part in the experience methodology development, who agreed independently in selected communities to apply the successfully implemented project methodology. The project offered communities a small amount of funds, a maximum of 2000 USD for this initiative and it made up to $20 \%$ of the total project cost, the remaining amount of $5 \%$ had to be allocated to the community and $75 \%$ to provide budgets and sponsors. Only 16 projects were approved on this component, 15 of which successfully presented the report. The total cost of the replicating projects is 1721248.00 UAHof which the EU/UNDP 332955.00 UAH budgets of all levels is 1228 of 839.00 UAH (regional - $120280 \mathrm{UAH}$, district - $2361100 \mathrm{UAH}$, rural - 872449UAH); sponsors - $67650 \mathrm{UAH}$, community funds - $101804 \mathrm{UAH}$.

Thus, the results of participation in phases I and II of the Project EU/UNDP "SPC" in Cherkasy region showed that all initiatives were not only successfully adopted and implemented but it was also possible to fulfill budgetary obligations by consolidating efforts of authorities at the regional level, the districts participating in urban and rural communities.

In the third phase the Project continues to support the traditional areas, in particular energy efficiency, health, environment and water supply in rural areas and also introduced a new component to urban development. The LDC further contributes to the development of small farms and non-farmer business in rural areas. The project supports the Government of Ukraine in development of political principles in the sphere of decentralization and shares innovative approaches and progressive management practices for community participation and local sustainable development with the involvement of communities through knowledge management and training courses in 33 regional universities.

The project EU/UNDP "Local development, oriented on the communities" involves the following specific objectives:promoting the approach to local governance and sustainable 
development focused on the community;increase of energy efficiency at the local level;support to create a database of every separate district, a network for sharing best practices and knowledge on community mobilization and management where the communities can participate.

The project the LDC established cooperation with 24 regions, the 201 districts, 800 rural councils and 25 cities. As of December 31, 2015133 projects in the field of energy efficiency, 351 - saving, 48 - health care, 31 - water and 25 - economic development of rural areas were approved, for a total of 543 projects. More than 1.9 million people in rural communities will feel the benefits from the implementation of the third phase of the project LDC. In addition, almost 57000 inhabitants of cities feel the advantage of the introduction of 206 initiatives to develop urban communities. Based on the methodology of the IWG-III 47 cooperatives were organized. Further studies include the analysis of experience of participation in the subsequent phases of the project and general comparative evaluation of the impact and implications for communities and Ukraine as a whole.

\section{References}

About Draft of IWG.IWG Official site.Avaliable at: http://cba.org.ua/ua/pro-nas/proekt-cba. Annual report on the activities of the MRG Project.Avaliable at: http://cba.org.ua/ua/biblioteka/zviti-proektu.

Berezina, O. Yu., Tkachenko, Yu. V. (2016). Problems of sustainable development of a society: a view of different generations: monograph. National network of University partners of the joint Project EU/UNDP "Local development oriented to the community". Cherkasy State Technological University. Cherkasy: Publisher Yu. A. Chabanenko.

Gazuda, L. M., Rubish, M. A. (2014). Joint investment projects, cross-border cooperation and foreign economic activity of the region. Scientific bulletin of Mukachevo State University.Economics Series. Issue 1 (1), 55-62.

Guides IWG.Avaliable at: http://cba.org.ua/ua/biblioteka/posibniki.

Information on implementation of the CBC European program and partnership instrument in 2007-2013 years. Avaliable at: http://sfs.gov.ua/diyalnist-/mijnarodne-/integratsiya-ukrainido-es/integratsiya-ukraini-do-es/inf_dovidka.

Mikula, N. A., Zasadko, V. V. (2014). Cross-border cooperation of Ukraine in the context of European integration: monograph. Kyiv: NISD. 


\title{
4.5. SUSTAINABLE DEVELOPMENT OF COMMUNITIES ON THE BASIS OF GLOBAL PARTNERSHIP: EVALUATION OF THE RESULTS OF PHASE III OF THE EU/UNDP PROJECT "COMMUNITY BASED APPROACH TO LOCAL DEVELOPMENT"
}

\author{
Yuliia Tkachenko \\ PhD (Economics), Associate Professor, \\ Associate Professorof the Finance Department, \\ Cherkasy State Technological University, Cherkasy, Ukraine
}

The European Union provides financial and technical assistance in the framework of the Ukrainian reform program, implementing their projects in various sectors, regions and cities of Ukraine. Assistance from the EU includes, in particular, supporting democratic progress and effective management, capacity building in administration and infrastructure development. The draft of the LDC as a mechanism for the implementation of local development has been supported since 2008. Beginning with 2015, it was fully aligned with the program of providing a large-scale EU support for the reforms in decentralization, economic development, and the involvement of a civil society. During this time the project spread on more than $80 \%$ of the country and supported local communities in implementing their initiatives. Creating an environment in which local people become active citizens, the UNDP project and the EU distributes sustainable local socio-economic development in Ukraine and trained communities ensure a long-term effect of the project implementation.

The scientific Foundation of the Project EU/UNDP in Ukraine is the work of the National educational network of Universities-partners of the Project, which brings together 35 partners working in the direction of the promotion and implementation of ideas of sustainable development, combined their efforts in training and dissemination of the Project methodology. Institutionalization of educational and scientific cooperation opens up new prospects of implementing the concept of sustainable development in regions, cities and towns throughout Ukraine, which is the prototype of the formation of a unique network of global partnerships. Scientists from Ukraine participating in the National network systematically investigate the prerequisites for the implementation of project initiatives, make a comprehensive analysis of the results and impact of the Project, etc.

A distinctive feature of scientists of the National network of UNIVERSITIES-partners of the Project EU/UNDP "MRG" is the multi-dimensionality of certain problems of sustainable development and interdisciplinary approach to their solution. Therefore, social and governance aspects of the global partnership and their presentation in the framework of the project EU/UNDP are studied by G. Meleganych (2016,2017), A. Shershnyova (2015), et all. The research by G. Mozolievych (2015), Semenenko, I. M., Halgash, R. A., Burco, I. V. (2016) et all made up a powerful scientific platform in the energysaving component. Financial, economic and marketing aspects of sustainable community development are analyzed in the authors' publications (Berezina, O. Yu., Tkachenko, Yu. V., 2015-2018) and publications Yu. Petrushenko, Y. Danko (2014), V. Usyk (2010) et all. The methodological framework of the Project, its presentation and the results were given in publications prepared within the project EU/UNDP "LDC" by the authors Jaysingh Sah, Hendrik van Zyl (Hank), A. Rudich, T. Golovchenko, A. Belyavskaya, S. Slabinska (2013, 2015) and others.

The practical component of the project is implemented initiatives of communities and their experience across Ukraine. During phase I-III of the LDC nearly 3.900 initiatives for local development were supported, among which 1810 projects aimed at rehabilitation of schools and 
kindergartens, 708 projects include health centres, 157 - water systems, 18 - environment, 64 agricultural service cooperatives and 1044 projects in the field of energy saving.It is estimated (according to Annual progress report for 2016) that about 5.6 million people of more than 2830 local administrative units (that is, nearly 20 percent of the total population) received support and benefits in the framework of the LDC Project, starting in 2008, thus the foundation for the successful implementation of decentralization reforms of the government and regional policy was laid.

The third phase of the LDC Project (LDC III) is directly aimed at supporting the Government of Ukraine regarding the implementation of reforms in the sphere of decentralization and local governments in connection with the Disposal of the Government "on local government reform and territorial power organization in Ukraine" from 2014. Technical support, capacity building and financing in the LDC expanded the autonomy and established mechanisms of institutional support of local authorities, and also helped achieve further vertical enhancing of the involvement of communities across the country. The LDC activities were focused on the restoration of basic social and communal infrastructure in priority areas such as energy efficiency, health, environmental protection and water management and the development of agricultural activities in rural, urban and semi-urban areas.

LDC III gave more opportunities in the field of energy efficiency in apartment houses with attraction of citizens concerned for the application of innovative practices on the micro local level. The LDC draft is based on the concept of shared responsibility and joint funding of community development projects. The implementation period of phase III of the LDC Project is 2014-2017 years, the total budget of the project amounts to 23.8 million EUR (23 million EUR provided by the European Union and 800 thousand EURby UNDP in Ukraine). The Project activities of the IWG-III successfully distributed in 24 regions of Ukraine, 201 district and 25 cities. Analyzing of 12 southern, eastern and central regions (Vinnytsya, Dnipropetrovsk, Donetsk, Kharkiv, Kherson, Kirovohrad, Kyiv, Luhansk, Mykolaiv, Odesa, Poltava, Zaporizhia), their high activity and a high rate of involvement of households in the implementation of projects and initiatives should be taken into account. 331070 households, 1885397 community members acted as beneficiaries in Phase III in 12 regions. The largest number was noted in the Luhansk region, at the same time, given the current situation in the East, the ratio of involvement of the population decreased significantly compared to the previous phases. Cherkassy and Poltava regions have significant achievements, the comparative characteristics of which are presented in the study. In Cherkasy region 17328 households, 39497 community members were beneficiaries of the Project, in Poltava accordingly 10437 and 29761 (table. 4.6). The total budget of the micro projects under Phase III was 163.6 thousand UAH. The largest share of the surveyed 12 areas was in Kirovohrad (11.6\% or 18.9 mlnUAH) and Zaporizhia (11.7\% or $19.1 \mathrm{mln} . \mathrm{UAH})$ region. On the whole, Kirovograd and Zaporizhia regions were noted in the third phase as the most active in terms of development and implementation of micro-projects (respectively 47 and 49 grant agreements were signed) and in fund raising. Not only the communities were active in these regions but also a private sector (the share of private sector in MP co-financing amounted to: in the Kirovograd region - $24.7 \%$, in Zaporizhzhya - $32 \%$. It should be noted that Cherkasy and Poltava regions had significan achievements in this aspect: Cherkasy region -47 approved projects and signed grant agreements (in the second place together with Zaporozhia), in Poltava - the greatest share of attracted funds for financing of micro-projects came from the private sector $(35.7 \%$ of total budget). The budget of micro-projects in Cherkasy region amounted to $14.7 \mathrm{mln}$.UAH (9\% of the total budget for 12regions), in Poltava region - $11.0 \mathrm{mln}$.UAH $(6.7 \%)$. The lowest amount of the budget (4.7\%) accounted for Kharkiv region (with UNDP funds and 4.9\%). 
Table 4.6. The beneficiaries of the project EU/UNDP: "LDC-III"

\begin{tabular}{|l|c|c|}
\hline \multirow{2}{*}{ Region } & \multicolumn{2}{|c|}{ Beneficiaries } \\
\cline { 2 - 3 } & Households & Members of the community \\
\hline 1. Cherkasy & 17328 & 39497 \\
\hline 2. Dnepropetrovsk & 17994 & 35343 \\
\hline 3. Donetsk & 56786 & 118463 \\
\hline 4. Kharkiv & 15181 & 37195 \\
\hline 5. Kherson & 12340 & 35109 \\
\hline 6. Kirovohrad & 26139 & 58934 \\
\hline 7. Kiev & 17173 & 33100 \\
\hline 8. Lugansk & 94565 & 1325735 \\
\hline 9. Mykolaiv & 15826 & 46745 \\
\hline 10. Odesa & 22909 & 73560 \\
\hline 11. Poltava & 10437 & 29761 \\
\hline 12. Zaporizhia & 24392 & 51955 \\
\hline Total & 331070 & 1885397 \\
\hline
\end{tabular}

Source: compiled by the author on the basis of data retried from http://cba.org.ua/ua/biblioteka/zviti-proektu

When the common methodology of the project and the principle of co-financing were kept to, the differentiation among the regions on the contributions of the partners and their shares in the financing of micro-projects was evident (table 4.7).

Table 4.7. The beneficiaries of the project EU/UNDP: "LDC-III"

\begin{tabular}{|c|c|c|c|c|c|c|c|c|c|}
\hline \multirow[t]{3}{*}{ Region } & \multicolumn{9}{|c|}{ Budget, UAH. } \\
\hline & \multicolumn{2}{|c|}{$\begin{array}{c}\text { The total } \\
\text { budget for MP }\end{array}$} & \multicolumn{7}{|c|}{ Including partner contributions } \\
\hline & 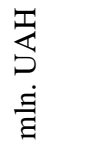 & 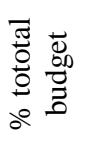 & نூ & $\sum_{\sum}^{\infty}$ & $\sum_{\substack{\searrow \\
\searrow}}^{\searrow}$ & 余 & 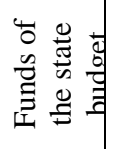 & 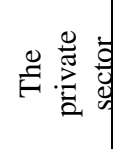 & 令 \\
\hline 1.Cherkasy & 14.7 & 9.0 & 9.3 & 6.8 & 6.4 & 10.8 & 6.8 & 0.0 & 10.1 \\
\hline 2.Dnepropetrovsk & 15.0 & 9.2 & 6.3 & 14.5 & 9.9 & 64.3 & 14.5 & 0.0 & 7.0 \\
\hline 3.Donetsk & 11.0 & 6.7 & 5.9 & 4.2 & 11.7 & 0.0 & 6.9 & 0.0 & 6.8 \\
\hline 4.Kharkiv & 7.6 & 4.7 & 3.3 & 6.7 & 1.4 & 0.0 & 4.5 & 0.0 & 4.9 \\
\hline 5.Kherson & 14.2 & 8.7 & 10.2 & 8.0 & 4.7 & 0.0 & 6.5 & 0.0 & 9.6 \\
\hline 6.Kirovohrad & 18.9 & 11.6 & 17.8 & 10.7 & 9.1 & 1.2 & 9.8 & 24.7 & 11.5 \\
\hline 7.Kiev & 10.5 & 6.4 & 5.5 & 4.6 & 11.0 & 2.2 & 6.9 & 0.0 & 6.3 \\
\hline 8.Lugansk & 13.9 & 8.5 & 6.4 & 7.8 & 9.2 & 16.3 & 8.6 & 0.0 & 8.8 \\
\hline 9.Mykolaiv & 15.7 & 9.6 & 11.2 & 7.5 & 12.4 & 3.7 & 9.2 & 6.3 & 9.6 \\
\hline 10.Odesa & 12.0 & 7.3 & 8.8 & 5.2 & 4.6 & 0.0 & 4.8 & 1.3 & 8.4 \\
\hline 11.Poltava & 11.0 & 6.7 & 4.3 & 7.2 & 8.1 & 0.0 & 7.3 & 35.7 & 6.5 \\
\hline 12.Zaporizhia & 19.1 & 11.7 & 10.9 & 16.8 & 11.3 & 1.5 & 14.2 & 32.0 & 10.4 \\
\hline Total & 163,6 & 100 & 100 & 100 & 100 & 100 & 100 & 100 & 100 \\
\hline
\end{tabular}


In the structure of the general budget of Cherkasy region (14.7 mln.UAH in Phase III) the largest share was accounted for by the region state administration / region council (10.8 $\%)$. The share of UNDP (10.1\%) was also significant. The share of collected by community funds amounted to $9.3 \%$, theprivate sector was not involved (Fig. 4.13). The share of UNDP funding in the Poltava region was $59.6 \%$ in Phase III, state budget funds $-32.9 \%$ However, the proportion of communities was small $-5 \%$.

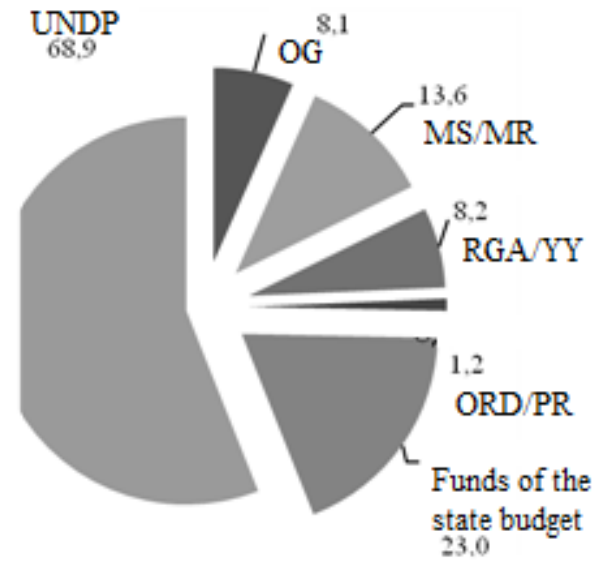

a) Cherkasy region

b) Poltava region
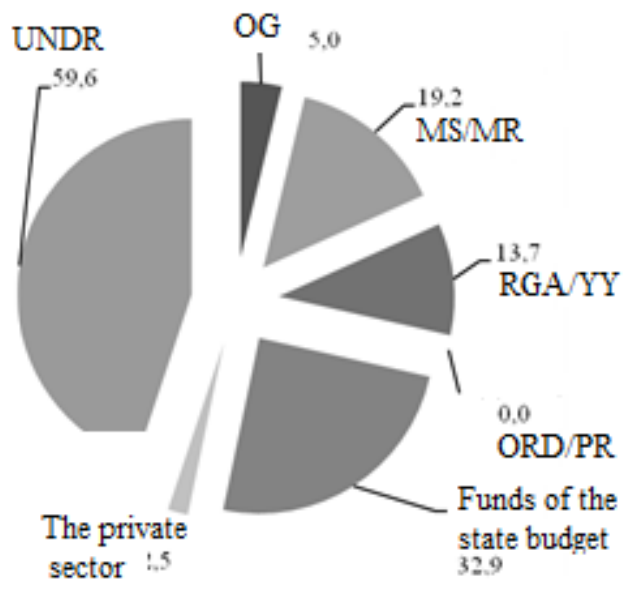

Figure 4. 13. The structure of the micro-project budgets in Cherkasy and Poltava regions Source: compiled by the author on the basis of data retried from http://cba.org.ua/ua/biblioteka/zviti-proektu

Berezina O.Yu (2016) noted that in the third phase of the Project the micro-projects of local priorities for improvement of basic services, social, economic, infrastructure or health were implemented. Support of infrastructure includes three types of micro-projects, depending on the shape of the distribution of contributions: micro projects of a basic type, micro projects with the methodology and efficiency use. In micro projects of the basic type (according to Annual progress report for 2016) the organization's contribution shall be 5\% of the total budget, the contribution of local, district or regional budget $-20 \%$ from the LDC project $-75 \%$. In micro projects with the methodology application 5\% of the total amount is provided by the OG, 30\% - from the local budget and 65\% of the LCD Project. Financing of micro-projects on energy efficiency was distributed as follows: $5 \%$ of OG, $20 \%$ - from the local budget and $75 \%$ of the LDC Project.

In the third phase of the Project the greatest number of implemented micro-projects was observed in infrastructure component (320), in particular in the field of energy saving 271 micro project $(84.7 \%$ of the total amount of the implemented infrasturture projects). The least implemented initiatives were the ones concerning the environment $(0.3 \%)$ and health (6.3 percent). On the regional level there was the following situation according to the project components: the greater part of the infrastructure micro-projects was approved and implemented in Dnipropetrovsk (31), Zaporizhzhya (29) and Luhansk (29). According to the overall trends in Ukraine, the vast majority of micro-projects was implemented in the field of energy conservation (table. 4.8). 
Table 4.8 Typology of microprojects for the Project activity

\begin{tabular}{|c|c|c|c|c|c|c|c|c|}
\hline \multirow[b]{2}{*}{ Region } & \multirow[b]{2}{*}{ 吾 } & \multicolumn{4}{|c|}{ Infrastructure MP, including: } & \multirow[b]{2}{*}{ 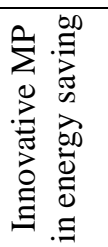 } & \multirow[b]{2}{*}{ 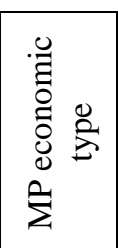 } & \multirow[t]{2}{*}{ Total } \\
\hline & & 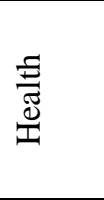 & 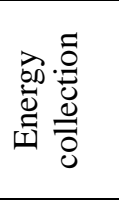 & 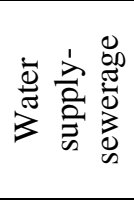 & 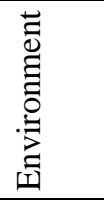 & & & \\
\hline 1.Cherkasy & 27 & 2 & 21 & 4 & 0 & 10 & 10 & 47 \\
\hline 2.Dnepropetrovsk & 31 & 0 & 30 & 1 & 0 & 8 & 0 & 39 \\
\hline 3.Donetsk & 28 & 6 & 21 & 1 & 0 & 3 & 1 & 32 \\
\hline 4.Kharkiv & 25 & 2 & 23 & 0 & 0 & 6 & 0 & 31 \\
\hline 5.Kherson & 25 & 0 & 23 & 2 & 0 & 8 & 10 & 43 \\
\hline 6.Kirovohrad & 28 & 0 & 27 & 1 & 0 & 10 & 11 & 49 \\
\hline 7.Kiev & 22 & 0 & 19 & 3 & 0 & 9 & 0 & 31 \\
\hline 8.Lugansk & 29 & 6 & 18 & 4 & 1 & 9 & 0 & 38 \\
\hline 9.Mykolaiv & 24 & 0 & 20 & 4 & 0 & 13 & 7 & 44 \\
\hline 10.Odesa & 26 & 3 & 20 & 3 & 0 & 7 & 6 & 39 \\
\hline 11.Poltava & 26 & 1 & 23 & 2 & 0 & 7 & 0 & 33 \\
\hline 12.Zaporizhia & 29 & 0 & 26 & 3 & 0 & 10 & 8 & 47 \\
\hline Total & 320 & 20 & 271 & 28 & 1 & 100 & 53 & 473 \\
\hline Total \% & $100.0 \%$ & $6.3 \%$ & $84.7 \%$ & $8.8 \%$ & $0.3 \%$ & & & \\
\hline Total \% & & $4.2 \%$ & $57.3 \%$ & $5.9 \%$ & $0.2 \%$ & $21.1 \%$ & $11.2 \%$ & $100.0 \%$ \\
\hline
\end{tabular}

In Cherkasy in the third Phase, implemented 27 infrastructure micro-projects (57.4\% of the total number of micro-projects), including in the field of energy efficiency -21 , water and sanitation -4 , health -2 . The high activity of communities in the implementation of energy saving innovations (10 micro-projects (10\% of the total number of MP in this component)) and economic component (10 micro-projects $(18,9 \%$ of the total number of MP in this component)) should be noted.

In Poltava region, which is under Phase III 33 projects were implemented, their largest number is concentrated in the infrastructure component (26 MP) in the field of energy saving (23 MP). Also in Poltava region 7 innovative micro projects in energy savings ( $7 \%$ of the total number of MP in this component) are implemented.

The budget of micro-projects was distributed as follows: infrastructure micro-projects 73.9 millionUAH (45\% of total funding), innovative micro-projects in energy efficiency -36 million UAH (22\%), replicated (replicated) micro - 29 million UAH (18\%) and economic micro-projects - 24.7 million UAH (15\%), Fig. 4.14.

Thus, the project of the LDC-III aims at the inclusion of the approach-oriented development community, the work of local authorities. Given this, the Project focuses on the support of the methodology providing an enhanced role of the government in the processes of community mobilization and reduction of the share of the LDC in the total cost of the micro project communities.

In addition, district and regional authorities interested in applying the Project's methodology in other regions/areas are also provided with the appropriate technical support. In the framework of Phase III of the project EU/UNDP "Local development, oriented on the communities" there are certain achievements in all regions of Ukraine, which proves the 
universality of the methodology of the Project and its effectiveness in all areas. Cherkasy and Poltava regions were nored in the third phase for their enhanced activity and characteristics of implementation of innovative projects in energy conservation.

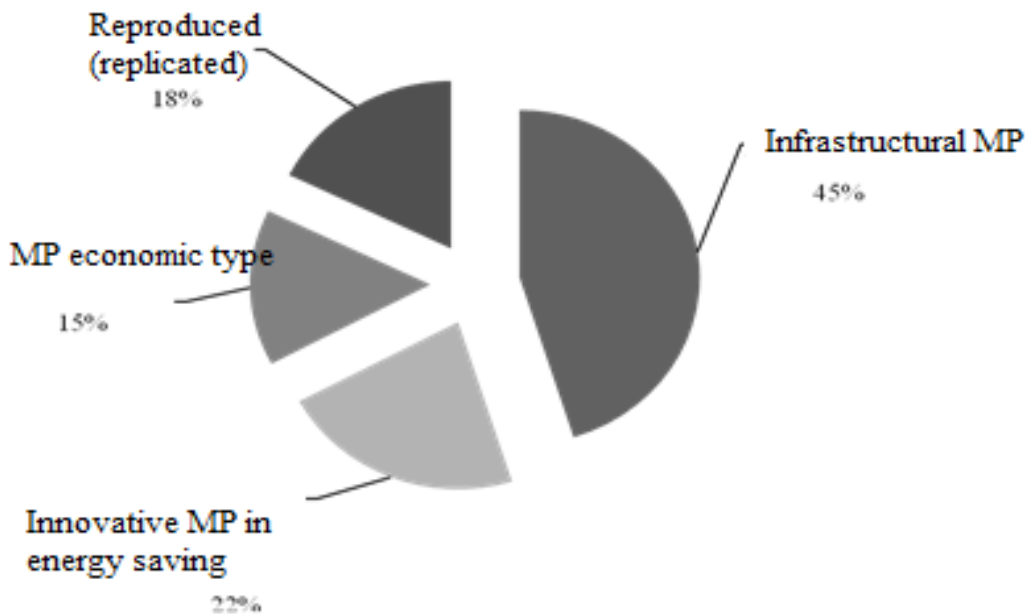

Figure 4.14. The structure of the Project budget components

Source: compiled by the author on the basis of data retried from http://cba.org.ua/ua/biblioteka/zviti-proektu

To sum up, it should be noted that the key components of the LDC -III program focus on the development of partnerships to achieve meaningful results for sustainable development on the whole territory of the country. This means developing priority plans together with the communities, proposals for projects initiated by the community, approval of micro-projects and their financing, as well as ongoing monitoring of implementation to ensure maximum transparency and accountability.

Initiating activities in the field of regional development and attracting companies helps get unique designs extremely important for society. While the LDC provides technical support in the framework of this process, the actual participation of each government structure provides an opportunity not only to expand the capacity of communities and local authorities. LDC Methodology is aimed to strengthen the capacity of communities, which is a strong foundation and the success of the decentralization reform. Close relationship plays the role of a Project catalyst in the reform implementation and it was developed between the LDC community-partners and voluntary decision of rural and urban councils on the formation of unified territorial communities.

\section{References:}

About Draft of IWG.IWG Official site.Avaliable at: http://cba.org.ua/ua/pro-nas/proekt-cba. Annual progress report for 2016. Local development oriented on community. Phase III. Avaliable at: http://cba.org.ua/images/APRs/170721_1817_CBA_2017.pdf.

Annual report on the activities of the MRG Project Avaliable at: http://cba.org.ua/ua/biblioteka/zviti-proektu. 
Annual report on the activities of the MRG Project.Avaliable at: http://cba.org.ua/ua/biblioteka/zviti-proektu.

Berezina O. Yu.(2015) The goal of sustainable development and the strategic vectors of social reforms in Ukraine.Avaliable

at: http://eztuir.ztu.edu.ua/jspui/bitstream/123456789/5560/1/151.pdf.

Berezina, O. Yu., Tkachenko, Yu. V. (2016). Problems of sustainable development of a society: a view of different generations: monograph. National network of University partners of the joint Project EU/UNDP "Local development oriented to the community". Cherkasy State Technological University. Cherkasy: Publisher Yu. A. Chabanenko.

Energy audits and energy management in sustainable development projects : Handbook. Avaliable at: http://cba.org.ua/images/MANUALS/EE_manual.pdf

Guides IWG. Avaliable at: http://cba.org.ua/ua/biblioteka/posibniki.

Information and culture in a sustainable human development: proceedings of the international scientific and practical conf., Mariupol, Novemeber 04, 2015. Mariupol State University; ed. by G.I. Batychko. Mariupol: $M D U$.

Mozolevich, G. (2015). Information on implementation of the CBC European program and partnership instrument in 2007-2013 years. Avaliable at: http://sfs.gov.ua/diyalnist/mijnarodne-/integratsiya-ukraini-do-es/integratsiya-ukraini-do-es/inf_dovidka.

Meleganych, H. (2017). The role and importance of the Ukrainian-Slovak cross-border cooperation for sustainable development of the border communities in the Transcarpathian region. K inovacii slovensko-ukrajinskej cezhraničnej spolupráce.- Centrum spolocenskych a psychologickych vied SAV, Košice.

Meleganych, H. I., Petrushenko, Yu. M. (2016).Local development with the community involvement. Volume 4: Regional aspects of sustainable urban development: monograph. Kiev: WAITE.

Mikula, N. A., Zasadko, V. V. (2014). Cross-border cooperation of Ukraine in the context of European integration: monograph. Kyiv: NISD.

Petrushenko, Yu. M. (2013). Local development with community involvement [Text] : monograph: in 2 volumes Vol. 2 : Institutional and practical aspects of the management of local development-oriented society. Sumy: University book.

Petrushenko, Yu. M., Kostyuchenko, N. M., Danko, Yu. I. (2014).The conceptual basis for financing of local development projects of the UN development programme in Ukraine.Actual problems of economy. No. 9, 257-263.

Semenenko, I. M., Halgash, R. A., Burco I. V. (2016). The energy supply of Ukrainian regions in the context of sustainable development. Bulletin of East Ukrainian National University named after Volodymyr Dahl. No. 6, 124-134. Avaliable at: http://nbuv.gov.ua/UJRN/VSUNU_2016_6_24

Usyk, V. I., H. V. Gyrenko K. V. (2010). Budget participation as an effective tool of local selfgovernment Avaliable at: http://ir.kneu.edu.ua:8080/handle/2010/21119. 


\title{
CHAPTER 5
}

\section{ENVIRONMENTAL, ENERGY AND INNOVATION COMPONENTS OF THE GLOBAL PARTNERSHIP FOR SUSTAINABLE DEVELOPMENT}

\subsection{TECHNICAL AND TECHNOLOGICAL BASES FOR ACHIEVING ENVIRONMENTAL SAFETY OF SUSTAINABLE DEVELOPMENT}

\author{
VolodimirTychkov \\ PhD (Technical Science),
}

Senior Lecturerof theDepartment of Computerized and Informatized Technologies of Instrumentation, Cherkasy State Technological University, Cherkasy, Ukraine

\section{VolodimirGalchenko}

Doctor of Technical Sciences, Professor,

Professor of the Department of Computerized and Informatized Technologies

of Instrumentation, Cherkasy State Technological University, Cherkasy, Ukraine

\section{Ruslana Trembovetskaya}

PhD (Technical Science), Associate Professor,

Associate Professor of the Department of Computerized and Informatized Technologies

of Instrumentation, Cherkasy State Technological University, Cherkasy, Ukraine

One of the sustainable development (SD) components is the ecology in terms of biological and physical natural system integrity ensuring. However, in the sustainable development theory, the technological and technical SD environmental safety components are not considered. The technological component ensures the manufacturing technologies reliability for high-quality products on the one hand, and on the other hand, qualitative technology waste: air emissions and hydrosphere discharges. In most cases, due to imperfections of the technological processes themselves, it is impossible to ensure environmental safety of the environment. From a technical view point, we understand the measuring instruments improvement, monitoring the harmful substances content at all technological production stages. The most important such production technological parameter is the processed materials composition, therefore the measuring analytical control is an obligatory element of any automatic process water control system, which is carried out directly in the production stream. By the term water for technological purposes (or process water) we mean water that is used to provide the technological process at all production and operation stages of the enterprise as a whole and directly contacts raw materials and intermediates in the technological process: from selection, washing and use in the process itself and ending with aqueous solutions forming wastewater. The process water quality is determined by the complex of its chemical components and physical properties that determine the suitability of water for certain types of water using. The main factors that affect the environmental safety quality of the technological process include the water composition, pressure and temperature in process units, aggregates and others.

Technical means of environmental industrial type safety control, in contrast to laboratory measuring instruments, operate continuously, without the operator's participation, often under less favorable conditions and at the maximum permissible metrological characteristics, with a high content of substances in the analyzed technological solutions. Therefore, operations such as zeroing and checking the measuring device scale calibration 
must be performed automatically. We agree with Otto M. (2008), Cammann. K. (2012) that the industrial analyzer output signal must depend in a known way on the process solution composition and be designed to connect the recording device, regulator or computer. To the technical and technological basis for achieving environmental safety, several ways of using ion-selective electrodes in devices for continuous technological control can be attributed.

The scheme of a continuous potentiometric measurement of ion activity in a flow using a flow-through primary sensor with an ion-selective electrode and a reference electrode was demonstrated in Fig. 5.1. The measured solution or part of it continuously flushes the electrodes. The electrodes leads and the temperature compensator are connected to the converter, which gives a signal to the recording and regulating devices. Such a scheme is applicable to solutions in which there are no ions that interfere with measurements with ionselective electrodes (process water). Such schemes are well recommended for $\mathrm{pH}$ measurement in various industrial and waste solutions.

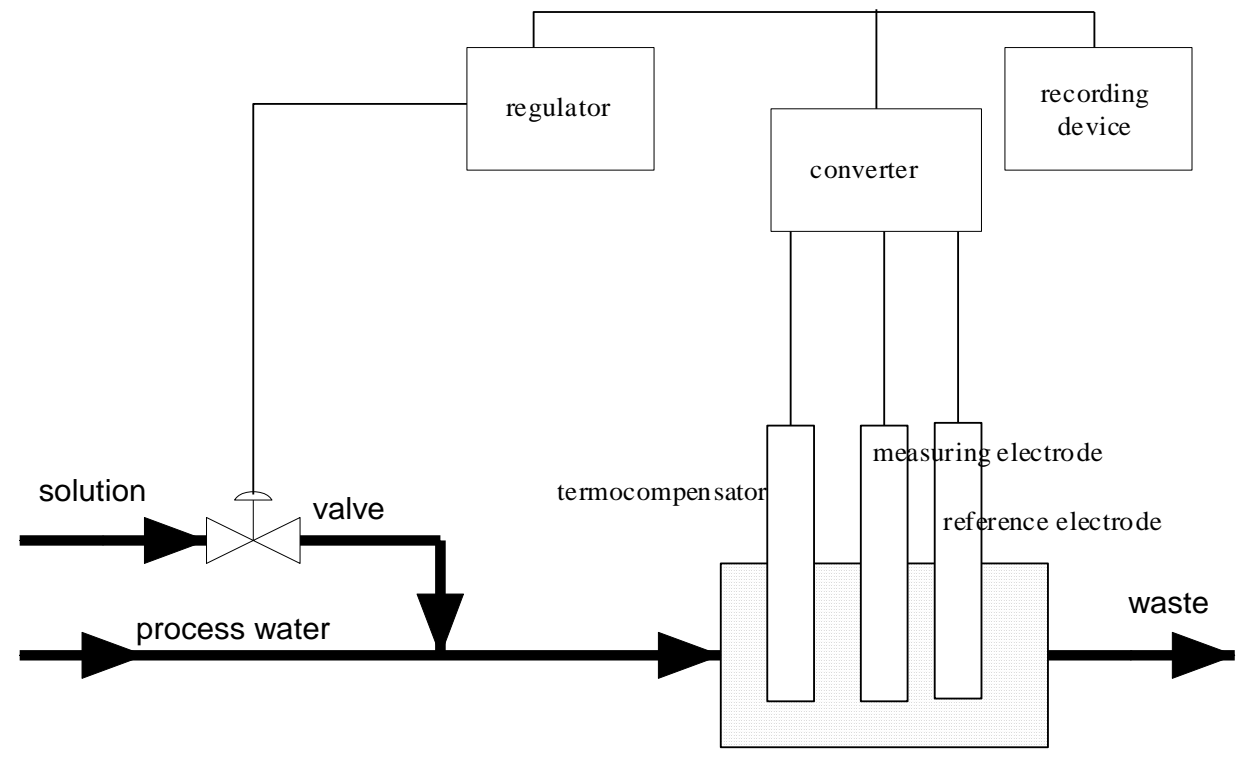

Figure 5.1. Measuring and controlling method for a process using an ion-selective electrode

Source: developed by the authors

However, it is possible to use a combined measuring primary sensor in one housing instead of termocompensator, measuring and reference electrodes, which makes it possible to simplify and improve the technological equipment and to ensure high accuracy of measurement and regulation, which entails an increase in the SD environmental safety.

The second method for the continuous determination of the ion content can be the principle of a symmetrical element, so the results of measurements at an isotopic point corresponding to the ion concentration are temperature independent (Fig. 5.2). This is achieved by filling both the measuring electrode and the comparative electrode with a solution of the same composition. In this case, the measuring instrument should show 0 on the digital display. 


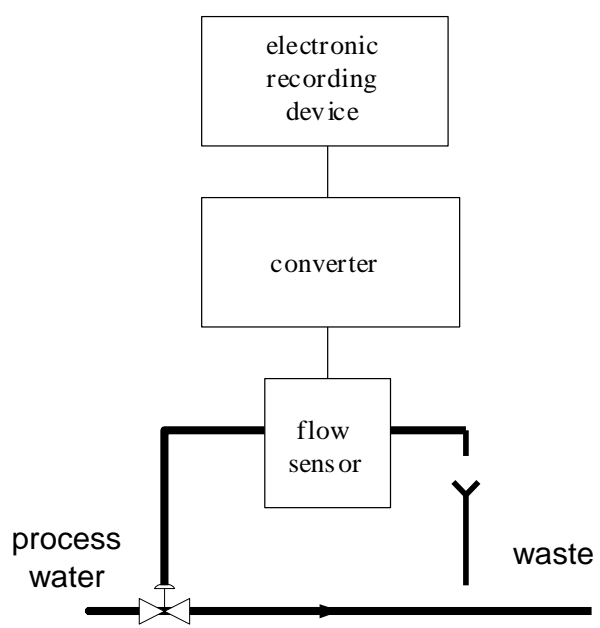

Figure 5.2. Continuous measurement method of ion content in process water Source: developed by the authors

The measurement method using a combined flow type sensor with several ion selective electrodesis described in Fig.5.3. Such a sensor can be used to simultaneously measure the different ions activity or to make appropriate corrections to the readings of one of the electrodes.

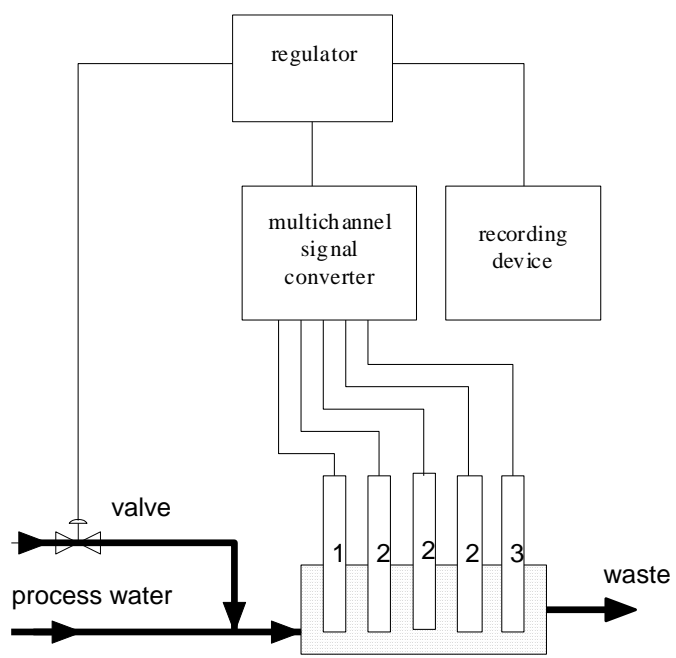

Figure 5.3. Measuring process control method of using several ion-selective electrodes: 1-thermocompensator; 2-ion-selective electrodes; 3-reference electrode Source: developed by the authors

The method for introducing corrections into the indications of ion-selective electrodes having incomplete a specific ion selectivityshows in Fig. 5.4. This method involves the addition of a specific reagent to the process solution stream before this solution is analyzed by an ion-selective electrode. For example, $\mathrm{pH}$ constantly limits the use of an ion-selective electrode. The introduction of an appropriate buffer solution in such an amount that there was no significant dilution of the sample will allow the application of many electrodes to be 
expanded. The flow ratio controller used to maintain a specific ratio of the reagent and solution flow rates, measured individually by flowmeters (Fig. 5.4).

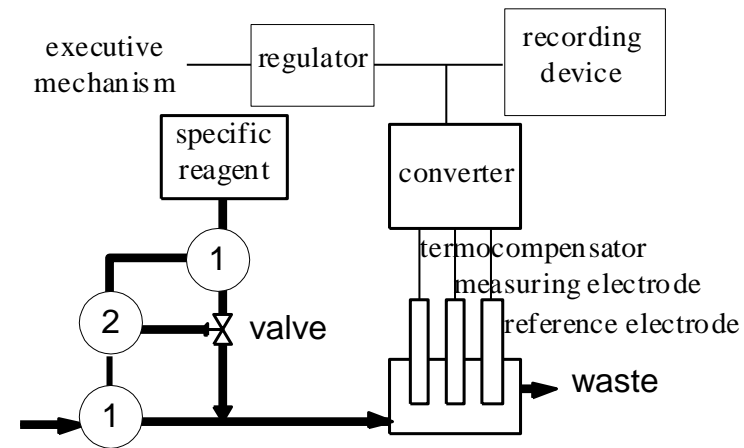

Figure 5.4. Measuring control method with the reagent addition

Source: developed by the authors

The main shortcoming of these methods of measuring control can be attributed to the complexity of technical implementation to ensure SD environmental safety. With the using of measurement control injection methods, it is possible to achieve acceptable accuracy, reliability and most importantly technological processes environmental safety.

The method of injection analysis using ultrasonic sample preparation was used at the authors' works (Tychkov, V. V.,2015, 2017) to increase the measuring control accuracy of the technological processes environmental safety.

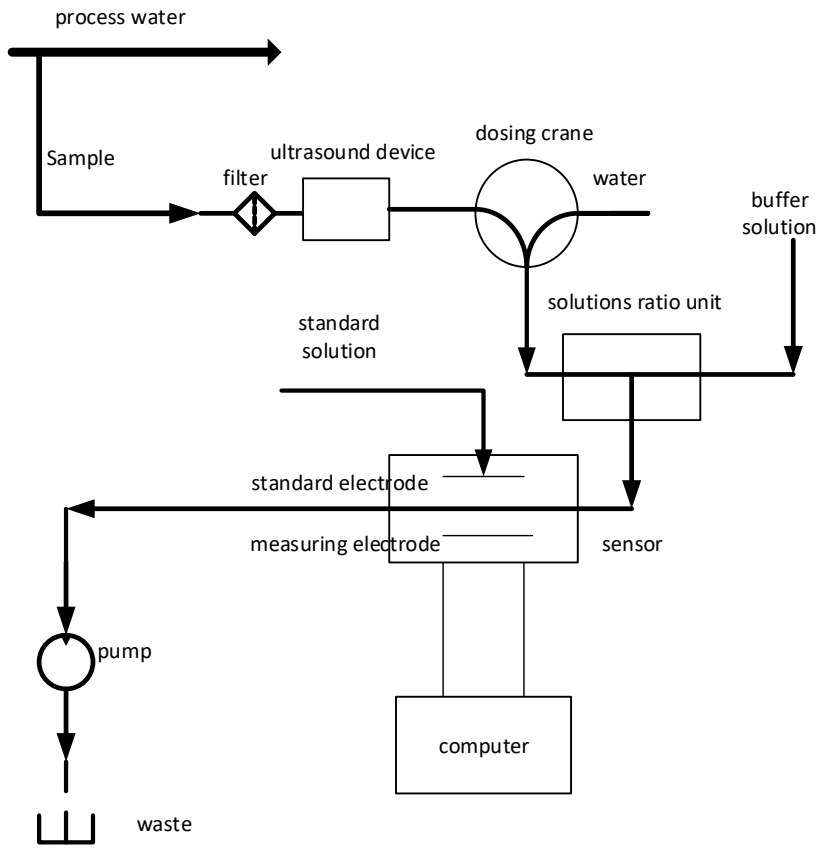

Figure 5.5. Measuring control injection method with a flow-through slot sensor based on solid-state heterogeneous ion-selective electrodes

Source: developed by the authors 
In the measuring control injection method (Fig. 4.5), in addition to the measurements in the flow-through slot sensor, the sample in the stream filtration prior to the ultrasonic sampling preparation is additionally carried out.

As a container with a standard solution of a detectable element, a capacity with a standard solution with a maximum permissible concentration or its multiple value of the detectable element can be used. An electromagnetic valve can be used as a two-way dosing crane. A solutions ratio unit with a different ratio of sample solution and buffer solution, which can be adjusted in length, height and width, or the shape of the cross-section plane of the duct channel, can be used as the solution ratio nodes. As a sensor, electrochemical flowthrough slot sensors and their combination can be used. As a pump, a peristaltic or electromagnetic pump may be used, or can be made as a syringe pump. As an auxiliary measuring device, a computer, a recorder can be used. The computer (microcontroller, microprocessor) can be used as a control unit for the operation of the ultrasonic sample preparation unit, the two-way crane, the pump and perform the information removal, data processing and experiment optimization the from the flow-through slot sensor and information display on the screen or on the recorder with printing and documentation measurements.

The method is as follows. Through a filter and an ultrasonic sample preparation unit, a two-way dosing crane, the ratio of solutions to the reaction mixer through a pump is fed sequentially to the sample. For this purpose, the two-way dosing crane gradually makes the connection of the hydraulic line formed by the channel of the multi-crane and the sensor, with its inputs, one of which is a sample. To ensure sample mixing and the buffer solution, as well as to ensure the reaction response, one of the channels solutions ratio unit is coupled to a capacity with a buffer solution, which is inert to the sample. For washing with distilled water, the two-way dosing crane is brought to a condition where the hydraulic line formed by the channel of the two-way dosing crane and the sensor, connected to this channel, distilled water with a buffer solution is pumped through the reaction mixer. After the reaction is completed in the reaction mixer, the reaction products pass through the sensor to the waste. For this purpose, one of the channels of the two-way dosing crane is used both as a flushing and connected with a drainage vessel. The sensor makes measurements (logs an analytical signal), based on which data is computed result, for example, by processing information made in the form of a computer. In case of long measurements need (for example, in the reactions kinetics study), it is possible to stop the pump at the time of measurements.

A plan is presented for an active experiment on the temperature and sample concentration effect on the potential of a measuring electrode using a two-parameter regression analysis.

The temperature range in the calculations was $20-45^{\circ} \mathrm{C}$. The temperature in standard electrode cell was set equal to $25^{\circ} \mathrm{C}$. The concentration of the standard solution was applied at the level of 10-3 M. The concentration measuring sample change was 10-1-10-6 M.

The calculated equation for the two-parameter regression analysis is presented:

$$
\mathrm{U}_{\mathrm{i}}:=\mathrm{Bt} \cdot \log (\mathrm{Cm})-\mathrm{B}_{\mathrm{i}} \cdot \log \left(\mathrm{Cs}_{\mathrm{i}}\right)-\mathrm{K}
$$

where

$$
\mathrm{Bt}:=\frac{2.3 \mathrm{R} \cdot \mathrm{Tt}}{\mathrm{z} \cdot \mathrm{F}} \quad \text { slope }
$$




\begin{tabular}{|c|c|}
\hline $\mathrm{R}:=8.31445 \quad \mathrm{~J} / \mathrm{mol} \cdot \mathrm{K}$ & universal gas constant \\
\hline $\mathrm{Tt}:=298.1{ }_{\mathrm{K}}$ & standard solution temperature \\
\hline $\mathrm{z}:=1$ & measured ion valence \\
\hline $\mathrm{F}:=96.485332 \varepsilon \mathrm{C} / \mathrm{mol}$ & Faraday's number \\
\hline $\mathrm{Cm}:=0.41988$ & standard solution concentration \\
\hline $\mathrm{B}_{\mathrm{i}}:=\frac{2.3 \mathrm{R} \cdot \mathrm{T}_{\mathrm{i}}}{\mathrm{z} \cdot \mathrm{F}}$ & slope with changing temperature \\
\hline $\mathrm{T}_{\mathrm{i}}:=$ & $\mathrm{Cs}_{\mathrm{i}}:=$ \\
\hline 293.15 & 41.988 \\
\hline 298.15 & 4.1988 \\
\hline 303.15 & 0.41988 \\
\hline 308.15 & 0.041988 \\
\hline 313.15 & 0.0041988 \\
\hline 318.15 temperature change & $\overline{0.0004198 \varepsilon}$ concentration change \\
\hline $\mathrm{K}:=\frac{\mathrm{I} \cdot \mathrm{Re}}{\mathrm{S}}$ & sensor constant \\
\hline $\mathrm{I}:=10^{-9} \mathrm{~A} / \mathrm{cm}^{2}$ & ox-red reaction current \\
\hline $\operatorname{Re}:=1.610^{6} \mathrm{Om}$ & sensor resistance \\
\hline$S:=0.0 \varepsilon_{\mathrm{cm}^{2}}$ & sensor surface area \\
\hline
\end{tabular}

The relative error in the computational experiment design and the measured values of the measuring electrode potential did not exceed $2 \%$.

The covariance matrix (Tab. 5.1) is given in $n x n$ form, where $n$ is the number of parameters. The fist row corresponds - thefirst parameter, the second row to the second parameter, and so on. The covariance matrix gives further information about the relation between the model parameters and their uncertainties. The entries along the diagonal are directly related to the uncertainty in each parameter.

Table 5.1. Covariance matrix

\begin{tabular}{|c|c|c|c|}
\hline 93041.437 & -10.426749 & -46524.61 & -8.5550483 \\
\hline-10.426749 & 0.0021919455 & 4.3796262 & 0.00088289081 \\
\hline-46524.61 & 4.3796262 & 23944.718 & 4.3396078 \\
\hline-8.5550483 & 0.00088289081 & 4.3396078 & 0.00079233911 \\
\hline
\end{tabular}

Source: developed by the authors

The covariance matrix can be used in further statistical analysis of the regression model (Fig. 5.6) and its goodness-of-fit.

Linear regression completed successfully. No weighting used. The parameters for the above model equation are given to the right in the coefficient list (Tab.5 2). The iteration count of 100 was exceeded. The fil failed to converge to tolerance of 0,0000001 . 


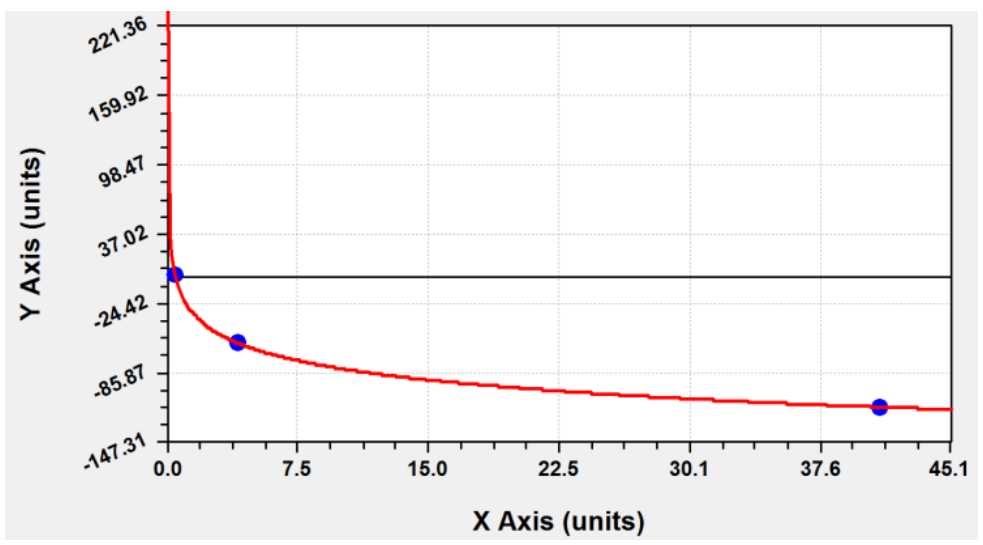

Figure 5.6. Mathematical model of the temperature and concentration influence on the Source: developed by the authors measuring electrode potential

The residual plot (Fig. 5.7) graphically depicts the difference between the data points and the model evaluated at the data points. The residual at point $i$ is defined by:

residual $=y_{i}-f\left(x_{i}\right)$

where $y_{i}-$ themeasured value at $x_{i ;} ;\left(x_{i}\right)$ - thepredicted value at $x_{i}$.

These distances are shown as bars or points on the residual plot; the magnitudes of the data points are simply replaced by the residual defined above. If the residual is positive, then the data point is above the model's prediction; likewise, if the residual is negative, then the data point is below the model's prediction. The residuals can provide an indication of a particular model's performance. If there are runs of like-signed residuals, then a better model for the data is likely to exist. Optimally, the residuals should exhibit a random scatter around zero, which indicates that the data points are randomly distributed around the curve. A "run" is a sequence of like-signed residuals, which stand out on the residual plot. A large number of runs indicates that data systematically deviates from the curve.

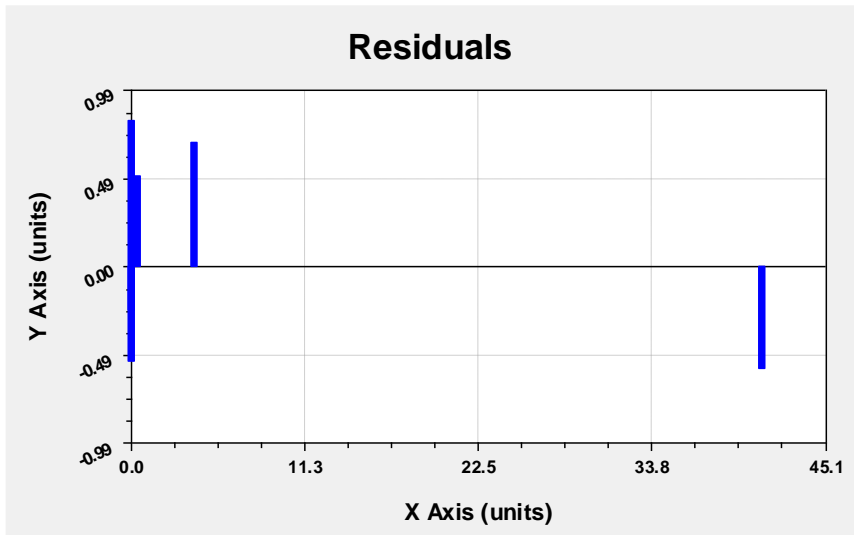

Figure 5.7. Residuals of the mathematical model

Source: developed by the authors 
Table 5.2. Mathematical models of the temperature and concentration influence on the measuring electrode potential ranked by the standard error

\begin{tabular}{|c|c|c|l|c|}
\hline Rank & Regression & Model & Coefficient Data & Standard Error \\
\hline \multirow{2}{*}{1} & $\begin{array}{c}\text { MMF } \\
\text { Model }\end{array}$ & $y=\frac{a b+c x^{d}}{b+x^{d}}$ & $\begin{array}{l}\mathrm{a}=809.46222 \\
\mathrm{~b}=0.5957931\end{array}$ & $\begin{array}{l}\mathrm{c}=-519.95087 \\
\mathrm{~d}=0.0838078\end{array}$ \\
\hline 2 & $\begin{array}{c}\text { Logarithm } \\
\text { Fit }\end{array}$ & $y=a+b \ln x$ & $\begin{array}{l}\mathrm{a}=-20.796137 \\
\mathrm{~b}=-26.68578\end{array}$ & 3.02 \\
\hline
\end{tabular}

Source: developed by the authors

For graphical study of the relief of a two variables function, the function values on a rectangular grid were calculated in advance, i.e. built a table of function values. To do this, we set the following parameters:

$$
\begin{aligned}
& f(x, y):=\frac{2.3 R \cdot T t}{z \cdot F} \cdot \log (C m)-\frac{2.3 R \cdot x}{z \cdot F} \cdot \log (y)-K \quad \text { function of two variables } \\
& N:=2 \mathrm{C} \\
& \mathrm{hx}:=1.2 \leqslant \mathrm{hy}:=2 . \varepsilon \\
& \mathrm{xn}:=293.1 . \mathrm{yn}:=0.000419 \varepsilon \\
& \mathrm{i}:=0 . . \mathrm{Nj}:=0 . . \mathrm{N} \\
& x_{i}:=x n+h x \cdot j y_{j}:=y n+h y \cdot j \\
& z_{i, j}:=f\left(x_{i}, y_{j}\right) \\
& \text { number of grid nodes in the } \mathrm{x} \text { and } \mathrm{y} \\
& \text { plane } \\
& \text { steps for variables } \mathrm{x} \text { and } \mathrm{y} \text { respectively } \\
& \text { initial values of variables } x \text { and } y \text {, } \\
& \text { respectively, when constructing a grid } \\
& \text { determining the range of change of } \\
& \text { integer indexes of grid nodes } \\
& \text { determining the coordinates of grid } \\
& \text { nodes } \\
& \text { constructing the matrix applicat in the } \\
& \text { grid nodes }
\end{aligned}
$$

The 20x20 matrix applicat (Fig. 5.8) represents the two-parameter regression analysis result of a computational experiment with step-by-step calculation of the temperature and concentration changes effect of harmful substances on the measuring electrode potential.

Based on the obtained mathematical modeling data $f$ the measurement process with a high error, it is possible to analyze the uncertainty degree of the external factors influence on the final result of the measuring analytical process water control (Tychkov V. V., 2016, 2017). Thanks to these data it is possible to assess the degree of technical and technological component of the ecological safety of sustainable development.

The authors proposed to apply a one-parameter and multiparameter regression analysis for solving optimization problems.

Summarizing the above, we presents the technical and technological bases of the ecological safety of sustainable development. Technical methods of implementation of measuring analytical harmful substances in process water control are proposed.A twoparameter regression analysis is proposed for mathematical modeling of decision making in the context of a computational experiment in measuring control using ion-selective electrodes. 


\begin{tabular}{|c|c|c|c|c|c|c|c|}
\hline & 0 & 1 & 2 & 3 & 4 & 5 & 6 \\
\hline 0 & 173.913 & -48.275 & -65.763 & -75.994 & -83.253 & -88.883 & -93.484 \\
\hline 1 & 174.749 & -48.386 & -65.949 & -76.223 & -83.513 & -89.167 & -93.787 \\
\hline 2 & 175.586 & -48.496 & -66.134 & -76.452 & -83.773 & -89.451 & -94.091 \\
\hline 3 & 176.423 & -48.607 & -66.319 & -76.681 & -84.033 & -89.735 & -94.394 \\
\hline 4 & 177.259 & -48.718 & -66.505 & -76.91 & -84.293 & -90.019 & -94.698 \\
\hline 5 & 178.096 & -48.829 & -66.69 & -77.139 & -84.552 & -90.303 & -95.001 \\
\hline 6 & 178.932 & -48.94 & -66.875 & -77.368 & -84.812 & -90.587 & -95.305 \\
\hline 7 & 179.769 & -49.05 & -67.061 & -77.597 & -85.072 & -90.871 & -95.609 \\
\hline 8 & 180.606 & -49.161 & -67.246 & -77.826 & -85.332 & -91.155 & -95.912 \\
\hline 9 & 181.442 & -49.272 & -67.432 & -78.055 & -85.592 & -91.439 & -96.216 \\
\hline 10 & 182.279 & -49.383 & -67.617 & -78.284 & -85.852 & -91.723 & -96.519 \\
\hline 11 & 183.115 & -49.494 & -67.802 & -78.513 & -86.112 & -92.007 & -96.823 \\
\hline 12 & 183.952 & -49.604 & -67.988 & -78.742 & -86.372 & -92.291 & -97.126 \\
\hline 13 & 184.789 & -49.715 & -68.173 & -78.971 & -86.632 & -92.575 & -97.43 \\
\hline 14 & 185.625 & -49.826 & -68.358 & -79.2 & -86.892 & -92.859 & -97.734 \\
\hline 15 & 186.462 & -49.937 & -68.544 & -79.429 & -87.152 & -93.143 & -98.037 \\
\hline 16 & 187.299 & -50.048 & -68.729 & -79.658 & -87.412 & -93.426 & -98.341 \\
\hline 17 & 188.135 & -50.158 & -68.915 & -79.887 & -87.672 & -93.71 & -98.644 \\
\hline 18 & 188.972 & -50.269 & -69.1 & -80.116 & -87.932 & -93.994 & -98.948 \\
\hline 19 & 189.808 & -50.38 & -69.285 & -80.345 & -88.192 & -94.278 & -99.251 \\
\hline 20 & 190.645 & -50.491 & -69.471 & -80.574 & -88.452 & -94.562 & -99.555 \\
\hline
\end{tabular}

Figure 5.8. Matrix applicat in the grid nodes

Source: developed by the authors

\begin{tabular}{|c|c|c|c|c|c|c|c|}
\hline & 7 & 8 & 9 & 10 & 11 & 12 & 13 \\
\hline 0 & -97.373 & -100.743 & -103.715 & -106.373 & -108.778 & -110.974 & -112.993 \\
\hline 1 & -97.693 & -101.077 & -104.062 & -106.732 & -109.147 & -111.352 & -113.38 \\
\hline 2 & -98.014 & -101.412 & -104.409 & -107.09 & -109.516 & -111.73 & -113.767 \\
\hline 3 & -98.334 & -101.746 & -104.756 & -107.449 & -109.885 & -112.108 & -114.154 \\
\hline 4 & -98.654 & -102.081 & -105.103 & -107.807 & -110.253 & -112.486 & -114.541 \\
\hline 5 & -98.974 & -102.415 & -105.451 & -108.166 & -110.622 & -112.864 & -114.927 \\
\hline 6 & -99.294 & -102.75 & -105.798 & -108.524 & -110.991 & -113.243 & -115.314 \\
\hline 7 & -99.614 & -103.084 & -106.145 & -108.883 & -111.36 & -113.621 & -115.701 \\
\hline 8 & -99.935 & -103.419 & -106.492 & -109.241 & -111.728 & -113.999 & -116.088 \\
\hline 9 & -100.255 & -103.753 & -106.839 & -109.6 & -112.097 & -114.377 & -116.474 \\
\hline 10 & -100.575 & -104.088 & -107.187 & -109.959 & -112.466 & -114.755 & -116.861 \\
\hline 11 & -100.895 & -104.422 & -107.534 & -110.317 & -112.835 & -115.133 & -117.248 \\
\hline 12 & -101.215 & -104.757 & -107.881 & -110.676 & -113.204 & -115.512 & -117.635 \\
\hline 13 & -101.535 & -105.091 & -108.228 & -111.034 & -113.572 & -115.89 & -118.021 \\
\hline 14 & -101.855 & -105.426 & -108.575 & -111.393 & -113.941 & -116.268 & -118.408 \\
\hline 15 & -102.176 & -105.761 & -108.923 & -111.751 & -114.31 & -116.646 & -118.795 \\
\hline 16 & -102.496 & -106.095 & -109.27 & -112.11 & -114.679 & -117.024 & -119.182 \\
\hline 17 & -102.816 & -106.43 & -109.617 & -112.468 & -115.048 & -117.402 & -119.568 \\
\hline 18 & -103.136 & -106.764 & -109.964 & -112.827 & -115.416 & -117.78 & -119.955 \\
\hline 19 & -103.456 & -107.099 & -110.311 & -113.185 & -115.785 & -118.159 & -120.342 \\
\hline 20 & -103.776 & -107.433 & -110.659 & -113.544 & -116.154 & -118.537 & -120.729 \\
\hline
\end{tabular}

Figure 5.8. Matrix applicat in the grid nodes (continuation)

Source: developed by the authors 


\begin{tabular}{|c|c|c|c|c|c|c|c|}
\hline & 14 & 15 & 16 & 17 & 18 & 19 & 20 \\
\hline 0 & -114.863 & -116.604 & -118.233 & -119.763 & -121.205 & -122.569 & -123.863 \\
\hline 1 & -115.258 & -117.006 & -118.642 & -120.178 & -121.627 & -122.997 & -124.297 \\
\hline 2 & -115.653 & -117.409 & -119.051 & -120.594 & -122.048 & -123.424 & -124.73 \\
\hline 3 & -116.048 & -117.811 & -119.46 & -121.009 & -122.47 & -123.852 & -125.163 \\
\hline 4 & -116.442 & -118.213 & -119.869 & -121.425 & -122.892 & -124.28 & -125.596 \\
\hline 5 & -116.837 & -118.615 & -120.278 & -121.841 & -123.314 & -124.707 & -126.029 \\
\hline 6 & -117.232 & -119.017 & -120.687 & -122.256 & -123.736 & -125.135 & -126.462 \\
\hline 7 & -117.627 & -119.419 & -121.097 & -122.672 & -124.157 & -125.562 & -126.895 \\
\hline 8 & -118.021 & -119.822 & -121.506 & -123.088 & -124.579 & -125.99 & -127.328 \\
\hline 9 & -118.416 & -120.224 & -121.915 & -123.503 & -125.001 & -126.417 & -127.761 \\
\hline 10 & -118.811 & -120.626 & -122.324 & -123.919 & -125.423 & -126.845 & -128.195 \\
\hline 11 & -119.206 & -121.028 & -122.733 & -124.334 & -125.844 & -127.273 & -128.628 \\
\hline 12 & -119.6 & -121.43 & -123.142 & -124.75 & -126.266 & -127.7 & -129.061 \\
\hline 13 & -119.995 & -121.832 & -123.551 & -125.166 & -126.688 & -128.128 & -129.494 \\
\hline 14 & -120.39 & -122.235 & -123.96 & -125.581 & -127.11 & -128.555 & -129.927 \\
\hline 15 & -120.784 & -122.637 & -124.369 & -125.997 & -127.532 & -128.983 & -130.36 \\
\hline 16 & -121.179 & -123.039 & -124.778 & -126.413 & -127.953 & -129.411 & -130.793 \\
\hline 17 & -121.574 & -123.441 & -125.188 & -126.828 & -128.375 & -129.838 & -131.226 \\
\hline 18 & -121.969 & -123.843 & -125.597 & -127.244 & -128.797 & -130.266 & -131.659 \\
\hline 19 & -122.363 & -124.245 & -126.006 & -127.659 & -129.219 & -130.693 & -132.093 \\
\hline 20 & -122.758 & -124.648 & -126.415 & -128.075 & -129.64 & -131.121 & -132.526 \\
\hline
\end{tabular}

Figure 5.8. Matrix applicat in the grid nodes (continuation)

Source: developed by the authors

The visualization of the behavior of the potential function of the measuring ionselective electrode from two changes the temperature and concentration of the process water under investigation is made. A matrix applicat is developed in the grid nodes of a two variables function.

\section{References}

Cammann, K. (2012). Working with Ion-Selective Electrodes. Chemical Laboratory Practice. Berlin: Springer Heidelberg.

Otto, M. (2008). Modern methods of analytical chemistry. 3rd edition. Moscow: Technosphere. Tychkov V. V. (2017). Methods for Improving Primary Transducers Quality in the Systems of Automatic Process Water Control. The thesis for the degree of candidate of technical sciences, specialty 05.13.05 - computer systems and components. Cherkasy State Technological University. Avaliable at: https://chdtu.edu.ua/svr/povidomlennya-pro-zakhistdisertatsij/item/8488-povidomlennia-pro-zakhyst-dysertatsii-tychkova-volodymyravolodymyrovycha-za-spetsialnistiu-05-13-05-komp-iuterni-systemy-ta-komponenty.

Tychkov, V. V. (2015). The method of injection analysis.Patent Ukraine No 98197.IPC G01N 35/08, application u 2014 10223, 18.09.2014, Publ. 27.04.2015, Bul. No 8. Avaliable at: http://uapatents.com/5-98197-sposib-inzhekcijjnogo-analizu.html

Tychkov, V. V. (2015). Ultrasonic sample preparation method.Patent Ukraine No 97005.IPC G01N 35/08, G01N 29/22, application u 2014 10407, 22.09.2014, Publ. 25.02.2015, Bul. No 4. Avaliable at: http://uapatents.com/4-97005-sposib-ultrazvukovo-probopidgotovki.html

Halchenko, V. Ya., Trembovetskaya, R. V. (2018). Ddevelopment of RBF-metamodels in surrogate optimization tasks. Theoretical and practical problems of using mathematical 
methods and Computer-Oriented Technologies in Education and Science: Coll. of materials of the II All-Ukrainian Conference (March 28, 2018). Kyiv: Kiev University named by Boris Grinchenko. Avaliable at: http://fitu.kubg.edu.ua/images/stories/Departments/kitmd/20172018/Zbirnyk\%20II\%20Vseukrainskoi\%20konferentsii.pdf

Halchenko, V. Ya., Tychkov, V. V., Trembovetskaya, R. V. (2018). Approximation of the surface of response by means of artificial intelligence. Modern trends in the development of science: materials of the II International scientific and practical conference (23-24 February 2018). Uzhgorod - Kherson : Publishing House "Helvetika". Avaliable at:http://molodyvcheny.in.ua/ru/conf/tech/archive/600/

Trembovetskaya, R. V., Halchenko, V. Ya., Tychkov, V. V. (2018). Determination of the influence of the computational experiment's plan on the efficiency of constructing RBFmetamodels. Theoretical and practical problems of using mathematical methods and ComputerOriented Technologies in Education and Science: Coll. of materials of the II All-Ukrainian Conference (March 28, 2018). Kyiv: Kiev University named by Boris Grinchenko. Avaliable at: http://fitu.kubg.edu.ua/images/stories/Departments/kitmd/2017-

2018/Zbirnyk\%20II\%20Vseukrainskoi\%20konferentsii.pdf

Trembovetskaya, R. V., Halchenko, V. Ya., Tychkov, V.V. (2018). Application of MLPmetamodels in surrogate optimization problems. Young Scientist. №2 (54), 32-39. Avaliable at: http://molodyvcheny.in.ua/files/journal/2018/2/8.pdf

Trembovetskaya, R. V., Halchenko, V. Ya., Tychkov, V. V. (2018). Solving difficult tasks of optimization using metamodels. Information Technologies in Education, Science and Technology" (ITEST-2018): Conference proceedings of IV International Scientific-Practical Conference (Cherkasy, May 17-18, 2018). Cherkasy: ChSTU. Avaliable at: https://chdtu.edu.ua/itont-2018/materiali-konferentsiji

Trembovetskaya, R. V., Halchenko, V. Ya., Tychkov, V. V. (2018). The Approximation Surface Review of the Multidimensional Target Function for Surrogate Optimization Problem. Advanced Information Systems and Technologies: proceedings of the VI international scientific conference (Sumy, May 16-18 2018). Sumy: Sumy State University. Avaliable at: https://drive.google.com/file/d/1NmQOORVnY0ZoeCuzKxDPtNXW5Io93Q9p/view

Tychkov, $V . V$., Trembovetska, R. V. (2017). Estimation of uncertainty of preparation of buffer solutions. Metrological aspects of decision-making in conditions of work on technogenically dangerous objects: materials of the All-Ukrainian scientific and practical conference of applicants of higher education and young scientists. Kharkiv: KhNADU. Avaliable at: http://www.khadi.kharkov.ua/fileadmin/F_Mechanical/metrologiya/sbornik_konf_2017.pdf Tychkov, V. V., Trembovetskaya, R. V. (2015). Strategy of sustainable development of methods of injection analysis. Instrument-making: the state and prospects. Materials of the XIV International Scientific and Technical Conference, April 22-23, 2015. Kiev: PBF NTTU "KPI". Avaliable at: http://pbf.kpi.ua/old/arch/scientific/PB/2015/conf_PB_s5_2015.pdf

Tychkov, V.V., Trembovetskaya, R. V. (2016). Measurement uncertainty evalution result ionometric information-measuring system. Technogenic and ecological safety of Ukraine: the state and prospects of development (TEB-2016): Abstracts of the VI All-Ukrainian scientific and practical Internet conference of students, postgraduates and young scientists. Irpin: UDFSU.

Tychkov, V.V., Trembovetskaya, R. V., Kisil, T. Yu., Bondarenko,Yu. Yu (2017). Usingionselective electrodes in environmental monitoring. 10th International Conference "Environmental Engineering": 10th ICEE. Selected papers. April 27-28, 2017.Vilnius, Lithuania. Avaliable at: DOI: https://doi.org/10.3846/enviro.2017.052; http://enviro.vgtu.lt/index.php/enviro2017/2017/paper/viewFile/5/254 
Tychkov, V. V., Trembovetskaya, R. V., Halchenko, V. Ya. (2018). Criteria for the Selecting Parameters Anode Polarization Process of Substances on the Ion-Selective Electrodes Surface. Environmental sciences. № 20.

Tychkov, V. V., Trembovetskaya, R. V., Halchenko, V. Ya., Kunitskaya,L. G. (2015). The use of a single-parametric regeptional analysis for chrome (VI)-selective electrode manufacture parameters of modeling and optimization. Comprehensive assurance of the quality of technological processes and systems (CAQTPS-2018): materials of reports theses of the VIII International Scientific and Practical Conference (Chernihiv, May 10-12, 2018). Chernigov: CSTU. V. 2, 139-141. Avaliable at: http://www.stu.cn.ua/media/files/conference/Tezy\%20\%202018\%20Part\%202.pdf

Tychkov, V. V., Trembovetskaya, R. V., Halchenko, V. Ya., Kunitskaya,L. G. (2018). Regression Analysis Application for the Uncertainty Estimation of the Ionometric Converters Graduation. Information Technologies in Education, Science and Technology" (ITEST-2018): Conference proceedings of IV International Scientific-Practical Conference: Cherkasy (May 17-18, 2018). Cherkasy: ChSTU. Avaliable at: https://chdtu.edu.ua/itont-2018/materiali-konferentsiji.

\title{
5.2. INTERNATIONAL COMPETITIVENESS OF SECONDARY MINERAL RESOURCES DUE TO GLOBALIZATION OF ECOLOGICAL AND ECONOMIC PROBLEMS
}

\author{
Iryna Maksymova
}

PhD (Economics), Associate Professor of the International Economics Department, Kryvyi Rih Economic Institute of Kyiv National Economic University named after Vadym Hetman, Kryvyi Rih, Ukraine

Iryna Yegorova

PhD (Economics), Associate Professor,

Associate Professorof the International Economics Department,

Kryvyi Rih Economic Institute of Kyiv National Economic University named after Vadym

Hetman, Kryvyi Rih, Ukraine

Hanna Puriy

PhD (Economics), Associate Professor of the International Economics Department, Kryvyi Rih Economic Institute of Kyiv National Economic University named after Vadym

Hetman, Kryvyi Rih, Ukraine

Kala,

Prof. Universite Internationale Jean Paul II de Bafang, Cameroon

Today, such notions as "green economy", "ecological globalization" and "corporate social responsibility" are becoming more comprehensible and even vital for a human being. Thus, modern society forces the business to rethink its attitude towards natural resource exploration and management. However, despite the high level of innovative technologies, industry is not able to abandon the applying of Earth's natural resources without declining economic efficiency of business. Nevertheless, many productions are capable of processing natural resources in an environmentally friendly manner.

To be more specific, ecological globalization contributes to significant growth of the competitiveness of secondary mineral resources due to the global depletion of the basic mineral base. This statement raises the following scientific issues: What conditions make secondary 
mineral resources competitive? What are the social and ecological effects from the exploration of secondary mineral resources? What benefits will enterprises acquire from the development of secondary mineral resources? How will the involvement of secondary mineral resources affect the distribution of world power in the international market?

Solving these issues contributes to the effective strategy of regional development all over the world. Moreover, mining and metallurgical industries have already faced with the problem of optimal resource management in the context of economic effectiveness and environmental acceptance. These enterprises are striking example of a business which competitiveness directly depends on the quality of raw material base - iron ore reserves.

Besides, scientists and business analytics distinguish three international scenarios of world development due to economic and ecological globalization (Fig. 5.9).

\begin{tabular}{|l|}
\hline \multicolumn{1}{|c|}{$\begin{array}{l}\text { Green Trade Alliance (GTA) } \\
\text { - radical environmental standards } \\
\text { and sustainability in GTA } \\
\text { countries, thus, prevention the } \\
\text { climate change; } \\
\text { - accelerating innovation and } \\
\text { changing consumer behavior; } \\
\text { - restricted cross-border flows } \\
\text { between GTA and non-GTA } \\
\text { countries. }\end{array}$} \\
\begin{tabular}{l|l}
\multicolumn{1}{|c|}{ Resource Security } \\
- national self-interests dominate \\
globalism; \\
- limited cross-border flows of \\
products, labour, capital; \\
- society uses most available \\
domestic resources, irrespective of \\
impact on environment.
\end{tabular} \\
$\begin{array}{l}\text { Rebased Globalism } \\
\text { countries with strong demand } \\
\text { and resource-rich countries. } \\
\text { - cross-border flows are open } \\
\text { (benefits of globalization and } \\
\text { interconnectedness). } \\
\text { - slight environmental policy, } \\
\text { thus, adaptation to climate } \\
\text { change. }\end{array}$ \\
\hline
\end{tabular}

Figure 5.9. Global scenarios to 2030

Source: developed by the authors based on (Hinchberger, W., 2016)

All these scenarios mainly affect governmental policy of resource management and, thus, influence the market of mineral resources. The most ecologically approved scenario is Green Trade Alliance, aimed to guarantee strong resource policy and prevent climate change. The most resource devastative is scenario of Resource security. Rebased globalism is envisaged as global regime erasing borders between countries. Due to this scenario, economic power in the iron ore market will be held in the USA, China, India, Brazil and EU that provide strong demand and control main part of world iron ore resources.

Today, we observe some trends of these scenarios in the real economy and directly in the mineral resources market. Globally, iron ore production has been increasing considerably since 2000 because of substantial growth of metallurgy and steel industry (Fig. 5.10). 


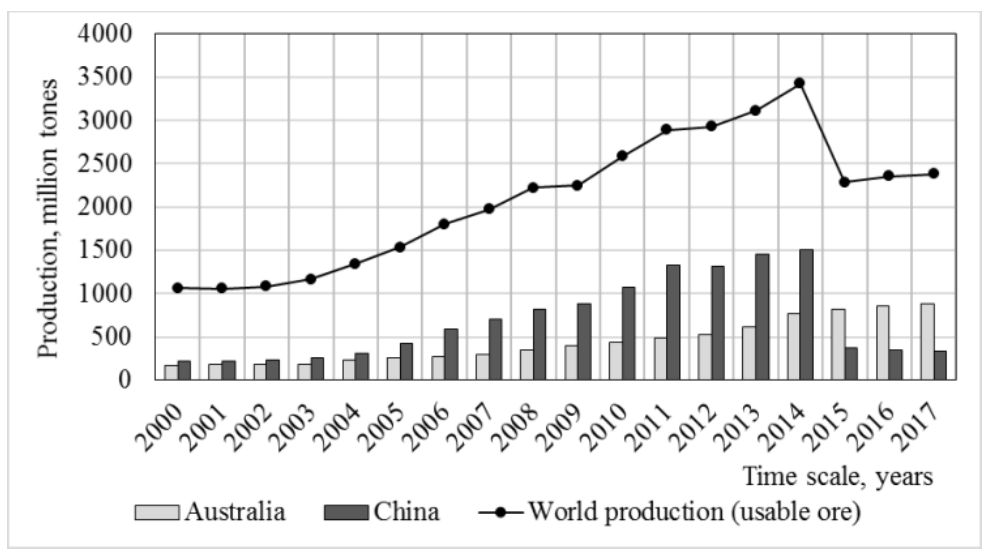

Figure 5.10. World production of iron ore

Source: developed by the authors based on Mineral commodity summaries, 2018

The diagram depicts main peak of iron ore production in 2014. Despite its fall in 2015, industry is still growing. Moreover, China's export of iron ore dropped sharply in 2015 although China's import gradually increased. This situation creates an ideal market conditions for such large players as Australia and Brazil that steadily increase their production (Fig. 5.11).

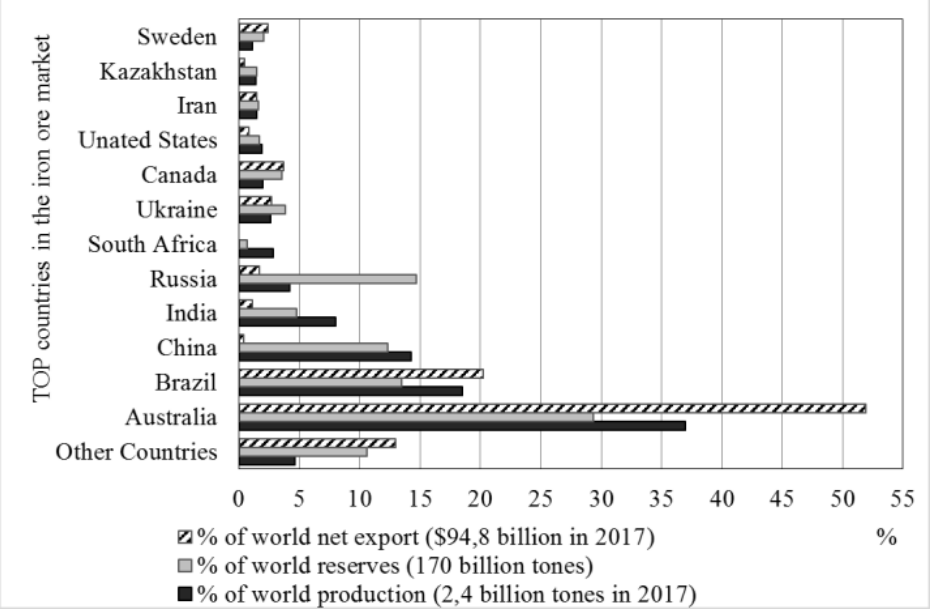

Figure 5.11. Iron ore market in 2017

Source: developed by the authors based on Iron Ore Market Report, 2017.

The bar chart represents TOP-ranked countries in the market of iron ore. Remarkably, this market is conducted by several competitors and it is rather concentrated than fragmented. To be more specific, 9 countries cover $95 \%$ of global export of iron ore and only 3 countries provide over $65 \%$ of iron ore production. Besides, there are 10 world's largest iron ore conglomerates in the market: BHP Billiton (Australia), Rio Tinto (United Kingdom), Vale (Brazil), Glencore International (Switzerland), Anglo American plc (United Kingdom), ArcelorMittal (Luxembourg), Fortescue Metals Group (Australia), Severstal (Russia), Vedanta Resources (United Kingdom) and Evraz Group (United Kingdom). 
In practice, international sales of iron ore declined from 143 billionUSD to 95 billion USD since 2014 and, as a result, global export of iron ore gained 15\% for the same period. Overall prices foriron orepeaked at around70 USD per ton in 2017, and hit a low of about 50USD. Moreover, Chinese demand was a driver in pushing prices up and down during the period.

Complex data analysis (WerkheiserW.H.,2018) allowed us to draw the following conclusions. The intensity of production of iron ore rises every year to meet the growing needs of the industry. However, in-situ quantities of iron ore are not immense. In theory, current iron ore reserves are enough for 70-year period of production (development of explored ore deposits, about 180 billion tones) and for 400-year period (if we assume the technical capacity, environmental feasibility and territorial availability of extraction of all known reserves, about 800 billion tons). At the same time, as Rock, O. and Ema, A. (2015) noted, mining activity generates a plethora of mining waste. The most ecological impacts are the following: dust, noise, intrusion on the landscape, the emission of pollutants into the air and surrounding watercourses, lakes and groundwater. The mining industry is also a major consumer of energy. However, the most significant environmental aspect of mines is linked to the management of mining waste, which can create long-term ecological problems. In order to extract 1 ton of ore, it is necessary to excavate about 2-10 tons of overburden.

Thus, many scientists (Lewis L. \& Tietenberg T. (2016); Bergstrom J. \& Randall A. (2016); Söderholm K., Helenius H., Pettersson M. (2015); Yellishetty M. \& Mudd G. (2014); Maksimova I. \& Maksimov I. (2017); Cleaver F. (2012) et al.) claim, that globalization of economic and environmental problems should encourage the launching of new resource management projects, for instance, exploration of secondary mineral resources. Today, mining waste could be considered as a secondary mineral resource because of affordable level of iron content in it.

Broadly speaking, secondary mineral resources include only those wastes that can be effectively used in the national economy taking into account current stage of scientific and technical development (Lewis L. \& Tietenberg T., 2016). Therefore, the following types of wastes relate to secondary mineral resources:

- remains of raw materials formed during manufacturing process and not completely lost their value;

- products of physical and chemical processing of raw materials, which can be used after finalization as finished products or as raw materials for further processing;

- products obtained during the extraction and enrichment of minerals.

Söderholm K., Helenius H., Pettersson M. (2015) noted that the competitiveness of secondary mineral resources implies the possibility of its processing with acquiring a sufficient economic effect.

In mining industry there are several types of secondary mineral resources:

- mining waste (overburden and enclosing rocks, as well as sub-standard and offbalanced iron ores); enrichment);

-wastes of enrichment (waste from crushing and sorting factories, tailings of

- agglomeration waste (screenings, dust and sludge);

- wastes from metallurgical production (metallurgical slag, dust and sludge).

Most of them could be recycled with using special technologies. Yellishetty M., Mudd G. M. (2014) wrote more about USA, Canada, Japan, Great Britain, Germany, Australia and South Africa accumulated great experience in this case. 
The flaw chart (Fig. 5.12) illustrates the fact that secondary mineral resources are mostly concentrated in the gangues, tailings and overburden. Gangue is a waste arising from mining. Both surface and underground mining often require large quantities of rock to be broken away to reach the ore. Gangue is usually placed in heaps near the mine. Tailings are a fine-grained residue, mainly consisting of gangue minerals that remain after the separation of valuable minerals and metals from ore.

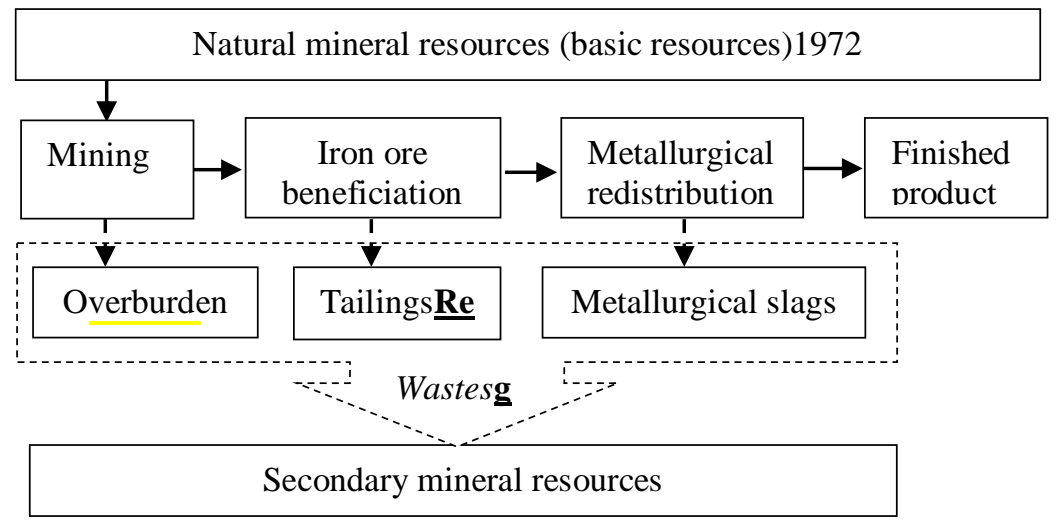

Figure 5.12. Flow chart of formation of secondary mineral resources Source: developed by the authors based on Yellishetty M., Mudd G. M. (2014)

There is no data on how much waste is generated by mining industry globally, but about 34 billion tons of overburden has been accumulated in mining dumps, including $30 \%$ for ferrous metallurgy, 23\% for coal industry, 21\% for non-ferrous metallurgy, 15\% for fertilizers and 9\% for construction. The area of dumps in the coal and metallurgical industries is about 200 thousand hectares. The cost for keeping such wastes is about 2.5 billion USD annually.We could distinguish several conditions for the competitiveness of secondary mineral resources in the global economy, Fig. 5.13.

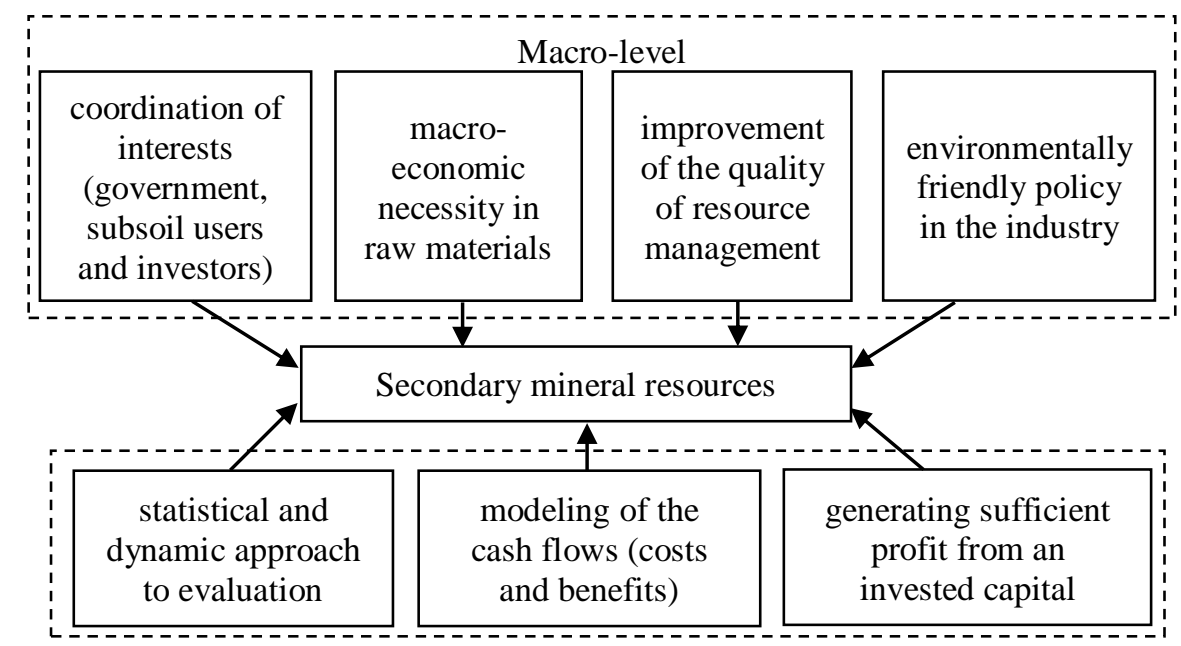

Figure 5.13. Competitiveness model of secondary mineral resources

Source: developed by the authors 
To begin with, the first group of conditions links to the macro-level of resource management. These conditions contribute to the competitiveness of secondary mineral resources.

For example, macroeconomic necessity of raw materials is envisaged as a "demand" in the context of national economy and society as a whole. The shortage of iron ore and other basic minerals increases the importance of secondary mineral resources in conditions of adverse ecological situation, taking into account economic, environmental and social consequences of its exploration.

Under market conditions, the principle of macroeconomic necessity of raw materials is provided through freely established prices for raw materials, and also through state regulation of industries and regions development. Thus, prices increase with demand growth and decrease with its fall. Moreover, preferential taxation and special loans for the development of secondary mineral resources are widely introduced in accordance with governmental policy.

Besides, Söderholm K., Helenius H., Pettersson M. (2015) noted that elaboration of secondary mineral resources becomes possible only under mutual interests of state authorities, investors and subsoil users who subjects to taxes, fees and other payments prescribed for commercial organizations.

On the other hand, extraction of secondary mineral resources implies generating sufficient profit from an invested capital. Thus, mining projects need special methodology for the evaluation of secondary mineral resources. This methodology is based on statistical assessment, dynamic modelling, cash flaw modelling, and evaluation of the economic benefits and ecological effects from secondary mineral resources.

High competitiveness of secondary mineral resources is directly confirmed by the effects resulted from their extraction. These effects are related to economic, social and ecological sphere and include the following:

- preservation of basic mineral resources;

- complex and optimal extraction of minerals;

- savings on transportation costs on mineral resources and raw materials;

- less investment in capital construction;

- cost savings on mining dumps due to waste recycling;

- reducing the harmful impact on the environment.

In practice, there are many project iterations related to extraction of secondary mineral resources, but we usually tend to choose project with the most profound effect for the enterprise, environment, society and regional development. This task becomes quite difficult because business owners' interests are usually dominating social and environmental targets. Thus, main criteria of effectiveness should integrate separated effects obtained from complex mineral resource extraction, for instance are:

$$
E=E_{b m r}+E_{s m r}+E_{e c} \rightarrow \max (5.3)
$$

where $E$ - complex economic effect, USD; $E_{b m r}$ - economic effect of basic mineral resources, USD; $E_{s m r}$ - economic effect of secondary mineral resources, USD; $E_{e c}$ - ecological effect of reducing environmental damage, USD.

Furthermore, such model (5.3) should imply possible depreciation of money, because large-scale mining projects are usually planned for several years, for example: 
$E_{b m r}=\sum_{t=1}^{T} \frac{\left(P_{i}-C_{i}\right) \cdot A_{i}}{(1+d)^{t}}$

where $P_{i}$ - price of some mineral resource, USD/t; $C_{i}-$ costs of mining and processing, USD/t; $A_{i}$ - production capacity of mine, ton a year; $d$ - discount rate; $T$ - period mine exploration, years.

Model of competitiveness of secondary mineral resources will be represented by the example of iron ore extraction in Ukraine. Moreover, we disclose the problem of off-balanced ore extraction as an example of secondary mineral resources.

As shown earlier, today the key line of many studies concerns the issues of resource management at the industrial raw enterprises and assessment of their efficiency. At the modern stage of industrial and economic development the economic efficiency of underground extraction requires the solution of actual issues related to their resource base expansion, production performance optimization, reducing the pace of deepening mining operations while maintaining the quality and competitiveness of iron ore products. This is particularly important for mining companies of Ukraine whose activity provides a significant contribution to the economic development of the entire industry. At present, the economic efficiency of underground mining is significantly reduced due to achievement of significant production depth (more than $1400 \mathrm{~m}$ ), dynamic growth in energy and materials prices, an increase of dumping costs and complexity of the conditions of ore extraction.

Under these conditions, involvement in the development secondary mineral resources, which have been classified as off-balance and not mined, can become the production strategy of a mining enterprise. Such a significant amount of the off-balance reserves is present at any mine. However, the complexity of the study of economic feasibility and efficiency of the offbalance reserves extraction is explained by the fact that, in some of their parameters, they may differ significantly from the standards for iron ore. Today, off-balance reserves of enterprises are being lost by enterprises almost in full due to the lack of the overall economic mechanism for the substantiation of their extraction expediency. Based on the above, the formation the mechanism of the economic justification of the off-balance reserves development expediency is an urgent task. Its solution is important for the growth of economic efficiency of mining, expansion of the resource base and the development of the mining enterprises of Ukraine in crisis conditions.

As a result of our study, we have arrived at the conclusion that in modern conditions of industrial and economic development, attracting part of the off-balance reserves of iron ores to the operation cycle is a competitive project of underground mining. It contributes to the solution of such important management issues as:

- the expansion of the raw material base of the mining companies;

- the growth of its revenue by attracting additional sources of raw materials;

- maintaining stable production capacity of mines;

- the extension of period of cost-effective operation of mines;

- reducing the rate of costly deepening of mining operations;

- reducing the cost of mining;

- the growth of ecological and economic efficiency by reducing the intensity of heaps formation; 
- compliance with the state program of mineral resources base development in Ukraine for the period until 2030, which provides for the need of economically and technologically optimal, integrated and comprehensive use of mineral resources.

In most cases, the cost of the off-balance reserves production is lower, because they occur with the advancing of the mining front and on the upper floors which are already passed, which makes it possible to involve them in the production process through the use of already passed mining developments and constructed lifting systems.

Production strategy of mining companies can be effectively accomplished through a combination of the following components: on the one hand - thepresence and availability of the off-balance reserves for mining (their amount is usually up to 20-30\% of the mine reserve), and on the other hand - introductionof the economic mechanism of feasibility study for such reserves mining.

For economic assessment of reserves at a mining company we propose to introduce the concept of "economically promising off-balance reserves" - this is part of the sub-standard ores which, on the basis of their economic value, cost of production and technologically acceptable locations are economically viable for mining in the current economic and geotechnical conditions of the enterprise. Involvement of these stocks is profitable for a company and contributes to obtaining an additional economic benefit to it.

Economic efficiency of the off-balance reserves development is explained, on the one hand - with the cost of production and processing, and on the other hand - with the income that mining company can receive from the sale of marketable ore seized from each ton of the offbalance reserves. These rates differ for different mining units depending on the characteristics of their development, which ultimately determines the economic expediency of the off-balance reserves attraction to the production process.

The first step is creation of model of efficiency estimation of anti-crisis decisions at the management of iron ore companies. Given the above, the system of economic efficiency indicators of the off-balance reserves development it formed.

We have developed an analytical criterion - the index of economic efficiency, which allows comparing the development of the main indicators of the balance and off-balance reserves, namely, the volume of commodity ore produced by the company, conditioning the amount of income and the economic value of reserves and the cost of their mining and processing.

$$
I_{E}=\frac{Q_{m 2 .}}{C_{2}} \times \frac{C_{1}}{Q_{m 1}},
$$

where $I_{E}$ is the index of economic efficiency of the off-balance reserves development (as secondary mineral resources), the proportion of units; $Q_{m 1}, Q_{m 2}$ is the volume of marketable ore, produced from balance reserves and off-balance reserves correspondingly, $\mathrm{t}, C_{1}, C_{2}$ is the cost of mining and processing balance reserves and off-balance reserves correspondingly, USD (Maksimova I.I.\& Maksimov I.I., 2017).

It is shown that the most indicative for the evaluation of the competitiveness and economic feasibility of the off-balance reserves are the following values of the index (5.5).

In terms of $I E \geq 1$ or $I E \rightarrow 1$ the off-balance reserves can be regarded as the most competitive (a cost perspective). These index values indicate that the amount of commercial ore, now received as a result of the off-balance ores mining, and the cost of their production and processing is sufficient to provide the same effectiveness as in the development of balance 
reserves of the mine. Furthermore, when $I E \geq 1$, the off-balance reserves can be involved in the development as an alternative to balance mine reserves that will not only expand the raw material base, but will also contribute to the prolongation of the effective operation of mining horizons.

When $0.9<I E \leq 1$, off-balance reserves mining is more efficient than the mining of balance reserves in the lower producing horizons. When $I E<0.9$, off-balance reserves mining is not economically viable in the current economic and geotechnical conditions of the enterprise.

However, off-balance reserves index in the range $0.7<I E \leq 0.9$ may eventually go into the category of economically promising in case of reducing the quality requirements to raw materials, technology development and cost reduction.

As a result, overall economic effect of the off-balance reserves mining is studied as an integral component, which is formed from such partial effects:

$$
\Delta E=\left\{\begin{array}{lr}
\sum_{t=1}^{T} E_{\Delta V} \cdot d_{t} & \text { (value effect }) \\
\sum_{t=1}^{T} E_{\Delta C} \cdot d_{t}+\sum_{t=1}^{T} E_{\Delta C p} \cdot d_{t} & (\text { cost effect }) \\
\sum_{t=1}^{T} E_{\Delta I} \cdot \alpha_{t} & (\text { investment effect }) \\
\sum_{t=1}^{T} E_{\text {ecol }} \cdot \alpha_{t} & (\text { ecological effect })
\end{array}\right.
$$

where $\Delta E$ is economic effect of mining off-balance reserves, USD / $\mathrm{t} ; T$ is the period during which the mining company involves in the operation the off-balance reserves, years; $d_{t}$ is the discount rate (coefficient for raising multi-temporal costs and benefits to the calculated year $t$ ), the proportion of units;. $E_{\Delta V}$ is the effect (loss) from changes in the economic value of the remote reserves in attracting off-balance ore to the production, USD / $\mathrm{t} ; E_{\Delta C}$ is the effect (loss) obtained by reducing or increasing the cost during the reserves mining, USD / t. $E_{\triangle C p}$ is the effect (loss) obtained by reducing or increasing the cost of ore processing at the processing plant, USD / t; $E_{\Delta I}$ is the effect (loss) obtained by changing the efficiency of investment, USD / $\mathrm{t}$; $E_{\text {ecoli }}$ is the effect obtained by saving the cost of the environmental tax payment, USD / $\mathrm{t}$.

Studies of peculiar features of economic outcomes and costs formation when developing off-balance reserves led to the conclusion that the overall effect of such engagement will have ecological component $\left(E_{\text {ecol }}\right)$. The $E_{\text {ecol }}$ effect will be obtained if instead of storing off-balance reserves on the surface, the company will involve part of them to the production process and thus eliminate the need for environmental tax payment for dumps formation and maintenance. Otherwise economic efficiency of this ore development in the future is reduced due to the fact that in the dumps, under the influence of natural factors, iron ore irreparably loses much of its economic value.

Determination of the integral economic effect by the formula (4) allows you to explore its structure and determine whether the correlation between the obtained economic results and costs is sufficient to ensure the economic feasibility of the off-balance reserves mining.

Implementation of economic mechanism of secondary mineral resources development is shown by the example of JSC "EVRAZ Suha Balka" (mine "Yuvileyna" and mine named after Frunze). The study showed that part of the off-balance reserves is economically viable for 
mining at the enterprise. The index of economic efficiency of such off-balance reserves is usually in the range $(I E=0.9 \ldots 1)$, and in some cases even $I E>1$.

According to the calculations we have studied the dynamics of fluctuations in profit (P, USD / ton), depending on the performance of iron content in the ore (Fe,\%) and production costs (C, USD / ton), which made it possible to define the following graduation in its changes:

Group I, II are the off-balance reserves which are economically feasible to involve in the mining process, as the profit from their development exceeds the average profit indicator for the balance reserves of the mine. These reserves can be involved not only as an additional production volume, but also as an alternative to part of balance reserves, which will ultimately extend the term of the mine effective functioning.

Group III - off-balance reserves, profits from which are lower, but for the company their development is economically more efficient than mining of balance reserves in the lower mining horizons. Consequently, the reserves of this zone are also economically promising, and they should be involved in the development with a view to the overall increase in production volumes.

Group IV, V - off-balance reserves, profits from which are significantly lower than in case of balance reserves mining. These reserves are not economically feasible to develop at present.

However, with technological development and changing market conditions, the reserves of group IV can go to the III, and their economic value will be revised.

The study led to the conclusion that secondary mineral resources create new competitive reserves for economic development under globalization. This statement (Maksimova I.I.\& Maksimov I.I., 2017) confirms the idea, that modern enterprises faced with the necessity to rethink traditional approaches to natural resource management. More specifically, modern anticrisis and cost-effective production strategy for the mining company is involving off-balance reserves of higher and current mining horizons in the mining process with the purpose of obtaining additional economic benefits and reduction in the rate of mining operations deepening. This production strategy can also be proposed in order to increase overall performance, achieve the original design capacity of the mines, reduce the production cost and achieve the growth of economic efficiency of underground mining. At the level of the mining enterprise, the strategy can be considered in two dimensions:

1. Obtaining significant additional economic benefits by increasing production volumes subject to the availability of free reserves of production capacity of mines.

2. Off-balance reserves involvement at a constant performance of the mine in order to reduce the rate of mining operations deepening. In this case, the company will receive economic benefit comparing to mining in the underlying horizons. The time for the development of the mining horizon increases. We have found out that the expansion of the resource base by $20 \%$ due to the off-balance reserves extraction will provide ore mining company with an extra year of cost-effective operation of the mine for every 5 years of development of the reserves.

By the example of Kryvyi Rih Basin, we have shown that withdrawal of the off-balance reserves from some mining blocks, totalling 400 thousand tonnes (up to $20 \%$ of annual mine production), will enable the company to obtain additional economic benefit of 760 thousand USD (15\% of the mine profits) with a corresponding increase in productivity and production volumes. At the sustainable annual productivity, economic benefits, compared to mining reserves in the lower horizons, will amount to 329 thousand USD, and the intensity of the lowering of mining operations will decrease by 1.2 times. Thus, the production cost of mining off-balance reserves is by $17.5 \%$ lower than in the process of balance ore extraction at the underlying mining horizons. 
Under these conditions, the involvement of secondary mineral resources into production cycle is a competitive strategy that contributes to the targets of a green economy and optimal resource management. Besides, such projects are economically viable for the mining enterprise and ecologically sustainable for the regional development.

\section{References}

Bergstrom, J .C.,Randall A. Resource Economics:An Economic Approach to Natural Resource and Environmental Policy: fourth edition. USA: Edward Elgar Publishing. Cleaver, F. (2012).Development Through Bricolage. Rethinking Institutions for Natural Resource Management. London: Routledge.

Ericsson, M.,Löf, A. (2017). Iron Ore Market Report 2017.Engineering and Mining Journal. Vol. 11, 32-37.

Hinchberger, W. (2016).Mining \& Metal Scenarios to 2030.Geneva: World economic forum in collabor. with McKinsey Company..

Lewis L., Tietenberg T. (2016). Environmental and natural resource economics: 9th edition. Great Britain: Pearson Addison Wesley Publishers.

Maksimova, I.I., Maksimov I.I. (2017). Efficiency estimation of anti-crisis decisions in the management of up-to date raw enterprises. Periodyk naukowy akademii polonijnej. Vol.4, 67-74.

RockO.,Ema, A. (2015). Environmental Problems of Surface and Underground Mining: a review. The International Journal of Engineering And Science. Vol. 4, 12-20/

Söderholm, K., Helenius, H., Pettersson, M.(2015). Environmental regulation and competitiveness in the mining industry: Permitting processes with special focus on Finland, Sweden and Russia. Resources Policy. Vol. 43, 130-142.

Tuck, Ch. A., Xun, S., Singerling, S. A (2017). Global iron ore production data.Clarification of reporting from the USGS.Mining engineering. February 2017, 20-24.

Werkheiser,W. H. (2018).Mineral commodity summaries 2018. Virginia: U.S. Geological Survey.

Yellishetty M., Mudd G. M.(2014). Substance flow analysis of steel and long term sustainability of iron ore resources in Australia, Brazil, China and India.Journal of Cleaner Production. Vol. 84, 400-410.

\subsection{ENVIRONMENTAL ASPECTS OF ENERGY COMPONENT FOR THE SUSTAINABLE DEVELOPMENT OF THE REGIONS OF UKRAINE}

\section{Olena Khomenko}

PhD (Chemical Sciences), Professor, Head of the Ecology Department, Cherkasy State Technological University, Cherkasy, Ukraine

\section{Nelli Zagoruyko}

PhD (Biological Sciences), Associate Professor,

Associate Professor of the Ecology Department, Cherkasy State Technological University, Cherkasy, Ukraine

The current state of the society development displays the signs of a global ecological crisis. The increasing scale of human impact on the natural environment has reached a disastrous level causing irreversible changes in natural processes and degradation of environmental components. 
The human civilization is under the threat of existance. One of the main reasons for the worsening of relations "man-environment" is the use of traditional energy sources that is fossil fuel or carbon-containing fuel. The use of traditional energy sources in industry and transport produces simultaneously two problems: the increase in carbon dioxide emissions and provoking of the greenhouse effect in the planet's atmosphere as well as the depletion of energy resources.

In this regard, in the developed countries a revision of energy policies towards greater use of renewable energy sources formed. In September 2015, at the 70th meeting of the United Nations a new concept of "Transforming of our world: the 2030 agenda for the sustainable development" was adopetd, which in the energy sector providesd, in particular, the growth of energy efficiency; doubling the share of renewable energy sources (RES) in the global energy balance. The renewable energy in 2015 developed under the influence of the sharp decline in world prices for fossil fuels; the reduction in prices of renewable energy under long-term contracts; increased attention to energy efficiency among countries, as well as the adoption of the Paris climate agreement, according to which 191 countries of the world agreed to keep the rise in the average global temperature between $20 \mathrm{C}$ by 2100 . Today most of the world via climate commitments (Intended Nationally Determined Contributions) develop renewable energy and implement energy efficiency measures. Overall global capacity growth in the renewable energy in 2015 increased compared with 2014 almost by $9 \%$ (148 GW), reaching $1849 \mathrm{GW}$. It is worth noting that for the first time in the history of energy the growth of new capacities of renewable energy exceeded that of the traditional of the ninth generation that is a testament to the competitiveness of the renewable energy among primary energy sources. For the second consecutive year the largest increase in capacity is represented by wind and solar energy, around $77 \%$ of all new capacity from the renewable energy sources. Nowadays there are about 148 already completed and planned projects to replace the use of fossil fuels and a largescale transition to the renewable energy and low carbon energy sources. According to the report, REN21, Renewables Global Status Report 2016 the share of RES in the total electricity production in the world in 2015 was $23.7 \%$, while hydro power accounted for $16.6 \%$, wind energy $-3.7 \%$ and solar energy $-1.2 \%$, and biomass $-2 \%$ geothermal energy, energy of the oceans and concentrated solar energy -0.4 percent. The largest producers of "green" electricity are seven countries the total capacity of which amounts to $71.5 \%$ of the world (470 GW, excluding hydro energy): China, USA, Germany, Italy, Spain, Japan, and India. The International Renewable Energy Agency (IRENA) developed a Road map to achieve a doubling of the share of renewable energy in the global energy consumption for the 2010-2030 periods: $18 \%$ of renewable energy in total final energy consumption (2010) to $36 \%$ (2030).

Starting from 2015, a trend of increasing role of the alternative energy sources was clearly formed. Despite the moderate increase in global energy demand in 2015 the production of alternative energy sources continued to grow rapidly, rising by $15.2 \%$ compared to 2005 , which confirms their competitiveness. The world consumption of coal decreased by $1.8 \%$ compared with the average growth in previous 10 years at $2.1 \%$. Unlike coal market, the demand for oil and natural gas increased respectively by $1.9 \%$ and $1.7 \%$. The EU announced ambitious plans for the phasing-out of traditional energy sources by 2020 (table 5.2).

A Significant potential to reduce emissions of greenhouse gases (effective from the viewpoint of costs) are in the States with the transition economies in the industrial, residential sector, in heating systems and the systems of energy transportation. According to the IEA, the state should organize and control the fuel efficiency standards for industry and construction, to encourage the introduction of renewable energy sources and to control the prices of carbon emissions. 
Table 5.2. The obligations of the EU member countries about the renewable energy according to Directive 2009/28/EC

\begin{tabular}{|c|c|c|}
\hline \multirow[t]{2}{*}{ Country } & \multicolumn{2}{|c|}{$\begin{array}{l}\text { The share of energy from renewable sources in total final energy } \\
\text { consumption, }(\%)\end{array}$} \\
\hline & Actual data for 2005 & The target for 2020 \\
\hline Belgium & 2,2 & 13 \\
\hline Bulgaria & 9.4 & 16 \\
\hline Czech Republic & 6.1 & 13 \\
\hline Denmark & 17.0 & 30 \\
\hline Germany & 5.8 & 18 \\
\hline Estonia & 18,0 & 25 \\
\hline Ireland & 3,1 & 16 \\
\hline Greece & 6.9 & 18 \\
\hline Spain & 8,7 & 20 \\
\hline France & 10.3 & 23 \\
\hline Italy & 5.2 & 17 \\
\hline Cyprus & 2.9 & 13 \\
\hline Latvia & 32.6 & 40 \\
\hline Lithuania & 15.0 & 23 \\
\hline Luxembourg & 0.9 & 11 \\
\hline Hungary & 4.3 & 13 \\
\hline Malta & 0.0 & 10 \\
\hline Netherlands & 2.4 & 14 \\
\hline Austria & 23.3 & 34 \\
\hline Poland & 7.2 & 15 \\
\hline Portugal & 20.5 & 31 \\
\hline Romania & 17.8 & 24 \\
\hline Slovenia & 16 & 25 \\
\hline Slovakia & 6.7 & 14 \\
\hline Finland & 28,5 & 38 \\
\hline Sweden & 39.8 & 49 \\
\hline UK & 1.3 & 15 \\
\hline
\end{tabular}

Source: Directive 2009/28/EC of the European Parliament and of the Council of 23 April 2009 on the promotion of the use of energy from renewable sources and amending and subsequently repealing Directives 2001/77/ EC and 2003/30/EC Avaliable at: http://eurlex.europa.eu/legal-content/EN/ ALL/

Thermal power plants, installations for steam power in agriculture industry are the source of major atmospheric emissions and solid waste tonnage. The composition of flue gas includes carbon dioxide, dioxide and sulfur trioxide and a number of other components whose emissions into the air cause a great damage to the main components of the biosphere. In addition to gaseous emissions the heat power industry is the "producer" of large volumes of solid wastes with the carbon supply tails, ash and slag deposits. The pollution and waste from energy facilities in the the forms of gas, liquid and solid phase are distributed into two streams: the first is a global change, and the other is regional and local. The heat power industry in the result of fossil fuels combustion remains a major source of global pollutants. Due to their accumulation the concentration of the minor atmospheric gases, including GHGs, changes. According to the recommendations of international energy organizations Ukraine 
and policy of climate change: the economic aspect, the analytical report of the Razumkov Center, according to BP Statistical Review of World Energy", 2016) the most effective method of GHG emissions reduction is the introduction of energy-efficient and energy-saving technologies.

New Ukraine's Energy strategy (NES) by 2035 "Security, efficiency, competitiveness" (NES 2035) approved by the government, defines the goals and objectives of the energy sector development in accordance with the needs of economic and social development for the period up to 2035. The main provisions of the NES-2035 are based on the best practices of European countries and lay the foundations for the energy-efficient society and take into account the provisions of the Paris agreements and Ukraine's commitments to reduce greenhouse gas emissions by 2030. The main goal of the energy development for the period up to 2035 is to ensure energy and environmental security, the transition to the energy efficient and energy saving use and consumption of energy with the introduction of innovative technologies. In accordance with the projected structure of the total primary energy supply, the amounts of fossil resources will decrease in 2035 compared to 2015, and renewable resources will increase over this period by $21 \%$. In the field of environmental protection in accordance with the project NES-2035 the compliance with the high environmental standards of energy production, transportation, conversion and consumption; financing of investment projects in the framework of the National plan for the reduction of emissions from large combustion plants according to the Ukrainian legislation and of the obligations to the EU and to introduce measures to limit the impact of energy on the environment must be ensured. A nuclear power, hydropower, expansion of the use of all forms of renewable energy that have the lowest greenhouse gas emissions will play an important role in the implementation of the de-carbonization of the energy sector. The project NES-2035 in this area identified the following objectives:

- reduction of GDP energy intensity, total primary energy supply (TES) from 0.24 in 2015 to 0.13 tons /1000 USD GDP (PPP) in 2035;

- increase the share of renewable energy sources (RES) in SPE (including capacity of hydroelectric and thermal energy) $4 \%$ in 2015 to $25 \%$ in 2035 ;

- increase the share of renewable energy in electricity generation (including capacity of hydroelectric and thermal energy) from $5 \%$ in 2015 to $25 \%$ in 2035 ;

- increase the share of renewable energy in local energy balances (in \% of total consumption) from $10 \%$ in 2020 to $20 \%$ in 2035 ;

- limiting $\mathrm{CO}_{2}$ emissions to the levels of 1990.

The study of the electricity consumption structure in Ukraine shows that the main consumer is the population (more than $31.8 \%$ ), utilities and public consumers (18.6\%), whose share in the total structure of consumers is more than $50 \%$ (Fig. 5.14). In this regard, the energy efficiency utilities and public institutions and increasing public interest in energy saving technologies have become a priority for local communities of the regions of Ukraine.

In the framework of the NES-2035 implementation the Government supposes power decentralisation, resources transfer and responsibility for the functioning of housing and communal services and municipal power at the local level; promoting decentralized energy supply systems, use of local fuels and renewable sources of energy. At the regional level in Ukraine with the development strategies of the regions local authorities necessarily involve an energy component which is largely determined by the economic development of the region and the presence or absence of energy in the production and consumption of energy.

Cherkasy region is the Central region of Ukraine, which despite the availability of sufficient energy capacity is considered to be power-hungry. Therefore, the strategy of Cherkasy region 
development until 2020 provides solutions to the region's energy problems by switching to alternative energy sources through the introduction of energy efficiency measures (tab. 5.3).

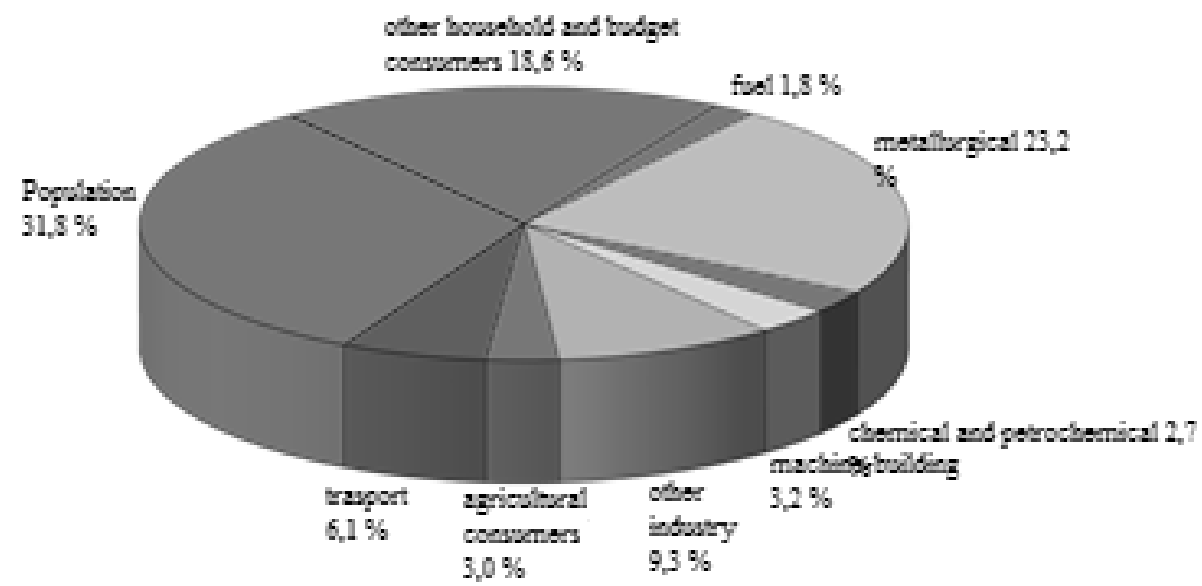

Figure 5.14. Structure of electricity consumption in Ukraine in $\mathbf{2 0 1 5}$

Source: New energy strategy of Ukraine until 2035 "Security, efficiency, competitiveness"

It is expected to achieve significant results in the first place which is to reduce region's energy dependence, reduction of industrial products consumption and the reduction of energy consumption in budget institutions of the region; the formation of enterprise producers of alternative fuels and energy efficient equipment.

Table 5.3. Objectives and possible scope of energy development programme in Cherkasy region

\begin{tabular}{|c|c|}
\hline Possible areas of projects/programmes implementation & Implementtion indicators \\
\hline $\begin{array}{l}\text { Ensuring access to technologies of alternative energy } \\
\text { sources use. } \\
\text { The creation of a data bank of the land suitable for } \\
\text { placement of alternative energy facilities according to its } \\
\text { types. } \\
\text { Implementation of projects of small hydropower and } \\
\text { bioenergy in particular in rural areas (e.g. planting of energy } \\
\text { crops). } \\
\text { Information campaigns among the population about the } \\
\text { feasibility and cost effectiveness of alternative fuels. } \\
\text { Installation of heating and water heating in the public sector } \\
\text { institutions that operate on renewable energy sources and } \\
\text { alternative fuels. } \\
\text { The introduction of recycling of solid waste for the } \\
\text { secondary use. } \\
\text { The use of energy efficient technologies in public utility } \\
\text { enterprises and budgetary institutions of local communities, } \\
\text { including transition of boilers on the alternative fuels (straw, } \\
\text { sawdust, pellets,etc.), thermal modernization of buildings } \\
\text { and other activities. }\end{array}$ & $\begin{array}{l}\text { - the number of implemented } \\
\text { energy efficiency projects; } \\
\text { - the number of boilers operating } \\
\text { on the alternative fuel; } \\
\text { - volume and dynamics of the fuel } \\
\text { and energy resources consumption } \\
\text { in public sector institutions; } \\
\text { - the proportion of substituted } \\
\text { imported natural gas in the } \\
\text { reconstructed heat supply systems; } \\
\text { - the percentage of heat losses in } \\
\text { main network after their } \\
\text { optimization; bns of budgetary } \\
\text { - the share of } \\
\text { institutions, which are heated by } \\
\text { natural gas with alternative fuels; } \\
\text { - the production of electric energy } \\
\text { from nontraditional renewable } \\
\text { sources of energy. }\end{array}$ \\
\hline
\end{tabular}

Source: compiled by the authors based on"The state strategy of regional development of the Cherkasy region for the period till 2020" 
One of the ways to solve power hunger in Cherkasy region is the introduction of alternative energy sources. According to the Association "Ukrhydroenergo" under favorable investment conditions Ukraine has the opportunity to receive an additional $2000 \mathrm{MW}$ of installed power maneuvering by the reborn and newly constructed small hydro power plants. There are about 30 private companies investing in renewable energy in Ukraine in 2016. The largest of them include VEA "Novosvit", LTD "Energoinvest" and others. Investments were directed mainly in Vinnytsia, Cherkasy, Khmelnytsky, Ternopil and Zhytomyr regions. Stoyan A. Yu. (2015) noted that there is $64 \%$ of the total number of stations, while the technical hydro potential of small rivers in these areas is only $14 \%$ of the total

Since 2001 the small hydropower has been restored. The Ukrainian energy consortium, later reorganized into the external economic Association "Novosvit" (Vinnytsia) and the Cherkasy branch (VEA "Novosvit") are the main contractors of the small hydropower restoration. For 15 years on small rivers of the region the reconstruction has been done and the work has been rnewed in Hordashivska, Zvenigorodka, Korsun ' -Shevchenkivsky, Lotashivska, Lysianska, Steblevskia hydro power stations and a new Korsun-Shevchenko mini-hydro sttion was built. The total capacity of hydropower plants (together with Kanev HPS) is $449.7 \mathrm{MW}$ or $58 \%$ of the total capacity of all power plants in the region (774.5 MW). During the year they produce 17.3 million $\mathrm{kW}$ per hour of electricity or $56 \%$ of the region's total production, equivalent to 6 thousand tons of fuel equivalent. The location of power generating facilities in Cherkasy region taking into account small HPSs is shown in Fig.5.15.

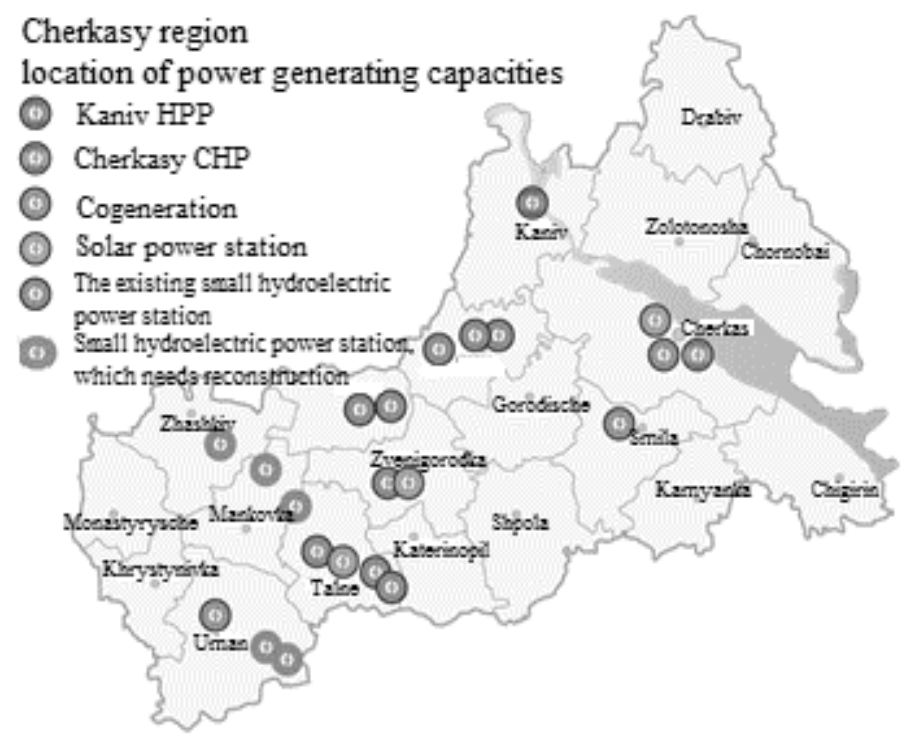

Figure 5.15. Location map of power generating capacity in the Cherkasy region Source: developed by the authors based on :http://ua.convdocs.org/docs/index-240493.html

The terrain drops in the zone, adjacent to small rivers, are very small. That is why the construction of hydroelectric power plants with a capacity of $10 \mathrm{MW}$ is inappropriate due to the potential flooding of large areas of farmlands. Therefore, in the region from an economic point of view it is advisable to create small hydropower facilities with a capacity of $10 \mathrm{MW}$.

Despite the fact that the Cherkasy region today is among the top five regions of Ukraine (Vinnytsia, Zhytomyr, Khmelnytsky and Ternopil) in the number of operating small hydropower plants, today the contribution of small hydropower plants in the region's energy is 
rather insignificant - about $1 \%$ of the total production and more than $22 \mathrm{mln}$. $\mathrm{kW} / \mathrm{h}$ of ecologically clean electricity per year. Their assistance is felt in the morning and evening hours when the load on the electricity network is significantly growing. In general, the hydropower potential of the region amounts to $219 \mathrm{~kW} / \mathrm{h}$. The use of such power will promote a socio-economic development of the region and will enable the production of additional electricity. However, the construction of HPS reservoirs is connected with a large influence on landforms, climate and human activities in the flooding areas. Economic impacts of creating reservoirs can be assessed with the two different types of costs. The first is the cost necessary for compensation of the damage when it is impossible to avoid. The second is the costs of tools designed to prevent or limit the anticipated negative effects of construction. The negative environmental impacts from the construction of new small hydropower plants or their reconstructions related to changes in the hydrological regime small and medium-sized rivers are rather substantial. Global climatic changes lead to considerable temperature fluctuations and disturbance of the water balance of the rivers, which requires additional study of the long-awaited environmental impact of construction of new small hydropower plants, but the investors of such projects are not interested in it.

From an environmental point of view (Zagoruiko N. V. \&Portyanko K. P., 2016), a significant regulation of medium and small rivers of Cherkasy region, decrease of precipitation and disturbance of the hydrological regime of rivers due to the rehabilitation and construction of new small hydropower plants are unjustified in comparison with the solution of the energy problems of the region and leads to the excessive anthropogenic pressures and the creation of ecological tension in the region. Biofuels is an important reserve for the energy resources replenishmnet. Biofuels is produced from oilseeds, such as sunflower, canola, corn and others. This unconventional type of environmentally friendly fuel during combustion hardlyt emits harmful gases. For the biofuel production it is necessary to provide high yields of oil crops through the rational use of natural-climatic conditions of certain areas, highquality seed that has high oil content, the introduction of advanced agro-technical measures. The districts included in the Steppe region have significant opportunities to obtain high yields and gross sunflowers and corn harvest. This may be the basis for the large-scale biofuel production and use. Cherkasy region refers to the regions of Ukraine with the predominantly agricultural areas of the economy (Petkova L., Khomenko E., Zagoruyko N., 2018). That is why, in the Cherkassy region, in addition to works on renewable small hydropower plants, the production of alternative fuels, the production of which are increasing every year. Farmers in the region are adopting new technologies for the profit in the production and sales of biofuels (table 5.4).

The capacity of these enterprises is quite promising for the sustainable development of the region. The development of this segment on the alternative energy sources gives much greater opportunities for local communities than the restoration of small hydropower plants in the region.

Ukraine has a clear policy of obtaining energy independence by adopting a national action plan for energy efficiency for the period up to 2020., the goal of which is reducing domestic final energy consumption in 2020 by $9 \%$. For Ukraine, the issue of efficiency is relevant in connection with a high level of energy intensity of GDP, which is 2.5-3 times higher compared to most EU countries (Program of energy independence and power sector reforms, 2017). The main reasons of this state is both a deterioration of the financiallytechnical base of industrial enterprises and the inefficient consumption of fuel and energy resources and inadequate technical condition of the overwhelming majority of existing buildings and energy systems. 
Table 5.4. Biofuel production by farmers in Cherkasy region in 2016

\begin{tabular}{|l|c|c|}
\hline \multicolumn{1}{|c|}{ Farm } & Biofuels & Production volumes (t) \\
\hline ALLP "Urozhai" & straw pellets & 237 \\
\hline PE Transbiofuel & wood waste & 982 \\
\hline LLP "Aver -Tech" & wood waste pelletes & 2130 \\
\hline PE Swan V. P. & solid biofuels from grain husks & 40 \\
\hline LLP "Khrystynivka - foodstuffs" & briquettes of sunflower husk & 907 \\
\hline PJSC "Chernobayevskiy plant food" & sunflower husk pelletes & 11 \\
\hline IE Tkachenko S. A. & sawdust briquettes & 72 \\
\hline IE Gorbach O. G. & straw pellets & 135 \\
\hline LLP "Urochysche Zhuravs'ke" & sunflower husk pelletes & 40 \\
\hline IE Marchenko G. & sunflower husk pelletes & 25 \\
\hline
\end{tabular}

Source: developed by the authors based on open data

The problem of increasing of the energy efficiency level is not new for Ukraine as a whole and for each region in particular. Ukraine, having accepted a number of commitments to the IMF to increase tariffs for housing and communal services and the establishment of market prices for energy should implement energy conservation measures and energy efficiency. For the population these measures are:

- conducting energy audits of residential houses and $100 \%$ installation of metering devices, which will allow to identify problems of housing, to form a plan of measures to improve energy efficiency, identify cost and payback period;

- maximum reduction of heat loss (replacement of windows, insulation of walls and ceilings);

- implementation of the heating system modernization and installation of automatic temperature controllers in heat exchangers and/or panels for apartment buildings;

- installing energy efficient equipment and its efficient use.

In recent years, one of the sources of financing of energy efficient measures is the state budget. So, starting in October 2014 and today the country has a program "warm credits", which is implemented by the State Agency on energy efficiency and energy saving of Ukraine. The programme principle is to compensate the amount of loan taken in the Bankpartner by the Government for the purchase of energy efficient equipment and materials. The goal of the program is to promote the implementation of energy efficiency measures in the homes, providing people with irrevocable cash assistance. The latter is available from the state banks - "Oschadbank", "Ukrgasbank", "Ukreximbank" in the amount of:

$-20 \%$ non-refundable assistance for the replacement of gas boilers for the population (but not more than 12 thousand $\mathrm{UAH}$ ). Any person may receive a loan for the purchase of the boiler with the reimbursement of part of its value via state bank institutions;

$-35 \%$ for individuals on the implementation of energy efficiency measures (but not more than 14 thousand UAH.): insulation of houses, replacement of metering of water and thermal energy, the windows installation;

$-40 \%$ for condominiums and housing cooperatives as legal entities, to conduct a thermo-modernization (but not more than 14 thousand UAH. per apartment);

- up to $70 \%$ for grantees that are members of the Municipal Public Institution.

Citizens have the opportunity to receive partial reimbursement on energy efficiency measures not only from the state budget, but also 15-20\% from the regional and city budgets. Now in Ukraine there are 204 local programs to reduce the cost of "warm" loans. Simultaneous compensation of energy efficiency measures from the state and local budgets 
helps to increase the amount of compensation to $45 \%$ of the project cost and reduce the payback period of most energy efficiency measures. Since the beginning of the program (Program of energy independence and power sector reforms, 2017) through three state-owned banks about 164 thousand credits for the sum of 2.7 billion UAH were issued. Totally, the "warm" loans served 214 thousand families who live in both individual and multi-apartment buildings.

An international project "Local development, oriented on the community" provides a significant assistance to local communities on energy issues. It has been operating in Ukraine since 2008. All initiatives are successfully implemented through the combined efforts of local residents, local, district and regional authorities, sponsors and initiators of the project, European donors. The communities ' contribution to the project is only 5\%. For example, in Cherkasy region, the first phase of the project, which took place from 2008 to 2011 , covered 8 districts with 54 implemented micro-projects. In the second phase, which lasted from 2011 to 2014, 13 districts were involved with 69 implemented micro-projects. The third phase is currently in operation, which began in 2014 and should last until 2018. Within each phase millions UAH have been spent. At the beginning of the project the rural community must create a non-profit public organization and then determine the greatest challenges. Most applications were on the energy efficiency theme in schools, health care establishmnets, street lighting and repair, water supply systems in local communities.

Thus, Ukraine has a state support of the population for the implementation of energy saving programmes at the level of soft loans for citizens, which are widely used by individual citizens, state and municipal institutions. Rural communities do not fully use the opportunities of attracting funds of international organizations to solve local problems. An international project "Local development, oriented on community" provides a considerable assistance, but to participate in the project the rural community must create a non-profit public organization and then define the greatest challenges. The population do not have enough experience.

The solution to the problem of energy saving in Ukraine through alternative sources of energy is encouraged by the state. Small hydro energy development in this direction is problematic for the central regions, since the effects of global warming lead to the decrease in precipitation and disturbance of the hydrological regime in Central Ukraine. As a result of these processes the existence of small and medium rivers become at risk. Central regions of Ukraine belong to the agrarian-industrial type. Cherkassy region receives more than $50 \%$ of the profits through the export of agricultural products. The alternative fuels from green mass are a promissing technology.

\section{References:}

New energy strategy of Ukraine by 2035 "Security, efficiency, competitiveness". Avaliable at: https://zakon.rada.gov.ua.

Petkova, L., Khomenko, E., Zagoruyko N. (2018). Analysis of the perspectives of international environmental cooperation for the central regions of Ukraine. EUREKA: Social and Humanities. No. 1, 23-38.

Program of energy independence and power sector reforms - 2017. Avaliable at: https://reformsguide.org.ua

Program to improve energy efficiency and reduce energy consumption in Cherkasy region in 2011-2015 (Extended to 31.12.2017 decision No. 10-9/VII dated 16.12.2016) Avaliable at: https://: www.oblradack.gov.ua. 
Regional programme on the small hydropower development in the Cherkasy region for 2011 2020 (2011). Avaliable at: http://ua.convdocs.org/docs/index-240493.html

Review of the implementation of the main provisions of the Kyoto Protocol to the UN framework Convention on climate change and commitments of OECD and EU regarding the implementation of the recommendations of the Paris Conference Kiev-07/2017. Avaliable at: https://ua.energy/wp-content/uploads/2017/05/3.-Osn_polozh_SOR21.pdf

Stoyan, A. Yu. (2015). Research on small hydropower development in Ukraine: features, tendencies, energy potential. Investments: practice and experience. No. 3, 116-120.

The state strategy of regional development of the Cherkasy region for the period till 2020 (2015). Avaliable at: https://www.ck-oda.gov.ua/docs/2015/01072015_econom.pdf

Ukraine and policy of climate change: the economic aspect (2016). The analytical report of the Razumkov Center, according to BP Statistical Review of World Energy" Kiev: Razumkov Center.

Zagoruiko, N. V., Portyanko, K. P. (2016).Assessment of environmental risks from the construction of new small hydropower plants in Cherkasy region. $V$ international scientific conference of young scientists "Ecology, neoecology, environmental protection and balanced nature". Kharkiv: KHAU after Karazin.

\subsection{FINANCIAL AND INTEGRATED REPORTING AS A TOOL FOR DISPLAYING INFORMATION ABOUT THE RESULTS OF INVESTMENT AND INNOVATION DEVELOPMENT OF ENTERPRISES IN THE NATIONAL AND GLOBAL BUSINESS ENVIRONMENT}

\section{Iryna Vasylchuk}

Doctor of Economics Sciencies, Associate Professor, Professor of the Finance, Banking and Insuarance Department,

Kryvyi Rih Economic Institute of Kyiv National Economic University named after Vadym Hetman, Kryvyi Rih, Ukraine

Yaroslav Izmaylov

PhD (Economics), Associate Professor,

Associate Professor of the International Economics Department,

Kryvyi Rih Economic Institute of Kyiv National Economic University named after Vadym

Hetman, Kryvyi Rih, Ukraine

\section{Kateryna Slyusarenko}

PhD (Economics), Associate Professor,

Head of the International Economics Department,

Kryvyi Rih Economic Institute of Kyiv National Economic University named after Vadym

Hetman, Kryvyi Rih, Ukraine

Jowita Ziołek-Barczak

MA, Polonia University in Czestochowa, Poland

Gaining importance of the strategic resource, information becomes a priority in the process of company management and ensuring the competitive advantages of the companies in national and global business environment.

Under current conditions the role of companies reporting is increasing and its value is determined by the information requests of internal and external users. Economic indicators of 
economic activity of Ukrainian companies are represened in financial, internal economic, tax and statistical reporting. The task of reporting and analyzing the represented indicators is the multidimensional measurement and interpretation of individual processes of the company economic activity and assessment of the value of its economic resources. The system of financial reporting remains relevant for receiving and further analytical processing of important financial information concerning the activities of business entities in industrial society. At the same time, in today's post-industrialized globalized world, it is not enough for companies to obtain economic effect only. After all, the attractiveness of a business entity is determined by the focus on innovation and the solution of social and environmental problems. For the postindustrial world economy, integrated non-financial reporting becomes increasingly important.

The current world trend is the formation of an integrated reporting mechanism that includes information on the sustainable development of the economic, social and environmental systems of companies. At the climate conference held in Paris in 2015, it was determined that the basis of sustainable development reporting is the information on accounting and economic analysis systems of companies. Realizing the urgent need for further improvement of reporting, the Global Reporting Initiative announced the launch of a new "Reporting 2025" project ("Reporting 2025") aimed at encouraging an international debates on the future disclosure of information.

Timely and accurate submission of data on investment and innovation activity, social responsibility, protection of the environment, measures for its restoration, safety of manufactured products for man and the environment open the possibility of company entering world markets, give opportunity to employ the most skilled personnel, increase capitalization, goodwill, reputation and image of the company. It is worth emphasizing that the information on innovations, production modernization, social and environmental activities of the company is mandatory for disclosure in accordance with the requirements of the international standards of social activity and reporting "Global Reporting Initiative (hereinafter GRI)", "Integrated reporting (hereinafter referred to as IR)","ISO 26000").

The compilation of integrated reporting enables economic entities in Ukraine to increase significantly the transparency of their economic, investment, innovation, social, environmental and social activities. The interested legal entities and individuals will be able to obtain information on the strategy of company development, investment, innovation, social responsibility, environmental safety, etc. Integrated reporting is provided by well-known multinational corporations such as Ford, Johnson \& Johnson, Shell, Disney, Procter \& Gamble, Vodafone, Xerox, Microsoft, Cisco, HP, Siemens, BASF, Soka-Cola, ArcelorMittal, Novartis, Carrefour, Nokia, HSBC, Novo Nordisk. In Ukraine companies that have a great influence on socio-economic development and have a responsibility to society publish their integrated reporting. Among them the most famous are System Capital Management, DTEK, PJSC Obolon, Nestle Ukraine, Kyivstar, SUN InBev Ukraine, Vidi Group, Life and others).

The submission of integrated reporting on the basis of sustainable development is not popular in Ukraine. The reasons for it are the owners aiming mostly at increasing company profit and an obscure state policy that does not support socially-oriented business, does not orient the business entities, society and public organizations to operate on the principles of sustainable development. Reporting, which is based on the principles of sustainable development, at this stage of growth of the Ukrainian economy is non-financial. However, it is gaining in popularity. Therefore, a systematic review of non-financial reporting on the principles of sustainable development with its prospects, positive and negative consequences for Ukrainian business entities is one of the important issues of economic science that requires urgent solution. The need for an in-depth study of the theoretical foundations for the formation and display of 
integrated reporting on the basis of sustainable development, the solution of the main issues of the practical application of methodological approaches and ensuring the adequacy of the content of such reports, determine the relevance of the study, which is covered in this study.

Great attention is paid to the search for opportunities to improve reporting as one of the key factors for making managerial decisions on the effective use and placement of capital and other social and productive factors of leading domestic scientists in various branches of the economy. Theoretical and methodological problems of formation and representimg financial information reporting have been studied in the works of famous domestic scientists and economists such as: M. T. Bilukha, F. F. Butynets, B. I. Valuev, M. Ya. Demyanenko, K. P. Dudka, V. I. Efimenko, V. M. Juck, G. G. Kireitsev， M. V. Kuzhelnyj, V. G. Linnyk, V. B. Mossakovsky, M. F. Ohiychuk, P. T. Sabluk, S. V. Svirko, V. V. Sopko, N. M. Tkachenko, M. G. Chumachenko, P. Ya. Khomina, L. S. Shatkovskaya et al. A significant contribution to the solution of these problems was made by foreign scientists: N. A. Breslavtseva, O. V. Efimova, V. V. Kovalev, A. P. Mihalkevich, V. D. Novodvorsky, V. F. Paliy, Ya. V. Sokolov, A. N. Horin, L. A. Bernstein, M. F. Van Breda, G. A. Welsh, D. Coldwell, B. Needls, E. S. Hendrixen, A. D. Sheremet et al.

S. M. Petrenko and V. O. Bessarabov (2015) proposed a model of socially-oriented accounting, which is based on the creation of a local accounting section using the system of analytical accounts for social responsibility expenditures. It includes three components: organizational, methodological and technical ones.

K. V. Bezverhyi (2016) proposed representing company employees' alaries and wages overdue accounts, and placed emphasis on the socially-oriented indicators in the reporting.

V. Evdokimov, D. Gritsyshyn, O. Gryshchenko and O. Baryshnikov (2013) characterize the current state of social reporting in Ukraine and describe the international models of social reporting in the world. T. Butinets (2012) and Zhigley (2010) consider the accounting of socially responsible activities in their scientific works.

Russian scientist T. Solovey (2014) in his scientific work makes an attempt to improve the process of financial reporting of a socially active company. A. Shokhina (2006) also studied the practice of social reporting.

R. J. Eccles and S. A. Dipiazza (2003) require the introduction of new World Financial Reporting Standards with the expansion of their general framework by sectoral and corporate standards, which should solve most of the problems of IFRS.

Professor S. V. Svirko (2015) grounded firmly that the most effective mechanism for regulating sustainable development reporting is the Global Reporting Initiative (GRI) protocols, which define a set of indicators that characterize the social, environmental and economic components of the economic activity of an industrial company. The use of the entire set of protocols of the Global Reporting Initiative requires the modification of certain components of the organization and accounting methodology, which serves as the main means of informational support for the formation of sustainable development reporting.

Supporting the opinion of S. F. Golov (2009), we believe that the transition from the concept of financial reporting to the concept of corporate reporting is necessary to reflect such issues as a retrospective and perspective information about the activities of the company and its environment; strategic and current aspects of the company's activity based on the balance of long-term and short-term, financial and non-financial indicators; structured information taking into account the requests of relevant users.

Having critically analyzed publications on relevant topics, it is worth noting that the issues of development of integrated reporting remain inadequate. In addition, in today's environment there are no clear normative general recommendations and issues of accounting 
and clear information on integrated reporting of companies is not provided sufficiently. It should be emphasized that various aspects of innovative activity and life cycle of innovations fall within the scope of practically all national and international financial reporting standards. At the same time, the financial statements do not foresee the reflection and selection of the results of investments, innovations, social and environmental indicators. There is also an important problem of information generation for the statistical study of macroeconomic processes, which should be the basis for accounting of business entities. It is a task of utmost importance to prove the necessity for integrated reporting by Ukrainian enterprises and to improve the process of forming the main indicators of integrated reporting on the basis of sustainable development for the purpose of assessing investment and innovation, environmental and socio-economic indicators of economic entities with recommendations for providing information on calculations of macroeconomic indicators at national and global business environment.

The post-industrial economy puts forward new approaches, queries and tasks to the accounting and reporting system. It affects the development of accounting as a science, changing the subject and forcing to improve its principles and organization. Formation and synthesis of information on the activities of business entities on the basis of sustainable development at this stage of the functioning of the Ukrainian economy can make a significant contribution to the transformation of information flows between internal and external users of electronic databases of accounting and reporting data.

The development of the global market for investments and innovations, the negative impact of business entities on the environment and social instability require creation of a mechanism for information management of economic systems of all levels based on the principles of sustainable development. In order to consider in detail the reporting based on the principles of sustainable development and to establish synergism between the principles of reporting and sustainable development, the primary task is to define and substantiate the theoretical basis (Table 5.5).

Table 5.5. Elucidation of the essence of sustainable development of the company as a state and process

\begin{tabular}{|c|l|}
\hline Approach & \multicolumn{1}{c|}{ Definition } \\
\hline $\begin{array}{c}\text { Sustainable } \\
\text { development } \\
\text { as a state }\end{array}$ & $\begin{array}{l}\text { It is the state of the socio-ecological and economic system of the company } \\
\text { characterized by harmonization of social, ecological and economic goals of the } \\
\text { company and meeting the needs of all social relations participants which are } \\
\text { influenced by the economic activity of the, company giving opportunity to ensure } \\
\text { the interests of contemporary and future generations. }\end{array}$ \\
\hline $\begin{array}{c}\text { Sustainable } \\
\text { development } \\
\text { as a process }\end{array}$ & $\begin{array}{l}\text { is a process of transforming the socio-ecological and economic system of the } \\
\text { company and / or maintaining it in a state characterized by harmonization of the } \\
\text { social, ecological and economic goals of the company and meeting the needs of all } \\
\text { social relations participants which are infused by the economic activity of the } \\
\text { company giving opportunity to ensure the interests of contemporary and future } \\
\text { generations. }\end{array}$ \\
\hline
\end{tabular}

Source: compiled by authors based on Gritsyshen D.O., 2015.

The accounting process is completed by compiling financial statements about company business activities of the egal basis for the preparation and submission of financial statements is regulated by the Law of Ukraine "On Accounting and Financial Reporting in Ukraine", as well as by the Accounting Standards (Accounting Standards). The provisions of this Law and the Regulation should be applied to the financial statements of companies, organizations and other legal entities of all the forms of ownership, regardless of their organizational and legal types and 
forms of ownership. The new wording of the Law of Ukraine "About Accounting and Financial Reporting in Ukraine" (1999) states that financial statements are statements that contain information on the financial position and performance of the enterprise. The purpose of preparing financial statements is to provide users with complete, truthful and unbiased information about the financial position, performance and cash flow of the company for making their decisions. A management report that contains financial and non-financial information characterizing the state and prospects of company development and revealing the main risks and uncertainties in its activities is introduced legally.In accordance with the International Standard Integrated Report, issued in December 2013 by the International Council for Integrated Reporting (IIRC), integrated reporting is treated as an integrated thinking process that results in a periodic integrated report of the company on creation of value for a long time and related documents related to aspects of value creation. The Integrated Report is a brief summary of the impact on the creation of value for performance, strategy and management of the organization. To define of the concept of "integrated reporting" contained in the works of scholars, it is rational to group together seven basic approaches, Fig. 5.16.

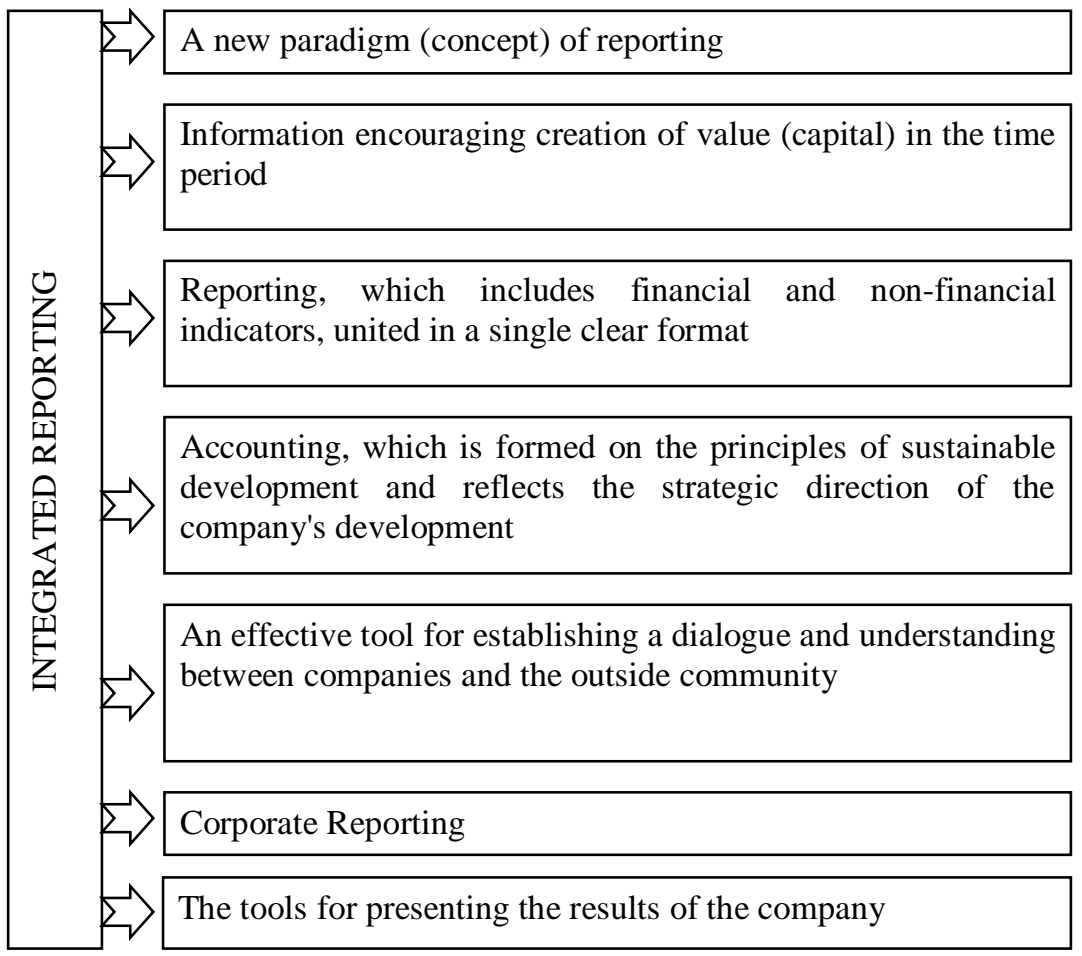

Figure5.16. The concept of "integrated reporting" in the works of scholars Source: compiled by authors based on Bezverkhyi K. V., 2015

According to the author (Bezverkhyi K. V., 2015), integrated reporting should be understood as reporting that combines, in a clear format, financial and non-financial indicators that affect the creation of value (capital) and reflect the strategic direction of the company's development on the basis of sustainable development.Preparation of integrated reporting on the basis of sustainable development requires improvement of the system of organization of accounting, analysis, control, planning and management in the company through the development of information of direct and feedback flows. The management of the company 
should clearly define the list of issues and indicators to be represented determine the way in which information is represnted and how to respond to requests from external and internal users. When reporting companies' activities, it is necessary to balance the needs of the main groups of users of information. At the same time, reporting should be performed in accordance with the established principles of IFRS, N(S)A and Sustainable Development.Fig. 5.17 provides the main structural elements and components of integrated reporting taking into account the private or state ownership, sectoral, accounting and other features of economic entities. They can be based on the company management vision of reporting in view of specific features and reveal presentation of structural components in more detailed way.

\begin{tabular}{|c|c|c|}
\hline $\begin{array}{c}\text { Review of company economic } \\
\text { activity and its environment }\end{array}$ & $\begin{array}{c}\text { Organizational structure } \\
\text { and business model }\end{array}$ & $\begin{array}{c}\text { Strategy and resources } \\
\text { allocation }\end{array}$ \\
\hline $\begin{array}{c}\text { Main principles of representing } \\
\text { information }\end{array}$ & Risks and opportunities & $\begin{array}{c}\text { Corporate } \\
\text { management }\end{array}$ \\
\hline Results of activity & \multicolumn{2}{|c|}{ Future prospects } \\
\hline
\end{tabular}

\begin{tabular}{|c|c|c|c|}
\hline \multicolumn{3}{|c|}{ Structural components } \\
\hline $\begin{array}{c}\text { Financial } \\
\text { Statements }\end{array}$ & $\begin{array}{c}\text { Reporting on Sustai- } \\
\text { nable Development }\end{array}$ & $\begin{array}{c}\text { Reporting on Corporate } \\
\text { Management }\end{array}$ & $\begin{array}{c}\text { Management } \\
\text { Notes }\end{array}$ \\
\hline
\end{tabular}

FUNCTIONS

Informational; communicational; integrational; adaptive-stimulating; scientific and cognitive ones

\begin{tabular}{|c|c|}
\hline $\begin{array}{l}\text { POSITIVE Results of representing information } \\
\text { RESULTS }\end{array}$ & $\begin{array}{r}\text { NEGA } \\
\text { RESL }\end{array}$ \\
\hline $\begin{array}{l}\text { For the company: Improving of the quality of corporate } \\
\text { management; Increasing of investment and innovation } \\
\text { attractiveness; Increasing in the share price of the } \\
\text { company; Broader prospect of company activity } \\
\text { attracting potential counterparties and shareholders; } \\
\text { Minimization of operational risks; Providing objective } \\
\text { and reliable information for a wide range of users; Image } \\
\text { enhancement, growth of competitive advantages and } \\
\text { company loyalty; Ensuring social responsibility and } \\
\text { environmental safety. } \\
\text { For external environment: Information transparency, } \\
\text { increasing the responsibility of business for economic, } \\
\text { social and environmental components; Creation of a } \\
\text { favorable investment and innovation climate; Reducing } \\
\text { corruption and reshoring of the economics. }\end{array}$ & $\begin{array}{l}\text { The doubts } \\
\text { concerning the } \\
\text { reliability of data } \\
\text { due to } \\
\text { underdeveloped } \\
\text { accounting } \\
\text { system based on } \\
\text { the principles of } \\
\text { sustainable } \\
\text { development; } \\
\text { Legal risks } \\
\text { related to the } \\
\text { normative } \\
\text { requirements of } \\
\text { regulators to } \\
\text { reporting }\end{array}$ \\
\hline
\end{tabular}

Figure5.17. Ingredients of Integrated Reporting of the Enterprise as a Tool for Displaying Information on Investment and Innovation Development in the National Source: developed by the authors and Global Business Environment 
Integrated reporting involves the following sections of thecompany:

Section 1. The general section (review of the company economic activity and its external environment), in which it is necessary to provide information on the organizational and legal form of ownership, activities, strategic vision in the short, medium and long-term periods of development of the economic, ecological and social components of thecompany in the national and global business environment.

Section 2. Basic presentation principles in which it is appropriate to assess the approaches determining the main essence and frames of the reporting in relation to the standards and principles used in it.

Section 3.Strategy and resource allocation, in which it is recommended to provide brief information on the development strategies of the company and explaining all types of capital (other resources).

Section 4. Organizational structure and business model of the company, containing information about thecompany structure and the mechanism for implementing the strategy of business model of company development.

Section 5.Corporate management, representing information about corporate management, entities and objects of control over the implementation of the company development strategy.

Section 6. Risks and opportunities, where it is recommended to reveal information about the existence of an effective system for identifying and preventing risks at the company with the possibility of finding development reserves.

Section 7. Results of activity, representing information about the results of company economic activity with obligatory indication of the resulting impact on types of capital (cost). It is also necessary to provide a description of the efficiency and effectiveness of the development strategy and company business model.

Section 8. Prospects for the future, representing information about the initiatives and strategic intentions of the company in future periods, taking into account already achieved results. Particular attention should be paid to eliminating the negative results of the company's business development ith the determination and minimization of the influence of the factors having led to them.

In contrast to the financial statements, purposing to the formation of retrospective information on the state, formation and use of business assets, the main feature of integrated reporting is the focus on the intellectual, financial, industrial, natural, social and human resources of the company in terms of the creation of value (capital). The problem of the absence of the above group of non-financial indicators in the mandatory financial statements of economic entities is solved precisely by non-financial reporting with individual development of the methods of reflection and drawing up of economic, social and environmental components by each economic entity. These methodological features are recommended in the accounting policies of the business.

The main important task of compiling integrated reporting is to reflect information on types of value (capital) of a business conveniently and correctly, in particular, working, financial, human, intellectual, socially-reputational and natural capital. The resulting component of the model for creating the value (capital) of industrial company is presented in the form of indicators of types of capital (Table 5.6), which are presented in Section 7 of the integrated accounting of these entities. 
Table 5.6. Representing of integrated reporting information on the results of financial and economic activity on the basis of investment and innovation development of industrial company in the national and global business environment

\begin{tabular}{|c|c|c|}
\hline $\begin{array}{l}\text { Type of } \\
\text { capital } \\
\text { (value) }\end{array}$ & Essence & Indicators \\
\hline 1 & 2 & 3 \\
\hline 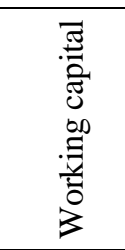 & $\begin{array}{l}\text { Physical objects (buildings, structures, } \\
\text { equipment, etc.) that are available and used } \\
\text { by the enterprise in the production process } \\
\text { (providing services) }\end{array}$ & $\begin{array}{l}\text { Volume of investment and innovation } \\
\text { resources; indicators for updating, using } \\
\text { and disposing of non-current assets; part of } \\
\text { high-tech equipment; the level of } \\
\text { computerization and informatization of } \\
\text { workplaces }\end{array}$ \\
\hline 㞼 & $\begin{array}{l}\text { Financial resources used by the company } \\
\text { in production process and giving profit. }\end{array}$ & $\begin{array}{l}\text { Created and distributed cost; increase in net } \\
\text { assets in terms of elements; profitability } \\
\text { (investments, production, etc.); the share of } \\
\text { domestic and foreign product market }\end{array}$ \\
\hline 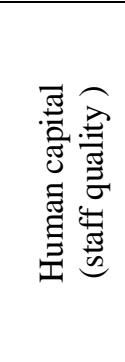 & $\begin{array}{l}\text { A set of skills and abilities of company } \\
\text { employees , including orientation to the } \\
\text { structure of company management and its } \\
\text { ethical values; the ability to understand and } \\
\text { implement the enterprise strategy, loyalty } \\
\text { and motivation to improve the work }\end{array}$ & $\begin{array}{l}\text { A number of employees, depending on the } \\
\text { qualifications; the level of wages and } \\
\text { salaries in terms of the main qualifications; } \\
\text { an increase in the average wages and its } \\
\text { relation to the average wages in the region } \\
\text { labor market; growth rate of labor } \\
\text { productivity; an increase in the cost of } \\
\text { training, education and staff training; the } \\
\text { rates of injuries and occupational diseases }\end{array}$ \\
\hline 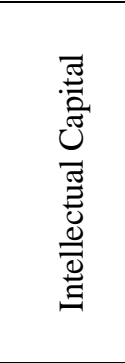 & $\begin{array}{l}\text { Created or acquired intellectual product } \\
\text { which is evaluated, objected and identified } \\
\text { (separated from the company) and } \\
\text { maintained by a business (entity) for the } \\
\text { purpose of obtaining profit (added value). } \\
\text { Intellectual capital is found in the } \\
\text { following forms: intellectual capital, } \\
\text { intellectual property, and intellectual } \\
\text { assets. }\end{array}$ & $\begin{array}{l}\text { Extension of know-how, industrial designs, } \\
\text { patents, etc.; number of developed } \\
\text { regulations; introduced } \\
\text { technologies and improved production } \\
\text { process; part of high-tech innovative } \\
\text { equipment in total }\end{array}$ \\
\hline 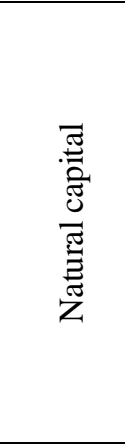 & $\begin{array}{l}\text { Natural resources (water, land, minerals, } \\
\text { forest, diverse ecosystems, etc.) used by } \\
\text { the company in economic activity or being } \\
\text { affected by the company in positive or } \\
\text { negative way. Information on these } \\
\text { resources is represented through } \\
\text { information on the company's impact on } \\
\text { the environment. }\end{array}$ & $\begin{array}{l}\text { Basic principles of the business entity } \\
\text { environmental policy; change (positive or } \\
\text { negative) in consumption of energy, water, } \\
\text { land use, etc.; growth of waste by hazard } \\
\text { classes; volumes of using and pollution of } \\
\text { water, land resources, atmospheric air; } \\
\text { introduction of new ecological and } \\
\text { resource-saving technologies, areas of re- } \\
\text { cultivated lands; fines and penalties } \\
\text { amounts for non-compliance with } \\
\text { environmental legislation }\end{array}$ \\
\hline
\end{tabular}


Continued tab5.6

\begin{tabular}{|l|l|l|}
\hline 1 & \multicolumn{1}{|c|}{2} & \multicolumn{1}{|c|}{3} \\
\hline & $\begin{array}{l}\text { Networking, established among groups of } \\
\text { stakeholders and relationship aimed at } \\
\text { improving individual and social well- } \\
\text { being. It includes values and behaviors; } \\
\text { basic relations; trust and loyalty that a } \\
\text { company has gained from its partners and } \\
\text { customers and which it wants to maintain; } \\
\text { product quality; growth of new jobs; } \\
\text { place of the company in the ratings } \\
\text { (branch, national, international, etc.); } \\
\text { stability of relations with contractors; the } \\
\text { amount of free assistance to the local } \\
\text { community and other regions }\end{array}$ \\
& $\begin{array}{l}\text { agreement of society on the activity of the } \\
\text { company. It is next to impossible to assess } \\
\text { socially-reputable capital in a cost- } \\
\text { effective way, clearly and directly. } \\
\text { Therefore, the information about it is } \\
\text { reflected in the non-financial part of the } \\
\text { integrated reporting, which details the } \\
\text { information about the company and its } \\
\text { social responsibility and activity. }\end{array}$ & \\
\end{tabular}

Source: developed by the authors

While mentioning the principles wemean the rules that should be guided by the measurement, evaluation, registration of business operations and the reflection of their results in the reporting. In developed business world integrated reporting is compiled and presented in various forms.

However, the main reporting regulatory models are those based on the principles of sustainable development, namely: GRI (Global Reporting Initiative), UN Global Compact, Sunshine Standard, AA1000, Equator Principles.

Presentation of integrated reportingcompiling on the principles of international reporting models, shown in Fig. 5.18. It allows improving the image, competitiveness and investmentinnovative attractiveness of Ukrainian business at the national and international levels, to form a positive attitude towards the management and owners of the community, etc.

For the preparation of high-quality integrated reporting by Ukrainian companies on the basis of sustainable development, the classification of principles grounded on acritical analysis of their effectiveness is proposed.

The list of principles is quite large. Therefore, it is proposed to use a more rational, structured approach to establishing the principles of reporting the economic activity of Ukrainian companies. The recommended specified list of principles provides their grouping into general (conditions, recommendations, restrictions) and special ones (information content, ensuring quality and process of reporting preparation).

Characteristics of general principles are provided in the Law of Ukraine "On Accounting and Financial Reporting". As for special principles, we are dwelling upon more detailed description of their characteristics in accordance with the conditions of the model of investment and innovation development of Ukrainian economy (Table 5.7). 


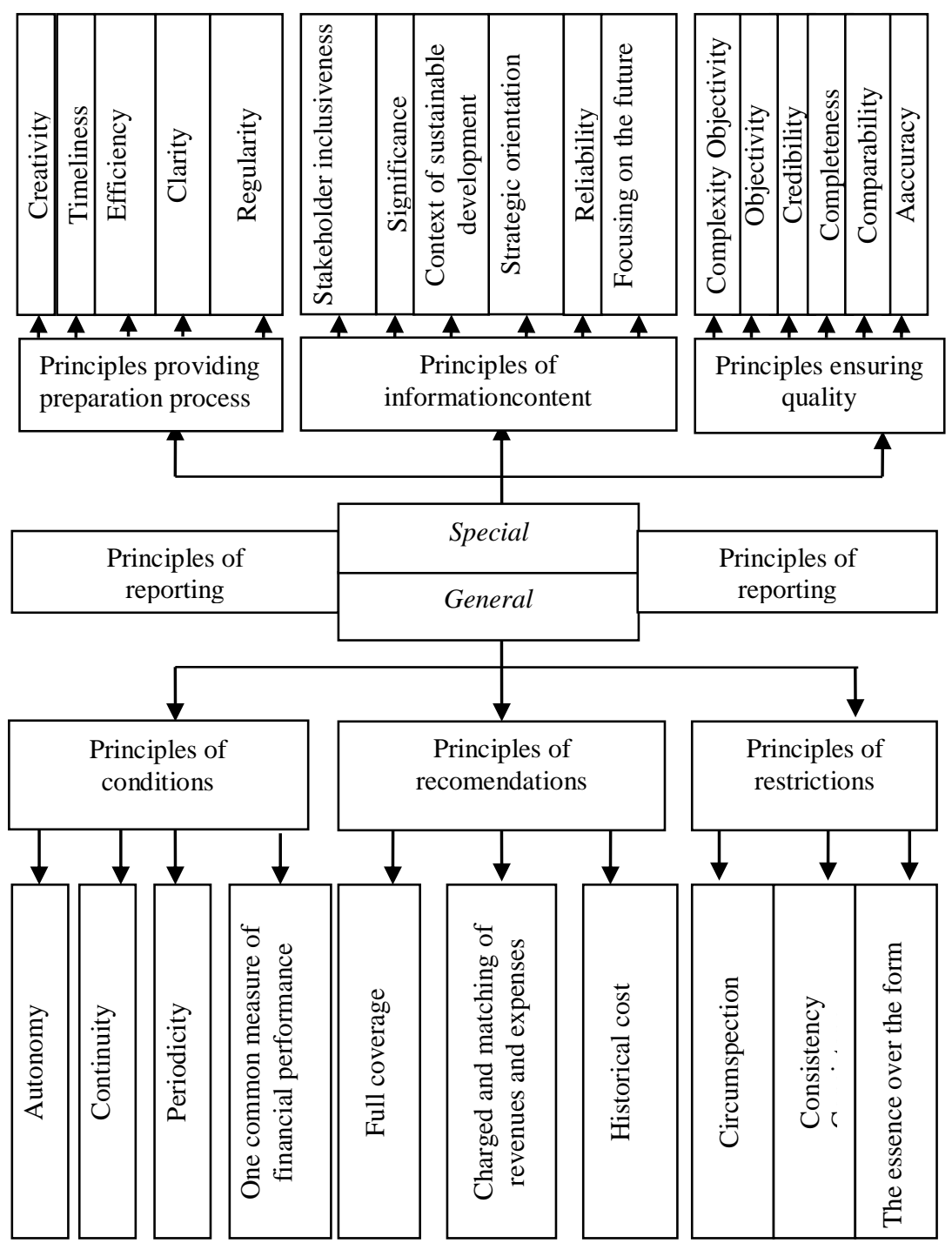

Figure 5.18. A system of reporting principles of Ukrainian companies working in the national and global business environment

Source: compiled by the authors

The recommended clarification of the content of these principles (table 5.7) allows high quality formation of reports for effective management of the company economic activity under the conditions of postindustrial development of the economy, attracting new investors, counteragents, forming a positive image of the company at micro, macro and mega-levels. Being based on the proposed principles, a business can formulate the content and structure of integrated reporting independently on the basis of sustainable development. 
Table 5.7. Recommended essence clarifyimg of special principles of the companies reporting under the conditions of investment and innovation development of Ukraine

\begin{tabular}{|c|c|}
\hline Principle & Essence \\
\hline 1 & 2 \\
\hline & PRINCIPLES OF INFORMATION CONTENT \\
\hline $\begin{array}{l}\text { Stakeholders } \\
\text { inclusiveness }\end{array}$ & $\begin{array}{l}\text { Companies should ensure proper understanding of stakeholders needs providing } \\
\text { information on economic, environmental and social activities, and explaining in } \\
\text { the report how their interests and expectations have been taken into account } \\
\text { during its preparation. }\end{array}$ \\
\hline $\begin{array}{l}\text { Sustainability } \\
\text { context }\end{array}$ & $\begin{array}{l}\text { A company should reveal information about the results of its activities not } \\
\text { separately, but in context, taking into account the requirements and restrictions } \\
\text { on the use of economic, environmental and social resources at micro-, macro-, } \\
\text { and mega-levels. }\end{array}$ \\
\hline Materiality & $\begin{array}{l}\text { The reporting should include indicators having a significant impact on the } \\
\text { assessments and decisions of external and internal stakeholders. The principle } \\
\text { differs in form and content for the requirements of financial and non-financial } \\
\text { reporting. In financial reporting materiality is considered to be a threshold of } \\
\text { influence on economic decisions of users of business reporting. In non-financial } \\
\text { reporting stakeholders consider the activities of the economic entity from } \\
\text { economic, social and environmental points of view. }\end{array}$ \\
\hline $\begin{array}{c}\text { Strategic } \\
\text { orientation }\end{array}$ & $\begin{array}{l}\text { The report provides information on strategic objectives of the business, its } \\
\text { resources and opportunities. }\end{array}$ \\
\hline Reliability & $\begin{array}{l}\text { Gives opportunity for stakeholders to verify the accuracy of its contents and the } \\
\text { adequacy of the application of the principles basing on the confirmity with initial } \\
\text { information. }\end{array}$ \\
\hline $\begin{array}{l}\text { Focusing on } \\
\text { the future }\end{array}$ & $\begin{array}{l}\text { The information represented in the report should indicate the vector of the } \\
\text { company development, key progress objectives and chalenges. }\end{array}$ \\
\hline $\begin{array}{l}\text { Scientific } \\
\text { knowledge }\end{array}$ & $\begin{array}{l}\text { The methodology of compilation and submission of reports is based on the latest } \\
\text { achievements of science, dependent on the effeciency of economic law, } \\
\text { influenced by objective reality of the functioning economic system and objective } \\
\text { factors changing and developing this system. }\end{array}$ \\
\hline \multicolumn{2}{|r|}{ PRINCIPLES ENSURING QUALITY OF THE REPORTING INFORMATION } \\
\hline Completeness & $\begin{array}{l}\text { The report should contain a sufficient number of indicators to provide complete } \\
\text { information on the economic, social and environmental components of business } \\
\text { entity, which enable stakeholders to assess the activities of the company during } \\
\text { the reporting period. Completeness includes scope, boundaries, and reporting } \\
\text { timeframe. }\end{array}$ \\
\hline Accuracy & $\begin{array}{l}\text { The information represented in the report must be precise and detailed } \\
\text { sufficiently so that stakeholders could assess the results of the company } \\
\text { activities. }\end{array}$ \\
\hline Comparability & $\begin{array}{l}\text { Reporting information should enable stakeholders to analyze the changes in } \\
\text { economic, social and environmental outcomes in order to compare indicators } \\
\text { with other busness entities }\end{array}$ \\
\hline Credibility & $\begin{array}{l}\text { Reporting should provide a true and complete picture of the property and } \\
\text { financial and economic condition of the company, as well as the results of its } \\
\text { activities. The reporting is credible and trustworthy, when it includes reliable, } \\
\text { substantiated data, characterized by lack of errors and can be acquired by users } \\
\text { correctly. }\end{array}$ \\
\hline
\end{tabular}




\begin{tabular}{|c|c|}
\hline 1 & 2 \\
\hline $\begin{array}{l}\text { Natural } \\
\text { non-financial } \\
\text { indicators }\end{array}$ & $\begin{array}{l}\text { Possibility of using natural measures in reporting, when it is practically impossible } \\
\text { to make a valuation in a cost-oriented manner. This information is recommended to } \\
\text { be represented in the non-financial part of the integrated reporting. }\end{array}$ \\
\hline Objectivity & $\begin{array}{l}\text { Reporting should reflect objective reality and be based on reliable information, not } \\
\text { on the subjective opinions of stakeholders. When interpreting data it is necessary to } \\
\text { take into account the influence of all factors and restrictions. The ideal option is to } \\
\text { use economic reporting data, which authenticity is confirmed by the auditor. }\end{array}$ \\
\hline \multicolumn{2}{|r|}{ PRINCIPLES PROVIDING THE PROCESS OF REPORTING PREPARATION } \\
\hline Clarity & $\begin{array}{l}\text { The information provided in the reporting must be represented in understandable and } \\
\text { comprehensible form, accessible to all the stakeholders, without excessive and } \\
\text { unnecessary details, the use of technical terms, abbreviations, professional jargon, etc. }\end{array}$ \\
\hline Balance & $\begin{array}{l}\text { Objective information can be obtained by presenting both positive and negative } \\
\text { results of the business activity in the reporting. The report must draw a clear line } \\
\text { between actual information and its interpretation from the company. }\end{array}$ \\
\hline Timeliness & $\begin{array}{l}\text { The reporting is compiled and represented according to a regular schedule, and the } \\
\text { provided information is available to stakeholders, in order to make managerial } \\
\text { decisions. The information contained in the report must be revealed within } \\
\text { specified time limits after the end of the reporting period. Collection and } \\
\text { publication of key information on the results of the company's activities are } \\
\text { consistent with the reporting schedule in the field of sustainable development. The } \\
\text { information in the reports is accompanied by a clear indication of the period it } \\
\text { belongs to, when it was formed and when the following information is expected }\end{array}$ \\
\hline Regularity & $\begin{array}{l}\text { Regularity requires the reporting of a certain system at specified intervals, for the } \\
\text { relevant reporting periods in order to achieve a holistic view of the dynamics of } \\
\text { economic, social and environmental activity }\end{array}$ \\
\hline Efficiency & $\begin{array}{l}\text { Reporting should be submitted promptly and clearly with the recommendations } \\
\text { aimed at improving the results of company business activity and serving as } \\
\text { operational control tool }\end{array}$ \\
\hline Creativity & $\begin{array}{l}\text { Knowledge is not limited to new information about the world, therefore, when } \\
\text { composing and reporting, use creative and non-standard approaches. }\end{array}$ \\
\hline Complexity & $\begin{array}{l}\text { Complexity provides a comprehensive study of causal interdependencies, a } \\
\text { coherent assessment of the input parameters of functional and structural } \\
\text { construction, their change and development concerning the investigated object in } \\
\text { space and time on the quantitative and qualitative features and output (effective) } \\
\text { parameters of this process. The report should include not only the key target } \\
\text { results, but also the indirect ones. The integrity of the system, which is } \\
\text { characterized by definite completeness, assumes separate reports from its } \\
\text { constituent elements. }\end{array}$ \\
\hline
\end{tabular}

Source: compiled by the authors

The financial and nonfinancial indicators presented in the companies integrated reporting can be generalized within the limits of certain types of economic activity, branches of the national economy and the country as a whole. Thus, the preconditions can be created for comparing the results of investment and innovation development of Ukraine with other countries achievements by classifying them in accordance with types of economic activity, branches of economy and other f eatures. 


\section{References}

Bezverkhyi, K. V. (2015). Socially-oriented reporting of the company. Accounting and audit. No. 2-3, 70-78.

Bezverkhyi, K. V. (2016). Integrated reporting enterprise: the economic essence of the concept.Scientific Bulletin of the National Academy of Statistics, Accounting and Auditing: Coll. of scientific works. No. 4, 43-58.

Butinets, T. A., Davydyuk, T. V., Zhigley, I. V., Zamula I. V. (2012). Development of the science of accounting and economic control: ensuring sustainable development of the Ukrainian economy: monograph. Zhytomyr: ZhDTU.

Dipiazza S. A., Eccles, R. J. (2003). The Future of Corporate Reporting: How to Regain Society's Confidence. Transl. from english by V. Ionov, Yu. Ezersky. Moscow: Alpina Publishers.

Evdokimov, V. V., Grityshen, D. O., Grishchenko, O. O., Barishnikova, O. M. (2013). (2013). International models of reporting on sustainable development: analysis of the current state: monograph. Zhytomyr: ZhDTU.

Evdokimov, V. V., Oliynyk, O. V., Grityshen, D. O., Grishchenko, O. O. (2013). Concept of management of economic safety of subjects of management in the context of the theory of sustainable development: monograph. Zhytomyr: ZhDTU.

Golov S. F. (2009). Current state and prospects of the accounting development in Ukraine: dissertation dissertation. ... doctor of economics sciences: 08.00.09. Kiev: KNEU.

Gritsyshen D. O. (2015). Accounting and analytical support for management of economic and environmental safety of enterprises: monograph. Zhytomyr: ZhDTU.

Integrated reporting. Avaliable at: http://ir.org.ru/attachments/article/13/Consultation-Draft-ofthe-InternationalIR Framework-Russian.pdf.

International Standard "Integrated Reporting". Avaliable at: http: // theiirc.org ISO 26000 - Social responsibility. Avaliable at: http://www.iso.org/iso/ru/home/ standards/iso26000.htm.

Law of Ukraine "About Accounting and Financial Reporting in Ukraine" of 16.07.99.No.996XIV with amendments and additions. Avaliable http://w1.c1.rada.gov.ua/pls/zweb2/webproc4_1?pf3511=62044

Petrenko, S. M., Bessarabov, V. O. (2015). Model of construction of socially-oriented accounting and reporting: organizational component. Vestnik of Perm University. Issue "Economics". No. 4 (27), 170-178.

Seven questions for the head of the company to have an answer Avaliable at: http://www.ey.com/Publication/vwLUAssets/Seven-things-CEOs-boards-should-ask-about-

reporting-RU/\$FILE/Seven-things-CEOs-boards-should-ask-about-reporting-RU.pdf

Shochina, A. N. (2006). Non-financial reports of companies operating in Russia: practice of social reporting development: analytical review. Moscow: RSPP.

Solovey, T. N. (2014). Formation of financial statements of a socially active firm: dissertation diss. ... candidate of economic sciences: 08.00.12. St. Petersburg.

Svirko, S. V., Baryshnikov, O. M. (2015). Sustainability reporting as a means of reflecting the state of the company's economic and environmental safety.Problems of the theory and methodology of accounting, control and analysis. Issue 3 (33), 309-325.

Zhigley, I. V. (2010). Accounting of socially responsible activity of business entities: necessity and guidelines for development: monograph. Zhytomyr: ZhDTU. 


\section{AUTHORS' TEAM \\ (in the alphabetical order)}

1. Berezina Olena

PhD (Economics), Professor,

Professorof the Finance Department,

Cherkasy State Technological University, Cherkasy, Ukraine

2. Boyko Angela

Doctor of Philosophy Sciencies, Professor,

Head of the Philosophy and Political Sciences Department,

Cherkasy State Technological University

3. Galchenko Volodimir

Doctor of Technical Sciences, Professor,

Professor of the Department of Computerized and Informatized

Technologies of Instrumentation,

Cherkasy State Technological University, Cherkasy, Ukraine

\section{Goncharenko Iryna}

Doctor of Sciences in State Management, Professor,

Head of the Finance Department,

Cherkasy State Technological University, Cherkasy, Ukraine

5. Grygor Oleg

PhD (State Management),Associate Professor,

Rector, Cherkasy State Technological University, Cherkasy, Ukraine

6. Izmaylov Yaroslav

PhD (Economics), Associate Professor,

Associate Professor of the International Economics Department,

Kryvyi Rih Economic Institute of Kyiv National Economic University named after Vadym Hetman, Kryvyi Rih, Ukraine

7. Kala

Prof. Universite Internationale Jean Paul II de Bafang, Cameroon

8. Khomenko Olena

PhD (Chemical Sciences), Professor,

Head of the Ecology Department,

Cherkasy State Technological University, Cherkasy, Ukraine

\section{Kolomytseva Olena}

Doctor of Economics Sciencies, Professor,
General and

scientific edition,

Chapter 1.3.; 2.4.;

3.2.

Pp. 36-42; 74-83;

105-114.

Chapter 3.1.

Pp. 89-104.

Chapter 5.1.

Pp. 160-171.

Chapter 1.3.

Pp. 36-42.

Chapter 3.1.

Pp. 89-104.

Chapter 5.4.

Pp. 190-203.

Chapter 5.2.

Pp. 171-181.

Chapter 5.3.

Pp. 181-190.
Chapter 4.1.

Pp. 129-138. 
Head of the Economic Cybernetics and Marketing Department,

Cherkasy State Technological University, Cherkasy, Ukraine

10. Kovalchuk Yanina

PhD (Economics), Associate Professor of the Economics and

Chapter 2.5.

Enterpreneurship Department,

Pp. 83-88.

Cherkasy State Technological University, Cherkasy, Ukraine

11. Kulishov Volodimir

Doctor of Pedagogical Sciencies, PhD (Economics),

Chapter 2.3.

Pp. 66-73.

Honored Educator of Ukraine,

Professor of the Polonia University in Czestochowa, Poland,

Professor of the International Economics Department,

Kryvyi Rih Economic Institute of Kyiv National Economic University named after Vadym Hetman, Kryvyi Rih, Ukraine

12. Krynski Andrzej

Professor, PhD, Polonia University in Czestochowa, Czestochowa, Poland

13. Kulyk Yuliia

Chapter 4.1.

Lecturer of the Economic Cybernetics and Marketing Department,

Cherkasy State Technological University, Cherkasy, Ukraine

Chapter 2.3.

Pp. 66-73.

Pp. 129-138.

14. Kunchenko-Harchenko Valentina

Chapter 3.4.

Doctor of Technical Sciences, Professor,

Pp. 123-128.

Head of the Informatic, Information Security

and Documental Sciences Department,

Cherkasy State Technological University, Cherkasy, Ukraine

15. Leshchenko Marina

PhD (Economics), Senior Lecturer

of the International Economics and Business Department,

Chapter 3.3.

Cherkasy State Technological University, Cherkasy, Ukraine

16. Makarenko Yuliia

Chapter 1.4.

PhD (Philology), Associate Professor,

Associate Professor of the Applied Linguistic Department,

Pp. 42-51.

Cherkasy State Technological University, Cherkasy, Ukraine

17. Maksymova Iryna

Chapter 5.2.

PhD (Economics),

Pp. 171-181.

Associate Professor of the International Economics Department,

Kryvyi Rih Economic Institute of Kyiv National Economic University named after Vadym Hetman, Kryvyi Rih, Ukraine

18. Marushchak Daria

Chapter 2.1.

PhD (Economics), Senior Lecturer

Pp. 52-58. 
of the International Economics and Business Department,

Cherkasy State Technological University, Cherkasy, Ukraine

19. Pasenko Vladislav

PhD (Economics), Associate Professor, Associate Professorof the

International Economics and Business Department, Cherkasy State

Technological University, Cherkasy, Ukraine

20. Petkova Lesya

Doctor of Economics Sciencies, Professor,

Head of the International Economics and Business Department,

Cherkasy State Technological University, Cherkasy, Ukraine

Chapter 2.1.

Pp. 52-58.

General and

scientific edition,

Chapter 2.2.

Pp. 58-70.

21. Pikalov Yuriy

Chapter 4.2.

Graduate student,

Cherkasy State Technological University, Cherkasy, Ukraine

Pp. 138-141.

22. Puriy Hanna

PhD (Economics), Associate Professor of the International

Chapter 5.2.

Pp. 171-181.

Economics Department,

Kryvyi Rih Economic Institute of Kyiv National Economic University

named after Vadym Hetman, Kryvyi Rih, Ukraine

23. Ryabokon Michael

Chapter 4.2.

Graduate student,

Cherkasy State Technological University, Cherkasy, Ukraine

Pp. 138-141.

24. Shatalov Yevgeniy

Chapter 2.3.

Assistant of the International Economics Department,

Kryvyi Rih Economic Institute of Kyiv National Economic University named after Vadym Hetman, Kryvyi Rih, Ukraine

25. Slyusarenko Kateryna

Chapter 5.4.

PhD (Economics), Associate Professor,

Pp. 190-203.

Head of the International Economics Department,

Kryvyi Rih Economic Institute of Kyiv National Economic University named after Vadym Hetman, Kryvyi Rih, Ukraine

26. Tkachenko Yuliia

PhD (Economics), Associate Professor,

Associate Professorof the Finance Department,

Cherkasy State Technological University, Cherkasy, Ukraine

Chapter 1.1., 1.2.,

1.4., 2.5., 4.2.,

4.4., 4.5.

Pp. 10-36; 42-51;

83-88; 138-141;

148-159.

27. Trembovetskaya Ruslana

PhD (Technical Science), Associate Professor

Chapter 5.1.

Pp. 160-171. 
and Informatized Technologies of Instrumentation,

Cherkasy State Technological University, Cherkasy, Ukraine

28. Tychkov Volodimir

PhD (Technical Science), Senior Lecturer of the Department of

Chapter 5.1.

Computerized and Informatized Technologies of Instrumentation,

Pp. 160-171.

Cherkasy State Technological University, Cherkasy, Ukraine

29. Vasylchuk Iryna

Doctor of Economics Sciencies, Associate Professor,

Professor of the Finance, Banking and Insuarance Department,

Kryvyi Rih Economic Institute of Kyiv National Economic University

named after Vadym Hetman, Kryvyi Rih, Ukraine

30. Vdovychenko Yuriy

PhD (Economics), Associate Professor,

Chapter 3.3.

Associate Professor of the International Economics

Pp. 114-123.

and Business Department,

Cherkasy State Technological University, Cherkasy, Ukraine

31. Vedeneieiv Vitaliy

PhD (Political Science), Associate Professor of the International

Economics Department, Kryvyi Rih Economic Institute of Kyiv

National Economic University

named after Vadym Hetman, Kryvyi Rih, Ukraine

32. Yegorova Iryna

PhD (Economics), Associate Professor

Associate Professor of the International Economics Department,

Kryvyi Rih Economic Institute of Kyiv National Economic University named after Vadym Hetman, Kryvyi Rih, Ukraine

33. Zagoruyko Nelli

Chapter 5.3.

PhD (Biological Sciences), Associate Professor,

Chapter 2.3.

Pp. 66-73.

Chapter 5.2.

Pp. 171-181.

Associate Professor of the Ecology Department,

Pp. 181-190.

Cherkasy State Technological University, Cherkasy, Ukraine

34. Jowita Ziolek-Barczak

MA, Polonia University in Czestochowa, Poland

Chapter 5.4.

Pp.190-203. 
Scientific publication

\section{GLOBAL PARTNERSHIP FOR LOCAL SUSTAINABLE DEVELOPMENT: MODERN TRENDS AND BEST PRACTICES}

The general and scientific editorship by

Dr., Professor L. O. Petkova

Ph.D., Professor O. Yu. Berezina

Ph.D., Professor Andrzej Kryński

Circulation 300. Order № 547.

Signed for print June $25^{\text {th }}, 2018$.

Format $60 \times 84 / 16$. Pr. sh. 15,2. Ac. sh. 15,4. 